\title{
Het onmiddellijkheidsbeginsel in het Nederlandse strafproces
}

Citation for published version (APA):

Garé, D. M. H. R. (1994). Het onmiddellijkheidsbeginsel in het Nederlandse strafproces. [Doctoral Thesis, Maastricht University]. Gouda Quint. https://doi.org/10.26481/dis.19941006dg

Document status and date:

Published: 01/01/1994

DOI:

$10.26481 /$ dis. $19941006 \mathrm{dg}$

Document Version:

Publisher's PDF, also known as Version of record

\section{Please check the document version of this publication:}

- A submitted manuscript is the version of the article upon submission and before peer-review. There can be important differences between the submitted version and the official published version of record.

People interested in the research are advised to contact the author for the final version of the publication, or visit the DOI to the publisher's website.

- The final author version and the galley proof are versions of the publication after peer review.

- The final published version features the final layout of the paper including the volume, issue and page numbers.

Link to publication

\footnotetext{
General rights rights.

- You may freely distribute the URL identifying the publication in the public portal. please follow below link for the End User Agreement:

www.umlib.nl/taverne-license

Take down policy

If you believe that this document breaches copyright please contact us at:

repository@maastrichtuniversity.nl

providing details and we will investigate your claim.
}

Copyright and moral rights for the publications made accessible in the public portal are retained by the authors and/or other copyright owners and it is a condition of accessing publications that users recognise and abide by the legal requirements associated with these

- Users may download and print one copy of any publication from the public portal for the purpose of private study or research.

- You may not further distribute the material or use it for any profit-making activity or commercial gain

If the publication is distributed under the terms of Article $25 \mathrm{fa}$ of the Dutch Copyright Act, indicated by the "Taverne" license above, 
Het onmiddellijkheidsbeginsel in het Nederlandse strafproces 



\section{Het onmiddellijkheidsbeginsel in het Nederlandse strafproces}

\section{PROEFSCHRIFT}

ter verkrijging van de graad van doctor

aan de Rijksuniversiteit Limburg te Maastricht, op gezag van de Rector Magnificus, Prof.dr. H. Philipsen, volgens het besluit van het College van Dekanen, in het openbaar te verdedigen op donderdag 6 oktober 1994 om 16.00 uur

door

Dorothea Marcella Hubertina Rosa Garé

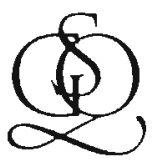

Gouda Quint bv

(S. Gouda Quint - D. Brouwer en Zoon)

Arnhem 
Promotoren:

Prof.mr. G.P.M.F. Mols

Prof.mr. Th.A. de Roos

Beoordelingscommissie:

Prof.mr. M.G. Faure (voorzitter)

Dr. P.L. Bal

Dr. J.F. Nijboer (Rijksuniversiteit Leiden)

Prof.mr. S.A.M. Stolwijk (Universiteit van Amsterdam) 


\section{Voorwoord}

Het werken aan een dissertatie is een eenzame aangelegenheid. Meer dan eens heb ik gedacht: kon ik opnieuw beginnen, dan zou ik nog niet zo zeker weten of ik me wederom zou wagen aan het schrijven van een proefschrift. Toch ben ik altijd blij geweest dat opnieuw beginnen niet mogelijk was. Achteraf valt alles natuurlijk geweldig mee. Je bent al heel snel de twijfel vergeten die bezit van je nam op momenten dat het weer eens tegen zat. Maar, hoewel ik nooit écht heb getwijfeld, is het mooi om te zien dat het er uiteindelijk toch van komt. Dat geeft je moed voor de toekomst.

Er is een aantal mensen die ik graag zou willen bedanken voor de steun die ik van hen kreeg bij het schrijven van dit boek.

Allereerst zijn dat mijn promotores, Prof.mr. G.P.M.F. Mols en Prof.mr. Th.A. de Roos.

Vervolgens zijn dat de leden van de leescommissie: Prof.mr. M.G. Faure (voorzitter), Dr. P.L. Bal, Dr. J.F. Nijboer en Prof.mr. S.A.M. Stolwijk.

Dan zijn er nog de vele collega's van strafrecht. De sfeer binnen de vakgroep is prima, hetgeen zeker heeft bijgedragen aan de succesvolle afronding van dit werk. Josta Mommertz en vooral Margot de Boer, beiden werkzaam als secretaresse bij de vakgroep strafrecht, verdienen bovendien lof voor de zorg die zij hebben besteed aan het "camera-ready" maken van het manuscript.

Er is één collega die hier aparte vermelding verdient. Dat is Jürgen Wöretshofer. Jürgen, zonder jouw bemoeienissen was dit proefschrift nooit geworden tot wat het nu is. Vanaf het moment dat er een eerste versie lag, heb je kritisch meegelezen en vooral meegedacht. We hebben hele middagen en avonden gediscussieerd. Je hebt steeds geïnformeerd hoe het ermee stond en daarmee mijn werktempo hoog gehouden. Je stond steeds klaar, wanneer ik dacht vast te zitten of anderszins de moed dreigde te verliezen. Je hebt me enorm gestimuleerd en gesteund en ik ben je daarvoor buitengewoon dankbaar.

Aparte vermelding verdient ook Kees-Jan. Samenleven met iemand die een proefschrift schrijft en van het werk geen afstand kan nemen, is niet altijd even leuk.

Lieve, Kees-Jan, bedankt voor je geduld.

Rest mij alleen nog mijn ouders en grootouders te bedanken voor de constante belangstelling die zij hebben getoond voor de vorderingen in mijn werk.

Dorothé Garé 


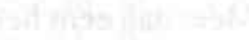

at hithina it

- 


\section{Inhoudsopgave}

Lijst van afkortingen

\section{Inleiding}

Hoofdstuk 1 De historische ontwikkeling van ons strafproces in het licht van het onmiddellijkheidsbeginsel

Het initiatief tot strafvervolging en het verloop van het proces

2.2 Bewijsvoering bij ontkenning van de aanklacht

Het strafproces ten tijde van de Frankische periode $( \pm 500-1000)$ 
De Constitutio Criminalis Carolina en de verdere ontwikkeling van het Duitse strafproces

6.2.2 Kennis van de feiten uit derde hand

\section{De C'riminele Ordonnantiën van Philips II (1570) en de} verdere ontwikkeling van het Nederlandse strafproces tot aan de Frailse uverheersing (1810)

De Ordonnantie op den stijl van procedeeren in criminele zaken

Het initiatief tot vervolgen

Bewijsvoering en de positie van de beklaagde

De ontwikkeling van het strafproces na de Criminele Ordonnantiën

7.4 Hervormingen

De invloed van de Code d'Instruction Criminelle op de strafvordering in Nederland 


\section{Hoofdstuk 2 Begripsbepaling van het onmiddellijkheidsbeginsel}

De verhouding tussen de onmiddellijkheid en de mondelinge procesvoering

3.1 De opvatting van Von Feuerbach over het beginsel van de mondelinge procesvoering

3.2 Het belang en de betekenis van het beginsel van de mondelinge procesvoering volgens Mittermaier

3.3 Het onderscheid tussen het beginsel van de mondelinge procesvoering en het onmiddellijkheidsheginsel volgens Maas

3.4 De betekenis en inhoud van het beginsel der mondelinge procesvoering en de relatie met het onmiddellijkheidsbeginsel volgens Geppert

Opvattingen in de Duitse literatuur over de inhoud van het onmiddellijkheidsbeginsel

4.1 De opvatting van Maas over de inhoud van het onmiddellijkheidsbeginsel

4.2 De opvatting van Löhr over de inhoud van het onmiddellijkheidsbeginsel

De opvatting van Geppert over de inhoud van het onmiddellijkheidsbeginsel 
4.3.2.1 De controleerbaarheid van origineel bewijs 59

4.3.2.2 De controleerbaarheid van gereproduceerd bewijs 60

4.3.2.2.1 De reproduktie van 'persoonlijke bewijsmiddelen' 60

4.3.2.2.2 De reproduktie van 'zakelijke bewijsmiddelen' 62

4.3.3 Conclusie 62

4.4 Aspecten van het onmiddellijkheidsbeginsel: een tussenstand 63

5 Opvattingen in de Nederlandse literatuur over de inhoud van het onmiddellijkheidsbeginsel

5.1 De beschouwing van Simons over het onmiddellijkheidsbeginsel

5.2 De opvatting van Stolwijk over het onmiddellijkheidsbeginsel

5..3 Strekking en belang van het onmiddellijkheidsbeginsel volgens F.F. Langemeijer

$5.4 \quad$ Inhoud van het onmiddellijkheidsbeginsel volgens Nijboer

5.5 Belang van het onmiddellijkheidsbeginsel volgens Reijntjes

Gebruik van stukken uit het vooronderzoek en controleerbaarheid

6.3 Controleerbaarheid van het bewijs en de niet meewerkende verdachte

6.4 Definitie van het onmiddellijkheidsbeginsel

6.5 Het onmiddellijkheidsbeginsel als bewijsbeginsel of als structuurbeginsel

Conclusie

Hoofdstuk 3 Het onmiddellijkheidsbeginsel in ons strafproces sinds 1926

Het onmiddelijkheidsheginsel in de opzet van ons huidig strafproces

2.4 De mondelinge dan wel schriftelijke getuigenverklaring van horen zeggen 
3.1 Overwegingen ten aanzien van de mondelinge getuigenverklaring van horen zeggen

3.2 Overwegingen ten aanzien van de schriftelijke getuigenverklaring van horen zeggen

De opvattingen van Taverne over de verklaring van horen zeggen

Gehoorsindruk is zelf waargenomen of ondervonden

5.3 Praktische onmogelijkheid van het negatief wettelijke bewijsstelsel

Hoofdstuk 4 Het onmiddellijkheidsbeginsel en het recht op een 'fair trial'

Het recht op het horen van getuigen à charge als onderdeel van het recht op een 'fair trial' 
3.2.1 Gereproduceerde stukken van overtuiging 114

$\begin{array}{lll}\text { 3.2.2 Gereproduceerde getuigenverklaringen } & 115\end{array}$

3.2.2.1 Dubbele voorwaarde 116

$\begin{array}{lll}3.2 .3 & \text { Conclusie } & 119\end{array}$

3.2.4 Uitzonderingen op de hoofdregel mits de verdachte een adequate en gepaste gelegenheid heeft gehad de getuige te (doen) ondervragen tijdens het vooronderzoek

3.2.4.1 Onbekendheid met de identiteit van de getuige 121

$\begin{array}{lll}3.2 .4 .1 .1 & \text { Compensatie } & 123\end{array}$

$\begin{array}{lll}\text { 3.2.4.1.2 Conclusie } & 125\end{array}$

3.2.4.2 Aanwezigheid van de raadsman 125

3.2.4.3 De rol van het bewijs voor de bewezenverklaring 126

3.2.4.4 Conclusie 128

3.3 Ontvankelijkheid van de klager en verdeling van verantwoordelijkheden 129

$\begin{array}{lll}\text { 3.3.1 Conclusie } & 131\end{array}$

$4 \quad$ Onmiddellijkheidsbeginsel en een 'fair trial'

132

5 De invloed van de Europese jurisprudentie op het onderzoek ter terechtzitting

5.1 Medeverantwoordelijkheid van de verdachte 135

$5.2 \quad$ Onduidelijkheid over de hardheid van de hoofdregel 137

$\begin{array}{lll}5.3 & & 139\end{array}$

$\begin{array}{lll}5.4 & 139\end{array}$

$6 \quad$ Samenvatting

Hoofdstuk 5 Enkele plannen tot partiële herziening van het Wetboek van Strafvordering getoetst aan het onmiddellijkheidsbeginsel

$2.1 \quad$ Het rapport van de Commissie Moons

2.1.1 Argumenten van de Commissie Moons voor het behoud van het gerechtelijk vooronderzoek

2.1.2 Bedreiging van het onmiddellijkheidsbeginsel

2.1.2.1 Contradictoir vooronderzoek versus onmiddellijk eindonderzoek 
2.1.4 Rol van de politie in het voorbereidend onderzoek 152

2.1.5 Conclusie 153

$2.2 \quad$ Het wetsvoorstel betreffende de herziening van het gerechtelijk vooronderzoek

2.2.1 De wijziging van de regeling betreffende het verhoor van getuigen in het gerechtelijk vooronderzoek

3.2 De Wet Getuigenbescherming getoetst aan het recht op een 'fair trial'

3.2.1 De toelaatbaarheid van anoniem getuigenbijwijs

De rol van het bewijs voor de bewezenverklaring

3.3 De Wet Getuigenbescherming en het onmiddellijkheidsbeginsel

3.3.1 De belangenafweging door de Minister van Justitie $\quad 167$

$\begin{array}{lll}3.3 .2 & \text { Verkeerde methode } & 167\end{array}$

$\begin{array}{lll}\text { 3.3.3 Ongewenste gevolgen } & 169\end{array}$

$\begin{array}{lll}3.4 & \text { Conclusie } & 170\end{array}$

De verkorte procedure voor bekennende verdachten

4.2 De argumenten om te komen tot een verkorte procedure een 'fair trial'

4.4 De vereenvoudigde procedure en het onmiddellijkheidsbeginsel

4.5 Conclusie

Samenvatting en conclusie

\section{Conclusie}

Het onmiddellijkheidsbeginsel in ons strafproces sinds 1926 
De opvatting van de huidige wetgever over het belang van het onmiddellijkheidsbeginsel voor een deugdelijke strafrechtspleging en de waardering daarvan

Conclusion

Schlußfolgerung

Lijst van aangehaalde literatuur

Aangehaalde jurisprudentie

Curriculum vitae 


\section{Lijst van afkortingen}

AA

aant.

A-G

afl.

APB

$\operatorname{art}(t)$.

a.w.

$\mathrm{CCC}$

$\mathrm{CIC}$

CID

c.s.

D\&D

ECRM

EHRM

EVRM

e.v.

GVO/gvo

HR

Hrsgg.

HTK

IRT

jo.

m.n.

MRT

MvT

NJ

NJB

NJCM

NJV

nr.

ORO

o.r.v.
Ars Aequi

aantekening

advocaat-generaal

aflevering

Algemeen Politieblad

artikel(en)

aangehaald werk

Constitutio Criminalis Carolina

Code d'Instruction Criminelle

Criminele informatie dienst

cum suis

Delikt en Delinkwent

Eurpese Commissie voor de rechten van de mens

Europees Hof voor de rechten van de mens

Europees Verdrag tot bescherming van de rechten van de mens en de fundamentele vrijheden

en verder

Gerechtelijk vooronderzoek

Hoge Raad der Nederlanden

Herausgeber

Handelingen Tweede Kamer der Staten-Generaal

Interregionaal team

juncto

met name

Militair Rechtelijk Tijdschrift

Memorie van Toelichting

Nederlandse Jurisprudentie

Nederlands Juristenblad

Nederlands Juristen Comité voor de Mensenrechten

Nederlandse Juristenvereniging

nummer

Oorspronkelijk Regeringsontwerp

onder redactie van 
OvJ officier van justitie

p. pagina('s)

$\mathrm{R}(-) \mathrm{C}$ rechter-commissaris

resp. respectievelijk

RM Rechtsgeleerd Magazijn

r.o. rechtsoverweging

Stb Staatsblad

StPo Strafprozeßordnung

suppl. supplement

TK

Tweede Kamer der Staten-Generaal

$\mathrm{t} / \mathrm{m}$

tot en met

TvS

Tijdschrift voor Strafrecht

vol.

volume

W

Weekblad van het Recht

WODC Wetenschappelijk onderzoek en documentatie centrum $(\mathrm{Wv}) \mathrm{Sv}$ Wetboek van Strafvordering

z.j. zonder jaartal 
gebaseerd op het proces-verbaal opgemaakt door de undercover-agent - het betreft hier een schriftelijke getuigenverklaring - en de tapjournaals van de telefoongesprekken van deze met de verdachte. Noch in eerste aanleg, noch in hoger beroep werd de undercover-agent, die de verdachte vijf maal had ontmoet, ter zitting gedagvaard omdat zijn anonimiteit, met het oog op zijn mogelijk nieuwe inzetbaarheid als infiltrant, gewaarborgd diende te worden. Het Hof uordeelt:

"The court tinds that the present case can be distinguished from the Kostovski v. the Netherlands and the Windisch v. Austria cases, where the impugned convictions were hased on stittements made by anonymous witnesses. In this case the person in question was a sworn pulice officer whose function was known to the investigating judge. Moreover, the applicant knew the said agent, if not by his real identity, at least by his physical appearance, as a result of having met him on five occasions. However, neither the investigating judge nor the trial courts were able or willing to hear Toni as a witness and carry out a confrontation which would enable Toni's statements to be contrasted with Mr Lüdi's allegations; moreover, neither Mr I.üdi nor his counsel had at any time during the proceedings an opportunity to question him and cast doubt on his credibility. Yet it would have been possible to do this in a way which took into account the legitimate interest of the police authorities in a drug trafficking case in preventing the anonymity of their agent, so that they could protect him and also make use of him again in the future. In short, the rights of the defence were restricted to such an extent that the applicant did not have a fair trial. ${ }^{m+1}$

Deze undercover-agent kon niet worden beschouwd als een anonieme getuige in de strikte zin de's woords. Terwijl in de Kostuvski en de Windisch zaak de bekendheid mel de identiteit van de getuigen noodzakelijke informatie vormde om de getuige adequaat te kunnen ondervragen, was in dit geval de bekendheid met de wáre identiteit van de getuige daartoe niet onontbeerlijk. Omdat de verdachte de undercoveragent reeds kende van gezicht, had hij ook kunnen controleren of hij met de juiste persoon geconfronteerd werd en had hij hem gericht kunnen (doen) ondervragen. $\mathrm{Nu}$ hem daartoe de gelegenheid niet was geboden, moest worden vastgesteld dat de verdachte geen 'fair trial' ten deel was gevallen'.

Lüdi zaak, EHRM 15 juni 1992, Series A, vol. 238 „\$\$ 49 en 50 .

Zie ook L.C.M. Meijers, Over Lüdi tegen Zwitserland, EHRM 15 juni 1992, D\&D 1994, p. 276 en 277 , die uit deze zaak alleidt dat "verklaringen van een anonieme politiefunctionaris" bij de bewijsvoering een belangrijk gewicht in de schaal mogen leggen, mits het recht van de verdachte op tegenspraak in enige fase van de procedure is verwezenlijkt. Voor dit laatste is niet noodzakelijk dat regenover de verdediging de anonimiteit van de getuige (in de ruime zin van het woord) wordt opgeheven." Het lijkt erop dat Meijers en ik het met elkaar eens zijn, maar zeker is dit niet, omdat onduidelijk is wat Meijers bedoeld met 'anonimiteit in ruime zin'. Bovendien denk ik dat in het kader van de Lüdi zaak beter niet kan worden gesproken van "verklaringen van een anonieme politiefunctionaris". De crux van de zaak is dat verklaringen moeten zijn terug te voeren tot de corspronkelijke zegsman zodat de verdediging deze oorspronkelijke zegsman daarover gericht kan ondervragen. Slechts in die zin is de identiteit van de getuige "necessary information" (vgl. de Kostovski en Windisch zaak). Een anonieme getuigenverklaring is nu juist een verklaring die 


\section{Inleiding}

Degenen in Nederland, die uit nieuwsgierigheid of betrokkenheid ooit de gang naar het gerechtsgebouw maakten om aanwezig te zijn bij de behandeling van een strafzaak, met in het achterhoofd de beelden van bijvoorbeeld een televisieserie als L.A. Law, zullen waarschijnlijk teleurgesteld zijn in hun verwachtingen. Het onderzoek ter terechtzitting in een strafzaak kenmerkt zich in het algemeen door een gebrek aan actie. Getuigen en deskundigen worden slechts bij uitzondering ter zitting gehoord. Men krijgt de indruk dat de behandeling van de zaak ter zitting niet meer is dan een bespreking van de stukken uit het vooronderzoek door de rechter al dan niet in aanwezigheid van de verdachte.

Deze - inmiddels traditionele - gang van (straf)zaken is nooit onomstreden geweest, maar de laatste jaren is de roep om meer aandacht voor het onmiddellijkheidsbeginsel luider dan ooit. In de literatuur worden steeds vaker vraagtekens gezet bij de opvatting dat onze wijze van inrichting van het onderzoek ter terechtzitting - en met name het gebrek aan het accusatoire gehalte daarvan - in overeenstemming is met de minimumeisen die art. 6 EVRM stelt aan een 'fair trial'.

\section{Keuze van het onderwerp}

Deze studie gaat over het onmiddellijkheidsheginsel in het Nederlandse strafproces. De keuze voor dit onderwerp werd mede ingegeven door de groeiende belangstelling die er in de strafrechtswetenschap voor dit beginsel bestaat'. Wat daarbij opvalt, is dat in de recente literatuur de betekenis van dit beginsel als min of meer bekend wordt verondersteld ${ }^{2}$. De vraag is of dat wel terecht is. Er zijn in de Nederlandse

1 Zie ook C.F. Mulder, Het onmiddelijkheidsbeginsel en de structuur van het vooronderzoek in het strafprocesrecht van Denemarken en Noorwegen, D\&D 1992, p. 1029.

2 Zie bijvoorbecld Ties Prakken, Naar een tweesporig strafproces?, NJB 1992, p. 12\%, wanneer zij schrijft: "Het is inmiddels genoegzaam bekend dat het onmiddellijkhcidsbeginsel, vooral neergelegd in de artt. 338, 340, 348 en 350 Strafvordering, in Straatsburg serieuzer wordt genomen dan in Den Haag, waar de hoge raad het, zoals we weten, een jaar na invoering van het huidige Wetbrek van strafvordering in het beruchte 'de auditu' arrest meteen weer afschafte, en waar thans de Commissic Moons zich er kennelijk nogal huiverig voor betoont". Zie ook: G.J.M. Corstens, Getuigen op de rilling, D\&D 1992, p. 210 en 211. 
literatuur aan dit onderwerp geen diepgaande beschouwingen gewijd. Wel heeft Mols in zijn oratie, die het onmiddellijkheidsbeginsel tot onderwerp had, een voorschot genomen op en een prikkel gegeven tot een meer fundamentele verhandeling over dit beginsel ${ }^{3}$.

\section{Probleemstelling en opzet van het onderzoek}

De centrale vraag van dit proefschrift luidt: "Wat is de betekenis en ratio van het onmiddellijkheidsbeginsel en welke plaats komt dit beginsel toe in het Nederlandse strafproces?". Met name op het tweede deel van deze vraag heb ik een antwoord gezocht dat zowel van beschrijvende als normatieve aard is. De weergave van dat antwoord valt uiteen in een vijftal hoofdstukken.

Allereerst heb ik onderzocht waar het onmiddellijkheidsbeginsel vandaan komt. Daarover gaat hoofdstuk én. De hier gevonden informatie is noodzakelijk voor een juiste begripsbepaling van het onmiddellijkheidsbeginsel, het onderwerp van hoofdstuk twee. Voortbordurend op de inzichten uit de historie van het strafproces en aan de hand van de vele opvattingen die er in de loop der tijd in de literatuur over de betekenis en ratio van het onmiddellijkheidsbeginsel zijn geventileerd, heb ik een weg gezocht naar een eigen begripsbepaling van dit beginsel. Daarbij heb ik naast Nederlandse veel Duitse literatuur geraadpleegd, omdat in Duitsland - anders dan in ons land en in de andere ons omringende landen, zoals België en Frankrijk van oudsher veel aan theorievorming betreffende het onmiddellijkheidsbeginsel is gedaan. Aangezien Duitsland net als Nederland van oudsher een inquisitoire stijl van procederen kent, biedt deze Duitse theorievorming bruikbare inzichten in de inhoud en ratio van het onmiddellijkheidsbeginsel. Hoofdstuk drie gaat over de vraag hoe het onmiddellijkheidsbeginsel tot uitdrukking kwam in de opzet van ons huidige Wethrek van Strafvordering. Tevens wordt in dit hoofdstuk gezocht naar de oorzaken van de verwaarlozing van dit beginsel in ons huidige strafproces. In het vierde hoofdstuk heb ik onderzocht wat de relatie is tussen het recht van iedere verdachte op een 'fair trial' en het onmiddellijkheidsbeginsel. Het vijfde en laatste hoofdstuk ten slotte poogt een antwoord te geven op de vraag hoe onze huidige wetgever denkt over het belang van het onmiddellijkheidsbeginsel voor een goed ingericht onderzoek ter terechtzitting. Het geheel wordt afgesloten met een conclusie.

3 Zic G.P.M.F. Mols, Staande de zitting, Een beschouwing over het onmiddelijkheidsbeginsel, Amhem 1989. 


\section{De historische ontwikkeling van ons strafproces tot 1926 in het licht van het onmiddellijkheidsbeginsel}

\section{Inleiding}

In dit hoofdstuk wordt op zoek gegaan naar de oorsprong van het onmiddellijkheidsbeginsel. Dit onderzoek heeft tot doel een beter begrip te krijgen van de ratio en de betekenis van het onmiddellijkheidsbeginsel. In grote lijnen wordt de ontwikkeling van het strafproces in beeld gebracht. Die ontwikkeling kan worden gezien als de ontwikkeling van een accusatoir naar een inquisitoir strafproces. In zijn proefschrift getiteld: 'Bijdrage tot de kennis der historische ontwikkeling van het accusatoire tot het inquisitoire strafproces' onderscheidt Drenth drie criteria aan de hand waarvan deze ontwikkeling kan worden beschreven. Deze criteria zijn allereerst de vervolging en bestraffing van staatswege, ten tweede de positie van de verdachte in het strafproces en ten derde het onderzoek naar de materiële waarheid'. In navolging van Drenth besteed ik met name aandacht aan deze drie aspecten, omdat het ontstaan van het onmiddellijkheidsbeginsel ten nauwste met de ontwikkeling van die aspecten samenhangt.

Tegen het licht van het geschetste kader wordt begonnen met een beschrijving van het Germaanse strafproces te beschrijven vanaf zijn eerste verschijningsvorm tot aan zijn gedaante in de tijd dat West-Europa onderworpen was aan de heerschappij van de Frankische vorsten. Vervolgens schets ik kort de ontwikkeling van het Canonieke strafproces. Dit strafproces was aanvankelijk alleen van toepassing op de clerus en bestond naast en los van het wereldlijke strafproces. Toch wordt ook de ontwikkeling daarvan weergegeven omdat dit strafproces een blijvende en steeds groter wordende invloed heeft uitgeoefend op het wereldlijke strafproces.

Verder wordt globaal weergegeven hoe het strafproces, gelet op de bovengenoemde criteria, eruit zag gedurende de middeleeuwen. Deze schets is niet eenvoudig omdat onze contreien in die tijd als gevolg van het leenstelsel, het ontstaan van landsheerlijkheden, de opkomst van de steden en de verzelfstandiging van de kerkelijke macht, waren opgedeeld in talloze rechtskringen. ledere rechtskring kende zijn eigen recht en gewoonten.

1 J.H. Drenth, Bijdrage tot de kennis der historische ontwikkeling van het accusatoire tot het inquisitoire strafproces, Amsterdam 1939, p. 9 1/m 18. 
Tot aan de late middeleeuwen lopen de ontwikkelingen van het strafproces in de Nederlandse en Duitse contreien parallel; rond die tijd treedt er een divergentie op. Het opkomende codificatiestreven leidt er toe dat in 1532 de Constitutio Criminalis Carolina tot stand komt, die echter vooral in de Duitse gebieden gelding heeft gehad. Omdat dit met het oog op het ontstaan van het onmiddellijkheidsbeginsel van belang is, volg ik eerst de ontwikkeling van het 'Duitse' strafproces vanaf de totstandkoming van deze regeling tot aan de Duitse hervormingsbeweging van de 19 e eeuw.

Daarna wordt de draad weer opgepakt en keer ik terug naar de ontwikkeling van het 'Nederlandse' strafproces vanaf de late middeleeuwen. Achtereenvolgens komen in vogelvlucht de Criminele Ordonnantiën van Philips II (1570), de Bataafse omwenteling en de invoering van de Code d'Instruction Criminelle ten tijde van de Franse overheersing aan de orde. Ik sluit dit hoofdstuk af met een beschrijving van de totstandkoming van het eerste nationale Wetboek van Strafvordering 1838.

\section{Het Germaanse strafproces}

De Germaanse periode kan voor wat betreft de noordelijke Nederlanden gesitueerd worden in het voor-middeleeuwse tijdperk tot aan omstreeks 800 toen deze streken door Karel de Grote, bij het Karolingische imperium werden ingelijfd ${ }^{2}$.

De Germanen waren oorspronkelijk georganiseerd in stammen, die in sommige gevallen plaatsgebonden waren. Het strafproces is in deze tijden nog moeilijk te onderscheiden van het uitoefenen van bestuur. De stam werd bestuurd door de volksvergadering, het 'ding' oftewel 'mallus' genoemd, dat onder leiding stond van een rechter (in oude zin). ${ }^{3}$. Deze 'rechter' wees in het algemeen geen vonnis, maar presideerde de zitting, vorderde recht en droeg zo nodig zorg voor de tenuitvoerlegging van het vonnis. Aan de vaststelling van de inhoud van het vonnis nam hij in het algemeen geen deel's.

Waarschijnlijk ook reeds in de Germaanse tijd begon een op vaste tijden gehouden 'ding' met het afzetten van de dingplaatsen door het spannen van koorden, vandaar dat men later sprak van 'het spannen van de vierschaar". De leden van de stam ofwel dinggenoten waren verplicht om op het 'ding' te verschijnen.

2 Zie J.P.H. de Monté Verloren, J.E. Spruit, Hoofdlijnen uit de ontwikkeling der rechterlijke organisatie in de noordelijke Nederlanden tot de Bataafse omwenteling, Deventer 1982, zesde druk, p. 19.

3 J.P.H. de Monté Verloren, J.E. Spruit (1982), a.w., p. 20 en 21. Zie ook L.Ph.C. van den Bergh, Verhandeling over de oude wijze van Strafvordering, Leiden 1842, p. 3.

4 J.P.H. de Monté Verloren, J.E. Spruit (1982), a.w., p. 7.

5 Zie L.Ph.C. van den Bergh (1842), a.w., p. 11 t/m 13; J.P.H. de Monté Verloren, J.E. Spruit (1982), a.w., p. 22. 
De rechter opende de zitting. De regel gold: waar geen klager is, is geen rechter". De aanklager trad voor de rechter en formuleerde zijn aanklacht. Dan werd de aangeklaagde opgeroepen om voor de rechter te verschijnen ${ }^{7}$. Erkende hij hetgeen hem werd verweten, dan was elk verder onderzoek overbodig en kon onmiddellijk vonnis worden gewezen. Daartoe vorderde de 'rechter' van één of meer der dinggenoten een voorstel, dat vervolgens door de overige omstand werd goedgekeurd of afgekeurd'. Het 'ding' bracht bij acclamatie een collectieve stem uit: het ging niet om de stem van ieder der dinggenoten, maar om de stem van de gemeenschap, ook wel gemeente of rechtskring genoemd".

\subsection{Bewijsvoering bij ontkenning van de aanklacht}

Ontkende de aangeklaagde hetgeen hem werd verweten, dan was bewijslevering nodig. Bij de Friezen had aanvankelijk de klager niet het recht bewijs te leveren, maar mocht en moest de beschuldigde zijn onschuld aantonen ${ }^{10}$. Hij kon zich daarbij bedienen van de zuiveringseed. Soms werd van hem vereist dat hij zijn eed verzwaarde door middel van eedhelpers". De Germanen hechtten grote waarde aan de eed. Men beschouwde het als een voorwaardelijke zelfvervloeking: in geval van meineed zou de aangeroepen godheid wraak nemen en de leugenaar verderf brengen ${ }^{12}$. Oorspronkelijk waren de eedhelpers stamgenoten van de beschuldigde. Zij traden niet op als getuigen ${ }^{13}$. Zij verklaarden immers niet over wat zij hadden waargenomen.

6 L.Ph.C. van den Bergh (1842), a.w., p. 63; P. van Heijnsbergen, Bijdrage tot de geschiedenis van het bewijsrecht, In: Verspreide Opstellen, Amsterdam 1929, p. 231; J.H. Drenth (1939), a.w., p. 105; E. Schmidt, Einführung in der Geschichte der deutschen Strafrechispflege, Dritte Auflage, Göttingen 1965, p. 38.

7 Zie ook E. Schmidt (1965), a.w., p. 39: "Würde sich der Beklagle der Ladung versagen, so würde ihm die Friedloslegung als prozessuale Ungehorsamsfolge drohen."

8 Zie D. Simons, Beknopte handlciding tot het Wetboek van Strafwordering. Haarlem 1925, 7c druk, p. 3; J.P.H. de Monté Verloren, J.E. Spruit (1982), a.w., p. 22.

9 Zie ook L.Ph.C. van den Bergh (1842), a.w., p. 3, die in dit verband opmerkt dat de beslissing over een vrije burger alle vrije burgers aanging.

10 Zie S.J. Fockema Andreac, Het bewijs in strafzaken hier te lande in de middeleeuwen, TvS 1897 , p. 47 en P. van Heijnsbergen (1929), a.w., p. 234.

11 Zie L.Ph.C. van den Bergh (1842), a.w., p. 47: "Naar mate het onderwerp belangrijker was, moest. ook het aantal zwerenden grooter zijn." Zie ook P. van Heijnsbergen (1929), a.w., p. $234 \mathrm{t} / \mathrm{m} 237$ en E. Schmidt (1965), a.w., p. 40.

12 P. van Heijnsbergen (1929), a.w., p. 235. Zie ook P. Traest, Het bewijs in strafaken, Gent 1992, p. 24 en $411 / \mathrm{m} 43$.

13 Zie over het onderscheid tussen getuigen en eedhelpers uitgebreid: H. Zeller, Uber Zeugen und Eideshelfer im deutschen Recht, Berlijn 1898. Zie ook M. de Vrugt, Aengaende criminele saken, Deventer 1982, p. 5. 
Zij verschenen slechts voor de rechter om onder aanroeping van het heiligste de plechtige verzekering uit te spreken, dat zij geloofden in de onschuld van de aange$k^{k l a a g d e}{ }^{14}$. Een waarborg voor hun betrouwbaarheid werd gevonden in de omstandigheid, dat zij mede strafbaar waren wegens meineed als later bleek dat de beschuldigde een valse eed had afgelegd. De eedhelpers moesten bovendien te goeder naam bekend staan en meestal van dezelfde stand zijn als de beklaagde.

Het gebruik van de zuiveringseed heeft zich eeuwen lang kunnen handhaven, maar nam in de loop der middeleeuwen in betekenis af. Naarmate de aanklager meer bevoegd werd tot bewijslevering, in het bijzonder door middel van getuigen, kwam deze eed van onschuld minder voor. Werd in latere tijden van de zuiveringseed nog gebriik gemaakt - bijvorbeeld bij gebrek aan ander bewijs -, dan werden daarbij steeds minder eedhelpers vereist ${ }^{15}$.

Toch heeft oudtijds, ook bij de Friezen, het recht tot bewijslevering voor de klager in het geding nooit helemaal ontbroken. Het stond hem naar Germaanse en ook naar Friese rechten steeds vrij de beklaagde tot een gerechtelijk duel uit te dagen. Degene aan wie God de overwinning van dit duel schonk, moest men geloven ${ }^{16}$. De bevoegdheid van de aangeklaagde om zijn onschuld aan te tonen door middel van een eed werd hem ontnomen door de bereidverklaring van de klager om een tweekamp aan te gaan ${ }^{17}$. De procederende partijen namen niet altijd persoonlijk aan de tweekamp deel; het kwam voor dat men zich liet vertegenwoordigen ${ }^{18}$.

Later zijn er naast de tweekamp en de zuiveringseed ook andere godsoordelen in gebruik geweest. Zo bestond er bijvoorbeeld nog de gewijde broodproef, waarbij de beschuldigde een grote homp van een gewijd brood in een keer onbelemmerd moest doorslikken, om daarmee zijn onschuld aan te tonen. Bij de koudwaterproef werd degene die het moest ondergaan (de aangeklaagde of diens plaatsvervanger) op een voorgeschreven manier vastgebonden en in het water geworpen. Zonk hij en werd hij er ongedeerd uitgehaald, dan was hij onschuldig; bleef hij drijven, dan was hij schuldig. Bij de ketelvang diende de aangeklaagde zijn hand in gloeiend heet water te steken. Was de hand na drie dagen geheeld, dan had de aangeklaagde zijn onschuld bewezen. Dit oordeel lijkt op dat van het heet ijzer en dat van de gloeiende ploegscharen ${ }^{10}$.

14 Zic ook L.Ph.C. van den Bergh (1842), a.w., p. 46 en E. Schmidt (1\%5), a.w., p. 40.

15 Zie P. van Heijnsbergen (1929), a.w., p. $234 \mathrm{t} / \mathrm{m} 237$.

16 S.J. Fockema Andreac (1897), a.w., p. 49. Zie ook E. Schmidt (1'K5), a.w., p. 39: "Der Gedanke, daß dic Gottheit hinter ihnen steht, ja beim Zweikampf und Gottesurtcil durch ihren Ausgang gewissermaßen selbst entscheidend zu Worte kommt, verlciht diesen Bewcisformen ihre überreugende Kraft."

17 P. van Heijnsbergen (1929), a.w., p. 242.

18 Zie L.Ph.C. van den Bergh (1842), a.w., p. 97; P. van Heijnsbergen (1929), a.w., p. 242.

19 L.Ph.C. van den Bergh, (1842), a.w., p. 94 en 95. Zie voor een uitgebreidere beschrijving van deze godsoordelen: S.J. Fockema Andreae (1897), a.w., p. $49 \mathrm{t} / \mathrm{m}$ 59. Zie ook P. Traest (1992), a.w., p. 45 en 46. 


\section{Het strafproces ten tijde van de Frankische periode ( \pm 500-1000)}

De Frankische periode vangt aan doordat de Franken de macht verwierven over de andere Germaanse stammen (7e eeuw). Een figuur uit deze tijd, die in WestEuropa een lange geschiedenis beschoren zou zijn, is die van het ambt van de graaf. De taak van de graaf bestond in het uitoefenen van de rechterlijke bevoegdheid in zijn ambtsgebied namens de Frankische koningen ${ }^{20}$. Dit ambtsgebied werd aangeduid met de termen 'graafschap' of 'gouw'. In plaats van door de 'rechter', die door de dinggenoten gekozen werd, werd het gouwgeding derhalve nu geleid door een koninklijke ambtenaar. Dit betekende een uitbreiding van's konings macht; immers als ambtenaar presideerde de graaf het ding en vorderde hij recht, dat wil zeggen vonnis in naam van de koning'2. Iedere graaf hield regelmatig zijn 'placita', waarin tevens de rechtspleging werd uitgeoefend. De graaf zat voor aan het hoofd der 'ramchimburgi', of later 'schepenen' genoemd, die uit de meest gegoede ingezetenen gekozen werden en als oordelers 'te regt' zaten. De wijze van rechtspleging voor de graaf en ramchimburgi was bijna gelijk aan welke eertijds op het ding gevolgd werd. De graaf opende de vergadering met een aanspraak; hij hoorde alle klachten aan en vroeg vervolgens de ramchimburgi om hun oordeel ${ }^{22}$.

\subsection{Bewijsvoering}

Bij de Franken komen we reeds in de 5e en 6e eeuw de bevoegdheid van de aanklager tegen om zijn aanklacht te bewijzen door middel van getuigen ${ }^{23}$. Deze getuigen verschenen op het ding om te verklaren, dat zij het feit waarover de aanklacht liep zelf hadden waargenomen. Deze oude getuigenverklaringen kwamen dus met die van onze tijd in zoverre overeen, dat zij de eigen walarneming van de getuigen betroffen. $Z$ ij werden echter niet ondervraagd. Zij verklaarden altijd omtrent de gehele inhoud van de klacht en bezwoeren hun verklaring achteraf met een eed ('bevestigingseed'). Bezwoer het vereiste aantal getuigen datgene, waarvan het bewijs bij vonnis door de ramchimburgi was opgelegd, dan was de zaak hiermee beslist. De rechter (graaf) was niet bevoegd zich een oordeel te vormen over de waarde van elke getuigenis. Dat de verklaringen waren bezworen werd genoeg geacht ${ }^{24}$.

Ook deze bewijslevering door middel van getuigen bleef dus formeel van aard. Toch drong langzaam het besef door dat het oordeel op die manier mogelijk op

20 Zic ook E. Schmidt (1965), a.w., p. 43.

21 Zie J.P.H. de Monté Verloren, J.E. Spruit (1982), a.w., p. 30.

22 Zie L.Ph.C. van den Bergh (1842) a.w., p. 25 en J. de Bosch Kemper, Wetboek van Strafvordering. naar deszelfs beginselen ontwikkeld, en in verband gebragt met de algemeene regtsgeleerdheid, Amsterdam 1838, Eerste Deel, Inleiding, p. LXVIII en LXIX.

23 S.J. Fockema Andrcae (1897), a.w., p. 47 en 59.

24 S.J. Fockema Andreac (1897), a.w., p. 60. 
onbetrouwbare grondslagen werd opgetrokken. Men kon getuigen voor zich krijgen, die zich van de feiten gebrekkig rekenschap gaven en te goeder trouw meer verklaarden dan de waarheid. Maar ook verschenen omgekochte getuigen, dronken getuigen of anderszins onbetrouwbare zegslieden. Tot dan toe gold dat hun beëdigde verklaringen beslissend waren. De koningen begrepen, dat deze situatie erg onbevredigend was en in verschillende capitularia ${ }^{3}$ van omstreeks 800 werd het getuigenbewijs dan ook nader geregeld ${ }^{26}$. Zo werden er bijvoorbeeld de volgende eisen gesteld: de getuigen mochten hun verklaring niet tegen betaling afleggen, zij moesten nuchter zijn en de graaf moest hen, alvorens zij op het ding verklaarden en zwoeren, één voor één in verhoor nemen.

De verklaringen van getuigen waren door deze maatregelen misschien wel betrouwbaarder geworden, zij dienden aanvankelijk nog steeds het gehele samenstel van feiten te bestrijken waarop de klacht was gebaseerd. De vormelijkheid van het bewijs bleef daardoor voortbestaan omdat de ramchimburgi uit de verklaringen van een aantal getuigen die ieder slechts van een deel van het te bewijzen feit afwisten, geen conclusie mochten trekken omtrent het geheel. Maar ook aan deze ongewenste situatie werd een einde gemaakt door het invoeren van een recht van onderzoek, de zogenaamde 'inquisitio per testes ${ }^{27}$. Indien tot een 'inquisitio per testes' werd overgegaan, werd een aantal personen, buren, aanzienlijken of geestelijken op straffe van koningsboete op het ding gedaagd. De graaf besliste wie zou worden opgeroepen, maar liet zich voor zijn keuze door de klager inlichten over de vraag, wie van de zalak afwisten. Deze getuigen legden de eed af en werden nu door de graaf op het ding ondervraagd. Daarop werd de beklaagde gehoord en uiteindelijk trokken de rechtsprekenden uit het aangevoerde hun conclusie. Wanneer de graaf ter terechtzitting hen om hun oordeel vroeg dan antwoordden zij daarop met de woorden: "volgens de getuigenis der gehoorde mannen en de uitkomsten van uw onderzoek beslissen wij aldus. ${ }^{\text {nes }}$

\subsection{Het initiatief tot strafienolging}

Wat de vervolging aangaat gold nog steeds de regel: zonder klager geen rechter. Dit adagium heeft zich tot laat in de middeleeuwen gehandhaafd. Toch getuigen

25 Zic P. Traest (1092), a.w., p. 36: "Naast de trouwe bevestiging van de Frankische gewoonterechtstraditic manifesteerde zich evenwel cen drang naar eenheid van wetgeving in het gehele Frankische rijk. Terwijl de Merovingische koningen weinig gebruik hadden gemaakt van hun verordeningsbevoegdheid werden onder Karel de Grote en zijn eerste opvolgers vele wetten gemaakt met een algemene draagwijdte en een toepassing over het gehele Frankische rijk. Deze verordeningen staan bekend als "capitularia", een term die voor het eerst in 779 opduikt."

26 S.J. Fockema Andreae (1897), a.w., p. 61.

27 S.J. Fockema Andreac (1897), a.w., p. 61.

28 S.J. Fockema Andreae (1897), a.w., p. 62 cn 63. 
reeds oude Germaanse berichten al van misdrijven, niet enkel gericht tegen leden van de volksgemeenschap, maar gericht tegen de volksgemeenschap in zijn geheel ${ }^{2}$. En in de oude instructies van de koningen aan de graven komen we herhaaldelijk tegen dat hen wordt opgedragen rovers en landlopers te vervolgen" ${ }^{2}$. Deze ambtshalve vervolgingen werden in de hand gewerkt doordat de graven een geldelijk belang kregen bij de vervolging van misdrijven. Het uitoefenen van de jurisdictie voor de vorst was voor de graaf een lucratieve bezigheid omdat, zoals al bij de oude Germanen gebruikelijk was, het zoengeld en de boeten voor de misdaden tussen de aankla-

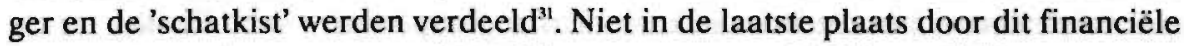
aspect gingen de graven er geleidelijk toe over om ook bij het uitblijven van een klacht ambtshalve oftewel 'ex officio' te vervolgen. Het geldelijk voordeel der strafvordering ging in die gevallen van de bijzondere klagers geheel op de koninklijke ambtenaren over. Dit verklaart hoe ondanks het vervolgingsvereiste van een klacht, al in het Germaanse strafproces de vervolging van ambtswege wel voorkwam.

\subsection{Conclusie}

De bewijsmiddelen in het openbare en mondelinge ${ }^{32}$ Germaanse strafproces zijn in de loop der tijd van aard veranderd. Waren aanvankelijk de toegelaten bewijsmiddelen (de zuiveringseed en andere godsoordelen) van zuiver formele aard, waarbij de dinggenoten, later ramchimburgi, tot veroordeling moesten overgtan wanneer formeel het bewijs was geleverd, langzaam maar zeker speelt de getuigenverklaring een steeds belangrijkere rol in het strafproces. Dit bewijsmiddel dat aanvankelijk ook nog formeel van aard is, ontwikkelt zich langzaam tot een meer materieel bewijsmiddel. Hierdoor verandert ook de rol van de rechter binnen het strafproces. Deze gaat zich meer bezighouden met de waarde van de getuigenverklaringen. De kwaliteit van waarheidsvinding wordt belangrijker.

Wat het initiatief tot vervolging aangaat kan worden vastgesteld dat dit initiatief in het Germaanse strafproces vooralsnog lag bij de klager, maar dat in de loop der tijd de ambtshalve vervolging ook wel voorkwam.

\section{Het Canonieke strafproces}

De invoering van het Christendom als publieke religie ten tijde van de Frankische koningen heeft een blijvende, steeds groter wordende invloed uitgeoefend op het

2) S.J. Fockema Andreac (1897), a.w., p. 70.

30 J. de Bosch Kcmper (18.38), a.w., Eerste Deel, Inleiding, p. LXXI. Zie onk P. Traest (19)2), a.w., p. 37.

31 J.de Bosch Kemper (18.38), a.w., Eerste Deel, Inleiding, p. LXXIII en LXXIV.

32 P. Traest (1\%92), a.w., p. 38. 
inheemse recht ${ }^{33}$. Tussen de Karolingen ${ }^{34}$ en de Kerk werd van weerszijden voordurend onderhandeld om de macht van de Kerk in rechtszaken af te bakenen. De Kerk eiste de rechtspraak over de geestelijke stand en over alle zaken voor zich op, die in dadelijk of meer verwijderd verband stonden met de Kerk. Haar jurisdictie was derhalve gebaseerd op twee uitgangspunten. Ratione personae (uit hoofd van de persoon) vielen onder de jurisdictie van de kerk allereerst haar eigen dienaren. $\mathrm{Al}$ diegenen, die tot de ordo clericorum behoren, van de hoogste prelaat tot de minste monnik, kenden een volledige immuniteit voor het wereldlijke proces. De competentie ratione personae omvatte later ook een aantal groepen personen die niet tot de geestelijke stand behoorden, zoals weduwen, wezen en onder voogdij of curatele gestelden. Bij de zaken die ratione materiae (uit hoofde van het onderwerp) onder de jurisdictie van de kerk vielen, moet gedacht worden aan het huwelijk en het testament ${ }^{35}$.

De Karolingische vorsten (met name Karel de Grote 768-814) waren de Kerk zeer welgezind omdat de Kerk een bindende factor vormde binnen het (uitgestrekte) rijk. Dat verklaart waarom de meest gezaghebbende wetten van de Kerk die op de concilies werden uitgevaardigd, in verschillende capitularia zijn overgenomen. Zo wordt in een capitulare uit 813 aan de graven en rechters bevolen de bisschop te gehoorzamen en elkaar wederkerig te steunen in de uitoefening van de rechtspraak*

\subsection{Het initiatief tot vervolging en bewijsvoering}

Het Canonieke recht ging uit van de opvatting dat elke misdaad een zonde was, die behoorde te worden bestreden. De Kerk beschouwde het als haar enige en tevens hoogste doel om door het opleggen van een bepaalde straf (boetedoening) de schuldige met God te verzoenen. $\mathrm{Zij}$ beschouwde de straf voor de zondaar eerder als een weldaad dan als een leedtoevoeging. Hieruit laat zich verklaren dat de Kerk er geen vrede mee kon hebben dat de vervolging van het misdrijf aan de benadeelde werd overgelaten. Niet deze moest de schuldige ter verantwoording roepen, maar de Kerk, die ook zonder aanklager de schuldige moest kunnen opsporen en berechten ${ }^{37}$. Dit is een belangrijke reden waarom de Kerk relatief vroeg op grote schaal overgaat tot het ambtshalve vervolgen van misdadigers.

33 Zie J.P.H. de Monté Vcrloren, J.E. Spruit (1982), a.w., p. 34 en 35. Zic ook M. van de Vrugt (1982), a.w., p. 7; P. Traest (1992), a.w., p. 37.

34 De Karolingen waren een Frankisch vorstengeslacht dat zijn naam ontleende aan Karel Martel.

35 Zie M. van de Vrugt (1982), a.w., p. 8 en 9.

36 J.H. Drenth (1939), a.w., p. 57 en 58.

37 J.H. Drenth (1939), a.w., p. 64. Zie ook D. Simons (1925), a.w., p. 5 cn K. Geppert, Der Grundsatz der Unmittelbarkeit im deutschen Strafverfahren, Berlin 1979, p. 12. 
Ondanks de heersende opvatting over zonde en hoetedoening was de accusatio aanvankelijk de voornaamste procesvorm binnen het Canonieke strafprocesrecht. Bij deze procesvorm was wel degelijk de aanklacht van een aanklager vereist. De aanklager was verplicht zijn beschuldiging schriftelijk en ondertekend in te dienen. Door deze inscriptio verbond de aanklager zich zijn bewering waar te maken, nam hij de bewijslast op zich en riskeerde hij de op het misdrijf gestelde straf, voor het geval hij in zijn bewijslevering niet mocht slagen. Dit vereiste, waardoor te lichtvairdige klachten werden geweerd, was afgeleid uit het Romeinse recht ${ }^{38}$. Het proces werd geheel mondeling en openbaar gevoerd. Aanklager en beschuldigde moesten beiden tegenwoordig zijn. Partijen moesten zelf hun verdediging voeren en mochten zich niet van hulp van een derde voorzien.

\subsubsection{De denuntiatio}

Allengs kwam een andere procesvorm op, de denuntiatio, die ook al in het laatRomeinse recht niet onbekend was geweest ${ }^{*}$. Bij de denuntiatio werd de formaliteit van de inscriptio afgeschaft en beperkte de werkzaamheid van de denuntians zich tot aangifte van het misdrijf aan de rechter die dan verder de zaak vervolgde buiten hem om. De straf waarmee een valse aanklacht bij de accusatio werd bedreigd viel weg, maar de denuntians bleef gehouden door aanwijzing van getuigen volledig bewijsmateriaal te leveren. De rechter die bij de accusatio een vrijwel lijdelijke rol had vervuld, kreeg bij de denuntiatio een groter aandeel in de procesvoering.

\subsubsection{Notoria en infamatio}

In het Canonieke procesrecht waren er van aanvang af twee gevallen bekend, waarin de rechter zonder dat een aanklacht werd vereist, 'ex officio' kon optreden en de misdadiger tot boete of straf kon veroordelen ${ }^{40}$. Dit deed zich voor bij de 'delicta manifesta' (notoria), dat wil zeggen wanneer er sprake was van een overduidelijke misdaad ofwel zonde, waarbij gedacht moet worden aan overspel, hoererij, afgoderij, moord, ketterij, dronkenschap en dergelijke. De vervolging 'ex officio' was ook toegestaan in geval iemand tengevolge van een geloofwaardig kwaad gerucht (mala fama, infamia, infamatio), de verdenking op zich laadde een misdrijf te hebben gepleegd, of wanneer een aanklager er niet in geslaagd was volledig bewijs te leveren. Wanneer de infamatus in dergelijke gevallen ontkende, was deze verplicht door het afleggen

Zic J.H. Drenth (1939), a.w., p. 72 en K. (icppert (1979), a.w., p. 12 
van een eed (de purgatio) zich van het kwaad gerucht te zuiveren. De purgatio geschiedde door eedaflegging met behulp van eedhelpers. Het doel dat de Kerk met deze reiniging nastreefde, moet gezocht worden in het streven te voorkomen dat door min of meer onbehoorlijk gedrag van de geestelijkheid, de gelovige gemeente werd geërgerd. Niet het door de beschuldigde begane misdrijf maar enkel het kwaad gerucht was voldoende voor het opleggen van een eedreiniging. De achter het gerucht liggende 'waarheid' te achterhalen werd met de purgatio niet beoogd ${ }^{41}$.

\subsubsection{De inquisitio}

$\mathrm{Na}$ het jaar 1000 verloor de accusatio in de praktijk veel van haar waarde, doordat was bepaald dat een geestelijke slechts door zijn gelijke, dat wil zeggen een andere geestelijke, kon worden beschuldigd. Deze onderlinge beschuldigingen kwamen steeds minder voor, omdat men zich niet graag blootstelde aan het gevaar dat de inscriptio met zich bracht, namelijk dat men de straf riskeerde die op het misdrijf was gesteld indien men niet in de bewijslevering slaagde. Ook de denuntiatio raakte in onbruik; uit collegialiteit ging men er steeds minder toe over zich als klager in een proces te mengen. Naar aanleiding van een geloofwaardig kwaad gerucht kon bovendien veelal niet met succes een vervolging worden ingesteld, aangezien door middel van de reinigingseed gemakkelijk aan de strafdreiging kon worden ontkomen. Een scherper toezicht op en een strengere bestraffing van de door de geestelijkheid begane vergrijpen waren meer nodig dan ooit. De onrust binnen de geestelijke stand was groot en dit werd de Kerk herhaaldelijk voor de voeten geworpen ${ }^{4 z}$.

In dit verval vonden veel hervormingen van het Canonieke strafproces hun oorsprong. De eisen die aan het instellen van een accusatio werden gesteld, werden versuepeld. Maar de belangrijkste hervorming bestond hierin dat naar aanleiding van een kwaad gerucht (infamia) een nieuwe procesvorm werd ingesteld, namelijk de inquisitio. Aan het misbruik dat men maakte van de reinigingseed, om zich van een bestaande infamia te zuiveren, werd voorgoed een einde gemaakt door het voorschrift dat, in geval van een infamia, eerst een onderzoek (inquisitio) naar de waarheid van het kwade gerucht diende te worden ingesteld ${ }^{43}$. In de loop der tijd kreeg de inquisitio onder de strafprocesvormen van hel Canonieke recht steeds meer vaste voet aan de grond en dit leidde ertoe dat deze nieuwe procesregels door Innocentius III op het vierde Lateraans Concilie (1215) in een Decreet werden vastgelegd ${ }^{\star}$. Vanaf dit moment onderscheidt het kerkelijke proces zich duidelijk van het

41 J.H. Drenth (1939), a.w., p. $72 \mathrm{t} / \mathrm{m} 75$.

42 J.H. Drenth (1939), a.w., p. $75 \mathrm{t} / \mathrm{m} 77$.

43 J.H. Drenth (1939), a.w., p. 78. Zic ook K. Geppert (1979), a.w., p. 12.

44 J.H. Drenth (1939), a.w., p. 83 en K. Geppert (1979), a.w., p. 12. Zie ook P. Traest (1992), a.w., p. 46: "Zoals het duel, werden ook de proeven door de Kerk eerst gechristianiseerd en enkele eeuwen nadien verboden. Het vierde Concilie van Lateranen verbood in 1215 op de meest absolute 
wereldijke strafproces, zodat dan met recht van een eigen Canoniek strafproces kan worden gesproken ${ }^{45}$, dat vooral gekenmerkt werd door een streven naar betrouwbare waarheidsvinding.

\subsection{Conclusie}

Hoewel de ambtshalve vervolging van aanvang af paste in de opvatting van de kerk over misdaad en zonde heeft de inquisitio niet terstond de accusatio zonder slag of stoot verdrongen. De laatstgenoemde procesvorm genoot in het Canonieke strafproces nog lang de voorkeur. Toen echter eenmaal in het kerkelijke procesrecht het principe van een vervolging van ambtswege was ingevoerd, werd door de praktijk de toepassing van dit principe snel en sterk uitgebreid. Was tot dan toe het ingrijpen van de rechter steeds afhankelijk gesteld van een hem gedane aanklacht, vanaf het midden van de 13 e eeuw leidde een uitgebreide interpretatie van de Pauselijke Decratalen tot de opvatting, dat de rechter zelf, naar eigen goeddunken, het initiatief kon nemen om een onderzoek in te stellen naar het al dan niet bestaan van een kwaad gerucht, zonder genoodzaakt te zijn eerst het indienen van een aanklacht af te wachten. De lijdelijke rechter maakte plaats voor een actief aan het proces deelnemende rechter en allengs ging men ervan uit dat de rechter geheel voor de vervolging van en het onderzoek naar misdaden had zorg te dragen ${ }^{a b}$.

\section{De verdere ontwikkeling van het strafproces in de wereldlijke gerechten vanaf de Germaanse periode tot aan 1570}

Eerder werd aangegeven dat ook in het Germaanse recht de vervolging van ambtswege wel voorkwam. Afgezien van het feit dat deze vervolging 'ex officio' werd gestimuleerd door het geldelijke belang dat de graven hadden bij de vervolging, was men toch ook gaan inzien dat men voor de handhaving van de orde en rust niet kon volstaan met de strafvervolging op basis van een klacht. De Frankische koningen beseften blijkbaar dat het algemeen belang de bestraffing der misdrijven vereistc, zodat men dit niet enkel van het goedvinden van de beledigde partij kon laten afhangen.

wijze de medewerking van de clerus aan de organisatic van godseordelen. Deze werden immers beschouwd als bet uitdagen en tarten van God, wat uit den boze was."

45 K. Geppert (1979), a.w., p. 12. Zic ook P. Tracst (1992), p. 39.

46 J.H. Drenth (1939), a.w., p. 85. 
In het inheemse recht ontstonden rond de 9 e eeuw als gevolg van de noodzaak tot ambtshalve vervolging zogenaamde vroegingsgerechten of gemene waarheden. De graaf nam hierbij de rol over van de klager en haseerde zijn klacht op gemene waarheden. Deze gemene waarheden ${ }^{37}$ waren eigenlijk niet meer dan getuigenverklaringen van horen zeggen. Hetzij op vaste tijden, hetzij wanneer een kwaad gerucht daartoe aanleiding gaf, beëdigde de graaf daartoe een aantal geloofwaardige mannen, die dienden te verklaren over alle misdrijven die hen ter kennis waren gekomen ${ }^{48}$. Hun verklaringen waren door de eedaflegging bewijskrachtig, zonder dat een onderzoek werd gedaan naar de redenen van wetenschap. Het houden van gemene waarheden vond oorspronkelijk plaats in het openbaar. De onderdanen van de graaf waren echter niet blij met hun vroegingsplicht en zij toonden zich niet altijd even bereid om als verklikkers van hun dorpsgenoten op te treden". Later in de steden vond dit getuigenverhoor hier en daar ${ }^{50}$ dan ook plaats in het geheim. Vandaar dat men dan wel sprak van de 'stille waarheid"s:

Het is niet precies duidelijk waaruit het gebruik van de folter is ontstaan, maar het is goed mogelijk dat de weerstand van de vroegingsplichtigen om als getuige op te treden heeft bijgedragen tot het in gebruik raken van dit middel. De Vries is van mening dat men het gebruik van de folter kan beschouwen als een vereenvoudigde walarheid: de beklaagde 'kent over hemselven' en fungeert als getuige ${ }^{52}$. Bovendien paste het onstaan van de folter bij het groeiende streven de materiële waarheid aan het licht te brengen, waartoe bij gebrek aan ander bewijs - denk aan de teloorgang van de godsoordelen - de beklaagde steeds meer voorwerp van onderzoek werd ${ }^{33}$. In ieder geval was reeds voor de vestiging van het Bourgondische gezag (1384-1482) de pijnbank in verschillende Noord-Nederlandse steden in zwang. Begonnen als incident, is de foltering tot vooronderzoek geworden, dat in het geheim (in de kerker) gehouden werd. De beklaagde moest zijn bekentenis ongebonden buiten de kerker herhalen ten overstaan van de schepenen ${ }^{54}$. Droeg de toepassing van de

47 Zie ook L.Ph.C. van den Bergh (1842), a.w., p. $49 \mathrm{t} / \mathrm{m} 57$.

48 Zie S.J. Fockema Andreae (1897), a.w., p. 80 en J.H. Drenth (1939), a.w., p. 187.

49 S.J. Fockema Andreae (1897), a.w., p. 82.

50 Met name in de Hollandse en Zecuwse steden; daarbuiten treft men in de noordelijke Nederlanden 'de waarheid' slechts sporadisch aan, aldus K. de Vries, Bijdrage tot de kennis van het strafprocesrecht in de Nederlandse steden benoorden Maas en Schelde; voor de vestiging van het Bourgondisch gezag, Groningen 1955, p. 235.

51 J.H. Drenth (1939), a.w., p. 191. Zic ook K. de Vries (1955), a.w., p. 234.

52 K. de Vries (1955), a.w., p. 189. Zie ook J.L.M. Bock en J.F. Nijboer, De bekentenis als de koningin van het bewijs, D\&D 1994, p. 41 en 42.

53 Zie: ook E. Schmidt (1965), a.w., p. 91: "Die Anwendung der Folter ist das sicherste Zeichen dafür da $\mathrm{B}$ die Obrigkeit von sich aus mit Hilfe der Erklärungen und Aussagen des Beschuldigten den tatsächlichen Sachverhalt erforschen will." en P. Traest (1992) a.w., p. 61 t/m 63.

54 Zie K. de Vries (1955), a.w., p. 188, dic zich baseert op het Rechtsbock van Den Briel. 
tortuur aanvankelijk nog het karakter van een noodoplossing, in de loop der tijd werd de bekentenis van de verdachte het belangrijkste bewijsmiddel in het wereldlijke strafproces en werd het gebruik van de folter algemeen aanvaard.

\subsection{Geen eenheid van recht}

Hoewel de ontwikkeling van het strafproces in de wereldlijke gerechten in onze contreien in grote lijnen kan worden beschreven als hiervoor is gebeurd, moet men goed in het oog houden dat het procesrecht hier te lande in de middeleeuwen toch een versplinterde, onsystematische en willekeurige indruk maakt. Dit werd vooral veroorzaakt door het feit dat het gebied, als gevolg van het leenstelsel, het ontstaan van landsheerlijkheden, het onstaan van de steden en de verzelfstandiging van de kerkelijke macht, was opgedeeld in talloze rechtskringen, die soms personeel (bijvoorbeeld tussen leenman en leenheer), soms territoriaal (bijvoorbeeld binnen de rechtskring van de stad) en door elkaar werkten ${ }^{55}$. Ook tussen het strafprocesrecht van de verschillende steden konden grote verschillen bestaan. Dit was een gevolg van het feit dat de vrijheid van een stad om zijn eigen jurisdictie uit te oefenen, afhing van wat daarover was bepaald in de stadsbrief waarbij stadsrecht was verleend.

Het stadsrecht werd verleend door het hoogste gezag in het gebied, derhalve soms door de koning, maar meestal door de graven, die in de loop der tijd waren uitgegroeid tot zelfstandige landsheren. Toen de macht van de graven na het verval van de macht van Karolingische koningen was gegroeid, gingen zij ertoe over 'baljuwen' of 'schouten' aan te stellen om voor hen de rechtspraak waar te nemen ${ }^{\text {:\$. }}$. Net zoals de graven voor die tijd waren deze baljuwen zeer vourdelige ambten, onder andere door de verbeurdverklaringen van de goederen van de misdadigers en de bevoegdheid tot dading. Bij stadshrief werden deze ambten door de graven afgestaan tegen het inwilligen van beden; zij werden aan zekere personen verkocht of verpand. Zo ontstonden er (in de 14e eeuw en later) in de Nederlanden verschillende, van elkaar onafhankelijke rechtbanken, die elk een eigen organisatie bezaten, al naar gelang de privileges en giftbrieven. Men vond in de steden bijna overal schepenrechtbanken met een baljuw of een schout, terwijl de rechtspleging door de stedelijke keuren werd bepaald ${ }^{57}$.

Zie J.P.H. de Monté Verloren, J.E. Spruit (1982), a.w., p. 187 t/m 190.

Zie ook J. de Bosch Kemper (1838), a.w., Eerste Deel, Inleiding, p. LXXIV en LXXV.

57 J. de Bosch Kemper (1838), a.w., Eerste Deel, Inleiding, p. LXXV I/m LXXVII; P. Traest (1992), a.w., p. 39. 


\section{De Constitutio Criminalis Carolina en de verdere ontwikkeling van het Duitse strafproces}

Aan het begin van de $16 \mathrm{e}$ eeuw kwamen de Nederlandse gewesten onder het gezag van een en dezelfde landsheer, Karel V (1506-1555). Deze Habsburgse vorst heeft in navolging van zijn Bourgondische voorgangers, gevoed door een streven naar centralisatie van zijn macht, en in het voetspoor van hetgeen de Franse koningen sedert medio 15e eeuw in Frankrijk hadden bewerkstelligd, getracht aan de rechtsongelijkheid op het gebied van het strafprocesrecht een einde te maken ${ }^{5 s}$. In 1532 kwam onder zijn leiding de Constitutio Criminalis Carolina tot stand, die hoewel afgekondigd voor het gehele Heilig Roomse Rijk, waartoe toen ook Nederland behoorde, vooral in de Duitse gebieden gelding heeft gehad. De redenen waarom de pogingen van Karel V om ook bij ons zijn 'peinliche Gerichtsordnung' in te voeren, mislukten, moeten waarschijnlijk gezocht worden in de weerstand van de steden en in de omstandigheid dat de Carolina, die op Duitse gewoonte herustte, minder geschikt was voor onze gewesten".

\section{I De Constitutio Criminalis Carolina (15.32)}

De Carolina trachtte niet zozeer nieuw recht te scheppen". De bedoeling was vooral een overzicht te geven van de in gebruik zijnde keizerlijke rechten en goede gewoonten ten dienste van de ongeleerde rechters en schepenen". De lagere gerechten waren immers net zoals bij ons in de regel niet met juristen bezet. Op het eerste gezicht leek het er dan ook op dat wat de organisatie der gerechten betreft, alles bij het oude bleef. Zo werden de schepenen, de ongeleerde volksoordelaars gewoon gehandhaafd. Maar de splitsing tussen procesleiding en beslissers werd wel afgeschaft.

58 Zie J.P.H. de Monté Verloren, J.E. Spruit (1982), a.w., p. 200.

59 J. de Bosch Kemper (1838), a.w., Eerste Deel, Inleiding, p. LXXXII en LXXXIII. Er zijn overigens enkele thans Nederlandse gebiedjes aan te wijzen waar de Carolina als formele rechtsbron wel cen rol heeft gespeeld. Zie G.F.M. Bossers en J.F. Nijboer, De actualiteit van de Carolina, D\&D 1989 , p. 7.

60 Voor de doorwerking van de Carolina in de gebicdsdelen van het Heilig Rooms Rijk is rechtspolitiek van belang geweest dat zij een zgn. salvatorische clausule bevatte, waarin bestaand locaal recht werd gerespecteerd. Dit vooral procesrechtelijke wetboek vormde slechts een subsidiaire rechtsbron. Zie G.F.M. Bossers en J.F. Nijboer (1989), a.w., p. 8 en 10.

61 J.H. Drenth (1939), a.w., p. 127. Zie ook E. Schmidt (1965), a.w., p. 125: "Alle ihre rezipierten Neuerungen aber vereinigen sich in der Tendenz, Form und Gestalt, mit einem Worte: Ordnung in den Inquisitionsproze $B$ hineinzutragen. Mit Hilfe von Normen, dic den Einsatz obrigkeitlicher Gewalt nach rationellen Gesichtspunkten regeln, das richterliche Ermessen in vernünftige Bahnen lenken und der Willkür und Unerfahrenheit steuern sollen, werden prozessualen Formen geschaffen, die der Wahrheit und Gerechtigkeit dienen sollen." 
De procesleidende rechter (in oude zin) ${ }^{62}$ werd aan de beslissers toegevoegd. Dit leidde op den duur tot een steeds sterker overwicht van de rechter oude stijl op de ongeleerde mede-oordelaars, die spoedig naar het tweede plan werden teruggedrongen. In afwijking van het recht dat tot dan toe had gegolden, nam de rechter voortaan een werkzaam aandeel in het bepalen van het vonnis ${ }^{\mathrm{al}}$.

\subsubsection{Het bewijsrecht van de Carolina}

Wat het bewijsrecht aangaat, kan worden vastgesteld dat ten tijde van de Carolina de oude bewijsmiddelen uit het Germaanse strafproces, zoals de eed en andere godsoordelen, in onbruik waren geraakt. Mede beïnvloed door het Canonieke procesrecht werd het streven naar materiële waarheidsvinding in het strafproces werd steeds belangrijker. Vandaar dat we in de Carolina de eerste aanzetten voor een gedifferentieerde bewijsleer aantreffen.

De Carolina onderscheidde zeer strikt tussen de vragen, wanneer en onder welke voorwaarden veroordeeld en wanneer gefolterd mocht worden. Een veroordeling kon niet op aanwijzingen worden gebaseerd; zij was slechts mogelijk bij een geloofwaardige bekentenis of bij overtuiging door minstens twee getuigen. Daarbij dienden die getuigen te verklaren over hetgeen zij zelf gehoord en gezien hadden. De getuigenis van horen-zeggen kon nimmer tot een veroordeling leiden. Wanneer een vrijwillige bekentenis van de beschuldigde niet te verkrijgen was en het bewijs door minstens twee geloofwaardige getuigen niet kon worden geleverd, kon tot de 'pijnlijke vraag' (foltering) worden overgegaan. Dit was echter alleen mogelijk wanneer er voldoende verdenking bestond. In dit verband ontwikkelde de Carolina een gedetailleerde aanwijzingenleer, die aan het gebruik van de folter grenzen poogde te stellen. Zo kon de getuigenis van horen-zeggen het gebruik van de pijnbank niet rechtvaardigen ${ }^{t *}$.

62 Zie $\S 2$ en 3 van dit hoofdstuk.

63 J.H. Drenth (1939), a.w. p. $128 \mathrm{I} / \mathrm{m}$ 130, Zie ook K. Geppert (1979), a.w., p. 15. Door deze maatregel veranderde de positie van de rechter (in moderne zin) ook in staatsrechtelijk opzicht; hij werd ambtenaar, door de overheid aangesteld. Deze vereniging van de uitvoerende macht met de rechtsprekende macht in de figuur van rechter, die in ons land nooit in dezelfde mate heeft plaatsgevonden, doordat zich hier een openbaar ministeric ontwikkelde, is er volgens De Bosch Kemper een van de belangrijke oorzaken van geweest dat in Duitsland het inquisitoire proces zulke excessieve vormen heeft kunnen aannemen. Zie J. de Bosch Kemper (1838), a.w., Eerste Deel, Inleiding, p. LV.

64 Zie over het bewijsrecht van de Carolina: J.H. Drenth (1939), a.w., p. 131 1/m 135; E. Schmidt (1965), a.w., p. 127 I/m 130 en K. Geppert (1979), a.w., p. 18 en 19. 


\subsubsection{Het schriftelijke karakter van het proces}

De Carolina bepaalde dat de rechters in alle twijfelgevallen over het toe te passen recht, de raad van een extern rechtsgeleerd college ${ }^{\text {ns }}$ dienden in te winnen. Dit voorschrift was voortgekomen uit het inzicht dat de ongeleerde rechters in veel gevallen de kennis en ervaring misten, om het in de Carolina neergelegde recht goed toe te passen ${ }^{\star}$. Om aan dit voorschrift te voldoen dienden alle relevante onderzoeksresultaten in schriftelijke stukken vastgelegd te worden, zodat ze aan dit college konden worden toegezonden ${ }^{67}$. Een waarschijnlijk ongewild gevolg van deze wetgeving was, dat in die gevallen de eigenlijke beslissing niet bij de rechters (in moderne zin) maar bij dit rechtsgeleerd college kwam te liggen. Dit college oordeelde op de schriftelijke stukken, zonder verder de beschuldigde en andere bewijsmiddelen zelf te aanschouwen. Het proces van de Carolina verkreeg hierdoor een schriftelijk karakter ${ }^{\text {tht }}$.

Maar ook in de weinige gevallen dat het gerecht zelf zijn oordeel kon vellen, werd de procedure na verloop van tijd steeds meer gekenmerkt door een gebrek aan openbaarheid en door een grote hoeveelheid schriftelijke stukken. In dergelijke gevallen werd de zaak in termijnen behandeld. Dat leidde ertoe dat spoedig enkel voor de belangrijkste fasen van het proces een volledig gerecht samenkwam. De meeste oordelaars woonden het proces slechts gedeeltelijk bij en kwamen alleen door kennis te nemen van de stukken op de hoogte van de verschillende bewijsmiddelen. Daar kwam nog bij dat de Carolina toeliet dat het verhoor van getuigen buiten het proces plaatsvond. Dit werd overgelaten aan commissarissen die hiertoe van overheidswege werden benoemd.

Donr deze ontwikkelingen werd een belangrijk deel van de bewijsverzameling aan de openbaarheid onttrokken en de procesvoering van vergaand schriftelijke alard ${ }^{\text {tw }}$. De openbare en mondelinge terechtzitting waarmee het proces eindigde deed hieraan niets af. Op deze openbare terechtzitting, waartoe het publiek middels klokkengeschel werd opge roepen, vond weliswaar een mondelinge behandeling van de zaak tussen partijen plaats, maar deze behandeling kon geen basis meer vormen

65 K. Geppert (1979) schrijft hierover dat het moest gaan om een "Kollegium der Oberhöfe (Behörden des Landesherrn), der Rechtsfacultäten oder der mit ausgebildeten Juristen besetzten 'Schöppenstühle', a.w., p 15.

66 E. Schmidt (1965), a.w., p. 134 en 135.

67 Zie E. Schmidt (1965), a.w., p. 135: "Damit hat die CCC den Grund gelegt für einen bis ins 19. Jahrhundert geübten Brauch, nämlich für das Institut der sogenannten 'Aktenversendung'. Stellı der Richter fest, daß eine Sache 'vber sein verstendtnus' geht, so sendet er dic Akten mit der Bitte um Rechtsbelehrung an ein solches Gremium Rechtsverständiger ein. Ja, es wurde üblich, daß alle wichtigen Fragen, namentlich die, ob zu foltern sei, sowic, wie zu urteilen sei, den Rechtsverständigen vorgelegt wurden."

68 Zic S. Maas, Der Grundsatz der Unmittelbarkcit in der Reichsstrafprozeßordnung, Breslau 1907, p. 19. J.H. Drenth (1939), a.w., p. 130 en K. Geppert (1979), a.w., p. 15 en 16.

69 Zie S. Maas (1907), a.w., p. 20; H.E. Löhr, Der Grundsaiz der Unmittelbarkeit im deutschen StrafprozeBrecht, Berlijn 1972, p. 27 en K. Geppert (1979), a.w., p. 17. 
voor de beslissing. Reeds voorafgaand aan deze zitting moest het gerecht zijn oordeel hebben bepaald. Vroeg de rechter op oud-Duitse wijze de schepenen om hun oordeel, dan verwezen deze in hun antwoord naar de beslissing die reeds in de stukken was vastgelegd. Dit oordeel werd daarop openbaar verkondigd. Deze openbare zitting, die gezien kan worden als een gebaar naar oud-Duitse traditie, vormde daarmee niets meer dan een ceremonie, waarmee het proces werd beëindigd ${ }^{\text {}}$.

\subsubsection{Het initiatief tot vervolging}

Wat het initiatief tot vervolging aangaat, de Carolina kende naast de aanklacht, die enerzijds door de benadeelde, anderzijds door een ambtelijke aanklager kon worden ingediend, ook de vervolging van ambtswege, zonder dat daarvoor een aanklacht was vereist. Deze laatste mogelijkheid, die volgens de Carolina als de uitzondering gold, werd in de praktijk regel. Maar ook in de gevallen dat het proces met een aanklacht begon, kenmerkte het verloop zich door een eenzijdig rechterlijk onderzoek naar de materiële waarheid ${ }^{5}$. Dat bracht met zich dat er een soort vooronderzoek ontstond, waarbij de bewijsverzameling niet ten overstaan van het gerecht plaatsvond $^{72}$. Ook deze ontwikkeling heeft het gebruik van schriftelijke stukken bevorderd.

\subsection{De ontwikkeling van het Duitse strafproces na de Carolina}

In de periode na de Carolina ontstaat op Duits grondgebied het geheime, schriftelijke proces dat ambtshalve in gang wordt gezet en dat uiteindelijk heeft geleid tot de hervormingsbeweging van de $19 \mathrm{e}$ eeuw ${ }^{73}$. De openlijke en mondelinge procesvoering op basis van klacht had het definitief afgelegd ten gunste van de geheime ambtshalve vervolging. Het geheime proces werd opgedeeld in twee strikt gescheiden onderzoeksdelen $^{74}$. In de 'Generalinquisition' ging het heel algemeen over de vraag of een

70 Zie S. Malas (1907), a.w., p. 18; H.E. Löhr (1972), a.w., p. 28; K. Geppent, a.w., p. 17 en W. Schild, Der 'endliche Rechtstag' als das Theater des Rechts, In: Strafrecht, Serafprozess und Rezeption, Frankfurt am Main 1984, p. 119 1/m 144; G.F.M. Bossers en J.F. Nijboer (1989), a.w., p. 16 en 17.

71 Zie E. Schmidı (1965), a.w., p. 126: "Vor allem aber ist zu beachten, daß der Akkusationsproze $B$ der CCC gar nichts anderes als cin reiner Inquisitionsproze $B$ ist, bei dem dic Anklage seitens eines privaten oder eines öftentlichen Klägers nur als eine auch noch mögliche Prozeßcinleitungsform beibehalten worden ist. In der Sache selbst und für die ganze sonstige Struktur des Verfahrens hat diese Prozeßeinleitungsform aber so gut wie gar nichts zu bedeuten."

72 K. Geppert (1979), a.w., p. 17.

73 De werken van Benedict Carpzows (1595-1666) hebben op het begin van deze ontwikkeling een duidelijke invloed gehad, zie S. Maas (1907), a.w., p. 20; E. Schmidt (1965), a.w., p. 197; H.E. Löhr (1972), a.w., p. 28 en K. Gepperl (1979), a.w., p. 20 en 21.

74 Zie E. Schmidt. (1965), a.w., p. 177 en 195 t/m 197 en K. Geppert (1979), a.w., p. 20. 
bepaalde daad was begaan en wie als dader daarvan in aanmerking kon komen. Deze fase was op zich zelf bedoeld ter bescherming van de beklaagde, die weliswaar door de onderzoeksrechter (de inquirent) kon worden verhoord, maar nog niet als inquisitus kon worden gevangengezet en gefolterd. Dit was eerst mogelijk gedurende de tweede fase, de 'Spezialinquisition'. De beklaagde en ook de getuigen werden in deze fase voor de tweede maal verhoord, nu in het kader van de zogenaamde 'artikulierten Verhören'. Op grond van de 'Generalinquisition' had de onderzoeksrechter, die meestal tevens lid was van het later vonnissende gerecht, de gehele processtof in schriftelijk geformuleerde vragen vertaald om in de aansluitende 'Spezialinquisition' de verhoren aan de hand van deze artikelen te kunnen afnemen.

De afsluitende openbare terechtzitting werd afgeschaft. Het vonnissende gerecht veroordeelde enkel op grond van schriftelijke stukken. De direkte waarneming van de bewijsmiddelen ontbrak. Deze werd vervangen door middel van de zogenaamde 'Gebärdenprotokollen'. Daarin pongde de requirent zo precies mogelijk houding, toon, mening, gebaren, uitroepen, gezichtsuitdrukkingen, tegenspraak en andere opvallendheden van getuigen en de beklaagde vast te leggen $n^{75}$.

\subsubsection{Positief wettelijk hewijsstelsel}

Met de opkomende afkeer van de folter moest ook het hele bewijssysteem veranderen. Bood het bewijssysteem van de Carolina de rechter louter richtlijnen bij zijn bewijswaardering, in deze periode ontwikkelde zich een bewijsstelsel, waarbij de rechter gebonden was aan de bewijswaardering zoals die in zijn algemeenheid in de wet was vastgesteld. De hekentenis van de verdachte bleef het belangrijkste bewijsmiddel. De folter was alleen nog toegelaten bij ernstige misdrijven, maar werd daarbij aan minder strenge voorwaarden gebonden.

\subsubsection{Kennis van de feiten uit derde hand}

Rond het begin van de $19 \mathrm{e}$ eeuw werden in de meeste Duitse staatjes alle als bescherming voor de beklaagde bedoelde procesformaliteiten een voor een afgeschaft. Het onderscheid tussen de 'General'- en 'Spezialinquisition' en het daarmee samenhangende dubbelwerk van het tweemaal verhoren werd als overbodig opgeheven ${ }^{70}$. Men gaf de voorkeur aan het eenmalige verhoor. Wel werd de inquirent van het vonnissende gerecht gescheiden, maar zijn macht werd er niet minder door ${ }^{\top}$. Hij bleef de helangrijkste man in het strafproces. Hoewel de folter in deze tijd definitief werd afgeschaft, betekende dit voor de beklaagde in het strafproces niet het begin van

75 S. Maas (1907), a.w., p. 21 en 22; H.E. Löhr (1972), a.w., p. 29 en K. Géppert (1979), a.w., p. 20.

76

E. Schmidt (1965), a.w., p. 205 en 206 en K. Geppert (1979), a.w., p. 21.

77

K. Geppert (1979), a.w., p. 21. 
betere tijden. De bekentenis bleef van doorslaggevend belang voor een veroordeling. Voor de inquirent vormde het verkrijgen van die bekentenis dan ook de hoogste prestatie en een bewijs van zijn onderzoekskunst. De verdachte betekende voor hem niets anders dan het object van zijn onderzoek. De requirent vatte de resultaten van zijn onderzoek in schriftelijke stukken samen en overhandigde deze aan het oordelende college. Dit college besliste dan uitsluitend op grond van deze stukken zonder de beschuldigde of getuigen persoonlijk gezien te hebben.

Om de colleges, die door de veelheid aan processen vaak overbelast waren, te ontlasten, liet men bovendien toe dat enkel één lid van dat college (de referent) alle processtukken las ${ }^{\text {T. }}$. Deze maakte voor de overige leden van het gerecht een samenvatting van de beslissingsrelevante stof en diende daarbij een beslissingsvoorstel in. Het lag voor de hand dat de referent in zijn voorstel hoofdzakelijk die aspecten van de zaak belichtte, die naar zijn oordeel relevant waren. Het gerecht nam op die manier uit derde hand kennis van de feiten.

Het strafproces dat aan het begin $19 \mathrm{e}$ eeuw in de wetgeving van verschillende Duitse staatjes neerslag had gevonden, kan zodoende worden omschreven als geheim en puur schriftelijk.

\subsubsection{Groeiend protest}

Langzaam maar zeker groeide echter ook de weerstand tegen de onstane vormen van proces. Die weerstand werd gestimuleerd door drie deels samenhangende ontwikkelingen" $n^{\text {. }}$.

In de eerste plaats kan gewezen worden op de Franse Revolutie van 1789. Het absolutisme en het daarmee samenhangende geheime en schriftelijke proces waren totaal in strijd met de ideeën van de verlichting, die ook in Duitsland begonnen door te dringen. Met de door het opkomende liberalisme nagestreefde nieuwe staat, waarbij de bescherming van het individu tegen de staatsalmacht en de participatie en medeverantwoordelijkheid van het volk aan deze staat op de voorgrond stonden, was het bestaande procesrecht onverenigbaar.

Maar nog afgezien daarvan ontwikkelde zich een algemene ontevredenheid met de traditionele vormen van het strafproces. Onderwerp van kritiek waren in het bijzonder de onbegrensde macht van de inquirent en de daarmee verbonden onmacht van de geïnquireerde, de vereniging van meer elkaar uitsluitende processuele functies in één persoon, de oordeelsvelling door beroepsrechters die hun oordeel op schriftelijk en door de referent tendentieus samengesteld bewijsmateriaal baseerden, de gebrekkige openbaarheid en niet in de laatste plaats de positief wettelijke bewijstheoriën.

78 Zie S. Maas (1907), a.w., p. 22 en 23 en K. Geppert (1979), a.w., p. 22.

79 K. Gcppert (1979), a.w., p. 67. 
Tenslotte dient ook nog de invloed genoemd te worden die voortvloeide uit het feit, dat de r ranse Code d'Instruction Criminelle van 1808 ook na de periode van de napoleontische overheersing, in de Duitse gebieden links van de Rijn, bleef voortbestaan ${ }^{\infty}$. In vergelijking tot het Duitse vormde dit Franse proces een lichtend voorbeeld van rechtvaardigheid en zorgvuldigheid.

\subsubsection{Het strafproces van de Code d'Instruction Criminelle (1808)}

Het strafproces van de Code d'Instruction Criminelle kan worden gezien als een compromis ('système mixte') tussen het op de ideeën van de verlichting gebaseerde en het door de Engelse procesvorm beïnvloede, liberale post-revolutionaire strafpro${ } \mathrm{ces}^{\mathrm{gl}}$ enerzijds en het inquisitoire proces van het ancien régime, zoals dat tenslotte in de 'Grand Ordonnance sur la procédure criminelle' van Lodewijk XIV was gesanctioneerd, anderzijds. Tot de essentie teruggebracht betekende dit dat het proces bestond uit een geheim, schriftelijk en niet-contradictoir vooronderzoek, zonder bijzondere verdedigingsgaranties voor de beklaagde en een eindonderzoek dat daarentegen in beginsel wel gekenmerkt werd door openbaarheid en een op tegenspraak gebaseerde mondelinge procesbehandeling ${ }^{k 2}$.

\subsection{Het bewijsrecht van de Code d'Instruction Criminelle}

Het bewijsrecht van de Code d'Instruction Criminelle was gebaseerd op twee belangrijke procesbeginselen.

Uitgangspunt was dat de rechter ambtshalve de materiële waarheid diende te achterhalen ('le pouvoir d'initiative et le devoir d'investigation du juge'), hetgeen zich openbaarde in de grote discretionaire macht van de gerechtsvoorzitter.

Het andere belangrijke uitgangspunt van het Franse bewijsrecht vormde de vrije bewijswaardering ('intime conviction'). Dit beginsel, dat beschouwd kan worden als een vrucht van de verlichting richtte zich onmiskenbaar en in eerste instantie tegen de wettelijke bewijstheorieën van het traditionele Franse proces met zijn gebruiken van halve of gebrekkige bewijzen en tegen de oude overdreven aanwijzingenleer. Het richtte zich tegelijkertijd tegen het Engelse systeem van bewijsuitsluitingsregels, dat met het nieuwe idee van de volkssouvereiniteit onverenigbaar werd geacht. Men was van mening dat men de gezworenen gecn bewijsmiddelen diende te onthouden, wegens algemeen vermoede onbetrouwbaarheid zoals in Engeland, omdat men moest vertrouwen op de oordeelskracht van het volk. De betrouwbaarheid van een bewijs-

80 Zic E. Schmidt (1965), a.w.,p. 281; H.E. Löhr (1972), a.w., p. 31 cn K. Geppert (1979), a.w., p. 67. Zie hierover ook G.F.M. Bossers, "Welk eene natie die de jurij gehad heeft, en ze weder afschaft!", Delft 1987, p. 99.

81 Zic over dit post-revolutionaire strafproces: G.F.M. Bossers (1987), p. $10 \mathrm{cn} 11$.

82 K. Geppert (1979), a.w., p. 42 en 43. Zie ook D. Simons (1925), a.w., p. 15; G.F.M. Bossers (1987), p. 19 . 
middel in het concrete geval diende aan hun oordeel overgelaten te worden. Bovendien zouden dergelijke bewijsuitsluitingsregels in strijd zijn met de plicht voor de rechter en gezworenen om de materiële waarheid te achterhalen. Ieder bewijsmiddel dat enig licht op de toedracht van het gebeurde kan werpen, diende gebruikt te kunnen worden. Ourspronkelijk slechts als instructie voor de gezworenen bedoeld, werd dit beginsel van de 'intime conviction' al snel van toepassing op alle processen en dus ook op colleges bestaande uit beroepsrechters en alleensprekende rechters ${ }^{* 3}$.

\subsection{Het beginsel der 'oralité'}

Het bewijsrecht van de Code d'Instruction Criminelle kende een gesloten catalogus van bewijsmiddelen ${ }^{84}$.

Het verdachtenverhoor (lees: de jacht op de bekentenis van de beklaagde) stond ook in de dagelijkse praktijk van het Franse strafproces evenals vroeger in het middelpunt van de bewijsvoering. Wel kende het Code d'Instruction Criminelle voor de beklaagde geen spreekplicht. Maar was een bekentenis eenmaal verkregen, dan werd onafhankelijk van het feit of het hier een gerechtelijke dan wel buitengerechtelijke bekentenis betrof - de bewijswaardering daarvan overgelaten aan de rechter of de gezworenen ${ }^{\mathrm{ss}}$.

Ten aanzien van het getuigenverhoor valt de gestrengheid op waarmee volgens goede orde gedagvaarde getuigen verplicht waren om voor het gerecht te verschijnen en tot (waarheidsgetrouwe) uitspraak verplicht waren. Deze voorschriften vlociden voort uit de eis van het 'débat orale', dat als dé fundamentele regel van het nieuwe Franse strafproces werd gezien". Dit idee van het débat orale was afkomstig uit het Engelse partijenproces en van de daar verwezenlijkte 'equality of arms' nagebootst. Zoals de naam tot uitdrukking wil brengen, moest tussen partijen een mondelinge strijd gevoerd worden. Hieruit vloeide voort dat getuigen (en ook deskundigen) op het eindonderzoek zelf aanwezig moesten zijn en mondeling hun verklaringen dienden af te leggen. Alleen dan zou het de beschuldigde kunnen lukken, de getuigen op tegenspraak, onduidelijkheden en onvolledigheden opmerkzaam te maken.

Hierbij moet echter wel worden opgemerkt dat het bewijsrecht van de Code d'Instruction Criminelle, als logische consequentie van bovengenoemde uitgangspunten, geen bepalingen kende die het gebruik van een getuigenverklaring van de inhoud van die verklaring afhankelijk maakten. Zo bestonden er bijvoorbeeld geen voorschriften betreffende een verklaring van horen zeggen. Het Franse bewijsstelsel ging

83 K. Geppert (1979), a.w., p. 58 en 59.

84 Naast het verhoor van de beschuldigde, het getuigenverhoor en het stukkenbewijs kende de bewijscatalogus van de CIC nog het deskundigenbewijs en de gerechtelijke schouw, welke laatste twee, hier niet aan de orde zullen komen.

85 K. Geppert (1979), a.w., p. 60.

86 K. Geppert (1979), a.w., p. 62. 
ervan uit dat vragen ten aanzien van de betrouwbaarheid van een bewijsmiddel op het niveau van de bewijswaardering dienden te worden beantwoord ${ }^{87}$.

Voor wat het stukkenbewijs aangaat, werd voorgeschreven dat alle schriftelijke stukken ter terechtzitting in aanwezigheid van de beklaagde moesten worden voorgelezen. Dit voorschrift was eveneens een logische consequentie van het aan het Franse eindonderzoek neergelegde beginsel der oralité.

\subsection{De Duitse henormingsbeweging van de 19 e eeuw}

In eerste instantie was het bijna uitsluitend de wetenschap die de strijd aanbond ten behoeve van de hervorming van het Duitse strafproces. Als schrijvers die hier een pioniersrol hebben gespeeld, kunnen worden genoemd Anselm Ritter von Feuerbach (1775-1833) en Carl Joseph Anton Mittermaier (1787-1867). Gezien het geheime en schriftelijke karakter van het Duitse strafproces uit die tijd, mag het geen verwondering wekken dat men in de openbaarheid en de mondelinge behandeling naar het voorbeeld van het Franse proces de oplossing dacht te vinden voor de misstanden die het Duitse proces met zich bracht ${ }^{\text {ss }}$.

In zijn bekend geworden boek 'Betrachtungen über die Oeffentlichkeit und Mündlichkeit der Rechtspflege' maakt Von Feuerbach een onderscheid tussen interne ('partheiliche') en externe openbaarheid ('volkstümliche Oeffentlichkeit'). Feuerbach pleit voor een strenge doorvoering van de interne openbaarheid. Uit dit beginsel van de interne openbaarheid vloeit volgens hem voort dat getuigen ter zitting hun verklaringen moeten afleggen omdat: "Wie sie (de schriftelijke verklaringen uit het vooronderzoek) geworden, was hinter ihnen liegt, was ihnen vorausging, was nebenbei geschah, als sie angefertigt wurden: von allem dem erscheint an ihnen mehr nicht, als sie selbst davon zu melden für gut fanden." "(.) Protokolle legen wenigstens wider sich selbst kein Zeugnis ab. Klagt aber der Angeschuldigte das Protokoll und den Richter an, so können die stummen Wände für ihn kein Zeugniß. geben. ${ }^{100}$

Mittermaier daarentegen concentreert zich in zijn boek 'Die Mündlichkeit, das Anklageprinzip, die Oeffentlichkeit und das Geschworenengericht' meer op de eis van de mondelinge procesvoering: "(..) daß schon in der beschränkten Form die wohlthätigen Wirkung der Mündlichkeit sich geltend macht; die Richter fühlen, daß sie dadurch den Angeschuldigten selbst sehen, seine eigenen Erklärungen erfahren, Fragen

87 H.E. Löhr (1972), a.w., p. 97 t/m 101 en K. Gepperi (iS79), a.w., p. 61.

88 Zie S. Maas (1907), a.w., p. 24; E. Schmidt (1\%5), a.w., p. 324 en 325; H.E. Löhr (1972), a.w., p. 31 en 32 en K. Geppert (1979), a.w., p. 69.

89 A.R. von Feuerbach, Betrachtungen über die Oeffentlichkeit und Mündlichkeit der Gerechtigkeitspflege, Band I, Gießen 1821, p. 100.

90 A.R. von Feuerbach (1821), a.w., p. 165. 
an ihn stellen können, nicht selten bessere Materialien der Urtheilsfälung erhalten"' Het is de waarheidsvinding die bij Mittermaier bij het beginsel van mondelinge procesvoering voorop staat. Het wezen van dit beginsel bestaat volgens hem:

"in einer solchen Einrichtung des Verfahrens, da $\mathrm{B}$ alle Verhandlungen, auf deren Grund verurtheilt werden kann, daher die Anklage, alle Beweise, die Begründung derselben von den Richtern, welche das Urteil fällen sollen, selbst geführt werden und zwar so, daß die Richter ebenso wie der Ankläger und der Angeklagte die Benützung und Erhebung der Beweise beobachten und darauf wirken können. Zergliedert man dies Prinzip, welches passend auch das der Unmittelbarkeit genannt werden kann $^{92}$, so liegt darin 1) die Einrichtung, das der Angeklagte selbst vor seinen Richtern erscheine, auf die Beweiserhebung wirke und seine vertheidigung vortrage; 2 ) daß die Richter alle Zeugen, alle Sachverständigen, auf deren Aussagen verurtheilt werden soll, selbst sehen und hören; 3) da $B$ sie auf geeignete Weise jeden Zweifel durch Fragen an die Zeugen und Sachverständigen heben können; 4) daß nur auf den Grund mündlicher Vorträge des Anklägers und des Angeklagte oder seines Verteidigers entschieden wird" ${ }^{\text {193 }}$.

Belangrijk is dat Mittermaier in dit verband van het 'Prinzip der Unmittelbarkeit' spreekt.

\subsubsection{De hervorming van het Duitse strafproces naar Frans voorbeeld}

De Duitse wetenschap ging er aanvankelijk van uit dat men moest komen tot een hervorming op onderdelen van het oude geheime en schriftelijke proces. Zeer gauw kwam men echter tot het inzicht dat een principiële herziening vereist was en dat men daarbij buitenlandse voorbeelden in acht diende te nemen. De geestelijke aanzet voor de fundamentele verandering van het Duitse strafproces moet dan ook gezocht worden in de rechtsvergelijkende wetenschap, hoewel de eerste vertegenwoordigers daarvan in die tijd vaak gezien werden als ontevreden, onstuimige aanhangers der vernieuwing en verkapte demagogen en aanhangers van Frankrijk. Vooral in de eerste helft van de $19 \mathrm{e}$ eeuw, had het nieuwe Franse recht ten opzichte van het Engelse recht in de literatuur een duidelijk overwicht. Dat is niet zo vreemd. Immers, door de politieke situatie in de Duitse gebieden ter linkerzijde van de Rijn en de daaruit ontstane procesdualiteit was men met het Franse recht al veel beter bekend dan met het moeilijk kenbare, immers hoofdzakelijk ongecodificeerde, gewoonterecht uit Engeland. De vergelijking van het Franse strafproces met de praktijk van het

91 C.J.A. Mittcrmaicr, Dic Mündlichkeit, das Anklageprinzip, dic Oelfentlichkeit und das Geschworenengericht in ihrer Durchführung in den versehiedenen Gesetzgebungen dargestellt und nach den Forderungen des Rechts und der Zweckmäßigkeit mit Rücksicht auf die Erfahrungen der verschicdenen Länder, Stuttgart und Tübingen 1845, p. 110.

92 Cursivcring door de autcur.

93 C.J.A. Mittermaier (184.5), a.w., p. 246. 
tot dan toe gepraktiseerde Duitse strafproces, viel voor het Franse voorbeeld zo voordelig uit dat bij de bevolking en de politieke beslissingsbevoegden van die tijd, de keuze voor het Franse proces reeds gevallen was, nog voordat in het midden van de $19 \mathrm{e}$ eeuw ook het strafproces van Engeland in de hervormingsdiscussies betrokken werd. Daar kwam nog bij, dat aan het procesrecht uit het aangrenzende Frankrijk een met het Duitse proces gelijke historische ontwikkeling ten grondslag lag, zodat dit recht zich voor een receptie beter leende dan het Engelse ${ }^{24}$.

\subsection{Conclusie}

Gesteld kan worden dat halverwege de 19e eeuw op Duits grondgebied het oude geheime schriftelijke proces was overwonnen, althans in theorie ${ }^{95}$. Het inzicht was doorgedrongen dat in het belang van de waarheidsvinding een direkte persoonlijke confrontatie van de rechter met de bewijsmiddelen vereist was. Het vonnissende gerecht mocht zijn oordeel niet langer op schriftelijke aantekeningen van de onderzoeksrechter en ook niet op het relaas van de referent gronden. Van de rechter werd een direkte aanschouwing der bewijsmiddelen geëist. Daarnaast moest hem de mogelijkheid tot stellen van volledigheidsvragen worden geboden. De waardering van de werking van het uitgesproken woord als uitdrukking van de spontane gedachte en van de dramatische reproduktie van de relevante feitelijke momenten ging gepaard met een kwalitatieve geringschatting van het gebruik van reproducerende schriftelijke stukken. Dit leidde consequent tot de eis van een ononderbroken eindonderzoek en een zo spoedig mogelijke oordeelvelling, tot de noodzakelijkheid van de voortdurende aanwezigheid van de tot oordeelvelling geroepen personen en tot het postulaat van het persoonlijk verschijnen en de mondelinge verklaring van getuigen en deskundigen. Het belang van de waarheidsvinding vereiste bovendien dat het proces zou worden gevoerd in aanwezigheid van de beschuldigde.

\section{De Criminele Ordonnantiën van Philips II (1570) en de verdere ontwikkeling} van het Nederlandse strafproces tot aan de Franse overheersing (1810)

Wat de schets van de ontwikkeling van het strafproces in Nederlandse contreien aangaat, was, voordat de uitstap werd gemaakt naar de ontwikkeling van het Duitse strafproces, geconstateerd dat de Constitutio Criminalis Carolina hier te lande nauwelijks gelding heeft gehad. Dat wil overigens niet zeggen dat Karel V niet getracht heeft ook voor onze gebieden tot een grotere rechtseenheid op het gebied van het strafprocesrecht te komen. Reeds in 1531 werden in zijn opdracht alle gewestelijke 
gerechten aangeschreven met de opdracht om van alle gewesten het in grotere en kleinere rechtskringen geldende costumiere recht op schrift te stellen. Bij de maar al te zeer op hun privileges en oude historisch gegroeide rechten gestelde onderzaten bracht dit unificatiestreven van de landsheer echter grote ontstemming teweeg. Er werd dan ook weinig gehoor gegeven aan dit verzoek ${ }^{07}$.

Toch is de invloed van Karel $\mathrm{V}$ op de strafprocesrechtsvorming niet zonder belang geweest. De verschillende plakkaten, die door Karel V omtrent de lijfstraffelijke rechtsuitoefening zijn gegeven, mogen gezien worden als de eerste voorbereidingen tot het opstellen van een algemene manier van procederen in strafzaken ${ }^{\text {og }}$.

\subsection{Het unificatiestreven van Philips II}

Belangrijker nog dan Karel V voor de vorming van ons strafproces is zijn opvolger Philips II (1555-1598) geweest. Hij benoemde in 1567 de Hertog van Alva tot landvoogd en Gouverneur der Nederlanden en belastte hem onder meer met de opdracht om in onze gewesten een grotere rechtseenheid tot stand te brengen. De bestaande rechtsverscheidenheid was een doorn in het oog van de landsheer, die streefde naar de opbouw en inrichting van een gecentraliseerde eenheidsstaat onder zijn leiding ${ }^{\circ}$. In oktober 1569 gaf Alva daartoe wederom aan de verschillende rechtbanken het bevel het costumiere recht op schrift te stellen. Sommige rechtbanken hebben ondanks blijvende bezwaren aan deze opdracht voldaan. Het blijft echter de vraag of deze opgaven ook daadwerkelijk bij het opstellen der 'Criminele Ordonnantiën' van 5 en 9 juli 1570 in overweging zijn genomen. Gezien de korte tijd tussen het bevel en de afkondiging der Ordonnantiën lijkt dit niet waarschijnlijk ${ }^{100}$. Toch wordt aan de kop van de ordonnantiën uit naam van Philips II verklaard: "Hebben wy doen maecken, componeren ende oprichten sekeren styl, den gheschreven rechte aldermeest ghelyckende, ende t'ghene des wy by de forme ende maniere van procederen van herwaents over bevonden hebben het aller beste, claerste practicabelste ende rechtveerdelycxste ${ }^{\text {mor }}$.

De Criminele Ordonnantiën ${ }^{102}$ van Philips II, die aldus het resultaat waren van een groot opgezette poging om in de eerste plaats het strafprocesrecht en in de

96 Zic J.H. Drenth (1939), a.w., p. 193; J.P.H. de Monté Verloren en J.E. Spruit (1982), a.w., p. 199 en O. Moorman van Kappen, Dic Kriminalordonnanzen Philipps II. für die Niederlande im Verglecich zur Carolina, In: Strafrecht, Strafprozess und Reyeption, Frankfurt am Main 1984, p. 227 en 228.

97 Zic ook P. Traest (1992), a.w., p. 68.

98 J. de Bosch Kemper (1838), a.w., Ecrste decl, Inlciding, p. LXXXIII.

99 Zic O. Moorman van Kappen (1984), a.w., p. 229

100 O. Moorman van Kappen (1984), a.w., p. 231.

101 J. de Bosch Kemper (1838), a.w., Decl 1, Inleiding, p. LXXXIV en LXXXV.

102 De Criminele Ordonnantiën van Philips II bestaan nauwkeurig gezien uit drie verschillende, doch samenhangende ordonnantics: 1. 'Ordonnantic op het stuk der crimincle justitie' (81 artikelen), 2. 'Ordonnantie op de Cypiers ende bewaerders van vangenissen' ( 22 ongenummerde artikelen) en 3. 'Ordonnantie op den stijl van procedeeren in criminele zaken' ( 75 artikclen). 
tweede plaats ook het strafrecht ${ }^{103}$ in de Nederlandse gewesten te unificeren, hebben, ofschoon ingevoerd, niet lang formele rechtskracht gehad. De oorzaak hiervoor moet worden gezocht in het conflict dat was ontstaan tussen Philips II als landsheer en de Staten zijner gewesten over het wezen der soevereiniteit.

\subsubsection{De strijd over het wezen der soevereiniteit}

De landsheer en zijn uit ambtenaren bestaande omgeving namen het standpunt in dat de soevereiniteit niet slechts het traditionele complex rechten omvatte, welke tesamen de middeleeuwse landsheerlijkheid vormden, maar dat aan de soeverein als zodanig een in beginsel onbeperkte macht toekwam. De Staten daarentegen verdedigden de stelling, dat de landsheer alleen de beschikking had over die rechten, welke vanouds tot zijn landsheerlijkheid behoorden en waar de rechten der onderzaten tegenover stonden, uitgeoefend en bewaakt door onder meer de Statenvergadering. De soevereiniteitsopvatting van Philips II was voor de gewesten onaanvaardbaar, aangezien zij geregeerd wensten te worden met inachtneming van hun oude verkregen privileges, hun wetten en costumen en niet volgens een absolutistisch systeem. Het oude inheemse constitutionele beginsel van samenwerking tussen de landsheer en vertegenwoordigers van zijn onderzaten diende derhalve de grondslag van het bestuur te vormen. De Staten beriepen zich bovendien op het feit dat de landsheer bij het aanvaarden van de regering (1549) gezworen had de privileges, rechten en costumen van zijn onderzaten te zullen handhaven ${ }^{104}$. Toen de landsheer in juli 1570 ertoe overging om de Criminele Ordonnantiën aan de overheden van de verschillende gewesten toe te zenden met het bevel deze te laten afkondigen, stuitte dit op veel verzet. Ondanks de protesten heeft Philips II getracht de invoering van de ordonnantiën toch door te zetten. Doch als een daad van verzet hebben de Staten al in 1576 bij art. 5 van de Pacificatie van Gent de toepassing daarvan opgeschort en dit is nadien zo gebleven. Maar ondanks de bezwaren, die men tegen de Criminele Ordonnantiën had, hebben zij toch gedurende het gehele tijdvlak van de Republiek (15811795), door hun innerlijke waarde, hun invloed op de ontwikkeling van ons strafproces

103 Echter in tegenstelling to de Constitutio Criminalis Carolina, vinden we in de Criminele Ordonnantiën geen afzonderlijke delietsomschrijvingen. Dit is verklaarbaar: net zoals art. 55 van de ordonnantièn een algemene stijl van procederen in het vooruitzicht stelde (die enige dagen later ook daadwerkelijk werd uitgevaardigd), stelde art. 62 een verzameling van strafwetten, waarin alle bestaande edikten, ordonnantiën en plakkaten van strafrechtelijke aard in zouden zijn verwerkt, in het vooruitzicht. Blijkbaar was een dergelijke verzameling begin juli 1570 nog niet gereed en is deze door de politicke ontwikkelingen nadien nooit meer tot stand gekomen. Zic O. Moorman van Kappen (1984), a.w., p. 237.

104 Zie J.P.H. de Montć Verloren, J.E. Spruit (1982), a.w., p. 204 1/m 210 en O. Moorman van Kappen (1984), a.w., p. 229. 
doen gelden ${ }^{10.5}$. Daarom is het zaak kort stil te staan bij met name de 'Ordonnantie op den stijl van procedeeren in criminele zaken'.

\subsection{De Ordonnantie op den stijl van procedeeren in criminele zaken}

\subsubsection{Het initiatief tot vervolgen}

Droeg de Carolina nog (vage) sporen van het traditionele proces op basis van een aanklacht, uit art. VII van de 40 jaar jongere 'Ordonnantie op den stijl' valt af te leiden dat elk proces van ambtswege in gang moest worden gezet. Bovendien begon volgens de 'Ordonnantie op den stijl' ieder proces met een vooronderzoek.

\subsubsection{Bewijsvoering en positie van de beklaagde}

Wanneer de beklaagde tijdens het vooronderzoek een buitengerechtelijke bekentenis had afgelegd of wanneer de rechter op basis van getuigenverklaringen de zaak voor opgehelderd hield, kon worden volstaan met een verkort eindonderzoek, enkel om de officier (voorheen de baljuw, schout of drost) ${ }^{106}$ als klager van ambtswege de gelegenheid te geven zijn conclusie te nemen, waarna de aangeklaagde zonder meer kon worden veroordeeld (art. XVII ${ }^{107}$.

Ontkende de beschuldigde, dan diende het proces ordinair danwel extra-ordinair voortgezet te worden. Dit onderscheid tussen een ordinair dan wel extra-ordinair proces was oorspronkelijk voortgekomen uit het onderscheid tussen de vervolging op basis van een klacht en de later gebruikelijke ambtshalve vervolging, waarbij de klacht ontbrak. Vanaf de 16 e eeuw bestond het verschil tussen beide processen meer daarin dat een crimineel ordinair proces alleen plaatsvond wanneer er op de gewone wijze, met termijnen zoals in burgerlijke zaken gebruikelijk was, tussen de aanklager en aangeklaagde door procureurs bijgestaan, werd geprocedeerd. Dat kwam eigenlijk alleen nog voor, wanneer de zaak een rechtsvraag opleverde. Hoewel de naam anders doet vermoeden, was de extra-ordinaire procedure de gebruikelijke geworden. Deze procesvorm is te omschrijven als de kortere manier van procederen, die plaatsvond wanneer de schuld van de dader door getuigenbewijs, betrapping op heterdaad of bekentenis geacht werd vast te staan en het gepleegde delict verder

105 Zie M. van de Vrugt, De Criminclc Ordonnantien van 1570, Zutphen 1978, p. 155; P. Traest (1992), a.w., p. 70.

106 Zie J.P.H. de Monté Verloren, J.E. Spruit (1982), a.w., p. 135t/m 13K cn O. Moorman van Kappen (1984), a.w., p. $238 \mathrm{l} / \mathrm{m} 240$.

107 Zic J. de Bosch Kemper (1838), a.w., Eerstc Decl, Inlciding, p. XCIV en ( ). Mcorman van Kappen (1984), a.w., p. 242. 
geen bewijsmoeilijkheden gaf ${ }^{108}$. Het extra-ordinaire proces droeg een sterk inquisitoir karakter, in die zin dat het geheel in handen van de rechter lag. Het inquisitoire karakter van dit proces komt ook tot uitdrukking in het feit dat de beklaagde zich niet mocht laten bijstaan, hij was louter voorwerp van onderzoek naar de materiële waarheid ${ }^{100}$. De beklaagde diende zijn verdedigingsmiddelen meteen kenbaar te maken en ontlastende getuigen te noemen. Daarop werd door de rechter een termijn gesteld, waarbinnen zowel de officier als de aangeklaagde door getuigen of schrifturen hun standpunten dienden te bewijzen (art. XX). Aangaande het onderzoek binnen dic termijn, bepaalde de 'Ordonnantie op den stijl' dat de rechter ambtshalve of op verzoek van de officier of de beschuldigde nader onderzoek diende te doen, opnieuw de getuigen diende te horen en dat de beschuldigde daarbij aanwezig zou zijn of worden geïnformeerd over de namen van de getuigen die hem belasten (art. $\mathrm{XXI)}$.

De 'Ordonnantie op den stijl' kende verschillende voorschriften omtrent het getuigenverhoor en het verhoor van de beklaagde gedurende het proces (artt. XXII en XXIII). Daarbij werd herhaaldelijk bepaald, dat de rechters zowel de schuld als de onschuld van de beschuldigde dienden na te galan, daartoe ambtshalve getuigen dienden op te roepen om deze liever zelf te horen dan om dit over te laten aan commissarissen, die buiten de wettelijk omschreven gevallen, volgens de ordonnantie niet mochten worden benoemd (art. XXVII).

In het ordinaire proces daarentegen fungeerde de beschuldigde meer als tegenpartij van de officier van justitie. Dit proces werd hoofdzakelijk schriftelijk gevoerd, wilarbij de verdachte zich moest laten hijstaan door een procureur ${ }^{1: 0}$. Aan dit proces wijdt de 'Ordonnantie op den stijl' weinig aandacht, wellicht omdat dit proces als algemeen bekend werd verondersteld, maar misschien ook omdat de ordonnantie bepaalde dat normaliter de extra-ordinaire procedure gevolgd diende te worden ${ }^{11 !}$. Slechts bij uitzondering diende het ordinaire proces gevolgd te worden, namelijk wanneer de zalak juridisch erg gecompliceerd was ${ }^{112}$.

108 Zie J.H. Drenth (1939), a.w., p. 194 I/m 200; J. de Bosch Kemper (1838), a.w., Eerste Deel, Inleiding, p. XC. Zie voor een diepgaander analyse van het onderscheid tussen het ordinaire en extraordinaire proces: J. Monballyu, Het onderscheid tussen de civiele en de criminele en de ordinaire en de extraordinaire strafrechtspleging in het Vlaamse recht van de $16 \mathrm{e}$ eeuw, In: Misdaad, zoen en straf; aspecten van de middelccuwse strafrechtsgeschiedenis in de Nederlanden, o.r.v. H.A. Diederiks, H.W. Roodenburg, Hilversum 1991, p. 120 1/m 132.

109 J. de Bosch Kemper (1838), a.w., Eerste Decl, Inleiding, p. XCIV en XCV.

110 Zic ook J. Monballyu (1991), a.w., p. 125 en 126.

111 J. de Bosch Kemper (1838), a.w., Eerste Decl, Inleiding, p. XC en O. Moorman van Kappen (1984), a.w., p. 243.

112 Zie ook J. Monballyu (1991), a.w., p. 131. 
Reeds eerder werd vermeld dat het gebruik van de folter in die dagen in het strafproces een grote rol speelde. In navolging van de Carolina heeft ook de 'Ordonnantie op den stijl' getracht aan het misbruik hiervan paal en perk te stellen. Zo wordt tegenwoordig algemeen aangenomen ${ }^{113}$ dat volgens de Ordonnantiën het gebruik van de folter slechts was toegestaan, wanneer meer dan een vol half bewijs voorhanden was, maar minder dan een vol bewijs. In het laatste geval kon immers gelijk worden veroordeeld. Door de ondoorzichtige systematiek van de 'Ordonnantie op den stijl' echter - zo is bijvoorbeeld lang omstreden geweest welke bepalingen van toepassing waren op het ordinaire en welke op het extra-ordinaire proces - en omdat sommige procesrechtelijke bepalingen niet duidelijk waren - bijvoorbeeld art. XLII over de tortuur -, zal het niet verbazen dat de praktijk van die tijd een beeld liet zien dat geheel in strijd is met de geest van deze ordonnantiën ${ }^{114}$.

\subsection{De ontwikkeling van het strafproces na de Criminele Ordonnantiën}

Vanaf het einde van de 16e eeuw immers ontstaan in de praktijk grofweg twee soorten strafproces: het extra-ordinaire proces, waarbij de folter werd toegepast ongeacht of er sprake was van vol of half bewijs en die ten aanzien van landlopers en bedelatirs zelfs al bij voldoende aanwijzing werd aangewend ${ }^{115}$, en het ordinaire proces, dat ongeveer gelijk was aan het proces in burgerlijke zaken, maar ook kon resulteren in de toepassing van de folter ${ }^{116}$. De eerst genoemde vorm van proces was de gebruikelijke.

Verder groeit in de loop van de 17e eeuw de opvatting, dat slechts kon worden veroordeeld op basis van confessie ${ }^{117}$. En om die bekentenis te verkrijgen moest men haast wel overgaan tot toepassing van de pijnbank. De praktijk der $17 \mathrm{e}$ eeuw maakte zodoende de pijnbank tot onderdeel van het proces ${ }^{118}$.

Concluderend kan aldus worden vastgesteld, dat ondanks de in bepaalde opzichten vooruitstrevende geest van de theorie, zoals die tot uitdrukking kwam in de Ordonnantiën, de praktijk van het strafproces vele misstanden liet zien. Hoofdbestanddelen van het proces waren het verhoor van de beklaagde, zo nodig de confrontatie met getuigen, een niet-openbaar onderzoek zonder verdediging, waarbij de beschuldigde

113 Zie hierover M. van de Vrugt (1978), a.w., p. 147, Zo ook J. de Bosch Kemper (1838), a.w., Eerste

Deel, Inleiding, p. XCVI en O. Moorman van Kappen (1984), a.w., p. 244.

114 Zie hierover uitgebreid M. van de Vrugt (1978), a.w., m.n. p. $140 \mathrm{t} / \mathrm{m} 148$.

115 J. de Bosch Kemper (1838), a.w., Eerste Deel, Inleiding, p. CXXIII en J.H. Drenth (1939), a.w., p. 205.

116 Zie J. Monballyu (1991), a.w., p. 132.

117 J.H. Drenth (1939), a.w., p. 205. Zie ook J.L.M. Bock en J.F. Nijboer (1994), a.w., p. 41.

118 J.H. Drenth (1939), a.w., p. 202. 
louter voorwerp van onderzoek was en dat gericht was op het verkrijgen van een bekentenis hetgeen leidde tot een frequente toepassing van de pijnbank ${ }^{119}$.

\subsection{Herormingen}

Hoewel de vele misstanden anders doen vermoeden, was men toch niet blind voor de nadelen die er aan de gepraktiseerde wijze van procederen in criminele zaken verbonden waren. Maar bedacht moet worden dat Nederland destijds nog uit meerdere zelfstandige gewesten bestond en dat het nooit tot een unificatie van straf(proces)recht is gekomen. Daardoor zijn tussen de gewesten en ook binnen de gewesten tussen de verschillende steden, en tussen de steden en het platteland altijd verschillen in vormen van strafproces blijven bestaan, die in meer of mindere mate geheim en ook schriftelijk waren. De mate waarin men zich van overheidswege met de wijze van strafvordering bemoeide, verschilde van gewest tot gewest. In 1734 benoemden de Staten van Holland, waar men het verst was gegaan met de gewoonte om slechts op basis van bekentenis te veroordelen, een commissie om een revisie te bewerkstelligen van de Criminele Ordonnantiën, welke men als grondslag meende te moeten nemen. Evenals hij een commissie uit 1666 het geval was, hebben haar werkzaamheden echter tot niets geleid ${ }^{1 \times}$. Maar het inzicht dat er iets moest veranderen begon langzaam door te dringen. Deze ontwikkeling werd, evenals in Duitsland het geval was geweest, beïnvloed door de ideeën van de verlichting, die hun weg ook tot in onze gewesten hadden gevonden ${ }^{121}$. Verschillende commissies ter revisie van de strafvordering werden benoemd, maar hun werkzaamheden leidden niet tot nieuwe wetgeving.

Eerst de Bataafse omwenteling van 1795 zorgde voor enige belangrijke veranderingen op het gebied van het strafprocesrecht. Zo werd bij de Staatsregeling van 1798 de pijnhank afgeschaft voor de gehele Bataafse Republiek. Echter de unificatie op het gebied van het straf(proces)recht heeft nog tot 1809 op zich laten wachten, toen het 'Crimineel Wetboek voor het Koningrijk Holland' tot stand kwam. Het in dit wetboek geregelde proces was een gemoderniseerd Oud-Hollands strafproces. Hoewel ingevoerd ${ }^{122}$, heeft dit wetboek ten gevolge van de inlijving van Nederland bij Frankrijk (1810) niet lang rechtskracht gehad. De inlijving bij Frankrijk heeft ertoe geleid dat bij ons in 1811 de Code d'Instruction Criminelle van kracht werd ${ }^{123}$.

119 P. van Heijnsbergen, Het inquisitoire proces, In: Verspreide opstellen, Amsterdam 1929, p. 330.

120 J. de Bosch Kemper (1838), a.w., Eerste Deel, Inleiding, p. CXXIII 1/m CXXXIV en J.H. Drenth (1939), a.w., p. 206.

121 Zie in dit verband: Cesare Beccaria, Over misdaden en straffen, Antwerpen/Zwolle 1982, met name zijn daarin opgenomen vurige betoog tcgen het gebruik van de pijnbank, p. 79 t/m 90 .

122 Zic J.F. Nijboer, Naar een vrije bewijsrcgeling, D\&D 1982, p. 185.

123 Zie G.F.M. Bossers (1987), a.w, p. 32 cn 33. 


\section{De invloed van de Code d'Instruction Criminelle op de strafvordering in Neder-}

land

De Franse overheersing heeft maar tot 1813 geduurd's. Hoewel men gelijk aan de slag ging met de voorbereiding van een eigen nationaal Wetboek van Strafvordering, bleef ook na het vertrek van de Fransen de Code d'Instruction Criminelle van kracht. Wel werden er meteen enkele belangrijke aanpassingen uitgevoerd. Zo werden de jury-rechtspraak, de speciale Hoven en de openbaarheid van het onderzoek op de terechtzittingen als zijnde typisch Franse verschijnselen weer afgeschaft ${ }^{125}$. Deze maatregelen pasten bij de sfeer van die tijd, die werd gekenmerkt door heimwee naar het 'eigen' Oud-Hollandse recht en de afkeer van alles dat van Franse afkomst was ${ }^{12}$. Dat verklaart ook waarom het eerste wetsontwerp voor een nieuw nationail wethoek van strafvordering, dat werd ingediend op 17 januari 1815 , op enkele veranderingen na, dezelfde bepalingen bevatte als die voorkwamen in het derde boek van het Crimineel Wetboek van het Koningrijk Holland van $1809^{1}$. Het hoofdbeginsel van de hierin voorgestelde wijze van procederen was, dat niet naar aanleiding van de debatten ter terechtzitting, maar naar aanleiding van de verhoren voor de

124 Zie G.F.M. Bossers (1987), a.w., p. 86.

$125 \mathrm{Bij}$ het Souverein Besluit van 11 december 1813, Stb. 10, houdende bepalingen ten aanzien van de Lijfstraffelijke Regts-oefening, in de Verenigde Nederlanden werd in de artt. 16, 17 en 18 bepaald: "16. De Hoven van Assisen zullen voortaan worden gehouden zonder Jury, en de Regters in dezelve zullen, zoo wel met opzigt to de misdaad als tot de applicatic der Wet, uitspraak doen; 17. De gewone speciale Hoven worden, bij deze vernietigd en afgeschaft; de zaken dezelven gerenvoijeerd, zullen door de Hoven van Assisen worden afgedaan, aan welke cok voortaan gerenvoijeerd zullen worden alle zoodanige zaken, welke, volgens de dus verre nog in vigeur zijnde Wetten, aan speciale Hoven moesten verzonden worden; 18. Geene Criminele of Correctionele Audientien zullen in het openbaar gehouden worden, vóor het aanvangen der Pleidooijen, welke publiek moeten zijn; de arresten of vonnissen, met het geen daarbij behoort, moeten insgelijks in het openbaar worden gepronuntiëerd." Zie G.P.M. Bossers (1987), a.w., p. 91.

126 Volgens G.F.M. Bossers moet de verklaring van de afschaffing van de juryrechtspraak en de openbaarheid niet eenzijdig worden gezocht in de impopulariteit daarvan en de anti-Franse gevoelens, maar in de opvattingen van de opstellers van het besluit van 11 december 1813 zelf. De drie daarvoor verantwoordelijke personen waren allen leden van de rechterlijke macht. De jury die in 1790 en 1791 in het revolutionaiere Frankrijk was ingevoerd, was een anti-rechter instelling. De rechters werden daar toen algemeen beschouwd als de veroorzakers van de problemen in de strafrechtspleging. Door de jury af te schaffen, schaften de opstellers van het besluit tevens het symbool van het wantrouwen in de rechterlijke macht af. Volgens Bossers zagen de opstellers de openbaarheid van het onderzock op de zittingen van de hoven van assisen als een noodzakelijk bij de juryrechtspraak behorend iets. Zij vergaten echter, dat een openbaar onderzoek op de zitting ook mogelijk was zonder juryrechtspraak. Begrijpelijk, want dat hadden ze voor 1811 nog nooit meegemaakt. Eerst de juryrechtspraak had hun met openbare rechtspleging in aanraking gebracht. Zie G. F.M. Bossers (1987), a.w., p. 94.

127 Zie J.C. Voorduin, Geschiedenis en beginselen der Nederlandse Wetbocken, VI. deel, Wetboek van Strafvordering, Utrecht 1839, Inleiding, p. III. 
commissarissen gehouden, recht werd gesproken en dat alleen wanneer de beklaagde in een ordinair proces was ontvangen, de zaak ter terechtzitting werd bepleit ${ }^{12 x}$.

\subsection{Een commissie van Belgische rechtsgeleerden}

Het ontwerp van 1815 werd, na de vereniging van de noordelijke en zuidelijke provincies van het Koninkrijk ${ }^{12 \%}$, in handen gesteld van een commissie van Belgische rechtsgeleerden $^{130}$. Deze commissie had ernstige bezwaren tegen het voorstel. Zij merkte in haar verslag op dat dit voorstel de terugkeer betekende van het oude geheime proces en maakte zich vervolgens sterk voor het behoud van het openbare proces met zijn mondelinge procesbehandeling, zoals dat door de Fransen hier te lande was geïntroduceerd. $\mathrm{Zij}$ waarschuwde voor het herstel van het geheime proces, louter uit nationalistische overwegingen en pleitte ervoor vooral te behouden wat was gebleken goed te zijn. In haar verslag vinden we een uiteenzetting van de voordelen van het openbare mondelinge proces boven het geheime proces met zijn schriftelijke bewijsmateriaal. Zij schrijft ${ }^{\text {'3! }}$

"L' instruction orale et les débats qui s'établissement entre les témoins et l'accusé, ont pour objet d'approfondir toutes les circonstances du fait, d'éclairer tout les doutes, de dissiper toute équivoque et de produire l'evidence, autant qu'il est humainement possible.

C'est dans une audience publique, dans l'instruction orale, que l'accusateur, le plaignant, les témoins et l'accusé semblent porter leur concience à découvert; l'attention publique pèse sur eux tous; les passions, les ruses, le mensonge et limposture sont relevés tour à tour, et l'aspect imposant du public, est une entrave salutaire pour tous ceux, qui seraient tentés d'en user.

C'est dans une audience publique et orale, que se fait le véritable récolement des témoins, la vrai confrontation; c'est là que les témoins soutiennent ou modifient leurs déspositions primitives, d'après les explications dont elles sont susceptibles; c'est là que l'accusé et son conseil ont la latitude d'une juste défense; ils peuvent faire interroger les témoins par le juge; c'est là aussi que chaque juge peut éclaircir ses doutes, en interrogeant par lui-même et les témoins et l'accusé: c'est là enfin, que par les réflexions de tous, la vérité ne saurait échapper au juge ni au public, observateur redoutable pour tous.

Ainsi donc les juges, l'accusateur, les témoins, le public et l'accusé réclament également dans leur intérêt respectif, la publicité et l'instruction orale.

Le juge y inspirera le respect et la confiance par les soins et l'attention qu'il prendra pour se mettre en garde contre la haine, la vengeance, la ruse ou la faveur, et par ses efforts, constamment dirigés pour la manifestation de la vérité.

128 J.C. Voorduin, a.w., VII, deel, Wetboek van Strafvordering. Utrecht 1840, p. 3.

129 Zie G.F.M. Bossers (1987), a.w., p. 95.

130 J.C. Voorduin (1939), a.w., VI. decl, Inleiding p. III, G.F.M. Bossers (1987), a.w., p. 98.

$131 \mathrm{Zic}$ voor een uitgebreidere versie van het verslag van de Belgische commissic van 29 november 1819: J.C. Voorduin (1940), a.w., VII. deel, p. 4 I/rn 16. 
L'accusateur public, en développant avec force tous les moyens à l'appui de l'accusation, basés uniquement sur ce que l'instruction orale aura produit contre l'accusé, inspirera une terreur salutaire au méchant et une confiance utile à la Société.

Le témoin, en présence des magistrats, du public et de l'accusé, sentira l'impossibilité de déguiser la vérité, sans s'exposer au mépris général.

La Société entière sera sans inquiétude sur les décisions des tribunaux; elle aura tout vu, tout entendu et elle bénira les organes de la loi, par l'intégrité et l'impartiabilité qu'elle aura remarquées dans toutes leurs opérations. Le malfaiteur, s'il est présent à l'instruction, apprendra à connaître, que quels que soient les ruses, les détours du coupable, il ne peut échapper au glaive vengeur des lois.

L'accusé enfin, s'il est innocent, se rassurera; sa justification éclatera en presence du public; il n'aura pas à craindre qu'on n'attribue sa mise en liberté à la faveur, à la clémence ou à la corruption; la voix du peuple, comme celle des magistrats proclamera simultanément son innocence."

Duidelijk is dat deze Belgische Commissie de waarborg voor een optimale waarheidsvinding en daarmee voor een zo rechtvaardig mogelijke oordeelvelling, evenals vele Duitse rechtsgeleerden, vooral meende te vinden in de openbaarheid van de terechtzitting en de mondelinge behandeling van het proces.

Ondanks de bezwaren van de Belgische Commissie komt er echter in 1819 een nieuw wetsontwerp tot stand, dat op essentiële punten met het ontwerp van 1815 en het wetboek van 1809 overeenkwam ${ }^{132}$. Eerst in 1828 kwam een nieuw ontwerp tot stand dat aanmerkelijk anders van opzet was. Over het algemeen was men teruggekomen van het denkbeeld om de Franse wetgeving als van voorbijgaande aard te beschouwen $^{133}$. En naar aanleiding van de ontwikkelingen rond het nieuwe Wetboek van Strafrecht en de Wet op de organisatie der rechterlijke macht en het beleid der justitie meende men toch het nog in werking zijnde Code d'Instruction Criminelle aan dit nieuwe ontwerp ten grondslag te moeten leggen ${ }^{1.4}$. Dientengevolge was nu min of meer de indeling van de Code d'Instruction Criminelle gevolgd en werden vele artikelen daaruit overgenomen. Dat had tot gevolg dat het onderscheid tussen het ordinaire en extra-ordinaire proces uit de Oud-Hollandse rechtspleging in het ontwerp van 1828 niet werd gevolgd. In plaats daarvan werd de behandeling van zaken ter terechtzitting voorgesteld, na mondeling voor de rechter af te leggen verhoren en pleidooien.

\subsection{Openhaarheid en mondelinge procesvoering}

Vanaf dat moment werden, net zoals dat in Duitsland het geval was geweest, de openbaarheid en de mondelinge procesvoering als de positieve aspecten van het

132 J.C. Voorduin (1839), a.w., VI. deel, Inlciding, p. VII.

133 J.H. Drenth (1939), a.w., p. 210; G.F.M. Bossers (1987), a.w., p. 108.

134 Zic J.C. Voorduin (1839), a.w., VI. decl, Inleiding, p. IX en X. 
Franse strafproces beschouwd, die dienden te worden overgenomen. Over de concrete uitwerking daarvan, was men het nog niet helemaal eens. In het nieuwe ontwerp van 24 oktober 1829 werd, in afwijking van het ontwerp van 1828, bepaald dat de terechtzitting in strafzaken, zonder beperkingen, zou plaatshebben met open deuren ". Tijdens de openbare beraadslagingen van 18 maart 1830 werd hierover opgemerkt: "Men heeft dus eine nicuwigheid, dic. te gelijk met de Fransche wetgeving, hier te Lande w'as ingevoerd, dixh bij de herlening van ons volksbestaan was vemietigd, thans weder doen herleven. ${ }^{n 36}$ Uit dit citaat blijkt dat het pleit voor een openbaar en mondelinge procesbehandeling niet zonder slag of stoot werd beslist.

Maar het laatste ontwerp van 1836, dat tot stand kwam na de Belgische opstand, laat er geen misverstand over bestaan. De keuze voor een mondeling en openbaar proces was gemaakt. Dat blijkt ook uit hetgeen de Regering over dit ontwerp bij haar antwoord opmerkte. Zij stelde vast dat zij niet aan alle voorstellen tot verandering der voorgedragen ontwerpen had kunnen voldoen. Dat had dalarmee te maken:

"dat vele der bepalingen, waarvoor men anderen in de plaats wenschte gesteld zien, noodzakelijke gevolgen waren van, en in een dadelijk verband stonden met het vroeger door de Staten-Generaal aangenomen beginsel der orale debatten ${ }^{137}$, waarop het geheele systema van het wethoek van strafvordering berust, en dat derhalve al wat tegen dat stelsel strijdt, doch door sommige geachte leden als meer verkieslijk en beter, naar aanleiding van de vóor 1810 binnen deze Landen bestaan hebhende proces-orde beschouwd werd, niet weder ter sprake kon komen."134

Art. 170 van het Wetboek van Strafvordering van 1838 luidde uiteindelijk aldus: "Het regtsgeding zal, op straffe van nietigheid, worden gehouden overeenkomstig de voorschriften van artikel 20 der Wet op de regtelijke organisatie en het beleid der justitie". En dit art. 20 bepaalde: "In strafzaken zal het regtsgeding op de terechtzittingen in het openbaar worden gehouden op straffe van nietigheid, tenzij bij de wet anders mogt zijn bepaald, of de hooge raad, het hof, de regtbank, of het kantongeregt om gewichtige redenen, mogt bevelen, dat het regisgeding, geheel of gedeeltelijk met gesloten deuren zal plaats hebben."

\subsection{Onmiddellijkheid}

Zo werd in navolging van de Franse Code d'Instruction Criminelle het beginsel der oralité ook aan ons strafproces ten grondslag gelegd. De waarborgen voor een optimale waarheidsvinding werden ook bij ons in eerste instantie gezocht in een mondelinge

135 J.C. Voorduin (1839), a.w., VI. deel, Inleiding. p. XIII.

136 J.C. Voorduin (1840), a.w., VII. deel, p. 25.

137 Cursivering door de auteur.

138 J.C. Voorduin (1839), VI. deel, Inleiding, p. XXXII. 
en openbare procesbehandeling. In dit verband is illustratief hetgeen De Bosch Kemper opmerkt in zijn commentaar op art. 170 van het Wetboek van Strafvordering van 1838. Naar zijn mening dient dit artikel inderdaad in eerste instantie de openbaarheid, en met name de openbaarheid tot het publiek ${ }^{10}$. Maar hij vervolgt:

"Een tweede hoofdbeginsel, bij het onderzoek op de openbare terechtzitting, is, dat het onderzoek onmiddellijk plaats grijpe voor den regter, die het vonnis vellen moet in tegenwoordigheid van de beschuldigde. Dit beginsel van openbaarheid, in betrekking tot den regter, rust op de stelling, dat hoe meer eene bewijsvoering middellijk is, hoe meer gelegenheid er bestaat tot onjuiste beoordeling. Vanhier moeten alle getuigen voor den regter, die het vonnis vellen zal, mondeling gehoord worden, opdat de regter de verklaringen, in haar geheel kunne beoordelen. Ten einde de voordelen van deze onmiddellijke bewijsvoering te erlangen, behoort de regter op den toon, de gebaren, het meer of minder bedaarde of overijlde in de voordragt der getuigen te letten, en in éen woord niets te verzuimen op te merken van hetgene op de geloofwaardigheid der getuigen van invloed zoude kunnen zijn. Tegen deze voordelen van eene mondelinge voordragt voor den eindregter heeft men in het midden gebracht, dat de regter, door de getuigen en den beschuldigde zelf te horen, weleens door tranen van den ongelukkigen beschuldigde, door zijne drift, door zijn gunstig of ongunstig voorkomen, voor of tegen hem wordt ingenomen, en daardoor zijne onpartijdigheid verliest. Het is niet te ontkennen, dat deze nadeelen kunnen plaats grijpen, en vanhier rust eene sterke verplichting op den strafregter, om zich tegen deze indrukken te wapenen, ten einde de voordelen van eene onmiddellijke kennisneming, die de Wetgever heeft willen bereiken, niet vernietigd worden door de nadelen, welke daaruit kunnen ontstaan. Bij uizondering op het onmiddellijke onderzoek is bepaald, dat schriftelijke verklaringen van ambtenaren, op den eed bij de aanvaarding hunner betrekking afgelegd, als wettige bewijzen kunnen gelden, even als de schriftelijke rapporten van deskundigen, tot inlichting; doch van deze uitzondering behoort geen gehruik gemaakt te worden, zoo dikwijls te verwachten is, dat aan hun mondelinge verklaringen meerder licht kan worden ontleend, dan uit hunne processen-verbaal. Eene andere uitzondering op het mondelinge onderzoek voor den regter, in tegenwoordigheid van den beschuldigden, bestaat daarin, dat, bij wettige verhindering, de verklaringen van getuigen kunnen worden voorgelezen." ${ }^{\text {:40 }}$

Opvallend is hoe De Bosch Kemper in relatie tot de openbaarheid en de mondelinge procesvoering spreekt van een onmiddellijk onderzoek, een onmiddellijke bewijsvoering en een onmiddellijke kennisneming. Opmerkelijk is ook dat hij het voorlezen van verklaring als een uitzondering beschouwt van het monclelinge onderzoek en de begrippen 'mondeling' en 'onmiddellijk', evenals Mittermaier, min of meer als synoniemen hanteert.

139 J. de Bosch Kemper (1840), a.w., Tweede Deel, p. 388.

140 J. de Bosch Kemper (1840), a.w., Tweede Deel, p. 390 t/m 391. Cursiveringen in dit citaat zijn aangebracht door de auteur van dit proefschrift. 
$\mathrm{Er}$ is nog een belangrijk punt, dat hier de aandacht verdient. Wat de regeling van het bewijsrecht aangaat heeft de wetgever in het Wetboek van Strafvordering van 1838 immers niet het Franse voorbeeld gevolgd. Wat de bewijsregeling betreft werd aansluiting gezocht bij het Ontwerp van Wet van de Commissie van 1798, die destijds na de Bataafse omwenteling was benoemd tot vervaardiging van een nationale wetgeving $^{\mid 41}$. De belangrijkste vraag waarvoor deze commissie zich gesteld zag, was, of het onder het bereik van de wetgever valt om aan de rechter ten aanzien van het bewijs bindende regels voor te schrijven, of dat men de beoordeling van de vraag of de beschuldigde het hem telastegelegde feit heeft begaan, onvoorwaardelijk aan de zedelijke overtuiging van de rechter diende over te laten. Geïnspireerd door het Romeinse recht ${ }^{142}$ koos men voor de eerste variant. De waarborg voor de zekerheid van een bewijs werd niet gezocht in de louter innerlijke overtuiging van de rechter maar in de gronden waarop hij tot die overtuiging was gekomen. De wetgever werd in staat geacht enige algemene regels voor te schrijven, die de rechter in acht dient te nemen bij de beoordeling van de bewijsmiddelen, evenals enige verboden om bewijsmiddelen, waarvan de ondervinding de algemene onbetrouwbaarheid had aangetoond, als wettig en voldoende bewijsmiddel aan te nemen. Alleen de waardering van de bewijskracht der wettige bewijsmiddelen diende aan het oordeel van de rechter te worden overgelaten. Deze moet voor elk bijzonder geval beoordelen of tussen het aangevoerde wettige bewijsmiddel en de te bewijzen zaak zoveel verband bestaat, dat hij zich ook overtuigd acht dat de beschuldigde het hem telastegelegde feit heeft begaan ${ }^{1+3}$.

Deze hoofdbeginselen, die ten grondslag lagen aan het Ontwerp van Wet omtrent het bewijs van de Commissie van 1798 waren samengevat overgenomen in het Crimineel Wetboek van het Koningrijk Holland uit $1809^{14}$. Maar ook na de omwenteling van 1813 werden zij bijna onveranderd in de nieuwe ontwerpen overgenomen. In 1827 tenslotte werd de regeling van het bewijs - met de daaraan ten grondslag liggende keuze voor het negatief wettelijke bewijsstelsel - uit het ontwerp van het Wetboek van Strafrecht in het ontwerp van het Wetboek van Strafvordering overgeplaats ${ }^{145}$.

Onze wetgever had ingezien dat de Franse wetgever in de Code d'Instruction Criminelle weliswaar met veel zorgvuldigheid had gepoogd enige waarborgen te

141 J. dc Bosch Kemper (1840), a.w., Derde Decl, p. 484 en 491 en J.C. Voorduin (1840), a.w., VII. deel, p. 614 en 615.

142 J. de Bosch Kemper (1840), a.w., Derdc Decl, p. 485. Zie ook M. Damaska, Of Hearsay and its Analogues, In: Minnesota Law Revieuw 1992, vol. 76, p. 434 t/m 444: Het Romeinse recht kende reeds bepaalde restricties met betrekking tot het gebruik van bewijs, dat zijn inhoud niet aan richzelf ontleend, zoals de getuigenverklaring van horen zeggen.

143 J. de Bosch Kemper (1840), a.w., Derde Deel, p. 490.

144 Zie ook J.F. Nijboer (1982), a.w., p. 184 en 185.

145 J. de Bosch Kemper (1840), a.w., Derde Deel, p. 491 en J.C. Voorduin (1840), a.w., VII. deel, p. 621 . 
scheppen met betrekking tot de waarheidsgetrouwheid van verklaringen van getuigen. Zo was in de Code d'Instruction Criminelle bepaald dat getuigen de eed dienden af te leggen, dat geen bloedverwanten, eerlozen of kinderen jonger dan 15 jaar, onder ede mochten worden gehoord. Tegelijkertijd was het de gezworenen toegestaan om op de verklaringen van deze onbevoegden wel acht te slaan. Immers in art. 342 Code d'Instruction Criminelle werd aan de gezworenen voorgeschreven: "La loi ne demande pas compte aus jurés des moyens par lequels ils se sont convaincus; elle ne leur prescrit point de règles, desquelles ils doivent faire particulièrement dépendre la plénitude et la suffisance d'une preuve. "Daardoor verloren al deze bepalingen weer hun kracht, aangezien ook de getuigenis van onbeëdigden en onbekwamen tot dezelfde slotsom konden leiden, namelijk de zedelijke overtuiging der gezworenen ${ }^{146}$. Bovendien kende de Code d'Instruction Criminelle zoals we hebben gezien geen bepalingen die het verhoor van een getuige van de inhoud van zijn verklaringen afhankelijk stelde, zodat verklaringen van horen zeggen toelaatbaar werden geacht. Ook op die manier was het mogelijk dat verklaringen van onbeëdigden of onbevoegden het bewijs werden binnengesmokkeld.

Evenals de Franse Code d'Instruction Criminelle kende ons Wetboek van Strafvordering van 1838 een gesloten catalogus van vier wettige bewijsmiddelen: verklaringen van getuigen, schriftelijke bescheiden, de bekentenis en aanwijzingen. Zonder vervolgens op elk der bewijsmiddelen nader in te gaan, wil ik met een tweetal voorbeelden volstaan, om aan te tonen dat onze wetgever heeft getracht aan de onvolkomenheden van de Franse wetgeving het hoofd te bieden. Zo bepaalde het Wetboek van 1838 ten aanzien van de inhoud der getuigenissen in art. 398: "ledere afgelegde getuigenis moet lopen over feiten welke de getuige zelf gehoord, gezien of ondervonden heeft, en moeten daarbij tevens uitdrukkelijk worden opgegeven de redenen van wetenschap. Bijzondere meningen of gissingen, bij redenering opgemaakt, zijn geene getuigenissen." In overeenstemming met de opvatting dat de wet diende te verhinderen dat ongeoorloofd getuigen-materiaal (onbeëdigden of andere onbevoegden) voor het bewijs gebruikt zou kunnen worden, werd in de jurisprudentie de opvatting gehuldigd, dat de gekozen formulering in de weg stond aan het gebruik van een verklaring van horen zeggen als bewijsmiddel. Over het algemeen werden verklaringen van getuigen die daarin mededeling deden van wat anderen aan hen hadden medegedeeld als ontoelaatbaar beschouwd ${ }^{1+7}$. Ook ten aanzien van het bewijs door schriftelijke bescheiden is De Bosch Kemper van mening dat dit Wetboek ervan uitgaat dat "tot den aard van een schriftelijk bewijsstuk wordt vereischt, dat het hewijs in dat stuk zélf ligge opgesloten; zoodat schriftelijke verklaringen, ofschoon voor bevoegde ambtenaren

146 J.C. Voorduin (1840), a.w., VII. decl, p. 625 en 626.

147 Zie B.M. Taverne, Art. 398 van het Wetbock van Strafvordering MRT 1909. p. 116 c.v; 1A. Nederburgh, Hoofdstukken over strafvordering voor Nederlandsch Indie, tweede gedeclte: Het Bewijs, 's Gravenhage 1911, p. 141 c.v., A.J. Blok en L.Ch. Besier, Het Nederlandse st rafproces, Haarlcm 1925, deel II, p. 147, LCon's rechtspraak, literatuur en korte aantekeningen, tweede gedeclte - (art. 258-398), Leiden 1935, 4c druk, p. 1004 en 1005. 
afgelegd, alsmede onderhandsche brieven, waarin verklaringen worden afgelegd, niet alsschriftelijke bescheiden kunnen gelden: verklaringen van personen, welke eene daadzaak, in betrekking tot een misdrijf, gezien of ondervonden hebben, zijn getuigenissen, en kunnen niet dan in den vorm van getuigenissen door de regter aangenomen worden." 14

\section{Conclusie}

Vastgesteld kan worden dat het strafproces op Nederlands grondgebied tot aan de Bataafse omwenteling van 1795 zich heeft ontwikkeld van een openbaar, mondeling proces, waarin de rechter een geheel lijdelijke rol speelde, het initiatief van vervolging bij de aanklager berustte, de beklaagde subject van onderzoek was en bewijsmiddelen van formele aard waren tot een niet-openbaar, in meer of mindere mate schriftelijk proces, waarbij van rechtswege werd vervolgd, waarin de rechter het onderzoek naar de materiële waarheid in handen had, de beschuldigde object van onderzoek was en bewijsmiddelen weliswaar tot doel hadden de materiële waarheid aan het licht te brengen, maar weinig garanties daartoe boden.

De ontwikkeling van het strafproces op Duits grondgebied loopt min of meer volgens dezelfde lijnen. Onder invloed van het strafprocesrecht van de Constitutio Criminalis Carolina (1532) ontstond er een proces, dat zich bovenal kenmerkte door zijn schriftelijke en geheime karakter. Groeiende onvrede met dit proces leidde tot de hervormingsbeweging van de $19 \mathrm{e}$ eeuw. Er werd aansluiting gezocht bij de Franse Code d'Instruction Criminelle (1808) waaruit het idee van het débat orale werd overgenomen. Gezien de gebrekkige openhaarheid en het vergaand schriftelijke karakter van het tot dan toe gepraktiseerde Duitse proces is verklaarbaar waarom men in de openbaarheid en de mondelinge procesbehandeling dé waarborgen dacht te vinden voor een betere waarheidsvinding. Het zijn deze beginselen waaruit het onmiddellijkheidsheginsel is ontstaan. Mittermaier sprak in dit verband van het 'Prinzip der Unmittelbarkeit'.

Bij ons hebben de bestaande strafprocessen nooit tot dezelfde heftige reactie geleid als in de Duitse staatjes. Eerst door de Franse overheersing (1810-1813) kwamen wij in aanraking met de Code d'Instruction Criminelle en de daarin gemaakte keuze voor het débat orale. Maar ook bij ons werden openbaarheid en mondelinge procesbehandeling leidende procesbeginselen. Zonder dat dit door de wetgever dan wel in de literatuur uitdrukkelijk werd onderkend, kwamen deze beginselen in ons strafproces ten tijde van het Wetboek van Strafvordering van 1838 zelfs beter tot hun recht dan in het Franse strafproces uit die tijd. Dat was een gevolg van de door onze wetgever gemaakte keuze voor het negatief wettelijke bewijsstelsel. Deze keuze werd echter niet expliciet in verhand gebracht met de beginselen van openbaarheid en mondelinge procesbehandeling. Misschien dat mede daardoor in de hedendaagse

148 J. de Bosch Kemper (1840), a.w., Derde Decl, p. 549. 
literatuur nog steeds geen eenstemmigheid bestaat over wat het onmiddellijkheidsbeginsel nu eigenlijk inhoudt. 



\section{Begripsbepaling van het onmiddellijkheidsbeginsel}

\section{Inleiding}

In het vorige hoofdstuk werd beschreven hoe in de ontwikkeling van ons strafproces de kwaliteit van waarheidsvinding steeds belangrijker werd. Dit streven naar optimale waarheidsvinding is van invloed geweest op de wijze van bewijsvoering. Was de bewijsvoering aanvankelijk formeel van aard, geleidelijk aan stelt men meer inhoudelijke eisen aan wat als bewijs kan dienen. Vervolgens groeit ook het inzicht dat voor een optimale waarheidsvinding van belang is, hoe het bewijs ter kennis komt van de rechter. De rechter dient zijn oordeel niet louter te baseren op de schriftelijke stukken uit het vooronderzoek, maar zelf de bewijsmiddelen waar te nemen.

Deze laatste eis leek zich op te lossen in de beginselen van openbaarheid en mondelinge procesvoering, die als de waarborgen voor een betere waarheidsvinding werden beschouwd. Gaandeweg werd duidelijk dat er verband bestaat tussen deze procesbeginselen en het onmiddellijkheidsbeginsel. Maar de vraag blijft: "Welk verband?" Het gebrek aan begripsafbakening tussen deze afzonderlijke beginselen is er waarschijnlijk mede oorzaak van, dat tot op heden geen eenstemmingheid bestaat over wat het onmiddellijkheidsbeginsel inhoudt.

In dit hoofdstuk wordt gezocht naar een duidelijke begripsbepaling van het onmiddellijkheidsbeginsel. Daartoe wordt allereerst aandacht besteed aan de relatie tussen het onmiddellijkheidsbeginsel en het openbaarheidsbeginsel. Vervolgens ga ik in op de verhouding tussen het onmiddellijkheidsbeginsel en het beginsel van mondelinge procesvoering. Daarna wordt in beeld gebracht welke opvattingen er in de Duitse en Nederlandse literatuur zoal bestaan over de inhoud van het onmiddellijkheidsbeginsel. Aan het eind van dit hoofdstuk kom ik naar aanleiding van de voorafgaande analyse van de bestudeerde literatuur tot een nieuwe definitie van het onmiddellijkheidsbeginsel.

\section{De relatie tussen onmiddellijkheid en openbaarheid}

De roep om openbaarheid was een reactic op het oude geheime strafproces van weleer. Dat strafproces was geheim zowel jegens de beklaagde als jegens het volk. Uit dat oogpunt is het niet verwonderlijk dat men in de openbaarheid jegens de 
beklaagde en de openbaarheid jegens het volk belangrijke waarborgen dacht te vinden voor een beter proces. Maar welk verband bestaat er tussen openbaarheid en onmiddellijkheid? Aan de hand van oudere literatuur is getracht deze relatie aan het licht te brengen. Achtereenvolgens komt de opvatting van Von Feuerbach, De Bosch Kemper en Mittermaier aan de orde.

\subsection{De opvatting van Von Feuerbach over openbaarheid}

Een van de invloedrijkste voorstanders van de openbare strafrechtspleging uit de vorige eeuw was Anselm Ritter von Feuerbach (1775-1833). In zijn in 1821 verschenen studie "Betrachtungen über die Oeffentlichkeit und Mündlichkeit der Gerechtigkeitspflege", maakt hij onderscheid tussen de inwendige en uitwendige openbaarheid. De uitwendige openbaarheid heeft voor Von Feuerbach vooral een rechtspolitieke context. Hij legt een direkte relatie tussen "die Staatsverfassung und die Gerichtsverfassung": "Am ersten und klärsten offenbart es sich wenigstens als eine Unangemessenheit, wenn bei einer Verfassung, durch welche das Volk als am Staatsleben theilnehmende (moralische) Person zu staatsrechtlicher Bedeutenheit erhoben worden, die Gerichtigkeit, welche ganz eigentlich für das Volk und für die Gesammtheit des gemeinen Wesens besteht, von dem Volke zurückgezogen, dessen Augen entrückt ist, und in so ferne im Verborgenen ihr Ambt verrichtet."

De interne openbaarheid komt meer dan de externe openbaarheid ten goede aan de waarheidsvinding. Von Feuerbach acht het in strijd met de interne openbaarheid wanneer partijen niet bij het getuigenverhoor aanwezig mogen zijn, maar slechts kennis kunnen nemen van het proces-verbaal waarin de verklaringen zijn opgenomen. Aan het argument dat de afwezigheid van de aangeklaagde de waarheidsgetrouwheid van getuigenverklaringen ten goede zou komen, kent hij geen waarde toe: "Fürchtet man die Befangenheit des Zeugen, warum fürchtet man nicht noch weit mehr von dem Leichtsinn, von der stumphen Unaufmerksamkeit und lässigen Gleichgültigkeit desselben? Hat etwa der Zeuge nicht weit mehr Ursache seine Gedanke zu schärfen, sich vorsichtiger zu erklüren, seine Worte bedächtlicher nach der Walırheit abzumessen, wann er demjenigen gegenüber steht, über welchen jetzt seine Aussage entscheidet?"2 Von Feuerbach rekent de direkte confrontatie (onmiddellijkheid?) tussen de getuigen en de aangeklaagde tot de inwendige openbaarheid.

1 A.R. von Feuerbach, Betrachtungen über die Oeffentlichkeit und Mündlichkeit der Gerechtigkeitspflege, Band I, Gießen 1821, p. 9 en 10.

2 A.R. von Feuerbach (1821), a.w., p. 107. 
Aandacht verdient ook hetgeen De Bosch Kemper in zijn commentaar op het Wetboek van Strafvordering 1838 schrijft over openbaarheid. De openbaarheid van de rechtspleging bestaat volgens hem in drieërlei opzichten. Hij maakt een onderscheid tussen de openbaarheid ten aanzien van aangeklaagde, ten aanzien van de rechter en ten aanzien van het publiek?.

De Bosch Kemper noemt de rechtspleging ten aanzien van de aangeklaagde openbaar, wanneer bewijzen waarop de rechter zijn oordeel zal baseren in aanwezigheid van de aangeklaagde worden vergaard. In dat geval worden bijvoorbeeld alle getuigen in het bijzijn van aangeklaagde door de rechter gehoord.

Naar gelang de rechter onmiddellijk of meer middellijk tot zijn overtuiging komt, is volgens De Bosch Kemper de rechtspleging ten aanzien van de rechter meer of minder openbaar. De vraag over het al dan niet wenselijke der openbaarheid ten aanzien van de rechter komt volgens deze schrijver aldus hierop neer, of de oordelende rechter zelf zal onderzoeken en lost zich daarom bijna geheel op in de vraag naar de voorkeur voor een mondelinge dan wel schriftelijke bewijsvoering. Hier legt Bosch Kemper een relatie tussen de openbaarheid ten aanzien van de rechter en mondelinge procesbehandeling.

Met betrekking tot de openbaarheid ten aanzien van het publiek wijst De Bosch Kemper erop dat voorstanders van deze openbaarheid denken dat dit het beste middel is, om bij het volk vertrouwen in een goede rechtsbedeling op te wekken en het rechtsgevoel te verlevigen. Deze openbaarheid draagt bij aan de doelstellingen van de strafwet (generale en speciale preventie). Bovendien vormt deze openbaarheid een prikkel tot nauwgezet optreden van de rechterlijke ambtenaren.

\subsection{De betekenis van de openbaarheid volgens Mittermaier}

Waarschijnlijk heeft De Bosch Kemper de driedeling der openbaarheid ontleend aan Mittermaier, die zich in dezelfde zin over de openbaarheid had uitgelaten'. In dit verband is opmerkelijk dat Mittermaier later over de relatie tussen openbaarheid en en mondelinge procesvoering ofwel onmiddellijkheid schrijft: "Die Aufjassung der richtigen Bedeutung der Oeffentlichkeit im Strafprozesse uurde vielfach dadurch gehindert, daß man Vorzüge, welche nur auf Rechnung des mündlichen, unmittelhar vor den urtheilenden Richtern geführten Verfahrens zu setzen sind, als Vortheile der

3 J. de Bosch Kemper, Wetboek van Strafvordering, naar deszelfs beginselen ontwikkeld, $c n$ in verband gebragt met de algemene regtsgeleerdheid, Eerste Deel, Amsterdam 1838, Inleiding, p. XXIV $\mathrm{t} / \mathrm{m}$ XXVI.

4 Zie H. Stegmaier, Die Frage der Unmittelbarkeit bei der Behandlung der Zeugen und Sachverständigen in der Gesetzgebung und im Schriftum des reformierten deutschen Strafprozesses vor der Reichsstrafprozeßordnung, Gießen 1935, p. 16. 
Oeffentlichkeit schilderte (..). ${ }^{.6}$ In een voetnoot bij dit citaat staat: "Auch der Verfasser dieser Schrift kann sich von dem Vorwurf dieser Verwechslung nicht frei machen. "Volgens Mittermaier komt de externe openbaarheid ten goede aan de legitimatie van de wet en het oordeel: "Die Staatsregienung muß wünschen, daß sich bei den Bürgern, welche nach den Gesetzen leben und sie achten sollen, das Bewußtseyn ausspreche, daß das Gesetz weise ist, und in seiner Anwendung als solches sich bewähre, daß insbesondere das Strafgesetz so weise abgefaßt sey, daß kein Unschuldiger als Opfer desselben falle, und kein Schuldiger seiner Strafe entgehe, daß Jeder aber auch nurvon dergerechten Strafe betroffen werde." Vervolgens legt hij de relatie tussen openbaarheid en onmiddellijkheid: "Hierzu aber gehört, daß das Volk nicht blos erfahre, daß ein Angeschuldigter verurtheilt ist, sondern auch, daß es erfahre, auf welche Thatsachen und Beweise die Verurtheilung erfolgte, ob die Verhandlung die Bürgschaft der höchsten Sorgfalt in der Ausmittelung der Wahrheit und einer Thätigkeit liefert, bei welcher dem Angeschuldigten die ausgedelnteste Vertheidigung möglich gemacht wurde. ${ }^{\text {n }}$ In deze visie van Mittermaier omvat externe openbaarheid de onmiddellijkheid. Een strafproces dat onvoldoende tegemoet komt aan het onmiddellijkheidsbeginsel doet afbreuk aan de externe openbaarheid van de strafrechtspleging. Onmiddellijkheid vormt een noodzakelijke voorwaarde voor de externe openbaarheid. Vanuit deze visie is verklaarbaar dat men als reactie op het oude geheime en schriftelijke strafproces van weleer, via het meerdere (eis van openbaarheid) ook het mindere (eis van onmiddellijkheid) trachtte te bereiken.

Volgens Mittermaier draagt de externe openbaarheid ook bij aan de waarheidsvinding. Tijdens een openbare terechtzitting kunnen uit het publiek nieuwe getuigen opstaan die zonder openbaarheid niet zouden zijn gevonden. Bovendien worden getuigen ter terechtzitting door de externe openbaarheid gestimuleerd tot waarheidsgetrouwe verklaringen, aangezien zij er rekening mee moeten houden dat temidden van het publiek personen aanwezig zijn, die hen op leugens kunnen betrappen.

Verder noemt Mittermaier nog een aantal andere voordelen van de externe openbaarheid. Van de opvatting dat het volk door middel van de externe openbaarheid controle kan uitoefenen op de strafrechtspleging heeft Mittermaier geen hooggespannen verwachtingen: "Niemand kann im Emste glauben, daß eine durch Zufall gebildete, vielleicht aus wenig urheilsfähigen Menschen bestehende, oft kleine Anzahl von Zuhörem eine Controle über die Rechtspflege wirksam ausüben kann. Das Untheil dieses Publikums überdie Zweck-oder Rechtmäßigkeit der Verhandlungen kann doch keinen rechtlichen Einfluß auf den rechtlichen Bestand des Prozesses üben, und die Zeichen des Beifalls

5 C.J.A. Mittermaier, Die Mündlichkeit, das Anklageprinzip, üie Oeffentlichkeit und das Geschworenengericht in ihrer Durchführung in den verschiedenen Gesetzgebungen dargestellt und nach den Forderungen des Rechts und der Zweckmäßigkeit mit Rücksicht auf die Erfahrungen der verschiedenen Länder, Stuttgart und Tübingen 1845, p. 333.

6 C.J.A. Mittermaier (1845), a.w., p. 334 en 335.

7 C.J.A. Mittermaier (1845), a.w., p. 355.

8 C.J.A. Mittermaier (1845), p. 337 en 338. 
oder des Mißfallens einses Publikums, dessen Beurtheilungskraft und Willensreinheit oft sehr zu bezweifeln ist, werden die Richter nicht irre machen." op: "Dagegen erscheint nach psychologischen Gesetzen die Oeffentlichkeit als neuer Antrieb zur gewissenhafteren Plichterfüllung für die Richtern, für die Beamten der Staatsbehörde und für die Verteidiger; sie gibt den Verhandlungen eine höhere Würde, die wieder wohlthätigen Einflu $\beta$ hat. ${ }^{\text {no }}$

Tot de voordelen van de externe openbaarheid rekent Mittermaier ook het opgewekte vertrouwen dat de werkelijk schuldige zijn straf niet ontloopt ${ }^{11}$, dat de openbaarheid bijdraagt aan de rechtskennis van het volk ${ }^{12}$ en dat de onschuldige zich door middel van de openbaarheid voor het volk kan rehabiliteren ${ }^{13}$.

Mittermaier beperkt zich bij de openbaarheid in relatie tot de onmiddellijkheid tot de externe openbaarheid. De eisen die volgens Von Feuerbach voortvloeiden uit het interne openbaarheidsbeginsel worden door Mittermaier gezien als behorende tot het wezen der mondelinge procesvoering. In de Duitse literatuur ging men er in navolging van Mittermaier allengs toe over zich in relatie tot de onmiddellijkheid steeds meer te concentreren op het beginsel der mondelinge procesvoering ${ }^{14}$.

\subsection{Conclusie}

Het lijkt erop dat Von Feuerbach interne openbaarheid en onmiddellijkheid als identieke begrippen hanteert. Een relatie tussen de externe openbaarheid en onmiddellijkheid lijkt er in zijn opvatting niet te bestaan.

Volgens De Bosch Kemper is een strafproces voor de aangeklaagde en de rechter meer openbaar naar mate zij de oorspronkelijke bewijsmiddelen zelf kunnen aanschouwen. Openbaarheid en onmiddellijkheid worden in die zin door De Bosch Kemper als identieke begrippen beschouwd.

Mittermaier daarentegen hanteert beide begrippen meer in de zin van oorzaak en gevolg. Zonder onmiddellijkheid geen externe openbaarheid.

\section{De verhouding tussen de onmiddellijkheid en de mondeling procesvoering}

Het oude strafproces was niet alleen geheim maar kenmerkte zich bovendien door zijn schriftelijke karakter. Naast de openbaarheid werd daarom door de Duitse hervormingsbeweging van de $19 \mathrm{e}$ eeuw in de mondelinge procesvoering een belangrijk

9 C.J.A. Mittermaier (1845), a.w., p. 338.

10 C.J.A. Mittermaier (1845), a.w., p. 338 en 339.

11 C.J.A. Mittermaier (1845), a.w., p. 340.

12 C.J.A. Mittermaier (1845), a.w., p. 342.

13 C.J.A. Mittermaier (1845), a.w., p. 342.

14 H. Siegmaier (1935), a.w., p. 17. 
wapen gezien tegen de processuele misstanden van weleer. In de beschouwingen over de mondelinge procesvoering uit die tijd duiken steeds weer termen op als 'onmiddellijk' en 'onmiddellijkheid'. Mittermaier gaat er zelfs toe over het beginsel van de mondelinge procesvoering gelijk te stellen aan het onmiddellijkbeginsel. Geleidelijk groeit het inzicht dat beide beginselen niet identiek zijn, maar dat er tussen beide wel een relatie bestaat. De vraag is welke?

Allereerst wordt stilgestaan bij de opvatting van Von Feuerbach over de inhoud van het beginsel van de mondelinge procesvoering. Vervolgens komen de ideeën van Mittermaier over het belang en de betekenis van het beginsel van de mondelinge behandeling aan de orde. Hoewel voor Mittermaier de relatie tussen het beginsel van de mondelinge behandeling en het onmiddellijkheidsbeginsel duidelijk was zij waren immers in zijn opvatting identiek -, is het belangrijk om zijn opvatting over het beginsel van de mondelinge behandeling te leren kennen. Daaruit kunnen belangrijke inzichten worden opgedaan over de betekenis van het onmiddellijkheidsbeginsel. Vervolgens wordt ingegaan op het verschil tussen het beginsel van de mondelinge procesvoering en het onmiddellijkheidsbeginsel volgens Maas. De opvatting van deze Duitse rechtsgeleerde uit het begin van deze eeuw is interessant omdat hij gezien kan worden als een representant van een tijd waarin de Duitse literatuur een onderscheid gaat maken tussen het onmiddellijkheidsbeginsel en het beginsel van mondelinge procesvoering. Ten slotte wordt in beeld gebracht wat volgens Geppert, als een vertegenwoordiger van de huidige Duitse literatuur, de betekenis en inhoud is van het beginsel van de mondelinge procesvoering en wat de relatie is tussen dit beginsel en het onmiddellijkheidsbeginsel.

\subsection{De opvatting van Von Feuerbach over het beginsel van de mondelinge procesvoe- ring}

"An der Verwirmung des Streits über die Oeffentlichkeit der Rechtspflege hatte, unter anderem, auch die nicht seltene Vermischung der Oeffentlichtkeit mit der Mündlichkeit keinen geringen Antheil. Sprach man won jener, so wurde sogleich auch diese stillschweigend mitverstanden, gleichsam als wäre die eine in der andern enthalten oder als wären mindestens beide auf unzentrennliche. Weise mit einander verbunden ${ }^{m s}$, zo schrijft Von Feuerbach. Volgens hem is echter een mondelinge behandeling van het onderzoek ter terechtzitting zonder openbaarheid evenzo goed denkbaar als een openbare terechtzitting zonder mondelinge procesbehandeling: het eerste, wanneer partijen achter gesloten deuren onmiddellijk en mondeling met het gerecht in contact staan en van deze mondeling het oordeel vernemen; het tweede, wanneer het onderzoek ter terechtzitting met open deuren plaatsvindt op basis van de stukken van het vooron- 
derzoek en het oordeel alleen hierop gebaseerd wordt ${ }^{16}$. Eerder werd vastgesteld dat Von Feuerbach de direkte confrontatie tussen de getuigen en de aangeklaagde rekent tot de inwendige openbaarheid. Hier lijkt hij zich alleen uit te laten over de externe openbaarheid.

Ondanks de door Von Feuerbach geconstateerde onduidelijkheid besteedt hij vervolgens weinig aandacht aan de onderlinge verhouding van de openbaarheid en de mondelinge behandeling, omdat: "Haufiger noch als das Untereinandermengen der Mündlichkeit und der Oeffentlichkeit, ist die Venwirnung jenes Begriffs in seinem Gegensatze mit der Schriftlichkeit. ${ }^{m 7}$ Mondeling is in de ogen van deze auteur de mededeling die de weg aflegt van mond naar oor. Schriftelijk daarentegen is het woord dat wordt geschreven en gelezen ${ }^{18}$.

"Wer nicht blos unmittelbar aus dem Geist, sondern von dem Papier zu einem andern spricht, steht mit diesem in mündlicher Verhandlung: wer einem zweiten in die Feder sagt, was ein dritter erst durch diese Schrift erfahren soll, verhandelt mit diesem schriftlich." ${ }^{19}$ (..) "Werden unter der Leitung eines Abgeordneten des erkennenden Gerichts vorlaufig unter den Partheien Schriften gewechselt; so ist gleichwohl an dem Daseyn mündlicher Rechtspflege nicht zu zweifeln, wenn nur, sobald es zur Entscheidung kommt, die Partheien vor dem erkennenden Gerichte selbst ihre Sache mündlich verhandeln. Hingegen wird die Rechtspflege eben so unbezweifelt eine schriftliche genannt werden müssen, wenn zwar die Partheien sich vor jener Mittelperson mündlich erklären, das urtheilende Gericht aber nur durch schriftliche Mitteilungen hiervon in Kenntniß gesetzt wird. ${ }^{\text {nat }}$

Volgens Von Feuerbach heeft het onderscheid tussen een mondelinge dan wel schriftelijke procesbehandeling alleen betrekking op de communicatie tussen partijen en het oordelende gerecht:

"Sind es die Partheien (oder - was gleichviel - ihre An wălte), welche, in dem Begriff von mündlicher oder schrifticher Rechtspflege als dem Gericht sich mittheilend gedacht werden mủssen; so liegt es ganz ausser den Grenzen der Aufgabe zu unterscheiden: auf welche Art etwa durch eine andere, von den Partheien oder ihren Anwälten verschiedene Person deren Angelegenheit zur Kenntniß des Gerichtes gebracht wird ${ }^{21}$. (.) Ob daher Zeugen und Sachverständige unmittelbar vor dem urtheilenden Gericht erscheinen, oder aussergerichtlich (vor einem Gerichtsbevollmächtigten) ihre Aussagen zum Gerichtsbuch geben: bestimmt blos einen Unterschied der verschiedenen Formen des mündlichen Verfahrens, nicht aber den allgemeinen Begriff desselben. ${ }^{\text {n2 }}$

16 A.R. von Feucrbach (1821), a.w., p. 195.

17 A.R. von Feuerbach (1821), a.w., p. 196.

18 A.R. van Feucrbach (1821), a.w., p. 196.

19 A.R. von Feuerbach (1821), a.w., p. 197.

20 A.R. von Feucrbach (1821), a.w.. p. 198 en 199.

21 A.R. von Fcucrbach (1821), a.w., p. $197 \mathrm{cn} 198$.

22 A.R. van Feucrbach (1821), a.w., p. 200. 
Geconcludeerd kan worden dat van Von Feuerbach in zijn opvatting niet helemaal consistent is: het mondelinge dan wel schriftelijke karakter van het strafproces betreft louter de communicatie tussen partijen en de rechter en heeft niets van doen met de wijze waarop het bewijs ter kennis komt van de rechter. Tegelijkertijd betreft onmiddellijkheid en dus de wijze waarop het bewijs ('die Angelegenheit einer anderen Person') ter kennis van de rechter komt, een vorm van mondelinge procesvoering.

\subsection{Het belang en de betekenis van het beginsel van de mondelinge procesvoering} volgens Mittermaier

Volgens Mittermaier was het beginsel der mondelinge procesvoering gelijk aan het beginsel der onmiddellijkheid. Hij schrijft: "Der Grundsatz der Mündlichkeit, welches passend auch das der Unmittelbarkeit genannt werden kann, besteht in einer solchen Einrichtung des Verfahrens, daß alle Verhandlungen, auf deren Grund verurtheilt werden kann, daher die Anklage, alle Beweise, die Begründung derselhen von den Richtem welche dus Urtheil fällen sollen, selbst geführt werden und zwar so, daß die Richter ebenso wie der Ankläger und der Angeklagte die Benützung und Erhebung der Beweise beobachten und darauf wirken kïnnen. ${ }^{123}$

Het beginsel van de mondelinge procesvoering heeft volgens Mittermaier zeer vele voordelen, waarvan de belangrijkste zijn:

1. "Nur durch sie erlangen die Richter die Gewißheid, daß die Aussagen der Angeklagten und der Zeugen treu, vollständig und in dem richtigen Zusammenhange zu ihrer Kenntni $\beta$ gelangen. ${ }^{21}$ Daarbij merkt Mittermaier op dat het niet aangaat de onderzoeksrechter van kwader trouw te betichten. Elke reproduktie van bewijs brengt immers een kleuring van de feiten met zich ${ }^{25}$.

2. "Nur das mündliche Verfahren gibt dem Richter die Möglichkeit, durch geeignete Fragen an die Angeklagten und die Zeugen alle $Z$ weifel zu beseitigen, die sonst mehr oder minder zurückgeblieben wären und die Verurtheilung gehindert haben würden. Nur derjenige, welcher das Urtheil zu fällen hat, ist im Stande, zu erwägen, welche Materialen er bedarf, um urtheilen zu können. ${ }^{n 6}$

3. "Die gehörige Würdigung der Individualität der Angeklagten und der Zeugen ist nur bei dem mündlichen Verfahren möglich." Het is noodzakelijk dat de rechter de getuige zelf ziet: "das ganze Benehmen des Aussagenden, der Emst oder die Flüchtigkeit seiner Rede, die Beharrlichkeit in den Aussagen oder sein beständiges Schwanken 
u. A. geben dem Richter die Möglichkeit, die. Glaubwürdigkeit des Zeugen zu beurtheilen. ${ }^{1 m}$

4. "Das Vertheidigungsrecht des Angeklagten erhält erst in der mündlichen Verhandlung seine wahre Bedeutung. Nur darin ist es möglich, daß der Vertheidiger auf die Beweisfühnung einwirke, durch Fragen an die Zeugen oder Sachverständigen ihre Aussagen über Umstände veranlasse, die auf die Urtheilsfällung einwirken, und die in der Voruntersuchung aufgezeichneten Aussagen bekämpfe oder berichtige. Nurbei dem mündlichen Verfahren ist der Vertheidiger in den Stand gesetzt, die Schlußfordeningen, welche der Ankläger aus gewissen Umständen ableitet, sogleich zu zerstören und dem nachtheiligen Eindrucke auf die Richter vorzubeugen. ${ }^{\text {ns }}$

5. "Nur das beständige Zusammenwirken aller lebendig vor der Seele der Richter die Umstände des Verbrechens reconstuirenden Aussagen, das rasche Ineinandergreifen der Ergebnisse der Beweismitteh die Schlag auf Schlag auf einander folgenden Aussagen des Zeugen, verbunden mit den Erklärungen des Angeklagten über jeden Punkt regen nachhaltig die geistige Thätigkeit der Richter an, erhalten ihn in der nothwendigen geistigen Spannung und gewähren ein Bild des Ergebnisses der Verhandlungen, wie keine Relation des ausgezeignetsten Referenten es zu geben im Stande ist. ${ }^{\text {mo }}$

Als laatste belangrijk voordeel van de mondelinge procesvoering dat hier niet onvermeld mag blijven, noemt Mittermaier:

6. "(..) das auf den Angeschuldigten selbst ein weit stärkerer Eindruck henorgebracht und das Gefühl der Beruhigung erzeugt wird, wenn er sicher ist, daß er selbst vor seinen Richtern seine ganze Denk- und Vorstellungsweise und die daran geknüpfte Vertheidigung vortrage konnte, daß er Alles, was er gegen die früheren Untersuchung einzuwenden, vortragen durfte, und auf die Erhebung der Beweise selbst wirken konnte. Auch das Vertrauen des Volkes zur Gerechtigkeit des Strafurtheils steigt, wenn man weij3. welche ausgedehnten sichernden Befugnisse der Vertheidigung dem Angeklagten gegeben wurden. ${ }^{\text {"30 }}$

3.3 Het onderscheid tussen het beginsel van de mondelinge procesvoering en het onmiddellijkheidsbeginsel volgens Maas

Dat Mittermaier de begrippen mondelinge procesvoering en onmiddellijkheid als synoniemen hanteerde is uit historisch oogpunt begrijpelijk. Het Oud-Duitse Strafproces ten tijde van het ontstaan van de hervormingsbeweging kenmerkte zich vooral door zijn schriftelijke karakter. De rechter oordeelde louter op grond van schriftelijk

27 C.J.A. Mittermaicr (1845), a.w., p. 251

28 C.J.A. Mittermaier (1845), a.w., p. 251 en 252.

29 C.J.A. Mittermaier (1845), a.w., p. 252.

30 C.J.A. Mittermaier (1845), a.w., p. 260. 
bewijsmateriaal, zonder zelf ooit de aangeklaagde en/of getuigen te zien en te horen. Als reactie op die praktijk ging men ertoe over van de rechter te eisen dat hij zijn beslissing baseert op eigen waarneming en/of ondervraging van de bewijsmiddelen. Met de eis van mondelinge procesvoering leek men een heel eind te komen. Maas zegt hierover: "Spricht man in der Reformliteratur von Mündlichkeit, so will man damit eben ausdrücken, dass die Auskunftspersonen dem Erkenntnisgericht mündlich ihre Wahmemungen mitteilen und letztere nicht erst durch das Protokoll des Inquirenten oder das Referat des Referenten zur Kenntnis des erkennenden Richters kommen. Insoweit ist der Begriff der Mündlichkeit sicher zutreffend. Dreht es sich aber um Augenscheinsobjecte und Urkunden, so ist natürlich mit diesem Begriff der Mündlichkeit nichts mehr anzufangen. Hier half man sich dann mit Wendungen wie "Mündlichkeit, passend Unmittelbarkeit" oder "Mündlichkeit besser Unmittelbarkeit". ${ }^{\text {(1) }}$

Dat mondelinge procesvoering en onmiddellijkheid geen identieke begrippen zijn kan volgens Maas eenvoudig door middel van een aantal voorbeelden worden duidelijk gemaakt. In een proces waarbij de rechter van de verdachte, getuigen of deskundigen door een gordijn is afgescheiden is weliswaar sprake van een mondelinge behandeling maar geen sprake van onmiddellijkheid ${ }^{32}$. Het verhoor van een doofstomme verdachte ter terechtzitting door een rechter die evenals de verdachte gebarentaal beheerst kan onmiddellijk worden genoemd maar niet mondeling ${ }^{3}$. Zo geldt ook dat het verhoor waarbij de getuige met krijt het antwoord op een groot zwart hord schrijft, nadat de rechter dalarvoor zijn vraag daarop heeft neergeschreven, onmiddellijk is maar niet mondeling ${ }^{4}$. In deze voorbeelden zijn spraak en schrift slechts vormen van communicatie, die gelijkwaardig aan elkaar zijn als spontane uitdrukking van gedachten. De mening dat de schriftelijke verklaring in dit voorbeeld ten opzichte van de mondelinge verklaring een reproduktie van informatie zou behelzen acht Maas onjuist. Daarbij merkt hij wel op dat dit alleen geldt wanneer de schriftelijke procesvoering zich direkt voor het gerecht afspeelt $t^{35}$.

Wat hieruit kan worden afgeleid is dat volgens Maas de onmiddellijkheid vereist dat de rechter de verklarende persoon zelf ziet en hoort. Of de verklaring en het verhoor van die persoon nu in mondelinge of schriftelijke vorm geschiedt is daarbij volgens hem voor het onmiddellijkheidsbeginsel onbelangrijk. In de volgende paragraaf wordt duidelijk dat deze laatste bewering niet kan worden volgehouden.

31 S. Maas, Der Grundsatz der Unmiltclbarkcit in der Reichsstrafprozessordnung, Breslau 1907, p. 25 en 26.

32 S. Maas (1907), a.w., p. 4.

33 S. Maas (1907), a.w., p. 5.

34 S. Maas (1907), a.w., p. 8.

35 S. Maas (1907), a.w., p. 9. 
Tegenwoordig lijkt, aldus Geppert, in de Duitse literatuur over het wezen en de inhoud van het beginsel der mondelinge procesvoering toenemende overeenstemming te bestaan ${ }^{36}$. Het beginsel der mondeling procesvoering betreft alleen de vorm van communicatie waarvan alle procesdeelnemers zich bedienen ten overstaan van en met de rechter. Volgens het beginsel der mondelinge procesvoering mag alleen het mondeling op de terechtzitting voorgedragen bewijsmateriaal tegen de verdachte worden gebruikt. Dit betekent echter niet dat al het schriftelijke materiaal zijn waarde voor het bewijs verliest. Slechts dat materiaal mag voor het oordeel worden gebruikt, dat door het medium van het gesproken woord aan de rechter en de verdachte is geopenbaard. $\mathrm{Zo}$ is heel goed verenigbaar met het beginsel der mondelinge procesvoering dat processen-verbaal van verhoren uit het vooronderzoek voor het bewijs worden gebruikt, wanneer zij ter terechtzitting zijn voorgelezen. Of deze schriftelijke stukken voor het bewijs mogen worden gebruikt, kan aan de hand van het beginsel der mondelinge procesvoering niet worden beantwoord ${ }^{3}$.

Het heginsel van de mondelinge procesvoering is van belang voor de externe openbaarheid. Door de mondelinge procesvoering wordt het onderzoek ter terechtzitting transparant gemaakt". Hoewel externe openbaarheid in theorie ook denkbaar is ten aanzien van een schriftelijk proces - men kan kennisnemen van alle processtukken - draagt het beginsel van de mondelinge procesvoering ertoe bij dat het externe openbaarheidsbeginsel beter tot zijn recht komt. Het publiek kan door niddel van de eigen waarneming (publicke tribune) of door de media (pers) zich op de hoogte stellen, zich een oordeel vormen en aldus controle uitoefenen op het functioneren van de rechtspraak. Controle betekent dat de rechtspleging zich zo zichtbaar voltrekt dat de mogelijkheid bestaat er kennis van te nemen en er kritiek op te leveren ${ }^{*}$. De mondelinge procesvoering vormt hiertoe een wezenlijke bijdrage.

Voorts is het beginsel van de mondelinge procesvoering belangrijk voor het dialectisch proces van waarheidsvinding ${ }^{\text {at }}$. Door middel van spraak en tegenspraak, vraag en antwoord, instemming en bestrijding, argument en tegenargument biedt het gesproken woord als vorm van communicatie grotere garanties voor een waarheidsgetrouw en rechtvaardig oordeel dan kan worden bereikt via de schriftelijke vorm. Het is vooral Mittermaier die deze voordelen van de mondelinge procesvoering heeft benadrukt en die ook heeft gewezen op de procespsychologische kant van dit beginsel als middel tot een betere waarheidsvinding. Voor de juiste waardering van de verkla-

36 K. Geppert, Der Grundsatz der Unmittclbarkeit im deutschen Strafverfahren, Berlin 1979, p. 138.

37 K. Gicppert (1979), a.w., p. 139.

38 K. Geppert (1979), a.w., p. 139 en 140.

39 U. van de Pol, Openbaar terecht; Een onderzock van het openbaarheidsheginsel in de strafrechtspleging, Arnhem 1986, p. 583 cn 584.

40 K. Gepperl (1979), a.w., p. 140 en 141. 
ring is van belang dat de rechter kan letten op de toon, de wijze van uitdrukking, de aarzeling of juist vastberadenheid van de getuige bij het afleggen van zijn verklaring. \%o kan worden geconcludeerd dat, hoewel uit het beginsel der mondelinge procesvoering weliswaar geen onmiddellijkheid voortvloeit, het onmiddellijkheidsbeginsel daarentegen wel eist dat het proces mondeling wordt gevoerd.

\subsection{Conclusie}

Volgens Von Feuerbach is het beginsel van mondelinge procesvoering alleen van toepassing op de relatie tussen partijen en de rechter. De al dan niet direkte confrontatie tussen partijen en de oordelende rechter bepaalt of er sprake is van een mondelinge dan wel schriftelijke procesvoering. De al dan niet direkte confrontatie tussen getuigen en deskundigen enerzijds en het oordelende gerecht anderzijds is voor de vraag of er sprake is van een mondelinge dan wel schriftelijke procesvoering irrelevant. De direkte confrontatie tussen de aangeklaagde en getuigen/deskundigen betreft de inwendige openbaarheid van het proces.

Voor Mittermaier zijn de beginselen van mondelinge procesvoering en onmiddellijkheid identiek. Ilet beginsel der mondelinge procesvoering eist dat alle getuigen ten overstaan van de oordelende rechter en in aanwezigheid van de beschuldigde mondeling hun verklaringen afleggen.

Volgens Malas betreft het beginsel der mondelinge procesvoering alleen de vorm vals communicatie waarvan de procesdeelnemers zich ter terechtzitting moeten bedienen. Het onmiddellijkheidsheginsel daarentegen vereist de direkte confrontatie van alle procesdeelnemers en het bewijs. Of men zich bij die confrontatie bedient van de mondelinge dan wel schriftelijk vorm van communicatie is in de ogen van Maas voor het onmiddellijkheidsbeginsel onbelangrijk.

In de moderne Duitse literatuur ziet men het beginsel van mondelinge procesvoering als de keuze voor de mondelinge vorm van communicatie waarvan procesdeelnemers zich ten overstaan van en met de rechter moeten bedienen. Dit beginsel is van wezenlijk belang voor de externe openbaarheid. Het maakt de terechtzitting transaparant. Daarnaast is dit beginsel van belang voor het onmiddellijkheidsbeginsel omdat het gesproken woord als vorm van communicatie rijker is aan spontane expressie dan de schriftelijke vorm. Uit het beginsel der mondelinge procesvoering vloeit weliswaar geen onmiddellijkheid voor, het onmiddellijkheidsbeginsel daarentegen eist wel dat het proces mondeling gevoerd wordt.

\section{Opvattingen in de Duitse literatuur over de inhoud van het onmiddellijkheidsbe- ginsel}

In de Duitse literatuur is in tegenstelling tot de Nederlandse literatuur over de inhoud van het onmiddellijkheidsbeginsel als zelfstandig beginsel veel geschreven. Om tot 
een juiste begripsbepaling te komen is het daarom zinnig daarvan tot op zekere hoogte kennis te nemen. Ik beperk me hier tot de bespreking van een drietal monografiëen. Allereerst zal worden ingegaan op de opvatting van Maas over de inhoud van het onmiddellijkheidsbeginsel. Maas publiceerde zijn monografie over het onmiddellijkheidsbeginsel in 1907 en kan daarmee gezien worden als een van de eerste Duitse schrijvers die een poging doet het onmiddellijkheidsbeginsel als zelfstandig beginsel te definiëren. Vervolgens komen twee meer recente opvattingen uit de Duitse literatuur over de inhoud van het onmiddellijkheidsheginsel aan de orde. Allereerst is dat de opvatting van Löhr. gevolgd door de opvatting van Geppert.

\subsection{De opvatting van Maas over de inhoud van het onmiddellijkheidsheginsel}

Volgens Maas bestaat het onmiddellijkheidsheginsel uit twee bestanddelen: 'die Unmittelbarkeit der Tatsachenerschliessung' en 'die Unmittelbarkeit des Verkehrs'.

'Die Unmittelharkeit der Tatsachenerschliessung' vereist dat de rechter bij zijn onderzoek naar het strafbare feit in de meest direkte verhouding treedt tot de voorgevallen feiten ${ }^{4}$. Deze eis vloeit voort uit het inzicht dat de kans op vertekening van informatie groter wordt naarmate die informatie vaker wordt overgedragen. Elke overdracht van informatie omvat een subjectieve waardering en daarmee een kleuring van die informatie. Voor het oordeel dient dat bewijsmiddel gebruikt te worden dat zijn inhoud aan zichzelf ontleent. Zo verdient de verklaring van een getuige over wat hij zelf heeft waargenomen de voorkeur boven de getuigenverklaring van horen zeggen. Volgens Maas is dit bestanddeel van het onmiddellijkheidsbeginsel echter niet denkbaar zonder het andere bestanddeel: 'die Unmittelbarkeit des Verkehrs'.

'Die Unmittelbarkeit des Verkehrs' eist dat de rechter zowel de procespartijen als ook de persoonlijke en zakelijke bewijsmiddelen zelf direkt dient te zien en/of te horen ${ }^{42}$. Dit bestanddeel van het onmiddellijkheidsbeginsel is volgens Maas historisch bepaald: "Die Kenntnis der erkennenden Richters von strafrechtlich bedeutsamen Tatsachen sollte sich nicht gründen auf die Aufzeichnungen des Untersuchungsrichters oder das Referat des Referenten. ${ }^{49}$

Volgens Maas is duidelijk dat noch het ene noch het ander bestanddeel op zich zelf het onmiddellijkheidsbeginsel dekt. 'Die Unmittelbarkeit der Tatsachenerschliessung' sluit niet uit dat het meest originele bewijsmiddel indirekt via de stukken danwel mondelinge verklaring van de onderzoeksrechter of het schriftelijke danwel mondelinge referaat van de referent tot kennis van de rechter komt. 'Die Unmittelbarkeit des Verkehrs' vereist weliswaar dat het bewijsmiddel direkt tot kennis van de rechter

41 S. Maas (1907), a.w., p. 13.

$\$ 2$ S. Maas (1907), a.w., p. 14.

43 S. Maas (1907), a.w., p. 14. 
komt, maar sluit niet uit dat dit bewijsmiddel niet het meest direkte bewijsmiddel vormt dat voorhanden is ${ }^{4}$.

Om Maas goed te begrijpen is belangrijk te weten, dat in zijn visie de stukken danwel mondelinge verklaring van de onderzoeksrechter en het mondelinge danwel schriftelijke referaat van de referent als zodanig niet als bewijsmiddelen worden gezien. Dat blijkt bijvoorbeeld uit het volgende citaat: "Dass jedoch die Mittelbarkeit keineswegs das Dazwischentreten eines anderen Beweismittels erfordert, zeigt z.B. der von Beling erwähnte Fall, dass ein Gerichtsmitglied in der Hauptverhandlung über eine Zeugenvernehmung referiert. ${ }^{\text {14s }}$ Zou dat anders zijn, dan zou daarmee het onderscheid tussen de twee bestanddelen van het onmiddellijkheidsbeginsel vervagen. 'Die Unmittelbarkeit des Verkehrs' zou slechts een bijzonder geval zijn van 'die Unmittelbarkeit der Tatsachenerschliessung'. Immers, de stukken danwel mondelinge verklaringvan de onderzoeksrechter of het mondelinge danwel schriftelijke referaat van de referent zijn in feite niets meer dan een reproduktie van het oorspronkelijk bewijs. Het verbod om hiervan gebruik te maken zou dan al volgen uit de eis dat de rechter zich dient te bedienen van de meest originele bewijsmiddelen ('die Unmittelbarkeit der Tatsachenerschliessung').

\subsection{De opvatting van Löhr over de inhoud van het onmiddellijkheidsbeginsel}

Ook in de meer recente Duitse literatuur wordt vastgehouden aan de tweedeling in eisen die uit het onmiddellijkheidsbeginsel zouden voortvloeien.

Volgens Löhr gaat het bij het onmiddellijkheidsheginsel enerzijds om een 'Prinzip der Form', anderzijds om een 'Prinzip der Wahl'.

\subsubsection{Het onmiddellijkheidsbeginsel als 'Prinzip der Form'}

Als 'Prinzip der Form' eist het onmiddellijkheidsbeginsel dat er onmiddellijkheid bestaat in de relatie van de rechter tot de procesdeelnemers en de bewijsmiddelen. De rechter dient rechtstreeks (persoonlijk) kennis te nemen van al het bewijs in aanwezigheid van de procesdeelnemers ${ }^{\text {th }}$. Deze onmiddellijkheidseis beoogt, aldus Löhr, niet alleen de rechter (en nict de onderzoeksrechter of referent) als subject van bewijsvoering aan te wijzen en dus te bepalen voor wie en door wie de bewijsvoering dient te geschieden ${ }^{\text {s7 }}$. Deze eis geeft hovenal een antwoord op de vraag hoe de rechter dient kennis te nemen van de verklaring van de verdachte en van alle

44 S. Maas (1907), a.w., p. 14

45 S. Maas (1907), a.w., p. 7.

46 H.E. Löhr, Der Grundsatz der Unmiltclbarkeit im deutschen StrafprozeBrecht, Berlin 1972, p. 19 en 20.

47 H.E. Löhr (1972), a.w., p. 39. 
andere persoonlijke en zakelijke bewijsmiddelen, namelijk via eigen waarneming. Aan de vorm waarin de rechter kennis dient te nemen van de inhoud van de verschillende bewijsmiddelen komt zelfstandige betekenis toe ${ }^{48}$. De rechter mag zich bijvoorbeeld niet tevreden stellen met een door de getuige op schrift gestelde verklaring of telefonisch afgelegde verklaring. Weliswaar neemt de rechter ook dan direkt (persoonlijk) kennis van de verklaring van de getuige, maar deze vorm komt niet overeen met de eis van onmiddellijke waarneming van het bewijsmiddel: "Das Unmittclbarkeitserfordernis in diesem Sinne betrifft also die Frage der Benutzungsform eines Beweismittels. "Het gaat immers niet alleen om de inhoud van de verklaring, maar ook om de aard en wijze waarop deze wordt afgelegd, alsook om het totale gedrag van de verklarende persoon ${ }^{* 9}$. Op basis van zijn eigen waarneming kan de rechter een indruk krijgen van de persoonlijkheid van de verdachte, van de geloofwaardigheid der getuigen of de betrouwbaarheid van de deskundigen. Maar de betekenis van dit onmiddellijkheidsgebod ligt, volgens Löhr, niet alleen in de waarde van de persoonlijke indruk van de rechter. De aanwezigheid van de verdachte, de getuigen en de deskundigen ter zitting maken bovendien mogelijk dat onvolledige verklaringen door middel van vragen aangevuld worden, twijfel wordt opgeheven en tegenstrijdigheden worden weggenomen. De verdachte krijgt betere verdedigingsmogelijkheden. Het proces biedt daarmee de grootst mogelijke garantie tot waarheidsvinding ${ }^{50}$.

\subsubsection{Het onmiddellijkheidsbeginsel als 'Prinzip der Wahl'}

Als 'Prinzip der Wahl' eist het onmiddellijkheidsbeginsel de grootst mogelijke onmiddellijkheid in de verhouding tussen de rechter en de te bewijzen feiten. De rechter dient het meest onmiddellijke bewijs te gebruiken dat voorhanden is. Deze eis bepaalt zodoende welk van de voorhanden zijnde bewijsmiddelen de rechter aan zijn beslissing ten grondslag dient te leggen, namelijk het meest direkte bewijsmiddel ${ }^{51}$.

Deze eis komt voort uit het inzicht dat: "jede Vermittlung des Inhalts einer Beweisquelle eine Schwächung und Trübung der richterlichen Tatsachenerkenntnis bewirke. ${ }^{\prime 62}$

\subsubsection{Conclusie}

Volgens Löhr vloeien aldus uit het onmiddellijkheidsbeginsel twee inhoudelijk ongelijksoortige eisen" voort: "Während dic (..) Fordenıng nach unmittelharer Wahmemung

48 H.E. Löhr (1972), a.w., p. 39 en 40.

49 H.E. Löhr (1972), a.w., p. 41.

50 H.E. Lörh (1972), a.w., p. 41.

51 H.E. Löhr (1972), a.w., p. 20.

52 H.E. Löhr (1972), a.w., p. 47.

53 H.E. Löhr (1972), a.w., p. 20. 
der Beweismittel die Frage der besimöglichen Benutzungsform ein und desselben Beweismittels betrifft, handelt es sich hei der Fordening nach unmittelharer Beweisfülinung um die Frage der Wahl unter mehreren Beweismitteln, die für ein und dasselbe Beweisthema in Betracht kommen, also um die Frage des hestmöglichen Beweismittels. ${ }^{\text {th }} \mathrm{Nijboer}$ heeft er mijn inziens terecht op gewezen dat het door Löhr gemaakte onderscheid niet scherp is". De vraag hoe de rechter dient kennis te nemen van de verklaring van aan getuige - direkt en niet via de door de getuige op schrift gestelde verklaring dan wel de telefoon - omvat reeds de vraag welk van de voorhanden zijnde bewijsmiddelen - de schriftelijk opgestelde verklaring dan wel de op zitting afgelegde verklaring - de rechter aan zijn beslissing ten grondslag dient te leggen.

\subsection{De opvatting van Geppert over de inhoud van het onmiddellijkheidsheginsel}

Ook Geppert deelt het onmiddellijkheidsbeginsel in tweeën. Hij onderscheidt het formele en materiële onmiddellijkheidsheginsel. Beide dienen de waarheidsvinding ${ }^{\text {sh }}$.

\subsubsection{Het formele onmiddellijkheidsbeginsel}

Het formele onmiddellijkheidsheginsel eist dat alleen de door de rechter zelf waargenomen bewijsmiddelen de basis voor zijn oordeel vormen. De rechter is bewijsadressaat' en hieruit volgt dat in beginsel alleen het onderzoek ter terechtzitting als plaats van bewijsvoering in aanmerking komt. Alleen wat uit het onderzoek ter terechtzitting blijkt, mag als bewijs aan het oordeel ten grondslag worden gelegd. Op die manier eist het formele onmiddellijkheidsbeginsel niet meer dan dat de bewijsvoering geschiedt door de rechter ter terechizitting en dat het bewijs daar moet worden opgebouwd ${ }^{5}$. Het formele onmiddellijkheidsbeginsel verzet zich niet tegen het voorlezen en vervolgens gebruiken van processen-verbaal waarin getuigenverklaringen zijn opgenomen $^{\text {ss }}$. Aldus valt het formele onmiddellijkheidsbeginsel volgens Geppert samen met het beginsel der mondelinge procesvoering in die zin dat alleen dat wat ter terechtzitting mondeling werd geopenbaard voor het oordeel gebruikt mag worden". Het verschil tussen het formele onmiddellijkheidsbeginsel en het beginsel der mondelinge procesvoering ligt volgens deze schrijver in de omstandigheid dat het formele onmiddellijkheidsbeginsel enerzijds beperkter, anderzijds ruimer is dan 
het beginsel der mondelinge procesvoering. Het formele onmiddellijkheidsbeginsel is beperkter in die zin dat het alleen betrekking heeft op de bewijsvoering, waar het beginsel der mondelinge procesvoering zich uitstrekt tot het hele onderzoek ter terechtzitting ${ }^{\mathrm{t}}$. Het formele onmiddellijkheidsbeginsel is ruimer dan het beginsel der mondelinge procesvoering in die zin dat het bijvoorbeeld ook eisen stelt aan de waarnemingscapaciteiten van de zittingsrechter. Zo vormt een dove, blinde of slapende zittingsrechter een inbreuk op het formele onmiddellijkheidsbeginsel ${ }^{61}$. Het gaat om het aanschouwelijke dialectische discours dat in het kader van de waarheidsvinding zo belangrijk is. Waar het beginsel der mondelinge procesvoering meer formeel van aard is, dient het formele onmiddellijkheidsbeginsel meer materieel uitgelegd te worden. Niet alleen mag slechts dat wat zich ter zitting mondeling heeft geopenbaard voor het oordeel worden gebruikt, het formele onmiddellijkheidsbeginsel eist dat alles wat mogelijk op het oordeel van invloed is ter zitting ter discussie wordt gesteld. Daarmee omvat het formele onmiddellijkheidsbeginsel in de visie van Geppert ook de problematiek van het gebruik van eigen wetenschap door de rechter, de aanwezigheid van de verdachte ter zitting, de kennisneming door de rechter van de stukken uit het vooronderzoek en de invloed van de media op het proces en het oordeel $^{12}$.

\subsubsection{Het materiële onmiddellijkheidsbeginsel}

Het materiële onmiddellijkheidsheginsel eist dat de bewijsvoering geschiedt op basis van de meest onmiddellijke bewijsmiddelen ${ }^{\text {oi. }}$.'Onmiddellijk' is daarbij dat bewijsmiddel dat het te bewijzen feit in zekere zin uit eerste hand belicht en hatar bewijskracht ontleent aan zichzelf. 'Middellijk' daarentegen zijn die bewijsmiddelen, die hun bewijskracht van andere bewijzen afleiden, in die zin dat zij deze bewijzen slechts inhoudelijk reproduceren. Zo gezien eist het materiële onmiddellijkheidsbeginsel dat de rechter van de bewijsmiddelen zo mogelijk kennis neemt in hun originele $v^{v o r m}{ }^{4}$. Achter het materiële onmiddellijkheidsbeginsel gaat aldus de gedachte schuil van het best mogelijke bewijs".

\subsubsection{De controleerbaarheid van origineel bewijs}

De kwalificatie 'best mogelijke bewijs' ontleent het originele bewijs, aldus Geppert, aan zijn controleerbaarheid. De inhoud van een bewijsmiddel kan immers enkel

60 K. Geppert (1979), a.w., p. 141.

61 K. Geppert (1979), a.w., p. $147 \mathrm{l} / \mathrm{m} 150$.

62 K. Geppert (1979), a.w., p. $150 \mathrm{t} / \mathrm{m} 162$.

63 K. Geppert (1979), a.w., p. 163.

64 K. Geppert (1979), a.w., p. 166.

65 K. Geppert (1979), a.w., p. 166. 
dan basis voor het rechterlijk oordeel vormen, wanneer de rechter persoonlijk van de waarheidsgetrouwheid daarvan overtuigd is. De rechter dient daartoe niet alleen de inhoud van het bewijsmiddel maar ook de bewijskracht daarvan vast te (kunnen) stellen ${ }^{\text {. }}$. Bij het gebruik van originele bewijsmiddelen kan de rechter zelf de inhoud daarvan vaststellen om vervolgens de kwaliteit van hun bewijskracht te toetsen. Met betrekking tot de stukken van overtuiging levert dit laatste voor de rechter de minste problemen op. De rechter kan zich in het algemeen beperken tot de controle van de echtheid van een dergelijk bewijsmiddel. Met betrekking tot het deskundigenbewijs dient de rechter de deskundigheid van de desbetreffende persoon als ook zijn wetenschappelijke integriteit enzovoorts te onderzoeken. Eventuele hiaten of onduidelijkheden in zijn rapportage kan de deskundige door het beantwoorden van vragen aanvullen of ophelderen. De grootste problemen heeft de rechter bij de bewijskrachtcontrole van getuigenverklaringen of verklaringen van de verdachte zelf. De rechter dient de geloofwaardigheid van de desbetreffende persoon te toetsen en vast te stellen of deze persoon overeenkomstig de waarheid kan verklaren en ook bereid is dit te doen. Wanneer de getuige of verdachte zelf ter zitting verschijnt om daar zijn verklaring af te leggen dan biedt dit de rechter drie voordelen: Allereerst krijgt de rechter zo een persoonlijke indruk van de getuige of verdachte. Ten tweede heeft de rechter evenals alle andere procesdeelnemers de mogelijkheid op tegenstrijdigheden en onvolledigheden te wijzen en om nadere vragen te stellen. Ten slotte kunnen getuigen onderling of met de verdachte worden geconfronteerd, hetgeen van belang kan zijn voor een juiste waardering van de bewijskracht van de afzonderlijke verklaringen ${ }^{67}$.

\subsubsection{De controlecrbaarheid van gereproduceerd bewijs}

Wanneer originele bewijsmiddelen door afgeleide bewijsmiddelen worden vervangen, dan wordt het voor de rechter een stuk moeilijker dit bewijs op zijn juiste waarde te beoordelen. Daarbij wijst Geppert erop dat de belemmeringen voor een optimale bewijswaardering en daarmee de gevaren voor de waarheidsvinding variëren afhankelijk van de aard van het reproducerende bewijsmiddel enerzijds en het gereproduceerde originele bewijs anderzijds ${ }^{20}$.

\subsection{De reproduktie van 'persoonlijke bewijsmiddelen'}

Met betrekking tot de reproduktie van wat in Duitsland 'persoonlijke bewijsmiddelen' (verklaring van de getuige, de medeverdachte, de deskundige en de verdachte zelf) worden genoemd, kan worden geconstateerd dat er meerdere manieren van reproduktie bestaan: door middel van processen-verbaal van de politie of de onderzoeks-

66 K. Geppert (1979), a.w., p. 167.

67 K. Geppert (1979), a.w., p. 167 en 168.

68 K. Geppert (1979), a.w., p. 168. 
rechter, door schriftelijke optekening van de verklaring door de zegsman zelf, door bandopname en door mondelinge verklaring van een ander (de verklaring van horen zeggen).

a. Wat betreft de reproduktie van persoonlijke bewijsmiddelen door middel van een proces-verbaal, wijst Geppert op het probleem dat de rechter allereerst dient te controleren of de oorspronkelijke zegsman de voorgelezen verklaring wel heeft afgelegd. Een moeilijk te bantwoorden vraag daarbij blijft in hoeverre bijvoorbeeld de wijze van verhoor de verklaring heeft beïnvloed. In tegenstelling tot de situatie dat de oorspronkelijke zegsman zelf ter zitting verschijnt om daar zijn verklaring af te leggen, staat de inhoud van het bewijsmiddel bij de reproduktie door middel van een proces-verbaal niet bij voorbaat vast. De rechter dient zich bezig te houden met de kwaliteit van de reproduktie. Daar komt bij dat de beoordeling van de bewijskracht van het gereproduceerde bewijsmiddel problematisch is, omdat de op zijn geloofwaardigheid te beoordelen zegsman ter zitting niet aanwezig is. De rechter mist de drie eerdergenoemde voordelen van het originele bewijs: eigen indruk, het stellen van vragen en de confrontatie met andere getuigen of deskundigen en de verdediging ${ }^{*}$.

b. Voor de reproduktie van persoonlijke bewijsmiddelen door middel van de schriftelijke optekening van de verklaring door de oorspronkelijke zegsman zelf, geldt min of meer hetzelfde. De inhoud van de verklaring staat vast, maar de rechter dient zich wel van de echtheid van het schriftelijke stuk te vergewissen in die zin dat hij zeker moet zijn dat de geschreven verklaring afkomstig is van degene aan wie hij wordt toegeschreven. Verder ontbreekt ook hier het psychologische aspekt van het verhoor ter zitting. De rechter krijgt geen indruk van het gedrag van de desbetreffende persoon, er kunnen geen vragen worden gesteld en de confrontatie met andere procesdeelnemers is niet mogelijk $k^{\text {}}$.

c. Aangaande de reproduktie door middel van bandopnamen wijst Geppert erop dat deze voordelen biedt boven andere manieren van reproduktie, in zoverre dat de rechter een zekere indruk kan krijgen van de wijze waarop de verklaring wordt afgelegd. Toon, aarzeling, consistentie en dergelijke kunnen op band worden vastgelegd. Wel geldt ook hier dat de rechter zich dient te vergewissen van het feit dat de verklaring afkomstig is van degene aan wie hij wordt toegeschreven en of de bandopnames niet zijn vervalst. Verder mist de rechter ook hier de gelegenheid tot het stellen van vragen en kan de zegsman niet worden geconfronteerd met andere procesdeelnemers ${ }^{71}$.

d. Bij de reproduktie door middel van de mondelinge verklaring van een ander (de verklaring van horen zeggen) spelen onder andere de volgende problemen: Geeft de verklarende persoon het door hem gehoorde inhoudelijk correct weer?

69 K. Geppert (1979), a.w., p. 168 t/m 172.

70 K. Geppert (1979), a.w., p. 172 en 173.

71 K. Geppert (1979), a.w., p. $173 \mathrm{t} / \mathrm{m} 176$. 
Deze vraag betreft de betrouwbaarheid van het medium. Hier speelt het probleem van de subjectieve kleuring van informatie. Dit gevaar is groter wanneer iemand niet, zoals een opsporingsambtenaar of onderzoeksrechter, getraind is in het zo objectief mogelijk weergeven van informatie. Daar komen bij de beperkingen van het menselijk geheugen. Het menselijk geheugen wordt onder andere beinvloed door tijd en nieuwe informatie van buitenaf. Voordelig is wel dat de rechter ten aanzien van de verklarende persoon de drie eerder genoemde voordelen bezit: eigen indruk, het stellen van vragen en de confrontatie met de overige procesdeelnemers. Echter ten aanzien van de oorspronkelijke zegsman heeft de rechter deze voordelen niet. De beoordeling van de bewijskracht van het overgebrachte bewijs blijft daardoor problematisch ${ }^{\text {T2 }}$.

\subsection{De reproduktie van 'zakelijke bewijsmiddelen'}

Ook de bewijsmiddelen die in Duitsland 'zakelijke bewijsmiddelen' (stukken van overtuiging, ambtelijke stukken) worden genoemd, kunnen op verschillende manieren worden gereproduceerd. Zo kan bijvoorbeeld de beledigende brief in gekopieerde vorm ter kennis komen van de rechter. De opsporingsambtenaar die ter zitting een mondelinge omschrijving geeft van de plaats van het ongeval, reproduceert een zakelijk bewijsmiddel in mondelinge vorm. In het laatste geval zijn de problemen voor de rechter groter dan in het eerst genoemde voorbeeld. De kopie moet met het origineel overeenstemmen, maar ook dient de rechter na te gaan of het origineel zich in originele staat bevond op het moment dat de kopie werd gemaakt. Bij het laatste voorbeeld openbaren zich dezelfde problemen als genoemd bij de mondelinge reproduktic van persoonlijke bewijsmiddelen ${ }^{3}$.

\subsubsection{Conclusie}

In de opvatting van Geppert bestaat het onmiddellijkheidsbeginsel uit twee eisen. Het formele onmiddellijkheidsbeginsel eist dat alles wat mogelijk op het rechterlijk oordeel van invloed is ter terechtzitting ter discussie wordt gesteld. Het materiële onmiddellijkheidsbeginsel eist dat de bewijsvoering ter terechtzitting geschiedt aan de hand van de meest originele bewijsmiddelen, omdat met het oog op de controleerbaarheid het gebruik van origineel bewijs voor de bewijsvoering valt te prefereren boven gereproduceerd bewijs. Het materiële onmiddellijkheidsheginsel verzet zich in beginsel tegen elke reproduktie van bewijs ${ }^{\text {7s }}$.

72 K. Gcppert (1979), a.w., p. 176 t/m 179.

73 K. Geppert (1979), a.w., p. 179 en 180.

74 K. Geppert (1979), a.w., p. 181. 
Geppert wijst erop dat er in Duitsland over de precieze inhoud van het onmiddellijkheidsbeginsel nog steeds geen eenstemmigheid bestaat ${ }^{75}$. Duidelijk is geworden dat ook de opvattingen van Löhr en Geppert over de inhoud van het onmiddellijkheidsbeginsel uiteenlopen. Aspecten die Löhr rekent tot het onmiddellijkheidsbeginsel als 'Prinzip der Form' (denk aan het voorbeeld van de getuigenverklaring via de telefoon), rekent Geppert tot het materiële onmiddellijkheidsbeginsel (denk aan het voorbeeld van de reproduktie van persoonlijke bewijsmiddelen door middel van een bandopname). Daarnaast kan worden geconstateerd dat ook Geppert zijn onderscheid tussen het formele en materiële onmiddellijkheidsbeginsel niet consequent lijkt vol te houden. Waar hij enerzijds de aanwezigheid van de verdachte ter terechtzitting ziet als behorend tot het formele onmiddellijkheidsbeginsel, speelt anderzijds de confrontatie van het bewijs met de verdediging (en daarmee de aanwezigheid van de verdachte) ter zitting in het bijzijn van de rechter een rol bij de controleerbaarheid van het bewijs, maar wordt nu gezien als een uitvloeisel van het materiële onmiddellijkheidsbeginsel.

Toch kunnen ondanks de meningsverschillen en onduidelijkheden uit beide opvattingen van de inhoud van het onmiddellijkheidsbeginsel de aspecten worden gedistilleerd, waar het bij het onmiddellijkheidsbeginsel blijkbaar om draait.

Historisch bepaald en ook terug te vinden in de weergegeven omschrijvingen is dat het onmiddellijkheidsheginsel de rechter ter terechtzitting aanwijst als subject van bewijsvoering, omdat aan hem het oordeel in de strafzaak is opgedragen. Verder verzet het onmiddellijkheidsbeginsel zich in principe tegen elke reproduktie van bewijs. De rechter dient, indien zo mogelijk, voor zijn oordeel gebruik te maken van onmiddellijk bewijs. Omdat voor het oordeel van de rechter uiteindelijk zijn overtuiging van de waarheidsgetrouwheid van de verschillende bewijsmiddelen beslissend is, gaat het immers uiteindelijk om de bewijskracht die de rechter daaraan toekent. Om te weten welke bewijskracht de rechter aan de bewijsmiddelen moet toekennen, dient hij de bewijsmiddelen op hun betrouwbaarheid te kunnen controleren. Daartoe is noodzakelijk dat de rechter de oorspronkelijke bron van het bewijs zelf ziet en/of hoort. Het gaat immers niet om het reproducerende bewijs maar om het gereproduceerde bewijs. Of concreet uitgedrukt: Het gaat immers niet om het proces-verbaal maar om de daarin opgenomen verklaring van een getuige. Deze schriftelijk overgebrachte verklaring vormt de basis voor het uiteindelijke oordeel van de rechter. Alleen wanneer de rechter de oorspronkelijke getuige zelf ziet en hoort kan hij zich door middel van het stellen van vragen en door observatie een indruk vormen over de betrouwbaarheid van die getuige en zijn verklaring. Maar voor de controle van de betrouwbaarheid van het bewijs is naast de persoonlijke indruk noodzakelijk dat de rechter getuige is van de confrontatie tussen het originele 
bewijsmiddel, andere bewijsmiddelen en de verdediging. De verdediging beschikt vaak over informatie die de rechter mist. Voor het achterhalen van de ware toedracht vin het strafrechtelijk gebeuren is van belang dat met name de persoonlijke bewijsmiddelen ter terechtzitting onder leiding van de rechter op elkaar kunnen reageren. Het onmiddellijkheidsbeginsel eist van de rechter dat hij zich bij zijn onderzoek ter terechtzitting naar de voorgevallen feiten zo mogelijk bedient van onmiddellijke bewijsmiddelen omdat alleen dan aan het dialectisch proces van waarheidsvinding ter zitting vorm en inhoud kan worden gegeven.

\section{Opvattingen in de Nederlandse literatuur over de inhoud van het onmiddellijk- heidsbeginsel}

In de Nederlandse strafvorderlijke literatuur heeft het onmiddellijkheidsbeginsel zich nooit mogen verheugen in een grote belangstelling. Sinds een jaar of vijf lijkt hierin verandering te komen. Hierna volgt een bloemlezing over de opvattingen van het onmiddellijkheidsbeginsel die er zoal in de Nederlandse literatuur te vinden zijn. Daarbij valt op dat over de inhoud van het onmiddellijkheidsheginsel hier te lande niet zo diepgaand is nagedacht als in Duitsland. Er zijn maar weinig schrijvers die aan dit beginsel een fundamentele beschouwing wijden. Veel schrijvers lijken de inhoud en de ratio van het onmiddellijkheidsheginsel als bekend te veronderstellen. Dat dat niet zo is, blijkt al uit de vele verschillen in de opvattingen die hier worden besproken.

\subsection{De beschouwing van Simons over het onmiddellijkheidsbeginsel}

De oudste Nederlandse bron die ik heb kunnen vinden waarin over het onmiddellijkheidsbeginsel als zodanig wordt geschreven, stamt uit 1925. In zijn 'Beknopte handleiding tot het Wetboek van Strafvordering' schrijft Simons onder het kopje 'Mondelinge behandeling en het beginsel van de onmiddellijkheid": "Voor een goede rechtspraak is een eerste vereischte, dat de rechter alleen oordeelt op grond van bewijsmateriaal, dat voor hemzelf is bijgehracht, op grond van te zijnen overstaan afgelegde mondelinge verklaringen. Bij het eindonderzoek waren die beginselen ook in het strafproces van 1838 uitdrukkelijk erkend; daarentegen werden in het vooronderzoek alle rechterlijke beschikkingen betreffende de preventieve hechtenis genomen op grond van de schriftelijke stukken, de in de politie-verbalen of de processen-verbaal van den rechter-commissaris opgenomen verklaringen van de getuigen en van den beklaagde. ${ }^{106}$

Simons is van mening dat ook in het nieuwe wetboek (1926) bij het eindonderzoek de beginselen van mondelinge behandeling en van de onmiddellijkheid uitdrukkelijk

76 D. Simons, Beknopte handleiding tot het Wotbock van Strafvordering, Haarlem 1925, 7e druk, p. 31 en 32. 
zijn erkend: "Bij de omschrijving van de bewijsmiddelen in de artt. 340-343 wordt met eene enkele afwijking, art. 341 lid 2, steeds uitdrukkelijk vermeld dat de verklaring moet zijn geschied "bij het onderzoek ter terechtzitting". De door de rechtbank te geven beslissing moet naar art. 348 gegeven worden "naar aanleiding van het onderzoek op de terechtzitting. ${ }^{\prime m}$

Uit de aangehaalde citaten lijkt voort te vloeien dat Simons van mening is dat het onmiddellijkheidsbeginsel eist dat de rechter zelf de bewijsmiddelen ter terechtzitting dient te zien en of te horen. De rechter mag zijn oordeel niet baseren op het proces-verbaal van de politie of de rechter-commissaris. Simons lijkt met name het oog te hebben op de schriftelijke reproduktie van bewijs door deze justitiële ambtenaren. De getuigen en de verdachte dienen ter zitting te verschijnen om daar hun verklaringen mondeling af te leggen. De rechter dient te beslissen naar aanleiding van het onderzoek ter terechtzitting. Het probleem van de ter zitting afgelegde getuigenverklaring van horen zeggen laat Simons verder buiten beschouwing. Wel ziet Simons het gebruik voor het bewijs van processen-verbaal ex art. 344 lid 1 sub 2 Sv, zonder dat degene die het verbaal heeft opgemaakt mondeling behoeft te worden gehoord, als een uitzondering op de beginselen van de mondelinge behandeling en het onmiddellijkheidsbeginsel ${ }^{*}$. Het betreft hier de reproduktie van bewijs door middel van de schriftelijke optekening van de verklaring door de oorspronklijke zegsman zelf. Of het hier gaat om een uitzondering van het beginsel der mondelinge behandeling dan wel het onmiddellijkheidsbeginsel en waarom, maakt Simons niet duidelijk, evenmin als de relatie tussen beide beginselen en hun ratio.

\subsection{De opvatting van Stolwijk over het onmiddellijkheidsbeginsel}

Volgens Stolwijk eist het onmiddellijkheidsbeginsel dat de rechter ter terechtzitting de zaak onderzoekt aan de hand van de meest direkte bronnen van informatie die voor handen zijn. De rechter moet beraadslagen en vonnis wijzen op basis van de persoonlijke indrukken die hij tijdens de zitting opdoet. "Op deze wijze wordt bevorderd dat de resultaten van het onderzoek voldoen aan de hoogst mogelijke maatstaven van betrouwbaarheid en zongvuldigheid. Waarom dat zo is, maakt Stolwijk niet duidelijk. Wel stelt Stolwijk consequent vast dat het onmiddellijkheidsbeginsel een rol speelt bij het leerstuk in het bewijsrecht van het zogenaamde 'testimonium de auditu'. Dit leerstuk houdt het verbod in om verklaringen van getuigen uit tweede hand (van horen zeggen) als rechtsgeldige getuigenverklaringen aan te merken ${ }^{*}$. Wat opvalt, is dat deze auteur aspecten van het onderzoek ter terechtzitting, die door Geppert in verband werden gebracht met het onmiddellijkheidsbeginsel, los daarvan behandelt.

79 S.A.M. Stolwijk, Het onderzoek ter terechtzitting in strafyaken, Arnhem 1976, p. 6.

80 S.A.M. Stolwijk (1976), a.w., p. 6. 
Ter herinnering zij hier herhaald dat volgens Geppert het formele onmiddellijkheidbeginsel niet enkel eist dat alleen dat wat zich ter terechtzitting mondeling heeft geopenbaard voor het oordeel mag worden gebruikt, maar ook dat alles wat van invloed is op het rechterlijk oordeel ter zitting ter discussie wordt gesteld. Stolwijk stelt over het aanvaarden van het onderzoek ter terechtzitting als enige informatiebron van de rechter, dat dit in de eerste plaats tot doel heeft te verzekeren dat geen uitspraak wordt gedaan alvorens de rechter zich zelfstandig op grond van hem in het onderzoek geopenbaard materiaal een oordeel heeft gevormd. Hieruit vloeit voort dat de betrokken rechter het gehele onderzoek moet hebben bijgewoond om aan de uitspraak te mogen meewerken. In de tweede plaats dient de regel tot waarborg voor de verdediging en de officier van justitie dat de rechter uit geen andere informatiebronnen put dan die worden aangeboord in het onderzoek waaraan zij kunnen deelnemen en op het verloop waarvan zij invloed kunnen uitoefenen. Aldus zijn zij verzekerd dat elk naar hun mening voor de uitspraak relevant aspect van het onderzoek onder ogen van de rechter komt en zo nodig van meer zijden wordt belicht ${ }^{21}$. In dit kader wijst Stolwijk ook op het probleem van de eigen professionele en niet-professionele kennis en ervaring van de rechter, die in het denk- en waarderingsproces een beslissende rol kunnen spelen en de zogenaamde feiten van algemene bekendheid ${ }^{22}$. In het kader van de van de rechter te eisen onbevangenheid wijst Stolwijk ook op de omstandigheid dat de rechter vooraf aan de terechtzitting kennis neemt van alle procestukken ${ }^{k i}$. Een relatie met het onmiddellijkheidsbeginsel legt hij hier niet.

\subsection{Strekking en belang van het onmiddellijkheidsbeginsel volgens F.F. Langemeijer}

F.F. Langemeijer is van mening dat het onmiddellijkheidsbeginsel uitdrukkelijk is neergelegd in art. $338 \mathrm{~Sv}$, dat bepaalt dat de rechter het bewijs dat de verdachte het telastegelegde feit heeft begaan, alleen kan aannemen, indien hij daarvan uit het onderzoek ter terechtzitting door de inhoud van wettige bewijsmiddelen de overtuiging heeft bekomen. "Het beginsel krijgt vooral belang wanneer men als bewijsmiddel gegevens en verklaringen wil gebruiken welke anders dan terterechtzitting zijn gebleken; met name kan zich zulks voordoen wanneer in het gerechtelijk vooronderzoek verklaringen zijn afgelegd", aldus deze auteur. De wetgever heeft willen voorkomen dat de rechter ter terechtzitting al te zeer beïnvloed zou worden door hetgeen in het vooronderzoek heeft plaatsgevonden ${ }^{4}$. De strekking van dit beginsel hangt volgens F.F. Langemeijer samen met die van het accusatoire proces waarin partijen ter zitting hun bewijsmiddelen aandragen en de rechter slechts op grond van deze middelen mag beslissen. Partijen, met name de verdachte en zijn raadsman, moeten de volledige gelegenheid

81 S.A.M. Stolwijk (1976), a.w., p. 4.

82 S.A.M. Stolwijk (1976), a.w., p. 5.

83 S.A.M. Stolwijk (1976), a.w., p. 11.

84 F.F. Langemeijer, Het onmiddellijkheidsbeginsel in het militaire strafproces, D\&D 1976, p. 97. 
hebben om ieder hun partijstandpunt te verdedigen. Dit is alleen mogelijk als zij kennis kunnen nemen van alle gegevens waarop de rechter zijn beslissingen grondts. Bovendien lijkt hij het onmiddellijkheidsbeginsel niet alleen van belang te achten voor de interne maar ook de externe openbaarheid: "De openbaarheid van het onderzoek op de terechtzitting is een té grote waarborg dan dat men deze lichtvaardig mag voorbijgaan." Dalarnaast bekommert hij zich ook om de positie van de rechter die "thans zijn oordecl geheel moet haseren op informatie uit tweede hand."

Het probleem bij Langemeijer is, net als bij veel andere Nederlandse auteurs, dat hij zijn beschouwing niet uitwerkt. Daardoor blijft de betekenis van het onmiddellijkheidsbeginsel onduidelijk.

\subsection{Inhoud van het onmiddellijkheidsbeginsel volgens Nijboer}

Op het voorgaande aansluitend kan worden gezegd dat Nijboer terecht vaststelt dat in de strafprocesrechtelijke literatuur over het onderzoek ter terechtzitting met een zekere vanzelfsprekendheid nogal eens wordt verwezen naar het onmiddellijkheidsheginsel, zonder dat over de inhoud da:irvan consensus blijkt te bestaan ${ }^{* 7}$. In een poging over de inhoud van het onmiddellijkheidsbeginsel duidelijkheid te verschaffen stelt hij vast dat er in de Nederlandse literatuur globaal genomen twee opvattingen over de inhoud van het onmiddellijkheidsbeginsel hestaan.

In de eerste (formele) opvatting gait het orn de vorm van de procesvoering tijdens het onderzoek ter terechtzitting. Het onmiddellijkheidsheginsel duidt op het idee van rechtsstreeks contact, die in deze opvatting wordt toegepast op a) de relatie tussen de rechter en de procespartijen en b) de relatie tussen rechter en procespartijen enerzijds en derden-informanten, zoals getuigen en deskundigen anderzijds. In deze visie omvat het onmiddellijkheidsbeginsel volgens Nijboer soms mede de eis van mondelinge overdacht van informatie, alswel de eis dat de verdachte in staat moet zijn het gehele onderzoek ter terechtzitting bij te wonen ${ }^{s s}$.

In de tweede (materiële) opvatting houdt het onmiddellijkheidsheginsel de eis in dat gestreefd moet worden naar het gebruik van de meest directe (authentieke) bron van informatie. De ratio daarvan ligt in de overweging dat de kans op vertekening van informatie - vooral waar het gaat om wat iemand heeft waargenomen bij overdracht van die informatie door tussenpersonen groter is dan wanneer de betrokken informant die informatie zelf verschaft ${ }^{\text {sक }}$.

85 F.F. Langemeijer (1976), a.w., p. 97 en 98.

86 F.F. Langemeijer (1976), a.w., p. 100.

87 J.F. Nijhoer, Enkele opmerkingen over de betckenis van het onmiddellijkheidsbeginscl in het strafprocesrecht, NJB 1979, p. 821.

88 J.F. Nijboer (1979), a.w., p. 822.

89 J.F. Nijboer (1979), a.w., p. 822 en 823. 
Nijboer is van mening dat alleen aan het onmiddellijkheidsheginsel in de materiële opvatting zelfstandige betekenis toekomt, omdat de verschillende elementen die in de formele opvatting worden genoemd vanuit andersoortige beginselen verklaard kunnen worden ${ }^{\circ}$. Bij het rechtstreekse contact van de rechter met de procespartijen gaat het volgens Nijhoer om de (mogelijke) aanwezigheid van die partijen bij het onderzoek, als om de mogelijkheden die zij hebben om invloed uit te oefenen op de loop van het onderzoek. De aanwezigheid van de verdachte (en diens raadsman) en het openbaar ministerie bij het onderzoek ter terechtzitting staat ten dienste van hun recht om kennis te verkrijgen van alle voor de (eind)beslissing te gebruiken gegevens en hun bevoegdheid invloed uit te oefenen op de loop van het onderzoek teneinde hun specifieke belangen te behartigen. Zij zijn in de gelegenheid om wat zij van belang achten voor de rechterlijke oordeelsvorming naar voren te (doen) brengen. Bovendien kunnen zij kritiek leveren op informatie die van andere zijde wordt ingebracht. Deze in het proces geschapen mogelijkheden berusten volgens Nijhoer - in het bijzonder wat de verdachte aangaat - vooral op argumenten van behoorlijkheid. Zij kunnen echter heel goed vanuit andersoortige beginselen worden verklaard. Zo vormt de (mogelijke) aanwezigheid van de procespartijen ter terechtzitting een uitwerking van het beginsel van de interne openbaarheid en kan de mogelijkheid om invloed uit te oefenen op het onderznek worden aangeduid als een uitvloeisel van het beginsel van de contradictoire behandeling. De eis van de mondelinge procesvoering hangt volgens Nijboer samen met de externe openbaarheid van het proces in de fase van het onderzoek ter terechtzitting en met de concentratie van het onderzock ${ }^{j 1}$. Nijhoer pleit er dan ook voor om de aanduiding onmiddellijkheidsbeginsel bij voorkeur uitsluitend te bezigen voor de eis dat gestreefd moet worden naar het gebruik van de meest authentieke bron van informatie ${ }^{32}$.

Wat aan Nijboer kan worden tegengeworpen is dat het onmiddellijkheidsbeginsel is ontstaan uit het streven de rechter ten behoeve van de waarheidsvinding een betere oordeelsbasis te verschaffen ${ }^{93}$. De elementen die in de formele opvatting van het onmiddellijkheidsbeginsel worden genoemd moeten daarom tegen die achtergrond worden uitgelegd. De gedachte is dat de aanwezigheid van procespartijen ter terecht-

90 Zo ook P. Traest, Het bewijs in strafzaken, Gent 1992 , p. $278 \mathrm{t} / \mathrm{m} 281$.

91 J.F. Nijboer (1979), a.w., p. 823 en 824. In dit verband is averigens interessant dat Nijboer van mening is dat de eis tot mondelinge informatic-overdracht (ook) niet zonder meer voortvloeit uit het materiecl opgevatte onmiddellijkheidsbeginsel: "Als men een door dc oorspronkelijke informant opgeschreven relaas kan gebruiken (dat ook ter inzage aan de procespartijen verstrekt kan worden) is dat niet een minder direkte wijze van overbrengen dan een mondeling relaas." Ik roep in herinnering dat Geppert het opschrijven van een verklaring door de oorspronkelijke zegsman beschouwt als een vorm van reproduktic. Duidelijk is dat Nijboer de psychologische aspecten van de mondelinge procesvoering buiten beschouwing laat.

92 J.F. Nijboer (1979), a.w., p. 824. Zie ook J.F. Nijboer, Algemene grondslagen van de bewijsbeslissing in het Nederlandse strafprocesrecht, Arnhem 1982, p. $21 \mathrm{t} / \mathrm{m}$ 27, waarin hij dezelfde opvalting weergeeft en toelicht. 
zitting, de hen geboden mogelijkheid om op het onderzoek invloed uit te oefenen en de mondelinge procesvoering bijdragen aan een betere waarheidsvinding. Deze elementen berusten in het kader van het onmiddellijkheidsbeginsel daarom niet hoofdzakelijk op argumenten van behoorlijkheid maar vooral op argumenten van deugdelijkheid. Het gaat erom dat de rechter de procespartijen kan zien, hun gedrag en voorkomen kan observeren. Van belang is immers ook de wijze waarop procespartijen invloed uitoefenen op het onderzoek, waaraan de mondelinge procesvoering een belangrijke bijdrage levert. Kortom, het draait om het voor de rechter aanschouwelijke dialectisch proces van waarheidsvinding.

\subsection{Belang van het onmiddellijkheidsbeginsel volgens Reijntjes}

Reijntjes is evenals F.F. Langemeijer van mening dat het onmiddellijkheidsheginsel ten grondslag ligt aan art. $338 \mathrm{~Sv}$. Aan de eigen waarneming van de rechter en de verklaringen van de verdachte, getuigen en deskundigen mag alleen waarde worden gehecht, indien die waarneming/die verklaringen tijdens het onderzoek ter terechtzitting is gedaan/zijn afgelegd. Volgens Reijntjes is dit heginsel vermoedelijk ontsproten aan de wens, dat de verdachte ten behoeve van zijn verdediging rechtstreeks ter zitting hoort wat tegen hem wordt aangevoerd ${ }^{\text {s4 }}$. Uit het vorige hoofdstuk blijkt dat het onmiddellijkheidsbeginsel is voortgekomen uit het streven de rechter een betere basis te bieden voor zijn oordeelsvorming, waarvoor één van de voorwaarden is dat de verdachte ten behoeve van zijn verdediging rechtstreeks ter zitting hoort wat tegen hem wordt aangevoerd.

Het onmiddellijkheidsbeginsel draagt volgens Reijntjes ertoe bij dat de controle op de rechter wordt bevorderd.

Maar het grootste belang ontleent dit beginsel volgens deze auteur aan haar waarde voor de elementen explicatie en demonstratie, die volgens hem in het moderne strafproces zo'n grote rol spelen, althans zouden moeten spelen ${ }^{\circ 5}$. Deze elementen komen voort uit het inzicht dat berechting ter terechtzitting door haar demonstratief karakter een sanctie op zichzelf is en bovendien onafhankelijk van een eventuele strafoplegging explicatie biedt over wat 'men' veroordeelt of (naar de wil van de wetgever, vertolkt door de rechter en het openbaar ministerie) zou moeten veroordelen. De berechting verduidelijkt het geldingsbereik van de (beweerdelijk) overtreden regel en demonstreert het vaste voornemen van de overheid om die regel te handhaven. Het effect is niet alleen rechtshandhavend maar ook rechtsvormend. Bovendien kan en moet het proces een rol spelen bij de conflictoplossing, onder meer door duidelijk te maken, zo goed als aan de verdachte zelf als aan alle andere betrokkenen, hoe de gewraakte gebeurtenissen zich precies hebben afgespeeld. Tijdens het proces

94 J.M. Reijntjes, Strafrechtelijk hewijs in wet en praktijk. Arnhem 1980, p. 44.

95 J.M. Reijntjes (1980), a.w., p. 44. 
moet worden gepoogd, een stuk historie over het voetlicht te krijgen, niet louter om vast te stellen of de verdachte strafwaardig is, maar ook ter explicatie (en mogelijke rechtvaardiging) van het gedrag van de verdachte en de daarop gevolgde of nog te volgen reactie ${ }^{\%}$.

Duidelijk is dat Reijntjes de betekenis van het onmiddellijkheidsbeginsel vooral ziet in het belang van de openbaarheid. Controle op de rechter, rechtshandhaving, rechtsvorming, conflictoplossing en legitimatie, allemaal doelen van externe openbaarheid die, zoals Mittermaier al signaleerde, beter bereikt worden naar mate het proces meer beantwoordt aan het onmiddellijkheidsbeginsel. Belangrijk is dat Reijntjes ook het belang van het onmiddellijkheidsbeginsel signaleert voor wat ik gemakshalve maar even noem de 'interne' legitimatie van het onderzoek ter terechtzitting. Het onderzoek ter terechtzitting dient ook ter explicatie en rechtvaardiging van de nog te volgen reactie jegens de verdachte. Hier wordt herhaald hetgeen Mittermaier daarover schreef: "Daß das Gefühl der Beruhigung erzeugt wird, wenn er sicher ist, daß er selbst vor seinen Richtern seine ganze Denk-und Vorstellungsweise und die daran geknüpfte Vertheidigung vortragen konnte, daß er Alles, was er gegen die frühere Untersuchung einwenden, vortragen durfte, und auf die Erhebung der Beweise selbst wirken konnte. $^{\text {w7 }}$

\subsection{De opvatting van Mols over het onmiddellijkheidsbeginsel}

De laatste Nederlandse auteur die in deze bloemlezing van opvattingen over het onmiddellijkheidsbeginsel aandacht verdient, is Mols. In 1989 wijdde hij zijn oratie aan het onmiddellijkheidsbeginsel. Naar zijn mening eist het onmiddellijkheidsbeginsel dat het eindonderzoek in het openbaar en mondeling wordt gevoerd voor een onafhankelijke rechter die geroepen is een beslissing te nemen, bij voorkeur op basis van het beste bewijsmateriaal dat voorhanden is ${ }^{98}$. Hij onderscheidt aan dit beginsel drie aspecten met verschillend perspectief.

a. Het eerste aspect betreft de positie van de verdachte. Door de presentatie ter zitting in aanwezigheid van de verdachte van aanklacht en bewijsmateriaal, wordt deze in de gelegenheid gesteld zijn verdediging onmiddellijk en gedetailleerd te voeren. Hij kan ter zitting tegen de beschuldiging en het aangebrachte bewijsmateriaal alles aanvoeren wat volgens hem tot verdediging strekt $t^{\infty}$.

b. Het tweede aspect betreft de rechterlijke functie. De zittingsrechter is geroepen om over de schuldvraag een zelfstandig cordeel te geven in volstrekte onafhanke-

J.M. Reijntjes (1980), a.w., p. 5.

97 C.J.A. Mittermaier (1845), a.w., p. 260.

98 G.P.M.F. Mols, Staande de zitting; een heschouwing over het onmiddellijkheidsbeginscl, Arnhem 1989 , p. 6 en 7. 
lijkheid. Dit impliceert dat ter zitting alle getuigen worden gehoord en gezien door de rechter zodat hij daadwerkelijk een zelfstandig oordeel kan geven over de kwaliteit en de mate van betrouwbaarheid van het getuigenbewijs. Meest wezenlijk, noemt Mols het, dat door de verschijning van de getuigen ter zitting het dialectisch proces van waarheidsvinding vorm en inhoud wordt gegeven. De procespartijen en de rechter zijn in de gelegenheid om vragen te stellen en getuigen te confronteren met andere informatie en/of tegenstrijdigheden in hun verklaring op zoek naar de waarheid. ${ }^{100}$

c. Het derde aspect dat hij onderscheidt betreft de openbaarheid. De openbaarheid is een eerste vereiste om democratische controle, rechtsgelijkheid en uiteindelijk om de idealen van onze strafrechtspleging mogelijk te maken, aldus Mols. Dit impliceert volgens hem de volle presentatie ter zitting van alle argumenten en kwaliteiten in geding, of preciezer, de beste argumenten en kwaliteiten die partijen voorhanden hebben ${ }^{101}$.

De kern van het onmiddellijkheidsbeginsel is volgens Mols gelegen in de presentatie ter zitting van alles wat voor de juridische en daarmee politiek-rechtsstatelijke beoordeling van de zaak van belang is. De confrontatie van de procespartijen en de rechter met de beschuldiging en met het bewijsmateriaal noemt hij essentieel. Voor een scherper begrip van de juiste inrichting van het eindonderzoek spreekt hij daarom liever van het confrontatiebeginsel: "Een eindonderzoek dat niet of in onvoldoende mate aan dit beginsel tegemoet komt, doet in dezelfde mate afbreuk aan alle drie hienoor genoemde aspecten: het accusatoire karakter, de autonome rechterlijke functie, en de openbaarheid van de strafrechtspleging. ${ }^{1702}$

Nieuw, in zoverre dat andere auteurs daaraan in het kader van het onmiddellijkheidsbeginsel nog geen aandacht besteedden, is dat Mols aan de autonome rechterlijke functie nog een ander aspect verbindt dan de eindverantwoordelijkheid voor de waarheidsvinding. Dit andere aspect betreft de rechterlijke controle op het optreden van politie en justitie. Mols wijst erop dat in een rechtsstaat het uitgangspunt dat de executieve gecontroleerd wordt door de onafhankelijke rechter onwrikbaar verankerd dient te zijn ${ }^{103}$. Ook dit uitgangspunt komt onder zwaardere druk te staan naar mate het onmiddellijkheidsbeginsel wordt gerelativeerd.

\section{Begripsbepaling van het onmiddellijkheidsbeginsel}

Dan is nu het moment aangebroken om op bassis van de voorafgaande uit de literatuur afgeleide informatie te komen tot een eigen definitie van het onmiddellijkbeginsel.

100 G.P.M.F. Mols (1989), a.w., p. 7.

101 G.P.M.F. Mols (1989), a.w., p. 8.

102 G.P.M.F. Mols (1989), a.w., p. 8.

103 G.P.M.F. Mols (1989), a.w., p. 32. Zie ook bijwoorbeeld p. 12 en 13. 
Uit de bespreking van de opvattingen over het onmiddellijkheidsbeginsel uit de Duitse en Nederlandse literatuur blijkt dat men het ondanks de vele meningsverschillen over één ding eens is: het onmiddellijkheidsbeginsel verzet zich tegen het gebruik door de rechter van gereproduceerd bewijs voor zijn oordeel. De ratio van dit verzet moet, zoals Geppert mijns inziens terecht vaststelt, worden gezocht in de moeilijkheden die de rechter heeft om gereproduceerd bewijs op zijn betrouwbaarheid en kwaliteit te controleren. Bij de controle van gereproduceerd bewijs mist de rechter de drie voordelen die hij heeft bij de controle van origineel bewijs. Deze drie voordelen zijn:

a. de rechter krijgt een eigen indruk van de bewijsmiddelen (het stuk van overtuiging, dan wel de verklarende persoon);

b. de rechter kan, wanneer het gaat om de verklaring van een persoon, de zegsman nadere vragen stellen omtrent onduidelijkheden en/of tegenstrijdigheden;

c. de rechter kan de zegsman confronteren met ander bewijs en hetgeen de verdachte ter verdediging aandraagt.

Deze drie voordelen zijn niet los van elkaar te zien, maar hangen met elkaar samen. $\mathrm{Zij}$ volgen elkaar niet op in tijd, maar werken gelijktijdig en continu, gedurende het bewijsonderzoek ter terechtzitting. $\mathrm{Zij}$ maken deel uit van het dialectisch proces van waarheidsvinding. Alvorens tot een eigen definitie van het onmiddellijkheidsbeginsel te komen, verdienen deze drie voordelen echter nog enige toelichting.

\subsection{Eigen indruk van de rechter}

Bewijs bestaat altijd uit bepaalde informatie met een zekere relevantie voor de aan de verdachte verweten gedraging. De bewijskracht van die informatie is afhankelijk van de betrouwbaarheid van de informatie zelf en de betrouwbaarheid van de bron van die informatie.

De betrouwbaarheid van de informatie kan worden gemeten aan zijn innerlijke consistentie, gedetailleerdheid en uiterlijke consistentie. De uiterlijke consistentie bestaat uit de mate van overeenstemming met andere informatie.

Voorbeelden van onbetrouwbare bronnen zijn: getuigen die contacten onderhouden met de onderwereld en om die reden bijvoorbeeld belang hebben bij de veroordeling van de verdachte; een slechtziende getuige die verklaart in het donker en over grote afstand bepaalde dingen te hebben gezien; en officiële stukken die vervalst blijken te zijn, enzovoorts. De betrouwbaarheid van de bron heeft gevolgen voor de betrouwbaarheid van de daardoor verstrekte informatie.

Alleen wanneer de rechter de bron zelf ziet en/of hoort kan hij zich een eigen indruk vormen van de betrouwbaarheid daarvan en (daarmee) van de betrouwbaarheid van de gegeven informatie. De rechter kan in het bijzijn van de bron zijn informatie ter discussie stellen. Belangrijk is dat de verdediging aan die discussie kan 
deelnemen. De voor de controle van de betrouwbaarheid van de informatie noodzakelijke discussie en de concentratie van het onderzoek ter terechtzitting eisen dat het onderzoek mondeling wordt gevoerd. De mondelinge behandeling is bovendien nodig vanwege de procespsychologische aspecten van het debat voor de bewijswaardering. Toon, wijze van uitdrukking, gehaastheid of twijfel bij het spreken spelen daarbij een rol. Dat geldt evenzeer voor de visuele aspecten van de gevoerde discussie. Toch mag de rechter niet alleen op deze visuele en auditieve aspecten van het debat afgaan. Non-verbale communicatie is niet altijd eenduidig en kan daarom misleidend zijn ${ }^{\text {tiu. }}$. De verdachte of getuige die na het stellen van een vraag rood aanloopt en niet goed uit zijn woorden komt, vertelt niet per definitie om die reden een onwaarheid. De emotionele indruk die een getuige op een bepaald moment geeft, kan bovendien moeilijk als indicatie voor diens gedrag, houding of karakter in het algemeen gelden. Daarom dient de rechter de non-verbale communicatie steeds te interpreteren tegen de achtergrond van de betrouwbaarheid van de verstrekte informatie zelf.

Een andere reden om voorzichtig te zijn met het trekken van conclusies uit nonverbale communicatie is gelegen in het ontbreken van het contradictoire element ten aanzien van de waarneming ${ }^{105}$ daarvan door de rechter ${ }^{106}$. Een vraag die in het verlengde van deze constatering ligt, is in hoeverre de rechter deze waarneming expliciet ter discussie dient te stellen. In dit verband wordt herinnerd aan Geppert, die van mening is dat uit het onmiddellijkheidsbeginsel voortvloeit dat alles wat op het oordeel van de rechter van invloed is, ter zitting ter discussie gesteld dient te worden. Ik ben van mening dat een dergelijke eis te ver gaat. Ook van de verdediging mag worden geëist dat zij alert blijft en haar verdediging ook op de non-verbale communicatie toespitst wanneer zij meent dat deze bij de oordeelsvorming een belangrijke rol speelt. Bovendien zal de rechter zich niet steeds bewust zijn van de invloed die de non-verbale communicatie op zijn oordeel heeft (gehad). Verder kun je je afvragen in hoeverre een discussie over de interpretatie van non-verbale communicatie ergens toe leidt. Waarschijnlijk leidt zij niet tot duidelijkheid maar eerder tot afleiding van waar het om te doen is, de betrouwbaarheid van de door de getuige verstrekte informatie. Dit doet er echter niet aan af, dat de rechter ervoor dient te waken zijn oordeel over de betrouwbaarheid van de verstrekte informatie in belangrijke mate te baseren op houding en presentatie van de verklarende persoon. Wenst de rechter informatie over de persoon van de getuige of de verdachte dan staan

104 Zie hierover bijvoorbeeld U. Undeutsch (1983), Vernehmung und non-verbale-Information, In: E. Kube, H.U. Störzer u. S. Brugger (Hrsgg.), Wissenschaftliche Kriminalistik, Teilband 1 BKAForschungsreihe 16/1, Wiesbaden: Bundeskriminalamt, p. 389 $\mathrm{t} / \mathrm{m} 418$. Zie hierover ook W.L. Borst, De bewijsmiddelen in strafzaken, Arnhem 1985, p. 83.

$105 \mathrm{lk}$ heb het hier over de waarneming van de non-verbale communicatie die een rol kan spelen bij de waardering van een getuigenverklaring. Ik heb het niet over de waarneming van de rechter in de zin van bewijsmiddel ex art. $340 \mathrm{~Sv}$. Voor zover de rechter zijn eigen waarneming als bewijsmiddel wenst te gebruiken, dient hij deze waarneming op de zitting ter discussie te stellen.

106 Zie ook W.L. Borst (1985), a.w., p. 84. 
hem daartoe andere en meer betrouwbaardere middelen ter beschikking dan zijn persoonlijke indrukken ter zitting.

Hoewel dit niet direkt te maken heeft met de eigen indruk van de rechter, kan in dit verband ook worden gewezen op het gebruik van de kennisneming door de rechter van de stukken uit het vooronderzoek. Volgens Geppert staat ook dit op gespannen voet met het onmiddellijkheidsbeginsel, omdat van die kennisneming hoogstwaarschijnlijk wel invloed uitgaat op het waarderingsproces van de rechter maar dit niet op de zitting ter discussie wordt gesteld. Maar ook hier bestaat de moeilijkheid dat de vraag in hoeverre en op welke manier de kennis van de processtukken meespeelt bij de waardering van het ter zitting gepresenteerde bewijs, - ook voor de rechter - nauwelijks valt te beantwoorden. Een discussie daarover ter zitting is mijns inziens niet enkel vruchteloos maar ook zinloos. Wat van belang is, is de onbevangenheid van de rechter. Onbevangen zijn is minder een feitelijke hoedanigheid als wel een mentale gemoedstoestand ${ }^{107}$. Het allerbelangrijkste aspect daarvan is gelegen in de omstandigheid dat de rechter zich voortdurend bewust is van de feilbaarheid van zijn aanvankelijke oordeel waartoe hij mogelijk op grond van het procesdossier is gekomen. Het is om die reden dat de rechter zelf de wens zal moeten hebben om, alvorens tot een oordeel te komen, het door de officier van justitic gepresenteerde verhaal uit de stukken te toetsen door het daarvoor aangedragen hewijsmateriaal op zijn inhoud en kwaliteit te controleren in een contradictoire 'setting'. Maar meer dan dat kan volgens mij van de rechter niet worden geëist.

\subsection{Gebruik van stukken uit het vooronderzoek en controleerbaarheid}

Wanneer de ratio van het onmiddellijkheidsbeginsel is gelegen in de controleerbaarheid van het bewijs, betekent dit dan noodzakelijkerwijs dat alle stukken uit het vooronderzoek hun waarde voor het bewijs hebben verloren? Essentieel is dat de rechter het bewijs op zijn betrouwbaarheid en kwaliteit heeft kunnen toetsen. Maar die toetsing lijkt in principe ook mogelijk ten aanzien van middellijke informatie. Daarvoor is dan echter wel weer vereist dat de rechter de oorspronkelijke bron van die informatie zelf ziet en/of hoort. Want alleen aan de hand van de oorspronkelijke bron van de informatie kan de rechter controleren of de informatie volledig en correct is overgebracht. En alleen met behulp van de oorspronkelijke bron kan hij zich een cordeel vormen over de kwaliteit en betrouwbaarheid van de overgebrachte informatie. De mogelijkheid om de overgebrachte informatie ter discussie te stellen, aan

107 Zie hierover ook J. Leijten, De verschikkelijke eenzaamheid van de inbreker, Nijmegen 1992, p. 68, dic over onbevangenheid schrijft: "Ik zou denken dat het allerbelangrijkste aspect daarvan is dat de rechter niet persoonlijk bij de zaak van de verdachte betrokken is ên zich niet persoonlijk bij de zaak betrokken voclt." Niet bij de zaak betrokken zijn is cen feitelijke hoedanigheid. Niet bij de zaak betrokken voelen is een mentale gemoedstoestand. Het laatste is mijns inziens nog belangrijker dan het eerste. 
welke discussie ook de verdediging kan deelnemen, en de eigen indruk die de rechter tijdens het debat opdoet van de oorspronkelijke bron en de kwaliteit van de overgebrachte informatie, zijn wederom cruciaal. Maar wanneer de rechter het procesverbaal met de daarin opgenomen getuigenverklaring in het bijzijn van de betreffende getuige en de verdachte ter discussie heeft gesteld en op die manier op zijn waarde voor het bewijs heeft getoetst, lijkt er geen reden waarom dit proces-verbaal niet aan het oordeel van de rechter ten grondslag zou mogen worden gelegd.

Toch moet hier wel worden gewezen op het gevaar dat de getuige, door de lange tijd die er is verlopen tussen het gebeurde en de getuigenverklaring bij de politie enerzijds en het onderzoek ter terechtzitting anderzijds, zich ter terechtzitting van het voorval nog maar weinig kan herinneren. Wanneer de getuige ter zitting herhaaldelijk verklaard het niet meer te weten, wordt controle van de overgebrachte informatie uit het proces-verbaal problematisch. Tegen het gebruik van het proces-verbaal voor het bewijs kan in zo'n geval bovendien worden aangevoerd dat ook de verdediging geen echte kans heeft gehad de overgebrachte informatie aan te vechten wanneer deze niet ook bij het verhoor van de getuige tijdens het vooronderzoek aanwezig heeft kunnen zijn. Het gevolg is dat de rechter dan zowel de getuigenverklaring ter zitting als ook de overgebrachte getuigenverklaring uit het proces-verbaal wegens oncontroleerbaarheid conform het onmiddellijkheidsbeginsel niet mag laten meewerken tot het bewijs. Of de rechter de overgebrachte verklaring al dan niet voldoende heeft kunnen controleren is daarbij overgelaten aan zijn oordeel, maar dit voorbeeld maakt wel duidelijk waarom het onmiddellijkheidsbeginsel ook eist dat tussen het constateren van een strafbaar feit en het onderzoek ter terechtzitting zo min mogelijk tijd verloren gaat.

\subsection{Controleerbaarheid van het bewijs en de niet meewerkende verdachte}

Het onmiddellijkheidsbeginsel eist dat de verdachte ter zitting aanwezig is. Essentieel voor de controleerbaarheid van de betrouwbaarheid en kwaliteit van het bewijs is dat de verdediging zijn inzichten hieromtrent heeft kunnen kenbaar maken. Maar wat zijn de consequenties van het onmiddellijkheidsbeginsel wanneer de verdachte ter zitting niet verschijnt dan wel aanwezig is maar gebruik maakt van zijn zwijgrecht? ${ }^{108}$ Wanneer de verdediging niet wenst mee te doen aan de discussie ter terechtzitting over de kwaliteit en betrouwbaarheid van het gepresenteerde bewijs, wordt de controle van het bewijs voor de rechter bemoeilijkt. De rechter zal het

108 Wanneer de verdachte ter zilling gebruik maakt van zijn zwijgrecht of niet verschijnt, betekent dat overigens nog niet dat ook zijn raadsman geen verdediging voor hem zou mogen en kunnen voeren. Zie in dit verband ook: ECRM rapporten van 4 mei 1903 in de zaken Radjinderpersad Roy Lala tegen Nederland en S.P. tegen Nederland: E. Myjer, De raadsman en de afwezige verdachte, NJCM-bulletin 1993, p. $811 \mathrm{t} / \mathrm{m}$ 822; Poitrimol zaak, EHRM 23 november 1993, Serics A, vol. $277-\mathrm{A}$. 
moeten stellen met de eigen indruk die hij bij zijn waarneming van het bewijs heeft naast de mogelijkheden die hij heeft wanneer het bewijs bestaat uit een verklaring van getuige, deskundige of medeverdachte, om de zegsman daarvan alleen zelf te ondervragen en deze met ander bewijs te confronteren. Puur vanwege het feit dat anders de verdachte elke oordeelsvorming van de rechter over zijn betrokkenheid bij een strafbaar feit zou kunnen frustreren mag het onmiddellijkheidsbeginsel niet zo worden uitgelegd dat dan de rechter het voorhanden zijnde bewijs niet aan zijn oordeel ten grondslag zou mogen leggen. Het moet aan het oordeel van de rechter worden overgelaten of hij op grond van de beperktere controle het bewijs voldoende betrouwbaar acht om daarop zijn oordeel te vellen.

\subsection{Definitie van het onmiddellijkheidsbeginsel}

Het onmiddellijkheidsbeginsel is voortgekomen uit het streven naar een optimale waarheidsvinding. De waarheidsvraag in het strafproces hangt echter uitsluitend af van de bewijzende betekenis die men aan de voorhanden zijnde bewijsmiddelen toekent ${ }^{100}$. Dat kan niet anders omdat hetgeen in het verleden heeft plaatsgevonden nooit meer met absolute zekerheid kan worden achterhaald. In de persoon van de onafhankelijke rechter wordt een waarborg gezien voor een onpartijdig en objectief oordeel en daarom is de bewijswaardering aan hem opgedragen. Het onmiddellijkheidsbeginsel schept de voorwaarden voor een zelfstandige en uit een oogpunt van waarheidsvinding zo goed mogelijke rechterlijke bewijswaardering. Op grond van de uit de literatuur afgeleide informatie en rekening houdend met de hiervoor gemaakte opmerkingen over de reikwijdte ervan kom ik tot de volgende omschrijving van het onmiddellijkheidsbeginsel:

Met het onmiddellijkheidsbeginsel wordt bedoeld de eis, dat alle oorspronkelijke bewijsbronnen ter terechtzitting ten overstaan van de rechter en (bij voorkeur) in het bijzijn van de verdachte worden gepresenteerd, opdat de rechter alleen dat bewijs aan zijn oordeel ten grondslag legt, waarvan hij zelfstandig de kwaliteit en betrouwbaarheid heeft kunnen controleren a) door middel van zijn eigen waameming van de oorspronkelijke bron (visueel en/of auditief); b) (zo mogelijk) door middel van de ondenvaging van de oorspronkelijke bron en c) door middel van de confrontatie van de oorspronkelijke bewijsbron en zijn informatie met ander bewijs en/of (zo mogelijk) de verdediging.

109 Zic onk A.L. Melai, Het waarheidsprobleem in het strafproces, In: Handclingen van de vereniging voor Wijsbegeerte des Rechts 1961, Zwolle 1961, p. 66 cn 67. 
Het onmiddellijkheidsbeginsel kan worden gezien als een bewijsbeginsel, maar ook als een structuurbeginsel. Gebrek aan dit inzicht is oorzaak van veel onduidelijkheid over de reikwijdte van het onmiddellijkheidsbeginsel.

Opgevat als bewijsbeginsel heeft het alleen betrekking op de bewijsbeslissing in het strafproces ${ }^{110}$.

Vat men het onmiddellijkheidsbeginsel op als een structuurbeginsel dan heeft het niet alleen betrekking op de bewijsbeslissing maar tevens implicaties voor uiteenlopende andere beginselen die aan het strafproces ten grondslag liggen.

Zo wezen Reijntjes en Mols, maar ook reeds Mittermaier, op het belang van het onmiddelijkheidsbeginsel voor het (interne en/of externe) openbaarheidsbeginsel. Een strafproces dat niet of onvoldoende tegenmoet komt aan het onmiddellijkheidsbeginsel doet afbreuk aan het (interne en/of externe) openbaarheidsbeginsel.

Mols en - hoewel minder duidelijk - ook F.F. Langemeijer wezen op het belang van het onmiddellijkheidsbeginsel voor het beginsel van contradictoire procesvoering. Een strafproces dat gevoerd wordt op basis van schriftelijke stukken, dat wil zeggen gereproduceerd bewijs, kan best op tegenspraak worden gevoerd. De verdediging kan alles aanvoeren dat zij van belang acht. Werkelijk inhoud krijgt het beginsel van contradictoire procesvoering eerst als het proces onmiddellijk gevoerd en daarmee ook intern openbaar wordt. Ook Mittermaier"' en Von Feuerbach erkenden dit al. Illustratief zijn de woorden van Von Feuerbach: "(..) Protokolle legen wenigstens wider sich selbst kein Zeugnis ab. Klagt aber der Angeschuldigte das Protokoll und den Richter an, so können die stummen Wände für ilın ke'in Zeugniß gehen. ${ }^{\text {n'2 }}$

Mols wees ook op het belang van het onmiddellijkheidsbeginsel voor de autonoom rechterlijke functie. Objectiviteit en onpartijdigheid worden beter beschermd naar mate het proces onmiddellijker wordt gevoerd. Daarbij is belangrijk dat Mols het belang van het onmiddellijkheidsbeginsel voor de rechterlijke onafhankelijkheid ook noemt in het kader van de rechterlijke controle op het overheidsoptreden ${ }^{113}$. Niet

110 Geppert optecrt ervoor om het onmiddellijkheidsbeginsel op te vatten als cen bewijsbeginsel omdat het volgens hem alleen dan kan worden onderscheiden van andere strafprocessuele beginselen zoals het beginsel van mondelinge procesvoering. Zie K. Geppert (1979), a.w., p. $136 \mathrm{t} / \mathrm{m} 145$.

$111 \mathrm{Zie} \$ 3.1$. van dit hoofdstuk over hetgeen Mittermaier schreef ten aanzien van het verdedigingsrecht van de beschuldigde, die pas in een onmiddellijk gevoerd proces zijn ware betekenis krijgt. CJ.A. Mittermaier (1845), a.w., p. 251 en 252.

112 A.R. Von Feuerbach (1821), a.w., p. 165.

$113 \mathrm{Zie}$ in dit verband ook: GJ.M. Corstens, De verhouding rechter - openbaar ministeric; een lal-rclatic in het strafrecht, Arnhem 1983, p. 26: "(..) de rechterlijkc onafhankclijkhcid. Dic onafhankelijkhcid is niet aan de rechter gegeven om zijn of haar aanzien te vergroten. Onafhankelijkheid is te verstaan als een opdracht aan de rechter. De rechtsgrond van de onafhankclijkheid is in de sfeer van de strafrechtspleging te zoeken in het waarborgen van de vrijheid van de burger, in het waarborgen van rechten van de burger tegenover de staat. De rechter wordt in strafzaken voortdurend geroepen tot oordelen over bevoegdhcidsuitocfening door de overheid ten opzichte van burgers. Bij dit 
alleen de controle op het door de officier van jusitie gepresenteerde verhaal ter zitting (waarheidsvinding), maar ook de controle op de wijze waarop het openbaar ministerie tot dat verhaal is gekomen (de rechtmatigheid van de bewijsgaring) eist dat de rechter de verstrekte informatie toetst aan de hand van de oorspronkelijke bron daarvan en in een contradictoire 'setting'.

Zo bezien vormt het onmiddellijkheidsbeginsel een structuurbeginsel dat inhoud geeft aan vele andere beginselen die aan ons strafproces ten grondslag liggen. Immers zonder het onmiddellijkheidsbeginsel verliezen deze andere beginselen veel van hun waarde.

Is het onmiddellijkheidsbeginsel een bewijsbeginsel of een structuurbeginsel? Het is beide. Ik zou het liever willen formuleren als volgt. Het onmiddellijkheidsbeginsel is een bewijsbeginsel waarvan de mate waarin het erkenning vindt consequenties heeft voor de gehele structuur van ons strafproces.

\section{Conclusie}

Het onmiddellijkheidsbeginsel is een bewijsbeginsel waarvan de mate van erkenning gevolgen heeft voor de gehele structuur van het strafproces. Het onmiddellijkheidsbeginsel eist dat alle oorspronkelijke bewijsbronnen terterechtzitting ten overstaan van de rechter en (bij voorkeur) in het bijzijn van de verdachte worden gepresenteerd, opdat de rechter alleen dat bewijs aan zijn oordeel ten grondslag legt, waarvan hij zelfstandig de kwaliteit en betrouwbaarheid heeft kunnen controleren

a. door middel van zijn eigen waarneming van de oorspronkelijke bron (visueel en/of auditief);

b. (zo mogelijk) door middel van de ondervraging van de oorspronkelijke bron en

c. door middel van de confrontatie van de oorspronkelijke bewijsbron en zijn informatie met ander bewijs en/of (zo mogelijk) de verdediging.

Een strafproces dat in onvoldoende mate tegemoet komt aan het onmiddellijkheidsbeginsel doet in dezelfde mate afbreuk aan zijn openbaarheid, het uitgangspunt van de scheiding der machten en zijn contradictoire karakter. Waar elk uitgangspunt afzonderlijk - in onderling verband geldt dit nog sterker - beoogt een bijdrage te leveren aan het rechtsgehalte van het strafrecht ten behoeve van een rechtvaardige juridische strafrechtspleging, betekent elke relativering van het onmiddellijkheidsbeginsel een aantasting daarvan ${ }^{114}$.

oordelen zal hij steeds moeten nagaan of individucle rechten op ontoclaatbare wijze geschonden zijn of aangetast dreigen te worden."

114 G.P.M.F. Mols (1989), a.w., p. 8. 


\section{Het onmiddellijkheidsbeginsel in ons strafproces sinds 1926}

\section{Inleiding}

In 1926 trad ons huidige Wetboek van Strafvordering in werking. De redenen om tot een algehele herziening van het Wetboek van Strafvordering van 1838 te komen, waren vooral gelegen in de onvrede met de in dit wetboek "verouderde van het vooronderzoek. "De beklaagde werd (daarin) gemaakt tot voorwerp van onderzoek; dat onderzoek was geheim ook tegenover de beklaagde; het recht op verdediging werd tijdens het vooronderzoek niet erkend, alle beslissingen van raadkamer, van hof en rechtbank werden genomen op grond van de schriftelijke stukken, zonder dat de beklaagde door den beschikkenden rechter werd gehoord of in staat werd gesteld zijne belangen mondeling te doen verdedigen. ${ }^{2}$ Met andere woorden, met de herziening van het Wetboek van Strafvordering 1838 werd onder andere beoogd het vooronderzoek in strafzaken onmiddellijker ${ }^{3}$ te maken of zoals de Memorie van Toelichting dat uitdrukt: "zal die herziening allereerst ten doel moeten hebben eene zoodanige wijziging van het vooronderzoek, dat ook in dat gedeelte van het strafproces met de zelfstandige rechten van den verdachte wordt rekening gehouden en die rechten in zoodanigen omvang worden erkend en gewaarborgd als met het doel van het strafproces, de verzekering van toepassing van de strafwet op den schuldige, in overeenstemming kan worden geacht."

Ten aanzien van de beginselen van openbaarheid en mondelinge procesvoering blijkt het streven van de wetgever voor het nieuwe wetboek overduidelijk: "alles wai de zelfstandige waarde van de mondelinge, in de regel openbare eindbehandeling kan verhoogen, verdient door den wetgever te worden bevorderd. Het voorbereidend onderzoek moet ook werkelijk enkel voorbereidend zijn."

1. Zie MvT ORO WvSv TK 1913-1914, 286, nr. 3, p. 3.

2 MvT ORO WvSv, TK 1913-1914, 286, nr. 3, p. 2.

3 Dat wordt ook nog met zoveel wourden gezegd: "en in het algemeen de bevordering der ze "onmiddellijkheid" ook tijdens het vooronderzoek". Zie MvT ORO WvSv, 'TK 1913-1914, 286, nr. 3, p. 11.

4 MvT ORO WvSv, TK 1913-1914, 280, nr. 3, p. 3.

5 MvT ORO WvSv, TK 1913-1914, 286, nr. 3, p. 23. 
Wat het bewijsstelsel aangaat is in dit wetboek niet afgeweken van het uitgangspunt dat ook ten grondslag lag aan het Wetboek van Strafvordering 1838: "de rechtermag eenig feit slechts dàn als bewezen aannemen, wanneer hij daawan uit het onderzoek ter terechtzitting door den inhoud van wettige bewijsmiddelen de overtuiging heeft bekomen."

In dit hoofdstuk wordt uiteengezet hoe het onmiddellijkheidsbeginsel tot zijn recht kwam in de opzet van het strafproces volgens het Wetboek van Strafvordering van 1926. Hoewel het onmiddellijkheidsbeginsel zich verzet tegen de reproduktie van elke vorm van bewijs, spitst deze uiteenzetting zich toe op de reproduktie van de getuigenverklaring, omdat dit bewijsmiddel ook in het moderne strafproces nog steeds een centrale plaats inneemt - zeker als de verdachte niet (volledig) bekend en bij dit bewijsmiddel de problemen rond de controleerbaarheid van informatie bij reproduktie het grootst zijn. Daarop volgt een bespreking van het zo genoemde 'De auditu'-arrest. Deze uitspraak heeft grote consequenties gehad voor de inrichting van het eindonderzoek en de mate waarin aan het onmiddellijkheidsbeginsel in ons strafproces inhoud wordt gegeven. Ik ben op zoek gegaan naar een antwoord op de vraag hoe deze uitspraak tot stand heeft kunnen komen. In dat verband komt ook de betekenis van het negatief wettelijk bewijsstelsel aan de orde. Ten slotte zal worden aangegeven waartoe het 'De auditu'-arrest heeft geleid en hoe het tegenwoordig is gesteld met de onmiddellijkheid van ons strafproces.

\section{Het onmiddellijkheidsbeginsel in de opzet van ons huidig strafproces}

Uit hoofdstuk éen blijkt dat het onmiddellijkheidsbeginsel gezien moet worden als een bewijsbeginsel waarvan de mate waarin het erkenning vindt consequenties heeft voor de gehele structuur van ons strafproces. Op zoek naar het antwoord op de vraag hoe het onmiddellijkheidsbeginsel in de opzet van ons huidige strafproces was uitgewerkt, ligt het dan ook voor de hand de wettelijke bewijsregeling aan een nader onderzoek te onderwerpen. De wettelijke voorschriften betreffende het bewijs zijn neergelegd in de artt. 338 tot en met $344 \mathrm{a}$ Sv.

\subsection{De wettelijke bewijsregeling}

In het vorige hoofdstuk kwam reeds naar voren dat verschillende rechtsgeleerde schrijvers van mening zijn, dat het onmiddellijkheidsheginsel ten grondslag ligt aan art. $338 \mathrm{~Sv}^{7}$. Dit artikel luidt:

7 Zie de opvattingen van bijvoorbeeld F.F. Langemeijer en J.M. Reijntjes weergegeven in hoofdstuk 2, resp. $\$ 5.3 \mathrm{en} \$ 5.5$. Zie ook A. Minkenhof, De Nederlandse strafvordering, Alphen a/d Rijn 1981, vierde herziene druk, p. 239; T.M. Schalken, De strafrechter en de anonieme getuige, In: 
"Het bewijs dat de verdachte het telastegelegde feit heeft begaan, kan door de rechter slechts worden aangenomen, indien hij daavan uit het onderzoek op de terechtzitting door de inhoud van wettige bewijsmiddelen de overtuiging heeft bekomen."

Uit deze bepaling lijkt inderdaad voort te vloeien dat de rechter persoonlijk dient kennis te nemen van de bewijsmiddelen. Op de keper beschouwd geeft zij echter alleen antwoord op de vraag wie subject van de bewijsbeslissing dient te zijn: de rechter ter terechtzitting. Over de kwestie wat object van de bewijsbeslissing dient te zijn, geeft dit voorschrift immers geen uitsluitsel. Wat zijn 'wettige bewijsmiddelen'? Wordt daaronder alleen origineel bewijs begrepen of valt daaronder ook gereproduceerd bewijs? Het antwoord op deze vraag wordt mogelijk gevonden in art. $339 \mathrm{~Sv}$. Als 'wettige bewijsmiddelen' worden volgens deze bepaling alleen erkend:

a. de eigen waarneming van de rechter;

b. de verklaring van de verdachte;

c. de verklaring van een getuige;

d. de verklaring van een deskundige en

e. schriftelijke bescheiden.

De Memorie van Toelichting zegt over deze opsomming: "De hier genoemde middelen, (..) vormen den weg waarlangs uitsluitend de feiten, door welke het te laste gelegde feit bewezen kan worden, in het geding worden gebracht. Zij vormen een vij volledige opsomming van hetgeen als bewijsmiddel in aanmerking kan komen: de rechter toch kan alleen oordelen over hetgeen hij of zelf heeft waargenomen of door een ander is waargenomen en hem is medegedeeld. "En verder: "Eene opsomming der bewijsmiddelen is noodig om te voorkomen, dat de rechter hetzij op gevoelsindrukken, hetzij op bewijsmiddelen, wier betrouwbaarheid reeds door hun oorsprong wordt uitgesloten, zal recht doen. (..) Bovendien verzekert eene wettelijke opsomming der bewijsmiddelen de gelijkheid van rechtspleging, terwijl bij gebreke daarvan de eene rechter als bewijsmiddel zou toelaten wat door den ander wordt verworpen."

Eigenlijk biedt deze informatie nog weinig duidelijkheid, behalve dan dat bij de keuze van wat als bewijsmiddel kan dienen, de betrouwbaarheid van het middel blijkbaar een rol heeft gespeeld. Maar of dat voldoende is om te concluderen dat als verklaring van de verdachte, een getuige of een deskundige alleen bedoeld wordt de verklaringen van deze personen in hun originele vorm, zodat bijvoorbeeld de door een derde opgeschreven verklaring van een getuige, een door de getuige zelf op schrift gestelde verklaring als ook de door een derde mondeling weergegeven

Beginselen, Arnhem 1981, p. 329, J.F. Nijbocr, Algemenc grondslagen van de bewijsbeslissing in het Nederlandse strafprocesrecht, Arnhem 1982, art. 338, aant. 12, p. 20 en 21; N. Jörgen C. Kelk, Strafrecht met mate, Alphen a/d Rijn 1990, 7e druk, p. 257; G.J.M. Corstens, Het Nederlandse strafprocesrecht, Arnhem 1993, p. 58.

8 MvT ORO WvSv, TK 1913-1914, 286, nr. 3, art. 332, p. 167.

9 MvT ORO WvSv, TK 1913-1914, 286, nr. 3, Derde afdeling. Bewijs, p. 164. 
verklaring van een getuige (de verklaring van horen zeggen ofwel de verklaring 'de auditu' genoemd) niet als geldig bewijsmiddel kunnen gelden?

Gelukkig bevat de wet ook de specifieke omschrijving waaraan elk wettig bewijsmiddel moet voldoen. Deze definities van de afzonderlijke bewijsmiddelen zijn te vinden in de artt. 340 tot en met 344 Sv. Zo bepaalt art. 342 lid 1 Sv bijvoorbeeld: "Onderverklaring van een getuige wordt verstaan zijn bij het onderzoek ter terechtzitting gedane mededeling van feiten en omstandigheden, welke hij zelf waargenomen of ondervonden heeft."

\subsection{Vier elementen van de getuigenverklaring}

Borst onderscheidt daan de wettelijke definitie van de getuigenverklaring vier elementen, die elk een norm uitdrukt waaraan de uitlating moet voldoen om als "bewijsmiddel" in de zin van de wet te kunnen worden aangemerkt. Deze elementen zijn:
a. "eigen";
b. "waargenomen of ondervonden";
c. "feiten of omstandigheden";
d. "bij het onderzoek ter terechtzitting"

ad a. Het eerste element kan volgens Borst opgevat worden als de vraag, of de kennis die de getuige aandraagt oorspronkelijk is dan wel aan anderen ontleend".

ad b. Het tweede element kan men volgens hem interpreteren als de vraag naar de mate van zekerheid die moet worden geëist met betrekking tot de door de getuige verstrekte informatie. Dit element heeft vooral de strekking allerhande gissingen, vermoedens, veronderstellingen, aannamen en dergelijke te wraken als bewijsmiddel. Alle informatie die in de voorstelling van de getuige die haar aandraagt niet met een redelijke mate van zekerheid voor juist moet worden gehouden, moet als bewijs worden verworpen ${ }^{12}$.

ad c. Het begrippenpaar 'feiten en omstandigheden', dat het derde element vormt, moet volgens de schrijver zo worden opgevat dat het ertoe strekt conclusies, redeneringen, meningen, beschouwingen, visies, opvattingen en oordelen van de getuige te weren ${ }^{3}$.

10 W.L. Borst, De bewijsmiddelen in strafzaken, Arnhem 1985, p. 35.

11 W.L. Borst (1985), a.w., p. 36.

12 W.L. Borst (1985), a.w., p. 36.

13 W.L. Borst (1985), a.w., p. 36. 
Het onderscheid tussen het eerste en derde element kan men typeren als het onderscheid hoe de getuige iets te weten is gekomen en wat hij/zij weet ${ }^{\text {t4 }}$. Het onderscheid tussen het tweede en derde element verduidelijkt Borst als volgt: het tweede element heeft ten doel gissingen uit te sluiten als onvoldoende solide 'bouwstenen' voor het rechterlijk bewijsoordeel, terwijl het derde element ertoe strekt de monopoliepositie van de rechter met betrekking tot het oordeel en de beslissing veilig te stellen door meningen van anderen dan de rechter als contrabande te weren's

ad d. Als vierde element rest nog de norm dat de getuigenverklaring moet zijn afgelegd "bij het onderzoek ter terechtzitting". Omdat ook art. 338 Sv reeds bepaalt dat ieder bewijsmiddel bij het onderzoek ter terechtzitting moet zijn geopenbaard, komt Borst tot de conclusie, dat, wil men aan dit element zelfstandige betekenis toekennen, in die zin dat de omschrijving van dit bewijsmiddel door dit element niet tautologisch wordt, dit element er alleen toe kan strekken dat niet oorspronkelijke verklaringen (van horen zeggen) voor het bewijs worden geweerd ${ }^{16}$.

\subsection{De mondelinge en schriftelijke getuigenverklaring}

Wat opvalt is dat Borst er stilzwijgend vanuit gaat dat de door de getuige "bij het onderzoek op de terechtzitting gedane mededeling" (art. 342 lid 1 Sv) volgens de wetgever in mondelinge vorm dient te geschieden. Hier is echter op basis van grammaticale interpretatie geen dwingende reden toe. Een mededeling kan ook in schriftelijke vorm geschieden.

Toch is het wel waarschijnlijk dat de wetgever bij het redigeren van art. 342 lid 1 Sv de "mededeling" in mondelinge vorm voor ogen heeft gestaan. Dat stemt immers overeen met de aan het nieuwe wetboek ten grondslag liggende opvatting dat "alles wat de zelfstandige waarde van de mondelinge, in de regel openbare eindbehandeling kan verhogen, verdient (..) te worden bevorderd ${ }^{m ?}$.

Bovendien verklaart het waarom de wetgever, voor zover het onder meer betreft een getuigenverklaring van een opsporingsambtenaar, op dit uitgangspunt een uitdrukkelijke uitzondering heeft toegelaten. Art. 344 lid 1 sub $2 \mathrm{~Sv}$ bepaalt immers dat processen-verbaal en andere geschriften die in de wettelijke vorm zijn opgemaakt door personen of colleges die daartoe bevoegd zijn en die hun mededeling bevatten van feiten en omstandigheden die door hen zelf zijn waargenomen of ondervonden, kunnen worden aangemerkt als een wettig bewijsmiddel. In deze bepaling wordt de "mededeling" bedoeld in zijn schriftelijke vorm. Uit de Memorie van Toelichting

14 W.L. Borst (1985), a.w., p. 37.

15 W.L. Borst (1985), a.w., p. 38.

16 W.L. Borst (1985), a.w., p. 39.

17 MvT ORO WvSv, TK 1913-1914, 286, nr. 3, p. 23. 
blijkt dat de wetgever heeft erkend dat het bij deze processen-verbaal van bijvourbeeld opsporingsambtenaren om niets anders gaat dan "in schrift gehrachte getuigenverklaringen $n^{\text {thx }}$. De wetgever was echter van oordeel dat deze schriftelijke getuigenverklaringen om praktische redenen ${ }^{19}$ moeten, maar ook, mede dankzij de functie van de persoon door wie zij zijn opgemaakt, qua betrouwbaarheid op één lijn kúnnen worden gesteld met ter zitting afgelegde mondelinge getuigenverklaringen ${ }^{20}$.

Concluderend kan worden gesteld dat vor zover het gaat om getuigenverklaringen op grond van de wettelijke bewijsregeling een getuige ter zitting zijn verklaring mondeling dient af te leggen, wil deze verklaring door de rechter aan zijn oordeel ten grondslag kunnen worden gelegd. In zoverre beantwoordt de wettelijke bewijsregeling aan het onmiddellijkheidsbeginsel. Op deze regel bestaat echter een belangrijke uitzondering voor zover het onder meer getuigenverklaringen van opsporingsambtenaren betreft ${ }^{21}$. De rechter mag deze verklaringen ook in schriftelijke door de oorspronkelijk bron zelf gereproduceerde vorm aan zijn oordeel ten grondslag leggen.

\subsection{De mondelinge dan wel schriftelijke getuigenverklaring van horen zeggen}

Een ander probleem betreft de vraag in hoeverre een (mondelinge danwel schriftelijke) getuigenverklaring dient te bestaan uit originele informatie, dat wil zeggen informatie die niet aan een ander is ontleend. Het is met name deze vraag waarop het hoven weergegeven betoog van Borst hetrekking heeft. Hij komt tot de conclusie dat art. 342 lid $1 \mathrm{~Sv}$ het gehruik door de rechter van een mondelinge verklaring van horen zeggen voor het bewijs uitsluit. Hoewel de interpretatie van art. 342 lid $1 \mathrm{~Sv}$ door Borst helder en plausibel voorkomt ${ }^{22}$, biedt de Memorie van Toelichting echter

18 MvT ORO WvSv, TK 1913-1914, 286, nr. 3, p. 173.

19 Zie MvT ORO WvSv, TK 1913-1914, 286, nr. 3, p. 166.

20 MvT ORO WvSv, TK 1913-1914, 286, nr. 3, p. 171. Zie ook: E. Polak, De bewijskracht van het proces-verbaal van den opsporingsambtenaar, TvS 1927, p. $151 \mathrm{t} / \mathrm{m} 169$.

21 Zie MvT ORO WvSv, TK 1913-1914, 286, nr. 3, p. 172: "Het voorschrift is niet beperkt tot de eigenlijke processen-verbaal van opsporingsambtenaren, doch omvat mede alle relazen, verbalen, acten enz van nasporingsambtenaren als ambtenaren van het openbaar ministerie, rechter-commissarissen, griffiers en van de personen, die bij enige bijzondere wet of wettelijk voorschrift zijn belast met of bevoegd verklaard tot het relateren van bepaalde feiten, gelijk notarissen, deurwaarders, voorzitters van stemburcau's enz."

22 Deze opvatting over de juiste interpretatic van art. 342 lid 1 Sv lijkt door anderen ook te worden gedeeld. Zie bijvoorbeeld J.F. Nijboer, Inleiding tot het strafrechtelijk bewijsrecht, Nijmegen 1992, vierde druk, p. 43: "Het is aannemelijk dat de makers van het Wetbock van Strafvordering een wijze van procesvoering voor ogen heeft gestaan, waarin het accent ligt op een mondelinge overdracht van informatie en gedachtenwisseling ter terechtzitting. De persoonlijke confrontatie van rechter, officier van justitie en verdachte onderling èn met derden-informanten is in die voorstelling van zaken bij het tot stand komen van de verklaringen die ter zitting worden afgelegd en bij de bespreking van uit het vooronderzoek afkomstige onderzoeksresultaten van groot belang." Strikt genomen laat Nijboer zich hier niet uit over de toclaatbaarheid van mondeling gereproduceerde 
ook ruimte voor andersluidende conclusies. Dat is het gevolg van de onduidelijkheid die de Memorie laat bestaan over de vraag of alleen getuigenverklaringen die hun inhoud aan zichzelf ontlenen voor het bewijs mogen worden gebruikt. Zo staat daarin bijvoorbeeld geschreven:

"Evenals de verdachte mag ook de getuige alleen over door hem zelf watargenomen of ondervonden feiten of omstandigheden verklaren. De uitsluiting van het testimonium de auditu als bewijsmiddel blijft dus evenals de bepaling over eigen waarneming of ervaring en de opgave van de redenen van wetenschap gehandhaafd, zodat de uitgebreide jurisprudentie van den Hongen Raad op art. 398 W.v.Sv. toepasselijk kan blijven. Intusschen belet onk hier niets den rechter in hijzondere gevallen het behoorlijk gestaafde feit, dat een getuige een ander iets heeft hooren zeggen, roepen of verklaren, als bewijsgrond $d^{23}$ tegen de verdachte te bezigen. Practisch ligt het verschil alleen hierin, dat de rechter zoodanige bewijsgrond niet als rechtstreeksch hewijs, doch, in verband met ander bewijsmateriaal, als zogenaamde indirect bewijs moet bezigen." ${ }^{24}$

\subsubsection{Bewijsmiddelen en bewijsgronden}

In de toelichting op het oorspronkelijk regeringsontwerp werd, zoals uit bovenvermeld citaat blijkt, onderscheid gemaakt tussen bewijsmiddelen en bewijsgronden. Deze zouden zich verhouden als vorm tot inhoud ${ }^{25}$. Ten aanzien van de bewijsmiddelen is de rechter in zijn keuze beperkt; het is daarentegen geheel aan zijn oordeel overgelaten, of hij iets als bewijsgrond zal aannemen, zo blijkt uit de toelichting ${ }^{26}$. Het staat de rechter vrij, zo staat er, het feit dat iemand aan een bepaalde getuige zekere bijzonderheden omtrent het gepleegde feit meedeelde als bewijsgrond te bezigen, mits die feiten maar door wettige bewijsmiddelen tot zijn kennis zijn gebracht. In de literatuur ontstond spoedig na indiening van het oorspronkelijke regeringsontwerp discussie over dit gemaakte onderscheid tussen bewijsmiddel en bewijsgrond ${ }^{n}$.

getuigenverklaringen volgens de ontwerpers van het wetboek.

23 Cursivering door de auteur.

24 Zic MvT ORO WvSv, TK 1913-1914, 284, nr. 3, p. 170.

25 MvT ORO Wvv, TK 1913-1914, 286, nr. 3, p. 165: "Het bewijsmiddel is de trechter, waardoor het bestaan van zeker feit tot 's rechters kennis wordt gebracht. In dit feit kan echter een bewijsgrond voor het te bewijzen feit zijn gelegen. Heeft A. gezien dat B. aan C. een slag gaf, dan is de dienaangaande door $\mathrm{A}$. in den vereischten vorm afgelegde verklaring cen bewijsmiddel. De bewijsgrond voor het aannemen der aan B. telastegelegde mishandeling op C. is echter niet gelegen in het afleggen der verklaring, doch in de omstandigheid, door die verklaring bewezen, dat $\mathrm{A}$. het slaan door B. op C. heeft gezien. Bewijsmiddel en bewijsgrond zijn dus niet elkaar dekkende begrippen: zij staan tot elkander als de vorm tot den inhoud."

26 MvT ORO WvSv, TK 1913-1914, 286, nr. 3, p. 168.

27 Zie bijvoorbeeld de discussie tussen S. Gratema en Rh. Feith in het W 1914, m.n. nr. 9654, 9666, 9675 en 9684; G. Kirberger, Het bewijs in het ontwerp van Strafvordering en de motiveering van strafvonnissen, TvS 1914, p. 449 en 450. 
Men vroeg zich onder meer af, of via de grote vrijheid die de rechter gelaten wordt, zelf uit te maken wat hij als bewijsgrond wenst aan te merken, de verboden verklaring van horen zeggen niet toch door de achterdeur weer wordt binnengehaald. In dit verband is vermeldenswaard hetgeen Feith hierover opmerkte. Hij was betrokken bij de voorbereidende arbeid van de regeringsvoorstellen voor het nieuwe Wetboek van Strafvordering en antwoordde in het Weekblad van het Recht op de eerder genoemde vraag als volgt:

"De vraag is zeker van belang en hangt ten nauwste samen met de hierboven door mij aangeduide, of de wetgever er inderdaad goed aan doet de beoordeling van de bewijskracht van alle in rechte (via de wettelijke bewijsmiddelen) gebleken feiten en omstandigheden zoo geheel uit handen te geven en aan den rechter over te laten. Beantwoordt men die laatste vraag echter bevestigend, dan zie ik geen enkele reden waarom ook aan het feit, dat zekere verklaringen buiten rechte werden gedaan, in bepaalde omstandigheden geen gewicht zou mogen worden gehecht. Een doodelijk getroffene kan vó́r zijn overlijden den naam van zijn aanrander hebben genoemd. Ooggetuigen kunnen onmiddellijk na het feit aan de politie of aan particulieren mededeelingen hebben gedaan, welke zij later uit angst of om andere redenen ontkennen. Waarom zou de rechter hiermede geen rekening mogen houden? Natuurlijk zal het altijd wel tot de hooge uitzondering hlijven behooren, dat hij aan de enkele omstandigheid van het afleggen eener verklaring buiten rechte door een getuige, welke haar niet ter terechtzitting herhaalt, gewicht hecht, vooral indien die verklaring niet van elders wordt bevestigd. Doet hij zulks echter en is hij er in zoodanig geval voldoende van doordrongen, dat hij bewijskracht toekent, niet aan de verklaring zelve, doch aan het feit dat zij onder bepaalde omstandigheden werd afgelegd, dan zie ik niet in waarom hem in deze door enige verbodsbepaling de handen moeten worden gebonden. ${ }^{\text {nzo }}$

Het antwoord van Feith is tweeslachtig. Enerzijds wekt hij de indruk dat de rechter wel waarde mag hechten aan de inhoud van de verklaring van horen zeggen, anderzijds lijkt het erop dat de rechter die waarde alleen mag toekennen aan het feit dat de verklaring van horen zeggen is gedaan, dus afgezien van de inhoud ervan. Andere schrijvers wijzen er dan ook op dat het feit van het afleggen van een verklaring alleen betekenis heeft door zijn inhoud ${ }^{2}$.

Zie over dit onderscheid tussen bewijsmiddel en bewijsgrond ook: A.J. Blok en L.Ch. Besier, Het Nederlandsche Strafproces, Haarlem 1925, dl. II, p. $123 \mathrm{t} / \mathrm{m}$ 126; J.V. van Dijck, Nieuwe literatuur over een nicuw wetboek, RM 1926, p. $76 \mathrm{t} / \mathrm{m}$ 86; J.M. Reijntjes, Strafrechtelijk bewijs in wet en praktijk, Arnhem 1980, p. 128; J.F. Nijboer (1982), a.w., artt. 338-344, aant. 25, p. 50 en 51; G.J.M. Corstens (1993), a.w., p. 613.

28 Rh. Feith, De regeling van het bewijs in het ontwerp Wetboek van Strafvordering, In: W 1914, nr. 9666, Ingezonden bijdragen, p. 3 en 4.

29 Zie bijvoorbeeld G. Kirberger (1914), a.w., p. 450 en J.V. van Dijck (1926), a.w., p. 81; G.J.M. Corstens (1993), a.w., p. 613: "De vorm alleen heeft geen betekenis. Die krijgt zij pas in combinatic met de inhoud. Het feit dat een getuige iets heeft gezegd, is - afgezien van het geval dat daarmee wordt bewezen dat die getuige (nog) kan spreken - op zichzelf niet relevant. Het wordt pas interessant als we weten wat die getuige heeft gezegd." 
Naar aanleiding van deze discussie en de vragen die daarover rezen bij de Commissie van Voorbereiding gaf de minister later toe, dat de opvattingen omtrent de begrippen "bewijsmiddel" en "bewijsgrond" inderdaad aanleiding gaven tot verwarring. Hij zette in zijn antwoord nogmaals uiteen dat "het bewijs moet worden geleverd voor den rechter ter terechtzitting. De opsomming der bewijsmiddelen in het ontwerp is daarom beperkt tot de zodanige, waardoor men den rechter ter terechtzitting met redengevende feiten of omstandigheden in kennis kan brengen: alle verklaringen uit het voorbereidende onderzoek, hoewel streng genomen ook bewijsmiddelen, vallen daarmee uit. ${ }^{100}$

\subsection{Conclusie}

"Alle verklaringen uit het voorbereidend onderzoek, hoewel streng genomen ook bewijsmiddelen, vallen daamee uit. "Uit deze woorden blijkt, wat betreft het onmiddellijkheidsbeginsel, dat de makers van het wetboek met de regeling van het bewijsrecht hebben willen voorkomen, dat de rechter vonnis wijst op grond van stukken uit het vooronderzoek, voor zover daarin verklaringen van getuigen (niet zijnde bijzondere ambtenaren, zie art. 344 lid 1 sub 2 Sv) zijn opgenomen. De rechter dient de oorspronkelijke zegsman zelf te horen. Het belangrijkste doel van de wetgever was het onderzoek ter terechtzitting een mondeling en openbaar karakter te geven ${ }^{31}$. Dat het gebruik van verklaringen van horen zeggen daar op zich zelf niet mee in strijd is, vormde een complicatie, omdat men enerzijds wel besefte, dat een veroordeling op grond van verklaringen van horen zeggen wordt opgebouwd op grondslagen waarvan de betrouwbaarheid onduidelijk is, maar anderzijds deze bron van bewijs toch niet wilde prijsgeven ${ }^{32}$.

Openbaarheid, mondelinge procesbehandeling, betrouwbaarheid van bewijsmateriaal en vrije bewijswaardering; wat hebben deze aspecten met elkaar van doen? Het geheel was nog te weinig doordacht en men besloot om over adagia als 'the best evidence' niets in de wet op te nemen, maar de ontwikkeling van deze bewijsregels aan de wetenschap en de praktijk over te laten ${ }^{33}$.

30 Zie het antwoord van de minister op vragen van de Commissic van Voorbereiding, Bijlagen HTK $1917-1918$, nr. 77.1, p. 59 en 60.

31 Evenals in Duitsland, waar de verklaring de auditu ook de nodige hoofdbrekens mel zich bracht en door de wet niet expliciet is verboden. Zie hicrover mijn bijdrage: Het zwaartepunt in het strafproces, In: Schaduwen vooruit, O.r.v. G.P.M.F. Mols, Arnhem 1992, p. 1 t/m 10.

32 Zic bijvoorbeeld G. Kirberger (1914), a.w., p. $441 \mathrm{t} / \mathrm{m}$ 452, die van mening is dat alle bewijs uitcindelijk meer of minder middellijk is, en dat het enkel gaat om een deugdelijke motivering waarom de rechter het bewijs overtuigend acht. Zo cok J.V. van Dijck (1926), a.w., p. 82, die een bewijsstelsel waarbij tweede- (resp. derde-, vierde-) hands bewijs is toegelaten, onder verschillende voorbehouden wel zou durven aanvaarden.

33 Zie MvT ORO WvSv, TK 1913-1914, 286, nr. 3, p. 169: "Nu zal de rechter bij de beoordecling dier bewijsgronden ongetwijfeld ook bepaalde regelen in acht hebben te nemen. Zoo denke man aan het alleszins juiste Engelsche adagium, dat immer the best evidence aanwezig moet zijn; is 


\section{Het 'De auditu'-arrest}

Lang heeft die ontwikkeling niet op zich laten wachten. In $1926 \mathrm{nog}$, hetzelfde jaar waarin het nieuwe wetboek werd ingevoerd, werd de kwestie door de Hoge Raad beslist. In een uitspraak, die later bekend zou worden onder de naam 'De auditu'arrest ${ }^{34}$ aanvaardde ons nationaal hoogste rechtscollege als een geldige getuigenverklaring ex art. 342 lid $1 \mathrm{~Sv}$ danwel als een geldig proces-verbaal ex art. 344 lid 1 sub 2 Sv een mondelinge respectievelijk schriftelijke verklaring van een informant (overbrengende verklaring), die daarin mededeling doet van wat een ander hem ter kennis heeft gebracht (overgebrachte verklaring) ${ }^{\mathbf{3}}$.

In de betreffende zaak was een van de grieven in cassatie ${ }^{35}$ tegen het vonnis van de Rechtbank, dat dit college in strijd zou hebben gehandeld met de artt. 342 lid 1 en 344 lid 1 sub 2 Sv, doordat de Rechtbank voor het bewijs van het telastegelegde feit zou hebben gebruik gemaakt van een verklaring van horen zeggen en een proces-verbaal van een inspecteur van politie, eveneens bevattende een verklaring van horen zeggen ${ }^{37}$. Nu niet was voldaan aan het vereiste dat een getuigenverklaring en een proces-verbaal alleen behelst wat door de getuige respectievelijk de verbalisant "zelf is waargenomen of ondervonden" (zie de artt. 342 lid 1 en 344 lid 1 sub 2 Sv) zou hier geen sprake zijn van wettige bewijsmiddelen.

Advocaat-Generaal Besier was in zijn conclusie ${ }^{x s}$ van mening dat de Rechtbank de verklaringen de auditu enkel had gebruikt voor het bewijs van het feit dat deze uitlatingen waren gedaan en niet als bewijs van de inhoud van die verklaringen. Het feit dat deze uitlatingen waren gedaan achtte hij immers wel van belang voor de geloofwaardigheid van de wel voor de rechter afgelegde getuigenverklaringen. Maar hij vervolgt: "Mocht echter de Hooge Raad meenen, dat bedoeld proces-verbaal en bedoelde getuigenverklaring wel zijn gebezigd als bewijsmiddelen voor wat de daarin medegedeelde verklaringen van Es. en $F$. inhouden, dan rijst de belangrijke vraag, of dit - het voor het bewijs gebnik maken van z.g.n. verklaringen de auditu - onder de werking van het nieuwe Wetboek van Strafvordering geoorloofd is. Ik wil de gelegenheid niet laten voorbijgaan om hieromtrent mijn oordeel te kennen te geven."

het mogelijk A. zelf als getvige te doen verschijnen, dan mag de rechter zich met de verklaring van $B$., dat $A$. hem zekere mededeclingen deed, niet vergenoegen. Het schijnt echter niet gewenscht hieromtrent iets in de wet op te nemen en beter deze bewijstegelen en hunne ontwikkeling maar aan de wetenschap en de practijk over te laten."

34 HR 20 december 1926, NJ 1927, p. 85.

35 Zie J.F. Nijboer, Inleiding tot het strafrechtelijk bewijssecht (1992), a.w., p. 43 en 44.

36 Zie cassatiemiddel II, onderdeel 2 en 3.

37 Het ging hier ten aanzien van het proces-verbaal van de inspecteur van politic om een verklaring uit derde hand: de inspecteur verklaarde daarin schriftelijk wat een getuige (een vrouw) tegenover hem had verklaard omtrent wat zij van de verdachte had gehoord.

38 De conclusie van Advocaat-Generaal Besier bij deze uitspraak geeft een mooi overzicht van de discussie tussen voor- en tegenstanders van de toelating van de getuigenverklaring van horen zeggen. 
Vervolgens zet Besier uiteen waarom hij van mening is dat het Wetboek het gebruik van verklaringen de auditu voor het bewijs van het telastegelegde ontoelaatbaar acht. Daarbij knoopt hij aan bij de systematiek van de regeling en de Memorie van Toelichting. Uit het uitzonderingskarakter van verschillende bepalingen (zoals artt. 295, 341 lid 2 en 344 lid 1 sub 5 Sv) leidt hij als hoofdregel af: "dat de inhoud van niet rechtstreeks tot den rechter komende mededeelingen door dezen voor het bewijs niet mag worden gebezigd". Over de mogelijke ratio van dat verbod laat Besier zich echter niet uit.

De Hoge Raad liet zich niet leiden door het advies van zijn Advocaat-Generaal. Hij verwierp wel het betreffende onderdeel van het cassatiemiddel, maar op andere gronden dan door Besier waren aangevoerd.

\subsection{Overwegingen ten aanzien van de mondelinge getuigenverklaring van horen zeggen}

De Hoge Raad overwoog ten aanzien van de getuigenverklaring afgelegd ter zitting (art. 342 lid $1 \mathrm{~Sv}$ ), inhoudende een verklaring van horen zeggen onder meer:

"dat de Rechtbank daarbij wel voorschreven voorbehoud heeft gemaakt, daarmee kennelijk bedoelende dat die verklaring van getuige Eis. enkel is gebezigd als bewijs van het feit der uitlating, doch de wet zulk een voorbehoud niet kent en daarmee niet kan worden bereikt (..) dat de gewraakte getuigenverklaring niet heeft gediend tot het bewijs der telastelegging;"

"dat van strijd met art. 342 Sv geen sprake kan zijn, daar bedoelde verkJaring den gehoorsindruk van de getuige weergeeft, dus loopt over een door die getuige zelf waargenomen feit, nl, dat aan haar de gerelateerde mededeling is gedaan, terwijl de wet omtrent het gebruik, dat de rechter van dit wettig bewijsmiddel (bedoelde getuigenverklaring) mag maken bij de constructie van het bewijs, te weten omtrent de kracht der aanwijzing liggende in het feit, dat die mededeeling is gedaan, geen enkel voorschrift bevat, zodat de wet den rechter geenszins dwong om het door hem als vaststaande aangenomen feit der mededeeling bij de vorming van zijn oordeel over hetgeen als bewezen kan worden aangenomen en de constructie van het bewijs, terzijde te laten;"

"dat mitsdien het systeem der wet, al evenmin als een bepaald wetsartikel, tot het aannemen van bedoeld verbod (om een verklaring van horen zeggen voor het bewijs te gebruiken) ${ }^{*}$ kan leiden;"

"dat de uitsluiting van het testimonium de auditu ook zou zijn tegen de geest van het nieuwe wetboek, waaraan de gedachte ten grondslag ligt om enerzijds den rechter tot een deugdelijke motivering van zijn vonnis te verplichten en anderzijds geen enkele bron gesloten te houden, waaruit de rechter licht zou kunnen putten; - dat daardoor ook de waarheid der vonnissen wordt gediend, omdat de rechter nu niet genoodzaakt is om getuigenverklaringen, ook indien deze zonder eenigen twijfel tot het vestigen van zijn overtuiging hebben bijgedragen, bij de schriftelijke opstelling van de gronden zijner beslissing, achterwege te laten;"

Cursief geschrevene is toegevoegd door de auteur. 
"dat eenerzijds niet valt te ontkennen, dat verklaringen van hooren zeggen in veel gevallen slechts van zeer betrekkelijke waarde zullen zijn en dus met de uiterste behoedzaamheid moeten worden beschouwd, waarbij de rechter zich er steeds nauwkeurig rekenschap van heeft te geven, waartoe bij zulke getuigenissen de inhoud der eigen waarneming van den getuige is beperkt, doch anderzijds niet is in te zien, waarom de rechter met dergelijke verklaringen in het geheel geen rekening zou mogen houden, te minder omdat, ook waar het andere dan de hier bedoelde verklaringen betreft, de rechter doorloopend tot taak heeft de waarde van het hem voorgelegde bewijsmateriaal niet anders dan met de uiterste zorg en zorgvuldigheid na te gaan;"

\subsection{Overwegingen ten aanzien van de schriftelijke getuigenverklaring van horen zeggen}

Ten aanzien van het gebruik van het proces-verbaal (art. 344 lid 1 sub 2 Sv) inhoudende een verklaring van horen zeggen, overwoog de Hoge Raad onder meer:

"dat hier geen aanleiding bestaat voor het aanvoeren van een bijzondere grief betreffende het gebruik van een opgave van de verdachte, daar de Rechtbank als wettig bewijsmiddel heeft gebruikt en mocht gebruiken de verklaring van den verbalisant Van Oerle omtrent hetgeen deze zelf heeft waargenomen, te weten de door E Es. gedane medeedeling fover wat de verdachte haar had verteld $)^{40}$, terwijl de rechter nergens wordt beperkt in het gebruik, dat hij van het door hem als vaststaande aangenomen feit der mededeeling voor het bewijs der telastelegging meent te moeten maken;"

\section{Achtergronden van het 'De auditu'-arrest}

Het Wetboek van Strafvordering van 1838 stelde aan het bewijsmiddel "getuigenis" de eis, dat deze moest "loopen over feiten welke de getuige zelf gehoord, gezien of ondervonden hecft" (art. $398 \mathrm{~Sv}$ ). In de rechtspraak werd toen de opvatting gehuldigd dat deze formulering in de weg stond aan het gebruik van het testimonium de auditu als bewijsmiddel. Over het algemeen werden verklaringen van getuigen die daarin mededeling deden van wat anderen aan hen hadden medegedeeld, als ontoelaatbaar beschouwd. Op deze regel bestonden echter wel door de jurisprudentie toegelaten uitzonderingen ${ }^{4 t}$. Zo was bijvoorbeeld de zogenoemde 'cri de justice', een kreet

40 Cursief geschrevene is toegevoegd door de auteur.

41 Zie A.J. Blok en L.Ch. Besier, a.w., deel II, p. 146 I/m 148; I.A. Nederburgh, Hoofdstukken over strafvordering voor Nedederlandsch Indiē, decl II: Het Bewijs, 's Gravenhage 1911, p. 141 e.v.; B.M. Taverne, Art. 398 van het Wetbock van Strafvordering, MRT 1909, p. 116 e.v.. Zie ook Léon's Rechtspraak, Deel Il, afl. 6, Wetbock van strafvordering; rechtspraak, literatuur en korte aantekeningen, tweede gedeelte - (art. 258-398), Leiden 1935, 4c druk, p. 1004 en 1005; G.J.M. Corstens, Van Cri de justice naar anonieme getuigenverklaring: 75 jaar de-auditu-jurisprudentic, In: NJ 19131988, Annotatoren kijken terug, Zwolle 1988, p. 34 1/m 44. 
van schrik of verontwaardiging van horen zeggen voor het bewijs wi: toelaatbaar. Men vatte een dergelijke uitlating op als een 'reflex', en daarom als hetrouwbaar'. Gezien deze constante jurisprudentie wekt het verbazing dat d' Hoge Raad zo kort na de inwerkingtreding van het nieuwe Wetboek van Strafvordering overstag ging, zeker nu op dit punt geen wezenlijke verandering van wetgeving had plaatsgevonden. Ook het nieuwe art. 342 lid 1 Sv stelde aan het bewijsmiddel van de getuigenverklaring de eis dat deze moet inhouden een mededeling over feiten en omstandigheden. door de getuige "zelf waargenomen of ondervonden". Hoe is die plotseling kuerswijziging te verklaren?

\subsection{De opvattingen van Taverne over de verklaring van horen zeggen}

In het 'De auditu'-arrest van de Hoge Raad is duidelijk de opvatting te herkennen van Taverne ${ }^{43}$, die zelf deel uitmaakte van het college dat in deze zaak uitspraak deed. Taverne was ten tijde dat het oude wetboek nog het geldende recht vormde, reeds een tegenstander van de oude leer van de Hoge Raad, zoals onder meer blijkt uit zijn opstel over art. $398 \mathrm{~Sv}$ in het Militair Rechtelijk Tijdschrift van 1909. Ook na de inwerkingtreding van het nieuwe wethoek in 1926 zet hij zijn oppositie voort ${ }^{4}$.

\subsubsection{Gehoorsindruk is zelf warargenomen of ondervonden}

De kritiek van Taverne tegen de door de Hoge Raad aangehangen leer komt er in het kort op neer dat volgens hem noch de wettelijke tekst vian art. $398 \mathrm{~Sv}$ (oud), noch die van art. $342 \mathrm{~Sv}$ de rechter verbiedt om een verklaring van horen zeggen voor het bewijs te gebruiken. Immers, dat wat een getuige van een derde heeft gehoord, vormt een zuivere gehoorsindruk, die door de getuige "zclf is waargenomen of ondervonden".

Wat overigens opvalt bij de hele discussie rond de toelaatbaarheid van de getuigenverklaring van horen zeggen, is het legistische karakter van de argumentatie ${ }^{45}$.

42 Zic bijvoorbeeld HR 12 april 1898, W 7117; HR 19 mei 1913, NJ 1913, 1018; HR 14 juni 1920, W 10592; NJ 1920, 747.

43 Zie over de persoon Taverne: J.F. Nijboer, 'B.M. Tavernc: onbescheiden magistraat', D\&D 1985, p. $716 \mathrm{t} / \mathrm{m} 731$.

44 Zic B.M. Taverne, Het testimonium de auditu, TvS 1926, p. $115 \mathrm{t} / \mathrm{m} 146$.

45 Zie bijvoorbeeld D. Simons, Getuigenis van horen zeggen, W 1927, nr. 11604; A.J. Blok en L.Ch. Besier, Het Nederlandsche strafproces, Haarlem 1925, p. $143 \mathrm{I} / \mathrm{m}$ 148; Conclusic van AdvocaatGeneraal Besier bij HR 20 december 1926, NJ 1927, 85; J.V. van Dijck, Nieuwe literatuur over een nicuw wetboek, RM 1926, p. 85; B.M. Taverne, Art. 398 van het Wetbock van Strafvordering. MRT 1909, p. 116 e.v.; B.M. Taverne, Het Testimonium de auditu, TvS 1926, p. 115 1/m 146; J.V. van Dijck, Het de auditu-arrest, NJB 1927, p. 49t/m 54; R. Bromberg. Nogmaals "het testimonium de auditu", NJB 1928, p. 269 1/m 274; J.V. van Dijck, Nog, eens het de auditu-arrest, NJB 1928, 
Men zoekt aansluiting bij de woordkeuze van de wettekst en het systeem van de wettelijke regeling, maar vraagt zich nauwelijks af wat de ratio zou kunnen zijn van een verbod de verklaring de auditu te gebruiken voor het bewijs. Deze benadering past bij haar tijd waarin de wet als enige bron van recht werd erkend ${ }^{\text {th }}$. Ook Taverne wijkt nauwelijks af van die benadering, behalve wanneer hij schrijt:

"Alle argumenten, welke men voor het weren van de testimonia de auditu kan horen, te weten dat de personen, wiens uitingen worden medegedeeld niet beëedigd zijn (hetgeen echter onder de nieuwe wet heel wat minder zegt dan onder de oude), dat de rechter de personen niet zelf ziet, dat over den inhoud der mededeeling, te weten de juistheid daarvan, niet gedebatteerd kan worden ${ }^{n}$, dat ongeoorloofd getuigen-materiaal wordt binnengesmokkeld, kunnen van betekenis zijn voor de vraag, of de wet den rechter moet verbieden van zulke verklaringen gebruik te maken, zij kunnen m.i. nooit de gehoorswaarmeming van den getuige maken tot iets dat hij niet zelf heeft gehoord of waargenomen.

Taverne heeft er kennelijk oog voor, dat de onmogelijkheid om tot een juiste beoordeling te kunnen komen van de bewijskracht van de overgebrachte verklaring, als niet de oorspronkelijk zegsman ter zitting verschijnt om te kunnen worden geobserveerd en ondervraagd en om te kunnen worden geconfronteerd met ander bewijs en de verdediging, een valabel argument vormt tegen het gebruik van de verklaring van horen zeggen voor het bewijs. Maar na deze opmerking van meer inhoudelijke aard, gaat ook Taverne weer verder op de legistische weg. Hij vervolgt:

"Het is (..) bij ons de wetgever en niet de rechter, die heeft te overwegen, of de hiervoren aangehaalde vermaning (..) tot verbod of beperking ten aanzien der de auditu's, ook waar het den beroepsrechter betreft, moet leiden. (..) En nog eens, de wet bevat nu eenmaal dat verbod niet, mits de getuige de gedane mededeeling maar zelf, met zijn eigen ooren, heeft gehoord en zich niet bepaalt tot de verklaring dat een zekere gebeurtenis heeft plaats gegrepen, terwijl hij die gebeurtenis niet zelf heeft waargenomen, doch zij den inhoud vormt eener hem gedane mededeeling; een zeer groot verschil." ${ }^{\text {m9 }}$

p. 309 t/m 313; R. Bromberg, Het "de-auditu-arrest", NJB 1928, p. 350 en 351 . Zie over deze discussie ook J.F. Nijboer, Algemene grondslagen van de bewijsbeslissing in het Nederlandse strafprocesrecht, Arnhem 1982, art. 338, aant. 17, p. 31 t/m 39.

46 Zie W.PJ. Pompe, Geschiedenis der Nederlandsche Rechtswetenschap, Deel II, Afl. III, Amsterdam 1956, Inleiding, p. 226 en 227.

47 Cursivering door de auteur.

48 B.M. Taverne (1926), a.w., p. 119.

49 B.M. Taverne (1926), p. 120. 
Dat Taverne toch weer aansluiting zockt bij een grammaticale wetsuitleg heeft mijns inziens echter nog een andere reden dan de wens om vast te houden aan de strikte scheiding der machten. De woorden van de wettekst boden hem immers de ruimte voor zijn opvatting dat verklaringen van horen zeggen voor het bewijs gebruikt moeten kunnen worden. Die opvatting werd hem echter niet zozeer ingegeven dour de wettekst, maar door zijn ervaring dat, ook al zou je de rechter verbieden voor het bewijs gebruik te maken van verklaringen van horen zeggen, de rechter dit toch altijd zal blijven doen. Hij kan niet anders. Een verbod van het gebruik van de auditu verklaringen gaat volgens Taverne uit van de fictie dat de rechter bij zijn oordeelsvorming bepaalde elementen kan uitsluiten, terwijl hij ze wel kent: "Eris slechtséén volkomen eerlijke methode. Men snoere den getuige of verdachte den mond zodra hij iets wil gaan mededeelen, dat hij een ander he'ft hooren zeggen of zoodra hij iets over zijn medeverdachte wil zeggen, ook in het voor-onderzoek. De rechtermoet w'el aan de w't voldoen, hem treft geen blaam, maar ieder psycholoog w'et dat hij bij het vomen van zijn ol'rrtuiging niet een bepaalde verklaring of mededeclingen wan den modev'orduchte he'ft kumnen uitschakelen. Alleen de vrijheid van den rechter kan hier uitkomst geven. ${ }^{150}$ Het zal de eerlijkheid van de rechterlijke beslissing en motivering ten goede komen, aldus de schrijver.

Taverne moet van mening zijn geweest dat deze feitelijke onmogelijkheid van een verbod van het gebruik van verklaringen van horen zeggen voor het bewijs aan het argument van de controleerbaarheid van het bewijsmateriaal alle kracht ontzegt.

\subsection{Conclusie}

Het feit dat Taverne zelf deel uitmaakte van het hoogste rechtscollege dat verantwoordelijk was voor het 'De auditu'-arrest, naast de omstandigheid dat de wetgever geen duidelijkheid verschafte ten aanzien van de toelaathaarheid van de getuigenis van horen zeggen en het bestaande gebrek aan inzicht in de relatie tussen openbaarheid, mondelinge procesbehandeling, hetrouwbaarheid van bewijsmateriaal en bewijswaardering, biedt een plausibele verklaring voor de omstandigheid dat de Hoge Raad 'om' ging, zo kort na het in werking treden van het nieuwe wetboek.

\section{De betekenis van het negatief wettelijke bewijsstelsel}

De bovengenoemde opvatting van Taverne over het gebruik van verklaringen van horen zeggen voor het bewijs past uitstekend in zijn visie over de jurist en diens

50 B.M. Taverne, Een nicuw de-audilu-arrest, NJB 1928, p. 446. 

uit:

"De jurist is van ouds zoo verzot op ficties, dat hij er bijna niet buiten kan." (..) "Het is mijns inziens de dure plicht van ieder die voelt voor de waarachtigheid en het vertrouwen der rechtspraak om den strijd tegen de ficties aan te binden. $\mathrm{Zij}$ ondergraven de fundamenten van het gebouw van waarheid en recht, waarop alle rechtspraak moet steunen. Men onderschatte het gevaar niet. De ficties verduisteren het inzicht in de werkelijkheid." (.) "Over de groote fictie, de overtuiging "door den inhoud van wettige bewijsmiddelen" zal ik thans maar zwijgen. Ik haal aan, wat ik wel eens meer heb aangehaald: "Il n'y a pas de loi qui puisse règler ou commander la certitude". Als de wettenopstellers toch eens wilden beseffen, dat zij door dergelijke voorschriften niets bereiken, ja alleen verhinderen dat de rechterlijke uitspraken van kunstige gebouwtjes met kronkelige versieringen worden tot monumentale zuilen van naakte waarheid."

Met andere woorden, bron van alle uitspraken van Taverne over het gebruik van verklaringen van horen zeggen voor het bewijs was zijn ongeloof in de waarde van het negatief wettelijke bewijsstelsel dat aan ons Wetboek van Strafvordering ten grondslag ligt. Het is in het kader van de achtergronden van het 'De auditu'-arrest, maar ook met het oog op vragen rond het onmiddellijkheidsbeginsel de moeite waard om iets dieper op het functioneren van dit bewijsstelsel in te gaan.

\subsection{Het negatief wettelijke bewijsstelsel}

Het negatief wettelijke bewijsstelsel staat tegenover het positief wettelijke en de vrije bewijsstelsels. Deze in de literatuur gemaakte indeling is gebaseerd op de mate waarin en de manier waarop de beslisser door wettelijke regels bij zijn beslissing is beperkt: enerzijds in de keuze van zijn bronnen, anderzijds in de waardering van hetgeen uit die bronnen mag worden afgeleid ${ }^{52}$.

$\mathrm{Bij}$ de vrije bewijsstelsels staat het de beslisser vrij om al het beschikbare bewijsmateriaal aan zijn beslissing ten grondslag te leggen. Hij is hierbij, evenals bij de waardering daarvan alleen gebonden aan algemene verstandelijke maatstaven, waarvan zijn overtuiging doorgaans als enig beslissend criterium is aangegeven.

$\mathrm{Bij}$ de wettelijke bewijsstelsels mag de beslisser zijn oordeel alleen baseren op die bewijsmiddelen die door de wet zijn aangewezen. Bij gebrek aan een bepaalde

51 HR 23 mei 1921, NJ 1921, 564.

52 Zie J.F. Nijboer, Inleiding tot het strafrechtlijk bewijsrecht, Nijmegen 1992, vierde druk, p. 23 en 24. Zie ook de aanvulling die Nijboer op deze traditionele indeling maakt: "Een didaktisch handzame aanduiding voor het Nederlandse bewijsstelsel is (..) dat het deels negatief-wettelijk, deels negatief jurisprudentieel is." Zie p. 31. Zie ook J.F. Nijboer, Algemene grondslagen van de bewijsbeslissing in het Nederlandse strafprocesrecht, Arnhem 1982, artt. 338-344, aant. $28 \mathrm{t} / \mathrm{m}$ 34, p. $53 \mathrm{t} / \mathrm{m} 62$. 
hoeveelheid door de wet erkende bewijsmiddelen is de beslisser gedwongen de verdachte vrij te spreken. Bij aanwezigheid van een bepaalde hoeveelheid wettige bewijsmiddelen verplichten de positief wettelijke bewijsstelsels de beslisser tot veroordeling over te gaan, terwijl de negatief wettelijke de beslisser verbiedt tot veroordeling over te gaan, indien deze niet tevens overtuigd is dat de verdachte het feit waarvan hij wordt beschuldigd, heeft begaan. Hieruit volgt dat in de positief wettelijke stelsels de bewijskracht van de wettelijke bewijsmiddelen door de wet wordt bepaald, terwijl in de negatief wettelijke stelsels de bewijskrachtbepaling aan de beslisser zelf wordt overgelaten (vrije bewijswaardering) ${ }^{\text {si }}$.

Het Nederlandse strafprocesrecht kent vanaf 1838 ononderbroken een negatief wettelijke bewijsregeling. Het Wetboek van Strafvordering beperkt de rechter in zijn keuze van bewijsmiddelen waarop hij zijn overtuiging mag baseren. Deze bewijsmiddelen zijn limitatief opgesomd in de wet (art. $339 \mathrm{~Sv}$ ). Uit de Memorie van Toelichting is af te leiden dat de wetgever van mening was dat deze bewijsmiddelen uit hun aard reeds een zekere betrouwbaarheid bezitten ${ }^{\text {s. }}$. Waaraan zij deze kwalificatie ontlenen, liet de wetgever helaas onbesproken. Pols, die gezien kan worden als een van de grootste aanhangers van de negatief wettelijke bewijsleer uit het eind van de vorige eeuw, verbindt deze kwalificatie aan de mate van onmiddellijkheid tussen de rechter en de te bewijzen feiten. Hij schrijft: "(.) het behoeft wel geen betoog dat de zekerheid onzer kennis vermindert, naarmate wij zelve verder van de bron der zinnelijke waameming verwijderd zijn, meerdere intermediairen moeten gebruiken; omdat ieder nieuw intermediair ook een nieuwe bron van dwaling opent en een afzonderlijk onderzoek van de zuiverheid der verkregen kennis vordert. ${ }^{\text {"ss }}$ Bewijsmiddelen die de inhoud aan zichzelf ontlenen, zijn betrouwbaarder dan andere bewijsmiddelen omdat de kans op vertekening van de informatie daarbij kleiner is.

Vanaf het midden van de vorige eeuw ontspon zich in de literatuur een uitgebreide discussie over de wenselijkheid van het behoud en de inhoud van de wettelijke bewijsregeling ${ }^{56}$. Die discussie kwam voort uit de onvrede met de gebrekkige wijze waarop het negatief bewijsstelsel was vormgegeven in het Wetboek van Strafvordering van

53 Zie ook MvT ORO WvSv, TK 1913-1914, 286, nr. 3, p. 162 en 163 en M.S. Pols, De wettelijke bewijsleer in strafzaken, RM Themis 1882 , p. 373.

54 Zic MvT ORO WvSv, TK 1913-1914, 286, nr. 3, p. 164: "Eene opsomming der bewijsmiddelen is nodig om te voorkomen, dat de rechter (..) op bewijsmiddelen, wier betrouwbaarheid reeds door hun oorsprong wordt uitgesloten, zal recht doen."

55 M.S. Pols (1882), a.w., p. 372.

56 Zie hierover J.F. Nijboer, Naar een vrije bewijsregeling?, D\&D 1982, p. 187 1/m 191. Illustratief zijn ook de beraadslagingen gevoerd in de Nederlandse Juristenvereniging naar aanleiding van de vraag: 'Is wijziging van de regelen voor het bewijs in strafzaken wenschelijk? Zoo ja, in hoeverre moet het wettelijk bewijs worden behouden?', Hand. NJV 1882. Tweede decl, Den Haag 1882, p. $143 \mathrm{t} / \mathrm{m} 234$. Zie ook de beraadslagingen naar aanleiding van het preadvies van $R$. Feith over het bewijs in strafzaken, Hand. NJV 1910, Den Haag 1910, deel I, p. 1 t/m 95 en deel II, p. 107 $1 / \mathrm{m} 220$. 
$1838^{57}$. Het is hier niet de plaats om deze discussie in detail uiteen te zetten. Ik beperk me tot het hoofdargument ${ }^{\text {s" }}$ dat door de tegenstanders van de negatief wettelijke bewijsleer werd gebruikt.

\subsection{De innerlijke tegenstrijdigheid van het negatief wettelijke bewijsstelsel}

De tegenstanders van de negatief wettelijke bewijsleer waren van mening dat door de wetenschap en ervaring weliswaar bewijsregels zijn voortgebracht, maar dat deze bewijsregels geen absolute geldigheid bezitten en daarom niet altijd toepasselijk zijn. De wet kan die regels niet verbindend verklaren zonder in vele gevallen de vrije vorming van de rechterlijke overtuiging te belemmeren door regels die in het concrete geval zuiver formeel of fictief zijn"s. De verwachting dat onmiddellijk bewijs ook steeds het meest betrouwbare bewijs oplevert, gaat niet altijd op. Een verklaring van een getuige die daarin mededeling doet van wat de verdachte hem vertelde, kan onder omstandigheden een betrouwbaarder beeld van de feiten geven dan de eigen verklaring van de verdachte afgelegd ter zitting.

Toegegeven moet worden dat niet kan worden volgehouden dat gereproduceerd bewijs per definitie minder betrouwbaar is dan origineel bewijs. Pols wijst zijn opponenten er echter op dat dit er niet aan af doet, dat de kans op vertekening van de betreffende informatie groter is naar mate die informatie over meer schakels tot de rechter komt. De negatief wettelijke bewijsleer gaat ervan uit dat de kans op onjuiste rechterlijke beslissingen zo klein mogelijk moet zijn. Daarom eist deze leer dat de rechter alleen dan tot veroordeling overgaat indien hij tot de overtuiging is gekomen dat de verdachte het strafbare feit heeft begaan op grond van wettige (onmiddellijke) bewijsmiddelen. De negatief wettelijke bewijsleer beperkt de rechter niet in zijn bewijswaardering, het beperkt de rechter in zijn keuze van wat hij als bewijsmiddel mag aanmerken. De vrije bewijswaardering van de rechter is daarmee beperkt tot die bewijsmiddelen die aan de wettelijke omschrijvingen voldoen ${ }^{60}$.

Dit verweer van Pols zou in de ogen van Damaška niet overtuigend zijn . Hij schrijft in dit verband:

"Rules excluding hearsay could have appeared to reformers as an acceptable solution because, as a theoretical matter, they do not interfere with the factfinder's freedom in evaluating evidence. Viewed analytically, the rules only shrink the pool of information available to factfinders, and do not compel them to process admissible information in a designated way. At a deeper level, however, rules that exclude hearsiy create a tension with the premise

M.S. Pols (1882), a.w., p. 355. Zie in dit verband ook W. Modderman, De wettelijke bewijsleer in strafzaken, Utrecht 1867 , p. 170 en 218 e.v. 
that the probative force of evidence eludes regulation by binding legal rules. If the evidence's validity is indeed so heavily dependent on context that regulators cannot make adequate advance assessments of its reliability, then all admissibility rules that express a negative ex ante judgment about the value of second-hand information (that is, all relevance based admissibility rules), are equally spurious. Under some circumstances, hearsay could be more reliable than direct oral testimony. ${ }^{\mathrm{nhi}}$

Volgens Damaška leidt de negatief wettelijke bewijsleer aldus aan een innerlijke tegenstrijdigheid. De beperking van de rechter in zijn keuze van de bewijsmiddelen die hij voor zijn oordeel mag gebruiken staat op gespannen voet met het in die leer gelijkertijd gehuldigde uitgangspunt van de vrije bewijswaardering ${ }^{\alpha 2}$. Dit uitgangspunt gaat er nu juist van uit dat de wetgever vooraf geen geldige uitspraken kan doen over de bewijskracht van bewijsmiddelen in een concreet geval, ook niet over het gebrek aan bewijskracht. Damaška is dan ook van mening dat voor een categoriale uitsluiting van gereproduceerd bewijs geen rechtvaardiging is te vinden in de gepretendeerde grotere betrouwbaarheid van originele bewijsmiddelen maar hoogstens in de wens om de verdachte tegen de macht van de overheid te beschermen ${ }^{a}$.

I $k$ ben het met Damaška eens dat het criterium van de betrouwbaarheid op zich zelf geen juiste maatstaf biedt voor de vraag naar de toelaatbaarheid van gereproduceerde vormen van bewijs voor het oordeel van de rechter. Of de informatie die in originele of gereproduceerde vorm tot kennis van de rechter komt, overeenstemt met hetgeen in werkelijkheid is geschied, zal nooit meer met absolute zekerheid kunnen worden vastgesteld. Of een originele verklaring danwel de verklaring van horen zeggen meer geloof verdient, kan zonder context niet worden beantwoord.

Het is die context waarom het gaat. De bewijskracht van een bewijsmiddel is alleen te bepalen wanneer dit in zijn context kan worden geplaatst. Het probleem bij gereproduceerde vormen van bewijs is dat de context daarvan aan duidelijkheid te wensen overlaat. Heeft de oorspronkelijke zegsman wel verklaard hetgeen gezegd wordt? Heeft de oorspronkelijke zegsman wel bedoeld hetgeen gezegd wordt? Heeft de oorspronkelijke zegsman wel kunnen zien hetgeen hij volgens de overgebrachte verklaring zou hebben gezien? Hoe dient de rechter de tegenstrijdigheid te waarderen tussen hetgeen de oorspronkelijke zegsman zou hebben verklaard en hetgeen de verdachte ter verdediging aanbrengt?, enzovoorts, enzovoorts. De rechter krijgt geen antwoord op vragen waarvan de beantwoording essentieel is voor een juiste waardering van de overgebrachte informatie. Dat maakt de waardering van de overgebrachte informatie zonder de oorspronkelijke bron daarvan gezien en gehoord te hebben tot een min of meer ${ }^{* 4}$ willekeurige aangelegenheid. Van de rechter wordt echter

61 Mirjan Damaška, Of hearsay and Its Analogues, Minnesota Law Review 1992, vol. 76, p. 445.

62 Zie hierover ook J.F. Nijboer, Inleiding tot het strafrechtelijk bewijsrecht (1992), a.w., p. 49.

63 Mirjan Damaška (1992), a.w., p. 445.

64 Afhankelijk van de aard van de informatic en de wijze: van reproduktic. Zie hoofdstuk $2, \$ 4.3 .2 .1$. e.v. 
alles behalve een willekeurig oordeel gevraagd. Daarvoor zijn de belangen die op het spel staan te groot. De zekerheid die van de rechter wordt gevraagd, komt tot uitdrukking in het adagium 'in dubio pro reo'. De rechter die geen antwoord kan krijgen op vragen die van essentieel helang zijn voor de juiste waardering van het voor handen zijnde bewijsmateriaal (context), dient de verdachte het voordeel van de twijfel te gunnen en om die reden dat betreffende bewijs als onbruikbaar te bestempelen om daarop een veroordeling te baseren. Het argument voor de uitsluiting van gereproduceerde vormen van bewijs van het gebruik als basis van een veroordeling moet niet gezocht worden in de (on)betrouwbaarheid van dit bewijs. Daarover kunnen immers op voorhand geen uitspraken worden gedaan. De reden waarom gereproduceerde vormen van bewijs als veroordelingsbasis gediskwalificeerd dienen te worden, is gelegen in de beperkte mogelijkheid voor de rechter dit bewijs in een contradictoire 'setting' op zijn kwaliteit en betrouwbaarheid te controleren. Daarover kunnen op voorhand wel uitspraken worden gedaan. Wanneer de rechter de oorspronkelijke bronnen van bewijs zelf ziet, heeft hij drie controle-mogelijkheden die gemist worden bij het gebruik van gereproduceerd bewijs: de eigen indruk, de gelegenheid om vragen te stellen en de confrontatie met ander bewijs en/of de verdediging ${ }^{\text {nt }}$.

\subsection{Praktische onmogelijkheid van het negatief wettelijke bewijsstelsel}

In art. $338 \mathrm{~Sv}$ komt de keuze voor de negatief wettelijke bewijsleer tot uitdrukking Deze bepaling schrijft voor dat de rechter zijn overtuiging dient te baseren op wettige bewijsmiddelen. Volgens Taverne vraagt de wet daarmee van de rechter het onmogelijke. Hoe kan men van de rechter verlangen dat hij verklaringen van horen zeggen niet laat meewerken tot zijn overtuiging, terwijl hij daarmee op de zitting wel geconfronteerd wordt? In werkelijkheid werkt de verboden informatie toch mee aan de overtuiging van de rechter. Alleen vind je daarvan geen bewijzen terug in het vonnis. De praktijk is immers, aldus Taverne, dat de rechter in gedachte of op papier een goed gemotiveerd en overtuigend vonnis maakt. Daarbij betrekt hij ook de ter terechtzitting nu eenmaal niet tegen te houden verklaringen van horen zeggen. Pas daarna schrapt de rechter al deze 'testimonia de auditu' omdat hij deze volgens de wet niet mag gebruiken. Het resultaat is dat het vonnis als los zand aan elkaar komt te hangen en voor de niet-ingewijde niet meer is te lezen, aldus deze schrijver ${ }^{r 7}$.

6ó Aldus de MvT ORO WvSv, TK 1913-1914, 286, nr. 3, p. 167.

67 B.M. Taverne (1928), a.w., p. 447. 
Taverne gaat er blijkbaar vanuit dat rechters in werkelijkheid hun overtuiging primair stellen en vervolgens eerst op zoek gaan naar eventuele wettelijke bewijsmiddelen voor die overtuiging ${ }^{\text {s. }}$.

Die mening wordt gedeeld door anderen zoals bijvoorbeeld blijkt uit het boek 'Dubieuze Zaken' van Crombag, Van Koppen en Wagenaar. Volgens hun 'theorie van verhaal en verankering' is de kwaliteit van het verhaal ${ }^{\infty \phi}$ het uitgangspunt voor de bewijsbeslissing van de rechter. Het verschil tussen hun theorie en de klassieke benadering, die inhoudt dat rechters van feiten naar conclusies redeneren, is volgens de schrijvers gelegen in de rol die men daarbij aan de bewijsmiddelen toekent. In de traditionele zienswijze zijn de bewijsmiddelen primair, het verhaal wordt daaruit opgebouwd. In de 'theorie van verhaal en verankering' is het verhaal primair en zijn de bewijsmiddelen alleen controlepunten. De schrijvers denken dat de rechter niet anders kan dan het verhaal als uitgangspunt te nemen voor de bewijsbeslissing en de toetsing van het verhaal aan de feiten daarop te laten volgen. Als een zaak zonder verhaal zou moeten beginnen, zou het volgens hen bijvoorbeeld niet mogelijk zijn om onderscheid te maken tussen verdachten en getuigen. Iedere strafzaak begint nu eenmaal met een verdachte en dus met een verhaal over het strafbare feit dat die verdachte zou hebben gepleegd. Vanaf dat moment is er een verhaal - goed of slecht, rudimentair of uitvoerig - dat door de rechter op de een of andere wijze getoetst moet worden ${ }^{70}$. Deze schrijvers achten de door hun theorie beschreven redeneertrant de enig mogelijke oplossing voor de problemen waarvoor de strafrechter zich ziet geplaatst. Waar zij kritiek op hebben is dat de strafwetgeving, de inrichting van het strafproces en de jurisprudentie net doen alsof de rechter géén gebruik maakt van deze redeneerwijze. Het officiële standpunt lijkt nog steeds te zijn dat de rechter redeneert van feiten naar cunclusies".

Wat in de opvatting van Crombag, Van Koppen en Wagenaar meespeelt is dat de rechter niet alleen ter zitting geconfronteerd wordt met informatie die hij bij zijn beslissing buiten beschouwing dient te laten, maar ook dat de rechter in ons

$68 \mathrm{Zic}$ in dit verband ook Ch.J. Enschedé, Bewijzen in het slrafrecht, R.M. Themis 1966, p. 515 over hetgeen hij opmerkt ten aanzien van het weltclijke verbod de verklaring van een mede-verdachte voor het bewijs te gebruiken (art. 341 lid 3 Sv); "(..) zo'n bepaling kan niet verhinderen, dat 's rechters overtuiging omtrent de schuld van $A$ tot stand komt onder invloed van B's verklaring. Het effect van het voorschrift is slechts, dat die invloed, indien aanwezig, nict in de motivering weerspiegeld kan worden, en overigens geeft het slechts aanleiding tot zinloze clauses de style."

69 "Dat verhaal is om te beginnen het verhaal dat het openbaar ministerie presentecrt in de vorm van de tenlastelegging en het dossier waarop die gebaseerd is. Tijdens de bchandeling van de zaak bereikt het verhaal allengs de uiteindelijke vorm waarop de beslissing van de rechtbank of het hof wordt gebaseerd. Die uiteindelijke vorm wordı bepaald door de bijdragen van drie partijen: het openbaar ministerie, de verdediging en de rechter zelf." Zie H.F.M. Crombag, P.J. van Koppen en W.A. Wagenaar, Dubieuze zaken; de psychologie van strafrechtclijk bewijs, Amsterdam 1992, p. 446.

70 H.F.M. Crombag e.a. (1992), a.w., p. 446 en 447.

71 H.F.M. Crombag c.a. (1992), a.w., p. 458. 
strafproces voorafgaand aan de terechtzitting kennis neemt van alle processtukken. Ook op grond van deze kennisneming zou de rechter reeds komen tot een zekere overtuiging omtrent het gepleegd zijn van de telastegelegde feiten, of - in het jargon van Crombag c.s. - tot een eigen verhaal van het gebeuren.

Ik denk dat deze laatste bewering moeilijk valt tegen te spreken. Maar, het is de vraag of dat in strijd is met de negatief wettelijke bewijsleer. Dat de rechter het verhaal uit de stukken van het vooronderzoek tot uitgangspunt van zijn onderzoek ter zitting neemt, is niet alleen onvermijdelijk, dat is ook steeds de bedoeling geweest. Het onderzoek ter terechtzitting is nooit bedoeld geweest als een onderzoek waaraan nog niets is voorafgegaan. Het vooronderzoek dient de rechter in staat te stellen zijn onderzoek ter terechtzitting zodanig in te richten dat hij de van hem verlangde beslissing in beginsel op grond van één onafgebroken zitting kan nemen. Daarvoor is kennisneming van de stukken uit het vooronderzoek noodzakelijk. Hierdoor krijgt de rechter inzicht in de belangrijkste bewijsmiddelen die de officier van justitie aandraagt ter staving van de telastelegging. Zo weet de rechter waar in de controle van deze informatie de nadruk moet liggen. Van de rechter valt wel onbevangenheid te eisen, maar niet door hem in het onderzoek de voor een behoorlijke vervulling van zijn functie instrumenteel te hanteren kennis te onthouden ${ }^{72}$. Van hem kan en mag alleen worden geëist dat hij kritisch blijft ten aanzien van de overtuiging waartoe hij op basis van bestudering van de stukken zou zijn gekomen, zodat hij vatbaar blijft voor herziening van die aanvankelijke inzichten ${ }^{\text {t3 }}$.

De mate waarin de rechter aan die eis kan voldoen, zal in hoge mate afhangen van zijn opvatting over zijn rol binnen het strafproces. Van wezenlijk belang is dat de rechter zich realiseert dat achter de toets van het gedrag van verdachte aan de door de wetgever gestelde regels, in wezen een andere toets schuil gaat ${ }^{74}$. Dat is de toets van het (voorgenomen) gedrag van de overheid. De rechter dient te controleren of het Openbaar Ministerie zich houdt aan de in de wet voorgeschreven regels. Hij moet als onafhankelijke instantie controleren of de officier van justitie voor zijn bewering dat de verdachte een door straf bedreigde gedragsnorm heeft geschonden,

72 Men zou het gevaar van negatieve beinvlocding van de onbevooroordecldheid van de rechter door kennisneming van de stukken uit het vooronderzock, gedecltelijk kunnen ondervangen door alleen de President van het rechtsprekende college daartoe de bevoegheid te geven. De 'blanco' deelname van de andere leden van het college aan het onderzoek ter terechtzitting en de oordeclsvorming zou dan kunnen fungeren als het noodzakelijk tegenwicht. Tegen 'verboden informatic' die eerst ter zitting wordt geopenbaart, biedt een dergelijk voorstel geen oplossing. Hier blijft de persoonlijke houding van de rechter allesbepalend, maar kan een zekere waarborg worden gevonden in de omstandigheid dat een oordeel wordt opgedragen aan een rechterlijk college.

73 Zie A.L. Melai, De onbevangen strafrechter, D\&D 1975, p. $124 \mathrm{t} / \mathrm{m} 127$.

74 J.M. Reijntjes, Strafrechtelijk bewijs in wet en praktijk, Arnhem 1980, p. $6 \mathrm{en} 7$. Zie in dit verband ook: J.F. Nijboer, Kanttekeningen bij het rapport 'De bedreigde getuige', Recht en Kritiek 1984, p. 89. 
voldoende wettig bewijs aandraagt dat uiteindelijk voldoet aan zijn subjectieve eisen van kwaliteit en betrouwbaarheid (zijn overtuiging) ${ }^{7 /}$.

\subsection{Conclusie}

Van de rechter kan niet worden geëist dat hij op grond van de kennisneming van de stukken uit het vooronderzoek niet tot een zekere overtuiging komt omtrent het gepleegd zijn van de telastegelegde feiten. Ook kan van hem niet worden verlangd dat wat hij ter zitting uit tweede hand hoort, op hem geen indruk maakt. Hij heeft daarop geen invloed. Wat wel van hem kan en mag worden geëist is dat hij hetgeen hij leest of hoort, controleert en dat hij zijn oordeel velt op basis van door hem zelf gecontroleerde informatie. In feite vraagt de negatief wettelijke bewijsleer niet meer dan dat, door de rechter bij zijn oordeel in beginsel te binden aan bewijsmiddelen die zich lenen voor een dergelijke controle. De negatief wettelijke bewijsleer is normatief van aard. Het vormt een opdracht aan de rechter bij de bewijsbeslissing een kritische attitude aan de dag te leggen. Zijn taak is primair gelegen in het oordelen en niet in het veroordelen.

\section{Het onmiddellijkheidsbeginsel sinds het 'De auditu'-arrest}

Kort na de uitspraak in het 'De auditu'-arrest schreef Van Dijck:

"In theorie is door het de auditu arrest de mogelijkheid geopend van een onderzoek ter terechtzitting, dat in hoofdzaak beperkt blijft tot de voorlezing van stukken uit het voorafgaand onderzoek, met name van processen-verbaal van politie en rechter-commissaris, houdende uitlatingen (verklaringen) van door hen gehoorde verdachten en getuigen. De rechter zal voortaan uitsluitend recht kunnen doen op de stukken, de dagvaarding van getuigen is voor het bewijs niet langer onmishaar. Verklaart een getuige op de terechtzitting anders dan in het voorbereidende onderzoek en meent de rechter, dat diens vroegere verklaring geloof verdient, welnu, wat nood? Men kan eenvoudig het proces-verbaal uit het voorbereidende onderzoek laten voorlezen en (materieel) recht doen op de daarin gerelateerde uitlatingen, "waarop de getuige zonder aannemelijke grond is teruggekomen". Onbeëedigde verklaringen kunnen aldus boven beëedigde worden gesteld.

(..) in theorie is thans dan toch mogelijk geworden een procesvorm, waarbij het zwaartepunt van het onderzoek geheel naar het voorbereidend onderzoek is verplaatst, en een wijze van onderzoek ter terechtzitting, waarbij èn het onmiddellijkheids-beginsel èn het beginsel van contradictoire behandeling èn, wat getuigen betreft, dat van beëediging, materieel te eenen male wordt miskend. Daarom doet het mij ook vreemd aan in het arrest

75 Zie ook J.F. Nijboer, Inleiding tot het strafrechtelijk bewijsrecht, vierde druk, Nijmegen 1992, p. $105 \mathrm{t} / \mathrm{m}$ 107: "(..) in laatste instantie gaat het toch vecleer om een persoonlijke houding of instelling dan om een onontkoombare gang van zaken." 
te lezen, dat noch de tekst, noch het systeem der wet tot de uitsluiting van het getuigenis van hooren zeggen moet leiden. Behoort dan tot het systeem der wet niet om een mondelinge behandeling te bevorderen (men denke bijvoorbeeld aan de ingevoerde, thans overigens mede verijdelbaar geworden beperking van het gebruik in appèl van het proces-verbaal der terechtzitting in eersten aanleg)? En om een contradictoire behandeling alsmede den waarborg van den eed te behouden? Na dit arrest, (..), is de mogelijkheid van terugkeer tot geheel verouderde procesvormen geopend. (..) De waarborgen, welke de wetgever voor een deugdelijk strafproces noodig achtte, kunnen thans in menig opzicht ijdel worden gemakt." ${ }^{176}$

\subsection{Schriftelijke aspecten van het modeme strafproces}

Hoezeer de voorspelling van Van Dijck praktijk is geworden, blijkt bijvoorbeeld uit de volgende woorden uit de conclusie van Advocaat-Generaal Fokkens bij een arrest van de Hoge Raad uit 1991: "In de meeste zaken worden geen getuigen ter zitting gehoord en is het oordeel van de rechter in belangrijke mate gegrond op de stukken van het vooronderzoek. ${ }^{m}$

Geheel in strijd met de bedoeling van de wetgever heeft het 'De auditu arrest' de deur open gezet voor een strafproces dat (uit historisch oogpunt wederom) in vergaande mate wordt gekarakteriseerd door zijn schriftelijk karakter. Uitgangspunt is geworden dat het bewijs wordt verzameld tijdens het voorbereidend onderzoek waarvan de opgemaakte processen-verbaal ter zitting worden voorgelezen. In de regel wordt volstaan met het voordragen van de korte inhoud van de processen verbaal (zie art. 297 lid 5 Sv). Verzoeken van de verdachte om getuigen ter zitting te horen, worden gehonoreerd in de vorm van een verwijzing naar de rechter-commissaris. De rechter oefent geen zelfstandige controle uit over de betrouwbaarheid en kwaliteit van de schriftelijk overgebrachte informatie, maar verlaat zich op de goede trouw van de opsporingsambtenaar of de rechter-commissaris en op diens goede

76 J.V. van Dijck, Het de auditu-arrest, NJB 1927, p. $52 \mathrm{l} / \mathrm{m} \mathrm{54.} \mathrm{Opvallend} \mathrm{is} \mathrm{het} \mathrm{dat} \mathrm{Van} \mathrm{Dijck,}$ die ook voordat het 'De auditu arrest' tot stand kwam zich al mengde in de discussie over de al dan nict toelaatbaarheid van een verklaring van horen zeggen voor het bewijs (Zie: Nieuwe literatuur over een nieuw wetbock, RM 1926, p. $81 \mathrm{t} / \mathrm{m}$ 85), eerst toen het leed al was geschied, zich uitliet over de ratio van zo'n verbod. Was voor het arrest zijn beschouwing over de materie aan de hand van de wettekst en de Mernorie van 'Toelichting vooral legistisch van aard, na het arrest zijn z'n bezwaren meer inhoudelijk. Voor het eerst wordt dan ook het onmiddellijkhcidsbeginsel genoemd, naast de mondelinge behandeling en het beginsel van contradictoire behandeling, overigens zonder nadere toclichting.

77 HR 29 oktober 1991, NJ 1992, 481. Zie ook de annotatic van T.M. Schalken onder het zgn. Finkensieper-arrest: HR 1 oktoher 1991, NJ 1992, 197, waar hij schrijft: "Als regel wordt het getuigenbewijs niet in tegenwoordigheid van de verdachte tijdens een openbare en contradictoire procedure ter terechtzitting gepresenteerd. Het is eerder regel dat getuigen (na verhoor door de politie) vrijwel uitsluitend door de rechter-commissaris tijdens het gerechtelijk vooronderzoek worden ondervraagd, waarna de zittingsrechter "op de stukken" vonnis wijst." 
weergave van hetgeen de getuige verklaarde. In dit verband is de moeite waard Nijboer aan te halen, die over deze gegroeide praktijk schrijft:

"Daar in de rechtspleging sinds 1926 via de auditu-constructies het onderzoek ter terechtzitting veelal slechts of in hoofdzaak het bespreken van het in het vooronderzoek verzamelde materiaal inhoudt, waaronder verklaringen van verdachte en getuigen, in de vorm waarin ze toen zijn vastgelegd in dat proces-verbaal, leidt deze praktijk methodologisch gezien tot een merkwaardig resultaat: de hypothese wordt naderhand geverifieerd met behulp van dezelfde gegevens - in dezelfde vorm gepresenteerd - als waarmee hij is opgesteld. Wanneer er geen nieuwe gegevens worden gebruikt in het eindonderzoek, zou men kunnen zeggen dat het neerkomt op een min of meer formele herhaling van het eerder onderzochte en de daarop gebaseerde hypothese. Anders en scherper gezegd: methodologisch bezien is een onderzoek ter terechtzitting, dat leidt tot beraadslaging, beslissing en motivering uitsluitend op basis van reeds in het vooronderzoek verzameld materiaal, niets anders dan een (soms bijna rituele en dus zinledige) bevestiging van wat we al wisten, namelijk dat de telastelegging als hypothese niet uit de lucht is gegrepen, oftewel dat het beschikbare materiaal toereikend is om de telastelegging te formuleren zoals deze is geformuleerd. Maar in een meer kritische of onafhankelijke zin wordt er niet zoveel bewezen. ${ }^{\text {78 }}$

Toch is deze praktijk van recht doen op stukken uit het vooronderzoek inmiddels zo gangbaar geworden dat het volgens sommigen ondenkbaar is dat deze nog wordt teruggeschroefd. Terugkeer naar een waarlijk mondeling strafproces in het merendeel van de zaken zou een gigantische extra werkbelasting van vooral de rechter en het Openbaar Ministerie opleveren ${ }^{x}$.

\subsection{Geheime aspecten van het modeme strafproces}

De 'de auditu'-praktijk heeft zijn dieptepunt gevonden in het verschijnsel van de anonieme getuigenverklaring. Reeds in 1938 wees de Hoge Raad een arrest waarin de verklaring van horen zeggen werd toegelaten, zonder dat de oorspronkelijke zegsman direkt aanwijsbaar was. In deze zaak ging het om de verklaring van een opsporingsambtenaar die zei klachten te hebben ontvangen over het rijgedrag van de verdachte. De Hoge Raad was van mening dat de wet de getuige niet verplichte diegenen te noemen die hem de bedoelde mededelingen hadden gedaan ${ }^{\infty}$.

78 J.F. Nijboer, Strafrechtelijk bewijs in de jaren '90: meer dan een papieren werkelijkheid?, D\&D 1990, p. 146 en 147.

79 G.J.M. Corstens, Van cri de justice naar anonieme getuigenverklaring: 75 jaar de-auditu-jurisprudentie, In: NJ 1913-1988, Annotatoren kijken terug, Zwolle 1988, p. 38.

80 HR 17 januari 1938, NJ 1938, 709, en G.J.M. Corstens (1988), a.w., p. 41. Zie ook HR 27 april 1931, NJ 1931, p. 1023. In dit arrest is niet helemaal duidelijk of gebruik werd gemaakt van een verklaring van horen zeggen, waarbij de oorspronkelijke zegsman nict tracecrbaar is. Opmerkelijk is dat Taverne in de noot onder dit arrest schrijft: "(..) zou het dan een zeer ongcbruikelijke, en m.i. zeer ongewenschte, de auditu zijn, daar geen zcgsman wordt genoemd." 
Vervolgens achtte de Hoge Raad in een arrest van 5 februari 1980 toelaatbaar, dat voor het bewijs gebruik werd gemaakt van een proces-verbaal van verhoor opgemaakt door de rechter-commissaris van een anonieme getuige. Volgens de Hoge Raad kon de rechter 'met inachtneming van de behoedzaamheid welke bij de waardering van de overtuigende kracht van zodanig bewijsmiddel is geboden', het proces-verbaal van het anonieme getuigenverhoor gebruiken ${ }^{\mathrm{s}}$. De Hoge Raad accepteerde zelfs dat een veroordeling uitsluitend of nagenoeg uitsluitend berust op verklaringen van anonieme personen ${ }^{22}$.

Wanneer men de verklaring van horen zeggen vergelijkt met de anonieme verklaring van horen zeggen, dan kan daarover het volgende worden opgemerkt. De mogelijkheid van controle van de betrouwbaarheid en kwaliteit van de overgebrachte informatie is bij het gebruik van de anonieme verklaring van horen zeggen nog beperkter dan bij de verklaring van horen zeggen. Ten aanzien van beide gereproduceerde vormen van bewijs mist de rechter de drie voordelen die hij wel heeft ter controle van de verstrekte informatie wanneer de oorspronkelijke bron ter zitting verschijnt. Het verschil tussen de verklaring van horen zeggen en de anonieme verklaring die door een derde wordt overgebracht, is echter dat de verdediging ten aanzien van de verklaring van horen zeggen meer mogelijkheden heeft om bij de rechter twijfel te zaaien. Via de bekendheid met de identiteit van de oorspronkelijke zegsman heeft de verdediging bijvoorbeeld nog inzicht in de relatie van de betreffende persoon tot de verdachte en de eventuele belangen die deze zou hebben om de verdachte te belasten. Met die informatie kan de verdediging de geloofwaardigheid van de oorspronkelijke getuige bekritiseren. Bij de anonieme getuigenverklaring mist de verdediging deze informatie en de daarmee samenhangende mogelijkheid ${ }^{\mathrm{B}}$.

81 HR 5 februari 1980, NJ 1980, 319. Zie ook de "ambtshalve ontboezeming" van A-G Haak bij dit arrest: "hier wordt een terrein betreden, dat zozeer indruist tegen het systeem der wet, tegen het principe van de onmiddellijkheid, dat onder omstandigheden kan worden gezegd, dat hier gebruik wordt gemaakt van een onwettig bewijsmiddel. (..) Het is een kwestie van bclangenafweging, waarbij ik van mening ben, dat het belang van de verdachte bij de controleerbaarheid en de "openbaarheid" van het bewijs uiteindelijk zwaarder weegt." Zie over deze uitspraak ook: J.F. Nijboer, De anonieme informant als getuige in het strafprocesrecht, Recht en Kritick 1980. p. 426: "Op deze manier is de grens naar de eertijds zo gevreesde geheime aanklachten overschreden". Zie ook HR 4 mei 1981, NJ 1982, 268 en A.H.J. Swart, Rechten van de mens in de strafrechtspleging, D\&D 1989, p. 564, die schrijft: "Deze beslissingen zijn niet alleen opmerkelijk omdat deze figuur niet van de hand wordt gewezen. Ze zijn dat ook omdat het Wetboek van Strafvordering anonieme getuigen in het geheel niet kent en de Hoge Raad daarom als wetgever optreedt. En omdat noch in de cassatiemiddelen noch door de Hoge Raad zelf gewag wordt gemaakt van het bestaan van verdragsbepalingen waarin aan iedere verdachte het recht op ondervraging van getuigen à charge in onvoorwaardelijke termen wordt gegarandeerd."

82 Zie bijvoorbeeld HR 4 mei 1981, NJ 1982, 268; HR 25 september 1984, NJ 1985, 426; HR 12 november 1985, NJ 1986, 409.

83 Zie Taru Spronken, Anonieme getuigen: het strafproces op de helling, In: 'Niets dan de waarheid'; Getuigenbewijs in het civiel- en strafrecht, Jonge Balie 1988, Zwolle 1988, p. 31 en 32. 
Of de rechter de gereproduceerde infomnatie zal geloven of niet zal vooral afhangen van het verhaal waarin die informatie past. Het probleem daarbij is dat het verhaal van de officier van justitie, zoals dat voortvloeit uit de stukken van het vooronderzoek, voor de rechter uitgangspunt vormt ${ }^{24}$. Het alternatieve verhaal van de verdediging verkeert daarbij bij voorbaat in een achterstandssituatie. Heeft de verdediging bij de verklaring van horen zeggen nog de mogelijkheid tot een alternatief verhaal, bij het gebruik van de anonieme verklaring valt er voor de verdediging weinig meer te vertellen.

\subsection{Conclusie}

Heeft het huidige Nederlandse strafproces met de aanvaarding van de verklaring van horen zeggen zijn schriftelijke karakter herwonnen, met de introductie van de anonieme getuigenverklaring, heeft het ook weer geheime aspecten ${ }^{\mathrm{BS}}$ ontwikkeld. Het onmiddellijkheidsbeginsel vindt in de praktijk nauwelijks erkenning. Dit is niet alleen ten koste gegaan van de openbaarheid, maar ook van het accusatoire karakter van het strafproces en de controle op het optreden van politie en justitie ${ }^{*}$.

84 Zie H.F.M. Crombag, P.J. van Koppen en W.A. Wagenaar (1992), a.w., p. 450: "Eén ding lijkt zcker tc zijn: de rechter begint met het verhaal van het openbaar ministeric en niet met het verhaal van de verdediging."

85 Zie in dit verband J.C.M. Leijten, Overpeinzingen van een andersdenkende, NJB 1987, p. 1455, waar hij schrijft: "Ik betreur het in hoge mate dat ik (..) mij nict (veel) krachtiger heb verzet tegen het fenomeen van de anonieme getuige. Het is - benoembare uitzonderingen daargelaten - onaanvaardbaar want het druist in tegen een grondbeginsel van het huidige strafproces, dat niet, ook nict ten dele geheim mag zijn, m.n. nict voor de verdachte. (..) We hadden er nonit (..) aan mocten beginnen of we hadden (..) ons zelf terug moeten rocpen van deze heilloze weg. Want zij is in staat ons strafproces tot de kern te misvormen."

Over de mate waarin het gebruik van anonieme verklaringen voorkomt, schrijft Leyten in hetrelfde artikel: "Nog maar kort geleden kon men in de krant lezen dat hei Haagse Hof en zijn ProcureurGeneraal H.A. Holthuis zich publiekelijk tijdens een zitting er over beklaagden, dat vecl te veel van anonieme getuigen gebruik gemaakt werd en kort daarna stond in mijn plaatselijke courant dat een verkeersdeelnemer wegens rijden door rood licht werd veroordeeld op grond van een anonieme getuigenis."

86 Dat ook die controle niet gemist kan worden blijkt bijvoorbeeld uit de zaak Bruinsma. Het bewijs in die zaak was gebaseerd op verklaringen van cen anonieme getuige die later dezclfde persoon bleck te zijn als de getuige die gewoon onder vermelding van zijn personalia een verklaring had afgelegd en die bovendien helemaal nict om anonimiteit had gevraagd. Eerder kwam in Assen ecn geval aan het licht waarin gewerkt was met twee anonieme getuigenverklaringen dic afkomstig bleken te zijn van cen en dezelfde persoon. Zie G.P.M.F. Mols, Crimineel Jaarbock 1992 , Nijmegen 1992, p. 133 en 134. 


\section{Samenvatting}

Aan de hand van de wettelijke regeling is niet eenduidig vast te stellen in hoeverre de makers van ons huidige Wetboek van Strafvordering het onmiddellijkheidsbeginsel aan het strafproces ten grondslag hebben willen leggen.

Het lijkt erop dat de wetgever het strafproces met name een openbaar en mondeling karakter heeft willen geven. Vanuit dit oogpunt werd noodzakelijk geacht dat getuigen ter zitting verschenen om daar mondeling hun verklaring af te leggen. Op dit uitgangspunt werd echter van aanvang aan een belangrijke uitzondering uit praktische overwegingen onontbeerlijk geacht. Voor zover het ging om getuigenverklaringen van bijzondere ambtenaren, werden deze ook in schriftelijke vorm geaccepteerd als grondslag voor het rechterlijk oordeel.

Over de vraag of de verklaring van horen zeggen voor het bewijs toelaatbaar is, heeft de wetgever zich niet ondubbelzinnig uitgelaten. Het in de Memorie van Toelichting gemaakte onderscheid tussen bewijsgrond en bewijsmiddel vormde een bron van veel onduidelijkheid. Het lijkt erop dat de makers van het wethoek deze kwestie aan de praktijk hebben willen overlaten.

De Hoge raad besliste in het 'De auditu'-arrest dat de mondelinge dan wel schriftelijke getuigenverklaring van horen zeggen niet door de wettelijke bewijsregeling werden uitgesloten als basis voor een veroordeling. Dat de Hoge Raad in dit arrest 'om' ging is verklaarbaar, wanneer bedacht wordt dat Taverne deel uitmaakte van het college dat verantwoordelijk was voor deze uitspraak. Taverne was een groot vonrstander van de toelating van de verklaring van horen zeggen voor het bewijs. Zijn opvattingen werden gevoed door zijn strijd tegen de juridische ficties. Een van die juridische ficties was volgens hem dat het negatief wettelijk bewijsstelsel aan de rechter vraagt bij zijn oordeel buiten beschouwing te laten, hetgeen hij wel weet. Een dergelijke wettelijke eis berust op een onmogelijkheid en moet om die reden niet worden gesteld.

Analyse van de negatief wettelijke bewijsleer toont aan, dat de rechter het gebruik van verklaringen van horen zeggen wordt verboden, niet vanwege de mogelijke onbetrouwbaarheid van de daardoor overgebrachte informatie, maar vanwege de grotere kans op vertekening (onbetrouwbaarheid) van die informatie als gevolg van de reproduktie daarvan. Bewijsuitsluitingsregels die gebaseerd zijn op argumenten van betrouwbaarheid staan echter op gespannen voet met het uitgangspunt van de vrije bewijswaardering. Dit beginsel gaat ervan uit gaat dat de bewijskrachtwaardering van bewijs aan de rechter moet worden overgelaten, omdat de waarde van bewijs afhankelijk is van de bijzondere omstandigheden van het geval. De reden dat gereproduceerd bewijs als oordeelsgrondslag moet worden gediskwalificeerd moet dan ook niet worden gezocht in de kans op onbetrouwbaarheid van de informatie vanwege de reproduktie maar in het gebrek aan controleerbaarheid van de informatie als niet de oorspronkelijke bron daarvan te ritting gepresenteerd wordt. De negatief wettelijke bewijsleer eist in feite niet meer dan dat de rechter het hem door de officier van justitie gepresenteerde bewijs toetst op zijn kwaliteit en betrouwbaarheid. 
Bewijs dat zich daarvoor niet leent, mag de rechter voor het bewijs dat de verdachte het hem telastegelegde feit heeft begaan, niet gebruiken ook al wordt hij daarmee geconfronteerd. Ervan uitgaande dat de taak van de rechter primair bestaat uit het heoordelen van het (voorgenomen) gedrag van de overheid, wordt daarmee van de rechter een opstelling gevraagd die misschien niet makkelijk, maar wel mogelijk is.

Sinds het 'De auditu'-arrest is het horen van getuigen ter terechtzitting tot uitzondering geworden. In de meeste zaken baseert de rechter zijn oordeel op de stukken uit het vooronderzoek. Ons strafproces kenmerkt zich dientengevolge in strijd met de bedoelingen van de wetgever door een vergaand schriftelijke karakter. Daarnaast kent ons strafproces door de introductie van de anonieme getuigenverklaring ook weer geheime aspecten. Het onmiddellijkheidbeginsel leidt een moeilijk bestaan. De openbaarheid, het accusatoire karakter en de autonoom rechterlijke controle op het optreden van politie en justitie zijn nog steeds geen vanzelfsprekende verworvenheden. 



\section{Het onmiddellijkheidsbeginsel en het recht op een 'fair trial'}

\section{Inleiding}

Het Nederlandse strafprocesrecht wordt niet alleen beheerst door bronnen van nationaal recht, maar ook door bronnen van internationaal recht. In hoofdstuk drie werden die bronnen van internationaal recht met het oog op de structuur van het onderzoek bewust buiten beschouwing gelaten. In dit hoofdstuk daarentegen staat de voor het Nederlandse strafprocesrecht belangrijkste bron van internationaal recht, het EVRM, centraal. Vour de inrichting van het strafproces is met name art. 6 van dit verdrag van belang, waarin aan iedere verdachte het recht op een 'fair trial' wordt gegarandeerd. Met het oog op het onmiddellijkheidsheginsel zal met name aandacht worden besteed aan de jurisprudentie van het EHRM en de ECRM met betrekking tot art. 6 lid 1 in samenhang met lid 3 sub d EVRM, waarin als een onderdeel van het recht op een 'fair trial', het recht van iedere verdachte op het horen van getuigen ligt opgesloten. Deze Europese jurisprudentie heeft op nationaal niveau een nieuwe discussie op gang gebracht in hoeverre de rechter zijn oordeel mag baseren op de stukken van het vooronderzoek en anoniem bewijs.

Onderzocht wordt in hoeverre het onmiddellijkheidsbeginsel ten grondslag ligt aan het recht op een 'fair trial'. Dit onderzoek vindt plaats aan de hand van jurisprudentie van de ECRM en het EHRM over het recht van de verdachte op het (doen) ondervragen van getuigen à charge'. Bovendien wordt bekeken in hoeverre de invloed

1 De schaarse jurisprudentic van het EHRM over het recht van de verdachte tot het oprocpen en ondervragen van getuigen à décharge blijft hier verder buiten beschouwing. De reden daarvoor is dat deze jurisprudentic niet zo zeer de vraag betreft naar de vorm waarin het (in dit geval: ontlastende) getuigenbewijs ter kennis van de zittingsrechter dient te komen, alswel de vraag naar de omvang van het onderzoek ter terechtritting. Dit blijkt bijvoorbeeld uit de Vidal zaak (EHRM 22 april 1992, Series A, vol. 235-B), waarin het EHRM overwong (\$33): "As a general rule, it is for the national courts to assess the evidence before them as well as the relevance of the evidence which the defendants seek to adduce. More specifically, Article 6 §3(d) leaves it to them, again as a general rule, to assess whether it is appropriate to call witnesses, in the "autonomous" sense given to that word in the Convention system; it does not require the attendance and examination of every witness on the accused's behalf: its cssential aim, as is indicated by the words 'under the same conditions', is a full 'equality of arms' in the mattcr." 
van het EVRM op het Nederlandse strafprocesrecht verandering heeft gebracht in het schriftelijke en soms geheime karakter van het onderzoek ter terechtzitting en dus heeft bijgedragen aan de erkenning van het onmiddellijkheidsbeginsel in het Nederlandse strafproces. Maar eerst zal iets worden gezegd over de achtergrond en de wijze waarop het EVRM doorwerkt in het Nederlandse strafprocesrecht.

\section{Enige achtergrond en doorwerking van het EVRM}

Het EVRM is voor Nederland in werking getreden op 31 augustus 1954. Nederland hehoort tot de landen die het initiatief tot dit verdrag hebben genomen. Aanleiding tot het sluiten van deze internationale overeenkomst werd onder meer gevonden in het tijdens de Tweede Wereldoorlog gegroeide inzicht dat grondrechten binnen een nationaal kader van staatswege kunnen worden gefrustreerd en om die reden aanvulling behoeven in de internationaalrechtelijke sfeer. De waarborgen die grondrechten de individuele burger bieden, mogen niet afhankelijk worden gesteld van de welwillendheid van de nationale machthebbers ${ }^{2}$.

Een van de belangrijkste doelstellingen van het EVRM vormt de bescherming van de individuele vrijheid tegen machtsmisbruik door de overheid. Daartoe legt het verdrag in art. 1 de verdragsstaten de verplichting op de rechten en vrijheden te garanderen die in Titel 1 van het verdrag zijn opgenomen. Tot die rechten behoort ook het recht van iedere verdachte op een 'fair trial', neergelegd in art. 6 EVRM. Art. 6 EVRM heeft ten aanzien van ons strafprocesrecht rechtstreekse werking. Dit betekent dat iedere verdachte in ons land voor de nationale rechter een beroep kan doen op deze bepaling. Ingevolge art. 93 van onze Grondwet zal de rechter 'een ieder verbindende bepalingen' van verdragen waarbij Nederland is aangesloten,

Hoewel de vraag naar de vorm van het bewijs samenhangt met de vraag naar de omvang van het onderzoek ter terechtzitting, in die zin dat beide vragen moeten worden beantwoord in het licht van het streven naar materiële waarheidsvinding, dienen zij met het oog op de noodzakelijke beperking van dit onderzoek van elkaar te worden onderscheiden. Het onmiddellijkheidsbeginsel eist dat de oorspronkelijke bronnen van het hewijs, dat de officier van justitie aandraagt voor de bewering dat de verdachte het ten laste gelegde feit heeft begaan, ter zitting worden gepresenteerd. Alleen dan is de rechter in staat dit bewijs op zijn betrouwbaarheid en kwaliteit te toetsen, bijvoorbeeld door de oorspronkelijke zegsman van een voor de verdachte belastende verklaring te confronteren met de beweringen van een getuige à décharge. Of de rechter bij zijn controle van het belastende bewijs gebruik dient te maken van verklaringen van getuigen à décharge is weliswaar een vraag die met het oog op het streven naar materiële waarheidsvinding in beginsel positief moet worden beantwoord, maar die buiten de strekking van het onmiddellijkheidsbeginsel valt.

2 Zie P. van Dijk en G.J.H. van Hoof, De Europese conventic in theorie en praktijk, derde druk Nijmegen 1990, p. 1; A.E. Harteveld, B.F. Keulen en H.G.M. Krabbe, Het EVRM en het Nederlandse strafprocesrecht, Groningen 1992, p. 9; J.D. den Hartog. Art. 6 EVRM: Grenzen aan het streven de straf eerder op de daad te doen volgen, Antwerpen 1992, p. 31 en 32; A.E. Alkema, De betekenis van het EVRM voor de Nederlandse constitutie, In: 40 jaar Europese conventie voor de rechten van de mens en de Nederlandse rechtsorde, Leiden 1990, p. 3. 
moeten toepassen wanneer deze bepalingen zich daartoe lenen. Dat is het geval met al die verdragsbepalingen die geen nadere uitwerking behoeven door de nationale wetgever, alvorens door de rechter te kunnen worden toegepast'. Van het EVRM zijn dat de meeste bepalingen waarin de rechten en vrijheden van het verdrag worden gegarandeerd. Zo ook art. 6 EVRM4.

Het EVRM heeft twee organen in het leven geroepen die erop moeten toezien dat de lidstaten hun verdragsverplichtingen naleven. Deze toezichtshoudende organen zijn de ECRM en het EHRM's. De verdachte die meent dat hem ondanks een beroep op art. 6 EVRM voor de nationale rechter geen eerlijke behandeling van zijn strafzaak ten deel is gevallen, kan daarover bij deze organen klagen. Nederland erkent het individuele klachtrecht van zijn burgers sinds 24 mei $1960^{6}$.

\section{Het recht op het horen van getuigen a charge als onderdeel van het recht op een 'fair trial'}

In het eerste lid van art. 6 EVRM wordt aan iedere verdachte het recht toegekend op een eerlijke en openbare behandeling van zijn zaak, binnen een redelijke termijn, door een onafhankelijk en onpartijdig gerecht dat bij wet is ingesteld. Dat betekent ingevolge het derde lid sub d onder meer dat jedere verdachte in het bijzonder het recht heeft om de getuigen à charge te ondervragen of te doen ondervragen.

Het is met name de jurisprudentie van de Straatsburgse organen met betrekking tot het recht op het horen van voor de verdachte belastende getuigen die de discussie over het belang van het onmiddellijkheidsbeginsel op nationaal niveau nieuw leven heeft ingeblazen. Want wat betekent het recht op het ondervragen van getuigen à charge voor het bewijs? Betekent het dat alleen de verklaring van de oorspronkelijke zegsman die ter zitting wordt afgelegd in het bijzijn van de verdachte door de rechter aan het zijn oordeel ten grondslag mag worden gelegd? Hebben daarmee de stukken uit het vooronderzoek (schriftelijke verklaringen van horen zeggen en schriftelijke getuigenverklaringen) hun waarde voor het bewijs verloren? Hoe zit het met het gebruik van de mondelinge verklaring van horen zeggen? En niet in de laatste plaats, hoe verhoudt zich het recht op het horen van getuigen à charge tot het gebruik van de anonieme getuigenverklaring (schriftelijke dan wel mondelinge verklaring van horen zeggen zonder dat de identiteit van de oorspronkelijke zegsman bekend is)?

3 Zic A.W. Heringa, $\dot{\Upsilon}$. Zwart, De Nederlandse (irondwcl, Zwolle 1!91, p. $24 k$ en 2117 ; J.D. den Hartog (1992), a.w., p. 179 t/m 183.

4 Zic P. van Dijk en G.J.H. van Hoof (1990), a.w., p. 12 en 13; A.F. Harteveld c.a. (19)2), a.w., p. 12.

5 Zie over deze toezichthoudende organen uitgcbreider: P, van Dijk tn G.J.H. van Hoof (1990), a.w., p. $22 \mathrm{t} / \mathrm{m} 32$.

6 Zic A.E. Hartcveld e.a., (1992), a.w., p. 9. 
Langzamerhand worden door de toenemende jurisprudentie van de Straatsburgse organen de contouren van het ondervragingsrecht van de verdachte zichtbaar.

\subsection{De hoofdregel betreffende het recht op het horen van getuigen}

De ECRM en het EHRM hebben in hun jurisprudentie herhaaldelijk uitgemaakt dat het aan de nationale lidstaten is overgelaten te bepalen wat zij als bewijsmiddel in een strafproces erkennen en welke bewijswaarde zij hieraan toekennen, mits daarbij de rechten en vrijheden van de verdachte die het verdrag beoogt te beschermen maar in acht worden genomen'. Niet de betrouwbaarheid van het bewijsmiddel, noch de rechtmatige verkrijging van het bewijsmiddel ${ }^{8}$ op zichzelf staan ter beoordeling van de Straatsburgse toezichthoudende organen. De ECRM en het EHRM beschouwen alleen als hun taak te controleren of de procedure in haar geheel, inclusief de wijze waarop het bewijs, al dan niet met toepassing van dwangmiddelen, is verzameld, als eerlijk kan worden aangemerkt'. Eerlijk wil zeggen dat de rechten en vrijheden van de verdachte die het verdrag beoogt te beschermen in voldoende mate in acht zijn genomen.

Eén van die rechten die het verdrag beoogt te beschermen, is het recht op het horen van getuigen (art. 6 lid 3 sub d). In de Barberà c.s. zaak overwoog het EHRM dat dit recht "not only entails equal treatment of the prosecution and the defence in this matter, but also (..) that the hearing of witnesses must in general be adversarial." Daar komt, aldus het Hof, bij dat een verdachte "is entitled to take part in the hearing and to have his case heard in his presence by a tribunal ${ }^{\text {min }}$. Deze door het verdrag te beschermen rechten van de verdachte leiden volgens het Hof tot de slotsom dat "all the evidence must in principle be produced in the presence of the accused at a public hearing with a view to adversarial argument. ${ }^{{ }^{\prime 1}}$ Dit is de hoofdregel die door de Straatsburgse organen in alle uitspraken inzake het recht van de verdachte op het horen

7 Barberà, Messegué en Jabardo zaak, EHRM 6 december 1988, Series A, vol. 146, \$68; Kostovski zaak, EHRM 20 november 1989, Series A, vol. 166, $\$ 39$; Windisch zaak, EHRM 27 september 1990, Series A, vol. 186, \$25; Delta zaak, EHRM 19 december 1990, Series A, vol. 191, §39; Isgro zaak, EHRM 19 februari 1991, Series A, vol. 194-A, \$ 48; Asch zaak, EHRM 26 april 1991, Series A, vol. 203, \$26; Vidal zaak, EHRM 22, april 1992, Series A, vol. 235-B, § 33; Lüdi zaak, EHRM 15 juni 1992, Series A, vol, 238, $\$ 43$; Saïdi zaak, EHRM 20 september 1993, Series A, vol. 261-C, $\S 43$.

8 Schenk zaak, EHRM 12 juli 1988, Series A, vol. 140, \$ 46: "While Art. 6 Convention guarantees the right to a fair trial, it does not lay down any rules on the admissibility of evidence as such, which is therefore primarily a matter for regulation under national law. The Court therefor cannot exclude as a matter of principle and in the abstract that unlawfully obtained evidence of the present kind may be admissible. It has only to ascertain whether Mr. Schenk's trial as a whole was fair."

9 Zie A.E. Harteveld e.a., (1992), a.w., p. 9.

10 Zie ook de Colozza zaak, EHRM 12 februari 1985, Series A, vol. 89.

11 Barberà, Messegué en Jabardo zaak, EHRM 6 december 1988, Series A, vol. 146, $\$ 78$. 
van getuigen steeds weer wordt herhaald ${ }^{12}:$ Met het $о 0 g$ op het recht op een contadictoire procesbehandeling dient in beginsel alle bewijs ter terechtzitting - dat wil zeggen ten overstaan van de rechter -, in aanwezigheid van de verdachte geproduceerd te worden.

\subsubsection{Autonome interpretatie van verdragstermen}

Teneinde het onder art. 6 lid 3(d) genoemde recht effectief te doen zijn, dient, evenals andere verdragstermen ${ }^{\text {13 }}$, de term 'getuigen' naar vaste rechtspraak van de ECRM en het EHRM 'autonoom' uitgelegd te worden. Dat betekent dat het er in de ogen van de Straatsburgse organen niet toe doet of iemand volgens het recht van de nationale lidstaat formeel als getuige wordt aangemerkt of niet. Van belang is alleen of een verklaring van iemand, in welke vorm deze ook ter kennis van de rechter komt, voor het bewijs wordt gebnuikt ${ }^{19}$. Met deze autonome interpretatie wordt voorkomen dat door middel van etikettenzwendel het verdrag wordt ontdo$\mathrm{ken}^{15}$. Illustratief voor deze autonome interpretatie van de term 'getuigen' zijn de overwegingen van het EHRM in de Kostovski zaak. In die zaak tegen Nederland was voor het bewijs gebruik gemaakt van door de politie opgemaakte processenverbaal inhoudende verklaringen van twee anonieme getuigen (art. 344 lid 1 sub $2 \mathrm{~Sv}$ ) en van door de rechters-commissarissen opgemaakte processen-verbaal inhoudende de beëdigde verklaringen van eén van die anonieme getuigen die overeenkomstig art. $295 \mathrm{~Sv}$ ter zitting werden voorgelezen en dientengevolge als formele getuigenverklaringen conform Nederlands recht konden worden aangemerkt (art. 342 lid

12 Kostovski zaak, EHRM 20 november 1989, Series A, vol. 166, $\$ 41$; Windisch zaak, EHRM 27 september 1990, Series A, vol. 186, \$26; Delta zaak, EHRM 19 december 1990, Series A, vol. 191, §36; Isgrò zaak, EHRM 19 februari 1991, Series A, vol. 194-A, § 34; Asch zaak, EHRM 26 april 1991, Series A, vol. 203, § 27; Lüdi zaak, EHRM 15 juni 1992, Series A, vol. 238, \$ 47; Saïdi zaak, EHRM 20 september 1993, Series A, vol. 261-C, $\$ 43$.

13 Zie Bönisch zaak, EHRM 6 mei 1985, Series A, vol. 92, \$\$ 31 en 32.

14 Zie ook de overwegingen van de ECRM in de Unterpertinger zaak, EHRM 24 november 1986, Series A, vol. 110 , $\$ \$ 70$ en 71 : "In this respect, the Commission recalls its opinion expressed in the Bönisch case according to which as other terms of the Convention the term "witnesses" in Art. 6 (3)(d) must be understood as having an autonomous meaning which may be wider than that of "witnesses" in the technical sence as understood in the domestic legal system. Therefore it cannot be decisive in the present case that according to the applicable Austrian law the applicant's relatives did not act as witnesses in the formal sense when they made their statements before the police, and that these statements were not recognised as evidence given by witnesses, but rather as some kind of documentary evidence, when they were subsequently used in court."

15 Zie ook J.D. den Hartog (1992), a.w., p. 38. Zie ook de Öztürk zaak, EHRM 21 februari 1984, Series A, vol. $73, \S 49$ : "Nevertheless, if the Contracting States were able at their discretion, by classifying an offence as "regulatory" instead of criminal, to exclude the operation of the fundamental clauses of Article 6 and 7, the application of these provisions would be subordinated to their sovereign will." 
$1 \mathrm{~Sv})$. Het Hof overwoog: "The court notes that only one of the authors of the statements -namely the person whose statements were read out at the trial - was, under Netherlands law, regarded as a 'witness'. However, in view of the autonomous interpretation given to this term, both authors should be so regarded for the purposes of Article $6 \$ 3(d)$ of the Convention, since the statements of both of them, whether read out at the trial or not, were in fact before the court and were taken into account by it. ${ }^{m b}$

\subsubsection{Conclusie}

Uit de in de Europese jurisprudentie geformuleerde hoofdregel betreffende de productie van het bewijs ter terechtzitting in aanwezigheid van de verdachte en ten overstaan van de rechter in samenhang met de autonome interpretatie van de verdragsterm 'getuigen' kan worden geconcludeerd dat de oorspronkelijke zegsman in beginsel ter zitting dient te verschijnen om daar zijn belastende verklaring af te leggen en door of vanwege de verdachte gehoord te kunnen worden.

\subsection{Hardheid van de hoofdregel}

In de Lüdi zaak overweegt het EHRM: "According to the Court's consistent case-law, all the evidence must normally be produced in presence of the accused at a public hearing with a view to adversarial argument" En dan komt het: "There are exceptions to this principle, but they must not infringe the rights of the defence; (..). ${ }^{\text {at }}$

Wat wil dat zeggen? Betekent dit dat de rechter onder omstandigheden voor zijn oordeel genoegen mag nemen met gereproduceerd bewijs?

Hoewel in dit hoofdstuk hoofdzakelijk de reikwijdte van het recht van de verdachte op het (doen) horen van getuigen à charge aan de orde komt, mag hier niet voorbij worden gegaan aan de overwegingen van het $H o f$ in de Barberà c.s. zaak over de presentatie van stukken van overtuiging ter terechtzitting. Bij het antwoord op de gestelde vraag naar de toelaatbaarheid van gereproduceerd bewijs wordt daarom onderscheid gemaakt tussen stukken van overtuiging zoals een wapen en dergelijke en verklaringen van personen die als bewijs worden gebruikt.

\subsubsection{Gereproduceerde stukken van overtuiging}

In de Barberà c.s. zaak overweegt het Hof aangaande de stukken van overtuiging: 'The weapons, other items and documents found at the applicants' homes, and subse-

16 Kostovski zaak, EHRM 20 november 1989, Series A, vol. 166, § 18 en 40.

17 Lüdi zaak, EHRM 15 juni 1992, Series A, vol. 238, § 47. 
quently at the places indicated by Mr Barberà and Mr Messegrue, were not produced in court at the trial, although they were relied upon by the prosecution as evidence. That being so, the defence was unable to challenge their identification or relevance in a fully effective manner. ${ }^{\text {ms }}$ Deze omissie woog voor het Hof zwaar bij zijn uiteindelijke oordeel over de 'fairness' van de procedure die de verdachten was geboden: "Having regard to the belated transfer of the applicants from Barcelona to Madrid, the unexpected change in the court's membership immediately before the hearing opened, the brevity of the trial and, above all, the fact that very important pieces of evidence were not adequately adduced and discussed at the trial in the applicants' presence and under the watchful eye of the public, the Court concludes that the proceedings in question, taken as a whole, did not satisfy the requirements of a fair and public hearing. ${ }^{m 9}$

Door uitsluitend de processen-verbaal uit het vooronderzoek ter zitting te presenteren waarin verhaald werd over de stukken van overtuiging - het gaat hier om een schriftelijke getuigenverklaring - werd de verdediging in haar recht op een contradictoire procesbehandeling beperkt. Deze beperking, tesamen met de andere geconstateerde tekortkomingen in de procedure leidde tot het oordeel dat de verdachten geen eerlijk proces ten deel was gevallen.

Kan uit deze uitspraak van het Hof nu geconcludeerd worden dat stukken van overtuiging steeds in originele vorm ter zitting gepresenteerd dienen te worden, wil in voldoende mate aan de rechten van de verdachte tegenmoet gekomen worden? De typisch aard van de door de ECRM en het EHRM uitgevoerde controle, namelijk of de gevolgde procedure in zijn geheel als 'fair' kan worden aangemerkt, rechtvaardigt een dergelijk algemene conclusie niet. Bedacht moet worden dat de uitspraken van de Straatsburgse organen steeds zijn toegesneden op het desbetreffende individuele geval. De bijzondere omstandigheden van het individuele geval kunnen van doorslaggevende betekenis zijn. Daarom moet bij het formuleren van algemeen geldende regels uit de Straatsburgse jurisprudentie grote voorzichtigheid worden betracht ${ }^{20}$.

\subsubsection{Gereproduceerde getuigenverklaringen}

Over het gebruik van gereproduceerde getuigenverklaringen als bewijs overwoog het Hof voor het eerst in de Unterpertinger zaak: "In itself, the reading out of statements (..) cannot be regarded as being inconsistent with. Article $6 \$ \$ 1$ and $3(d)$ of the Convention, but the use of them as evidence must nevertheless comply with the rights

Barberà, Messegué en Jabardo zaak, EHRM 6 december 198s, Scries A, vol. 146, $\$ 88$.

Barberà, Messegué en Jabardo zaak, EHRM 6 december 1988, Series A, vol. 146, § 89.

Zic G.P.M.F. Mols, Over het onmiddellijkhcidsbeginsel in strafraken, In: Rechtsbeginselen, themanummer AA 1991, p. 169. Zic hierover bijvoorbeeld ook E. Myjer, Hoe ver draagt het verdrag?, In: 40 jaar Europese conventie voor de rechten van de mens en de Nederlandse rechtsorde, Leiden

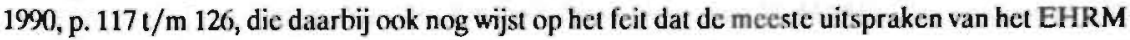
tegen een 'buitenland' zijn gewezen. 
of the defence, which it is the object and purpose of Article 6 to protect. This is especially so where the person "charged with a criminal offence", who has the right under Article $6 \$ 3(d)$ to "examine or have examined" witnesses against him, has not had an opportunity at any stage in the earlier proceedings to question the persons whose statements are read out at the hearing."21

Sinds deze uitspraak laten Commissie en Hof zich in soortgelijke bewoording uit, echter daarbij bijna steeds de hoofdregel benadrukkend. In de Kostovski zaak bijvoorbeeld overweegt het Hof: "In principle, all evidence must be produced in the presence of the accused at a public hearing with a view to adversarial argument. This does not mean, however, that in order to be used as evidence statements of witnesses should always be made in court: to use as evidence such statements obtained at the pre-trial stage is not in itself inconsistent with paragraphs $3(d)$ and 1 of article 6 , provided that the rights of the defence have been respected." ${ }^{\text {m2 }}$

In de Windisch zaak drukt het Hof zich als volgt uit: "All the evidence must in principle be produced in the presence of the accused at a public hearing with a view to adversarial argument. However, the use as evidence of statements obtained at the pre-trial stage is not always in itself inconsistent with paragraphs $3(d)$ and 1 of Article 6 , provided the right of the defence have been respected. ${ }^{n 23}$. Wederom wordt hier de hoofdregel bevestigd.

De ECRM heeft zich wat betreft het benadrukken van het hoofdregel nog stelliger uitgedrukt dan het EHRM. In de Delta zaak bijvoorbeeld overweegt zij:

"The reading out during a trial of statements made by witnesses during the criminal investigation is in practice admissible in exceptional cases when necessary, but only on the strict condition that its use as evidence respects the rights of the defence, which it is one of the purposes of Article 6 to protect. (..) On this subject, the Commission believes in the light of its decisions and in the light of the judgements of the Court that a principle may be discerned: save in exceptional circumstances, requiring specific justification, witnesses must be heard in the presence of the accused at a hearing where both parties can present their arguments and which, since it is subject to public scrutiny, offers a tangible guarantee to the fairness of the proceedings. ${ }^{\text {mil }}$

\subsubsection{Dubbele voorwaarde}

Zo stellig als de Commissie in haar overwegingen in de Delta zaak, heeft het Hof zich nowit uitgelaten. Het is de vraag of in de geciteerde en soortgelijke overwegingen van het Hof ruals de Commissie blijkbaar van mening is - een dubbele voorwaarde

21 Unterpertinger zaak, EHRM 24 november 1986, Series A, vol. 110, $\$ 31$.

22 Kostovski zaak, EHRM 20 november 1989, Series A, vol. 166, \$ 41. In de Delta zaak gebruikt het Hof een gelijkluidende overweging, zie EHRM 19 december 1990, Scries A, vol. 191, $\$ 36$.

23 Windisch zaak, EHRM 27 september 1990, Series A, vol. 186, § 26.

24 Delta zaak, EHRM 19 december 1990, Series A, vol. 191, Opinion of the Commission, $\$ 40$. 
moet worden gelezen: ten eerste dat de uitzondering op de hoofdregel is gerechtvaardigd en ten tweede dat in de uitzonderingssituatie de rechten van de verdachte voldoende zijn gewaarborgd. Toch is er een belangrijk argument voorhanden, dat pleit vóór deze ruime interpretatie van de woorden van het Hof.

Dit argument luidt dat het uitsluitend stellen van de tweede voorwaarde tot gevolg heeft dat van de hoofdregel niet veel over blijft. Het zwaartepunt van het strafproces zou kunnen verschuiven van het onderzoek ter terechtzitting naar het vooronderzoek. Indien de rechten van de verdachte in voldoende mate zijn gerespecteerd, mag voor het bewijs gebruik worden gemaakt van de door de politie dan wel de rechter-commissaris gedurende het vooronderzoek opgetekende verklaringen van getuigen. Deze enge opvatting zou in strijd zijn met het in de Colozza ${ }^{2}$ en de Barberà c.s. ${ }^{20}$ zaak benadrukte en reeds in de tekst van 6 lid 1 EVRM tot uitdrukking komende recht van de verdachte "to have his case heard in his presence by a tribunal" ${ }^{\text {w? }}$. Bovendien zou een dergelijke enge opvatting een miskenning betekenen van het recht van de verdachte op een "public hearing"zs.

Daarnaast zijn er in de uitspraken van het Hof ook wel meer directe aanwijzingen te vinden die lijken te wijzen op het stellen van de dubbele voorwaarde. Zo is er bijvoorbeeld de overweging die het Hof in de Unterpertinger zaak wijdt aan het verschoningsrecht van de getuige, als gevolg waarvan deze niet ter zitting kon worden ondervraagd:

\section{Collozza zaak, EHRM 12 februari 1985, Scries A, vol. 89, $\$ 27$ en 32.}

26 Barberà, Messegué en Jabardo zaak, EHRM 23 september 1987, Series A, vol. 146, \& 78.

27 Ik ga er daarbij vanuit dat de door het verdrag beschermde rechten zodanig moeten worden uitgelegd dat de met die rechten beoogde docleinden ook werkelijk bereikt worden. Zie Tyrer zaak, EHRM 25 april 1978, Series A, vol. 26, § 87. Zie hierover ook J.D. den Hartog, a.w., p. 38 en 39.

28 Zie in dit verband de Jan- $\AA$ ke Andersson zaak, EHRM 29 oktober 1991, Series A, vol. 212-B, $\$ 24$ en 27: "(..) In support of this opinion the Commission observed that the accused's right to a public hearing was not only an additional guarantee that an endeavour would be made to establish the truth but also helped to ensure that he was satisfied that his case was being determined by a tribunal, the independence and impartiality of which he could verify. Furthermore, the Commission considered that this right followed from the object and purpose of Article 6 taken as a whole; in particular, the rights contained in sub-paragraphs (c) and (d) of paragraph 3 of Article 6 to defend oneself in person and to examine or have examined witnesses could not be exercised without the accused being present. In this context it also recalled that the guarantee of a fair and public hearing in Article $6 \S 1$ of the Convention was one of the fundamental principles of any democratic society and that by rendering the administration of justice visible publicity contributed to the maintenance of confidence in the administration of justice; in addition, the public nature of the hearings, where issues of guilt and innocence were determined, ensured that the public was duly informed and that the legal process was publicly observable." (.) "The court fully recognises the value attaching to the publicity of legal proceedings for reasons such as those indicated by the Commission."

Zie ook: Axen zaak, EHRM 8 december 1983, Series A, vol. 72; Ekbatani zaak, EHRM 26 mei 1988, Series A, vol. 134; Helmers zaak, EHRM 29 oktober 1991, Series A, vol. 212-A; Fcjde zaak, EHRM 29 oktober 1991, Series A, vol. 212-C. 
"As such, the provision manifestly is not incompatible with Article $6 \S \S 1$ and 3 (d) of the Convention: it makes allowance for the special problems that may be entailed by a confrontation between someone "charged with a criminal offence" and a witness from his own family and is calculated to protect such a witness by avoiding his being put in a moral dilemma; furthermore there are comparable provisions in the domestic law of serveral member States of the Council of Europe. While the trial court and then the Court of Appeal were thus unable to hear evidence from Mrs. Unterpertinger and Mrs. Tappeiner, they had, on the other hand been obliged, to have the women's statements to the police read out when the prosecution so requested. ${ }^{\text {ns }}$

Deze overweging van het Hof kan worden uitgelegd als een controle van de rechtvaardiging die vereist is voor een legitieme inbreuk op de hoofdregel.

Een andere aanwijzing voor het stellen van de dubbele voorwaarde lijkt het Hof de geven in de Isgrò zaak. In deze uitspraak wordt overwogen dat Italiaanse autoriteiten zich voldoende maar helaas tevergeefse moeite hebben getroost om de getuige, ten aanzien waavan de verdachte ook al in het vooronderzoek de gelegenheid had gehad om deze te ondervragen, op te sporen ten einde zijn verschijning ter zitting te bewerkstelligen ${ }^{30}$.

Maar er zijn ook uitspraken aan te wijzen waarin het Hof geen afzonderlijke controle lijkt uit te oefenen op de noodzaak om van de hoofdregel af te wijken ${ }^{31}$. In de Kostovski ${ }^{32}$ en Windisch ${ }^{3}$ zaak bijvoorbeeld blijft het Hof niet expiciet stilstaan bij de vraag of het garanderen van anonimiteit aan getuigen in overeenstemming is met het verdrag. Het Hof gaat direct over tot de controle van de tweede voorwaarde, namelijk of gegeven het feit dat de getuigen niet ter zitting konden worden ondervraagd zodat dientengevolge alleen hun gereproduceerde verklaringen uit het vooronderzoek voor het bewijs konden worden gebruikt, de rechten van de verdediging in voldoende mate in acht zijn genomen ${ }^{3}$.

31 Zie ook de Saïdi zaak, EHRM 20 september 1993, Series A, vol. 261-C.

34 Wel besteedt het Hof in beide uitspraken aandacht aan de vraag of de inbreuken op het rechten van de verdediging in de uitzonderingssituatie gerechtvaardigd konden worden door hetgeen van overheidswege werd benadrukt. In de Kostowki zaak bijvoorbecld verdedigde de regering het gebruik van de anonieme getuigenverklaringen - en daarmee de inbreuken op de verdedigingsrechten in de uitzonderingssituatic - door de groei in bedreigingen van potentiële getuigen en in de Windisch zaak door crop te wijzen dat de medewerking van het publick van groot belang is bij de bestrijding van de criminaliteit. Het Hof overwoog dat: "The right to a fair administration holds so prominent a place in a democratic society that it cannot be sacrificed to expediency. (..) The use of this evidence involved limitations on the rights of the defence which were irreconcilable with the guarantees contained in Article 6." Zie Kostovski zaak, EHRM 20 november 1989, Series A, vol. 166, $\$ 44$ en Windisch zaak, EHRM 27 september 1990, Series A, vol. 186, $\$ \$ 30$ en 31. Zie ook Saìdi zaak, EHRM 20 september 1993, Series A, vol. 261-C, $\$ 44$ : "The court is fully aware of the undeniable 
Het feit dat het Hof in verschillende uitspraken geen overwegingen wijdt aan de noodzaak om van de hoofdregel af te wijken, betekent echter nog niet dat het die noodzaak niet impliciet toch wel aanvaardt. Een mogelijke verklaring is ook dat het Hof uit een oogpunt van zijn taakopvatting - om aan te geven of de geboden procedure in dit geval fair is geweest en niet of de geboden procedure in zijn algemeenheid fair is - met de controle van de tweede voorwaarde begint. Is immers aan die voorwaarde niet voldaan dan hoeft de eerste voorwaarde niet meer aan de orde te komen.

Maar dit doet er niet aan af, dat uit de verschillende casusgebonden overwegingen van het Hof niet met zekerheid kan worden afgeleid dat het Hof de dubbele voorwaarde stelt. Het doorslaggevende argument blijft daarom dat het Hof naast de eis dat de rechten van de verdachte in de uitzonderingssituatie worden gerespecteerd, de eis van de noodzakelijkheid om van de hoofdregel af te wijken wel moet stellen omdat anders van de hoofdregel niet veel over blijft. Het enkel stellen van de voorwaarde dat de rechten van de verdediging met betrekking tot het horen van getuigen in acht worden genomen is bovendien in strijd met het eveneens aan de verdachte toegekende recht om zijn zaak te laten beoordelen door de zittingsrechter ${ }^{3 s}$.

\subsubsection{Conclusie}

Uit de Barberà c.s. zaak kunnen geen harde conclusies worden getrokken over de noodzakelijkheid van de presentatie van stukken van overtuiging ter zitting voor de garantie van een 'fair trial' aan de verdachte. Welke rol de overige bijzondere omstandigheden van het geval hebben gespecld bij het uiteindelijke oordeel van het Hof dat de verdachten geen 'tair trial' ten deel is gevallen, is onduidalijk. Wel kan worden vastgesteld dat de omissie om de stukken van overtuiging ter zitting

difficulties of the fight against drug-trafficking - in particular with regard to obtaining and producing evidence - and of the ravages caused to society by the drug problem, but such considerations cannot justify restricting to this extent the rights of the defence of "everyone charged with a criminal offence".

35 Zic ook G.P.M.F. Mols, Over het onmiddellijkheidsbeginsel in strafzaken, In: Rechtsbeginselen, themanummer AA 1991, p. 170: "Uit de formulering van het Hof dat het bewijs in beginsel ter zitting moet worden geproduceerd moet worden afgeleid dat de realisering van het onmiddellijkheidsbeginsel door het Hof wordt gezien als een bovengrens, dat daaronder ruimte is voor een invulling die niet volledig ain het beginsel van onmiddellijkheid beantwoordt en dat deze afwijkingen zijn toegestaan totdat de grens wordt bereikt waarbij niet meer kan worden gezegd dat het proces in zijn totaliteit bezien nog fair was. (..) Daarmee dringt zich de vraag op of het is toegestaan om zonder noodzaak onder de bovengrens van het Hof te duiken. De rechtspraak van het Hof geeft geen eenduidig uitsluitsel maar biedt wel aanknopingspunten voor een ontkennend antwoord. Het onmiddellijkheidsbeginsel dient ook volgens het Hof een behoorlijke rechtspleging. Dat is een algemeen belang dat in een democratische rechtsstaat dient te worden gerespecteerd. Dit impliceert dat de door het Hof gegeven algemene norm telkens en in principe moet worden gehaald tenzij zich bijzondere omstandigheden voordoen die daaraan in de weg staan." 
te presenteren terwijl daarvan voor het bewijs wel gebruik is gemaakt, heeft bijgedragen aan het negatieve oordeel van het Hof.

Wat betreft het gebruik van gereproduceerde getuigenverklaringen ${ }^{36}$ uit het vooronderzoek voor het bewijs kan uit de algemene overwegingen van het Hof worden afgeleid dat dit onder voorwaarden niet in strijd is met het recht van de verdachte op een 'fair trial'. Die voorwaarden zijn tweeërlei. Allereerst dient het gebruik van de gereproduceerde getuigenverklaringen uit het vooronderzoek noodzakelijk te zijn, hetgeen wil zeggen dat de getuige om gerechtvaardigde redenen niet ter zitting kan verschijnen. Daarnaast dienen bij het gebruik van gereproduceerde getuigenverklaringen uit het vooronderzoek de rechten van de verdachten in voldoende mate worden gerespecteerd.

3.2.4 Uitzonderingen op de hoofdregel mits de verdachte een adequate en gepaste gelegenheid heeft gehad de getuige te (doen) ondervragen tijdens het vooronderzoek

Een procedure in strijd met het uitgangspunt dat alle bewijs ter terechtzitting in aanwezigheid van de verdachte moet worden geproduceerd, kan toch in overeenstemming zijn met art. 6 lid 1 en 3 (d) EVRM. Daarvoor is dan wel noodzakelijk dat in zo'n situatie de rechten van de verdediging zijn gerespecteerd. Dit betekent volgens constante jurisprudentie van het $\mathrm{EHRM}^{37}$ dat: "As a general rule, paragraphs 3(d) and 1 of Article 6 require that the defendant be given an adequate and proper opportunity to challenge and question a witness against him, either when he makes his statements or at a later stage." Maar wanneer is er sprake van een "adequate and proper opportuni$t y$ "? Veel hangt af van de bijzondere omstandigheden van het geval. Een drietal omstandigheden die volgens de jurisprudentie van de ECRM en het EHRM bij het antwoord op deze vraag een rol kunnen spelen, worden nader bekeken. Deze omstandigheden zijn:

a. de vraag of de verdediging op de hoogte moet zijn van de identiteit van de getuige;

b. de vraag of daarbij een raadsman aanwezig is geweest en

c. de vraag welke rol het bewijs heeft gespeeld bij de bewezenverklaring.

36 Om precies te zijn gaat het hier om schriftelijke verklaringen van horen zeggen, opgetekend door een opsporingsambtenaar of een rechter-commissaris.

37 Zie Unterpertinger zaak, EHRM 24 november 1986, Series A, vol. 110, \$31; Baraberà, Messegué en Jabardo zaak, EHRM 6 december 1988, Series A, vol. 146, $\$ 86$; Kostovski zaak, EHRM 20 november 1989, Series A, vol. 166, $\$ 41$; Windisch zaak, EHRM 27 september 1990, Series A, vol. 186, § 26; Delta zaak, EHRM 19 december 1990, Series A, vol. 191, \$ 36; Isgrò zaak, EHRM 19 februari 1991, Scries A, vol. 194-A, \$ 34; Asch zaak, EHRM 26 april 1991, Series A, vol. 203, §27; Lüdi zaak, EHRM 15 juni 1992, Series A, vol. 238, §47. 


\subsubsection{Onbekendheid met de identiteit van de getuige}

Onder andere de Kostovski zaak biedt inzicht in het belang van de bekendheid van de verdediging met de identiteit van de getuige voor een "adequatc and proper opportunity" die de verdachte moet worden geboden om een getuige te (doen) ondervragen. Het Hof oordeelde in dit geval dat de verdediging geen adequate en passende gelegenheid was geboden om de getuigen te (doen) ondervragen, van wie de dour de politie dan wel de optredende rechters-commissarissen opgetekende verklaringen voor het bewijs waren gebruikt. Het ging hier om beweerdelijk bedreigde getuigen, waarvan de identiteit geheim was gehouden. Het ondervragingsrecht van de verdediging was beperkt tot de gelegenheid, om aan één van die getuigen gedurende het vooronderzoek schriftelijke vragen te stellen via de rechter-commissaris en de gelegenheid om een opsporingsambtenaar en de beide rechters-commissarissen die de getuigenverhoren gedurende het vooronderzoek hadden afgenomen ter zitting te ondervragen. Het Hof stelde echter vast dat de aard en de reikwijdte van de vragen die de verdediging in zulke omstandigheden zou kunnen stellen aanzienlijk was heperkt door de beslissing om de anonimiteit van de getuigen te waarborgen. Het Hof overwoog:

"If the defence is unaware of the person it seeks to question, it may be deprived of the very particulars enabling it to demonstrate that he or she is prejudiced, hostile or unreliable. Testimony or other declarations inculpating an accused may well be designedly unthruthful or simply erroneous and the defence will scarcely be able to bring this to light if it lacks the information permitting it to test the author's reliability or cast doubt on his credibility. The dangers inherent in such a situation are obvious. ${ }^{138}$

In de Windisch zaak waar voor het bewijs ook gebruik werd gemaakt van twee anonieme getuigenverklaringen, drukt het Hof zich nog stelliger uit over de belemmering die de onbekendheid met de identiteit van de getuige met zich brengt voor het ondervragingsrecht: "Being unaware of their identity, the defence was confronted with an almost insurmountable handicap: it was deprived of the necessany information permitting it to test the witnesses' reliability or cast doubt on their credibility. ${ }^{100}$

In de Lüdi zaak echter nuanceert het Hof zijn oordeel dat de bekendheid van de verdediging met de identiteit van de getuige voorwaarde vormt voor een adequate en passende uitoefening van het ondervragingsrecht. In deze zaak ging het onder andere ${ }^{40}$ om een getuige in de hoedanigheid van een undercover-agent, die aan de verdachte bekend was onder de naam Toni. Het bewijs in deze zaak was vooral

38 Kostovski zaak, EHRM 20 november 1989, Series A, vol. 166, $\$ 42$.

39 Windisch zaak, EHRM 27 september 1990, Series A, vol. 186, $\$ 28$.

40 In de Lüdi zaak komt ook de vraag aan de orde in hoeverre de inzet van de undercover-agent en de telefoontap op het moment dat er nog geen sprake was van een gepleegd strafbaar feit, in overeenstemming kan worden geacht met art. 8 EVRM, dat het recht op 'private life' regelt. 
gebaseerd op het proces-verbaal opgemaakt door de undercover-agent - het betreft hier een schriftelijke getuigenverklaring - en de tapjournaals van de telefoongesprekken van deze met de verdachte. Noch in eerste aanleg, noch in hoger beroep werd de undercover-agent, die de verdachte vijf maal had ontmoet, ter zitting gedagvaard omdat zijn anonimiteit, met het oog op zijn mogelijk nieuwe inzetbaarheid als infiltrant, gewaarborgd diende te worden. Het Hof oordeelt:

"The court finds that the present case can be distinguished from the Kostovski $v$. the Netherlands and the Windisch v. Austria cases, where the impugned convictions were based on statements made by anonymous witnesses. In this case the person in question was a sworn police officer whose function was known to the investigating judge. Moreover, the applicant knew the said agent, if not by his real identity, at least by his physical appearance, as a result of having met him on five occasions. However, neither the investigating judge nor the trial courts were able or willing to hear Toni as a witness and carry out a confrontation which would enable Toni's statements to be contrasted with Mr Lüdi's allegations; moreover, neither Mr Lüdi nor his counsel had at any time during the proceedings an opportunity to question him and cast doubt on his credibility. Yet it would have been possible to do this in a way which took into account the legitimate interest of the police authorities in a drug trafficking case in preventing the anonymity of their agent, so that they could protect him and also make use of him again in the future. In short, the rights of the defence were restricted to such an extent that the applicant did not have a fair trial. ${ }^{\text {mal }}$

Deze undercover-agent kon niet worden beschouwd als een anonieme getuige in de strikte zin des woords. Tenwijl in de Kostovski en de Windisch zaak de bekendheid met de identiteit van de getuigen noodzakelijke informatie vormde om de getuige adequaat te kunnen ondervragen, was in dit geval de bekendheid met de wáre identiteit van de getuige daartoe niet onontbeerlijk. Omdat de verdachte de undercoveragent reeds kende van gezicht, had hij ook kunnen controleren of hij met de juiste persoon geconfronteerd werd en had hij hem gericht kunnen (doen) ondervragen. $\mathrm{Nu}$ hem daartoe de gelegenheid niet was geboden, moest worden vastgesteld dat de verdachte geen 'fair trial' ten deel was gevallen ${ }^{62}$.

41 Lüdi zaak, EHRM 15 juni 1992, Series A, vol. 238, \$\$ 49 en 50.

42 Zie ook L.C.M. Meijers, Over Lüdi tegen Zwitserland, EHRM 15 juni 1992, D\& D 1994, p. 276 en 277 , die uit deze zaak afleidt dat "verklaringen van een anonieme politiefunctionaris" bij de bewijsvocring een belangrijk gewicht in de schaal mogen leggen, mits het recht van de verdachte op tegenspraak in enige fase van de procedure is verwezenlijkt. Voor dit laatste is niet noodzakelijk dat fegenover de verdediging de anonimiteit van de getuige (in de ruime zin van het woord) wordt

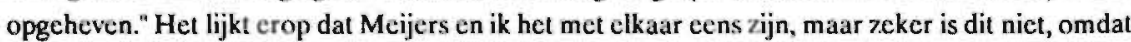
onduidelijk is wat Meijers bedoeld met 'anonimiteit in ruime zin'. Bovendien denk ik dat in het kader van de Lüdi zaak beter nict kan worden gesproken van "verklaringen van een anonieme politiefunctionaris". De crux van de zaak is dat verklaringen moeten zijn terug te voeren tot de oorspronkelijke zegsman zodat de verdediging deze oorspronkelijke zegsman daarover gericht kan ondervragen. Slechts in die zin is de identiteit van de getuige "necessary information" (vgl. de Kostovski en Windisch zaak). Een anonieme getuigenverklaring is nu juist een verklaring die 


\subsection{Compensatie}

In de vorige paragraaf werd duidelijk dat de bekendheid van de verdediging met de identiteit van de getuige in de regel (zie Lüdi zaak) voorwaarde vormt voor een adequate en passende gelegenheid tot ondervraging van een getuige. Maar daarmee is de zaak niet afgedaan. Uit de Kostovski zaak ${ }^{43}$ lijkt immers op het eerste gezicht tevens voort te vloeien dat de belemmering van het ondervragingsrecht van de verdachte die veroorzaakt wordt door de onbekendheid met de identiteit van de getuige, onder omstandigheden gecompenseerd kan worden door het optreden van de rechterlijke autoriteiten in de desbetreffende $z^{2 a k^{*}}$. De uitspraak biedt echter evenzeer basis voor de stelling dat een dergelijke compensatie in het geheel niet mogelijk is $^{45}$. Het Hof oordeelde weliswaar dat van een voldoende compensatie geen sprake was, maar liet zich strikt genomen niet uit over de vraag of een dergelijke compensatie wel tot de mogelijkheden behoort. Het argument dat het Hof over compensatie niet zou spreken, indien deze in het geheel niet zou kunnen bestaan, is niet overtuigend. Het is heel goed voorstelbaar dat het Hof met de betreffende overweging reageert op het verweer van de Nederlandse regering dat de belemmering van het ondervragingrecht naar vermogen door het optreden van de rechterlijke autoriteiten werd gecompenseerd. Deze voorstelling van zaken wordt in ieder geval gesteund door twee omstandigheden. Allereerst kan worden gewezen op het feit dat het Hof in de betreffende overweging expliciet stilstaat bij 'de behoedzaamheid' die de rechters hebben betracht bij de waardering van het schriftelijke (anonieme) getuigenbewijs uit het vooronderzoek. In de Nederlandse jurisprudentie is de waarborg tegen het al te voortvarend gebruik van anonieme getuigenverklaringen gezocht in de 'behoed-

niet is terug te voeren tot de oorspronkclijke zegsiman.

Zic ook Corstens (1993), a.w., p. 621 en 622, die meent dat uit de Lüdi zaak kan worden afgeleid dat de cis dat een veroordeling niet in hoofdzaak op anonieme getuigenverklaringen mag be rusten ten aanzien van politiefunctionarissen die als anonieme getuigen optreden, enigszins mag worden afgerwakt.

43 Kostovski zaak, EHRM 20 november 1989 , Scries A, vol. 166, § 43: "In these circumstances it cannot be said that the handicaps under which the defence laboured were counterbalanced by the procedures followed by the judicial authorities".

Zo: E.P. Von Brucken Fock, Anonieme getuige exit?, NJB 1990, p. $301 \mathrm{t} / \mathrm{m} 309 \mathrm{en}$ T.M. Schalken, Anonieme getuige en strafvorderlijke logistiek, NJB 1990, p. $81 / \mathrm{m} \mathrm{13}$, in het bijzonder p. 12. Zie ook T.M. Schalken in zijn annotatic onder het zgn. Finkensieper-arrest: HR 1 oktober 1991, NJ 1992,197 , die kennelijk van mening is dat de compensatie dic kan worden geboden door het optreden van de rechterlijke autoriteiten niet alleen beperkt is tot de belemmering van het ondervragingsrecht van de verdachte die veroorzakt werd door de onbekendheid van de verdediging met de identiteit van de getuige, maar ook geldt voor andere belemmeringen van het ondervragingsrecht. Zie: A. Beyer, Kostovski treft anonieme getuige in het hart, Recht en Kritick 1990, p. $254 \mathrm{t} / \mathrm{m}$ 256; P.M. Frielink, De anonieme getuige na Kostovski, D\&D 1990, p. 4501/m 459; G.P.M.F. Mols, Annotatic Kostovski uitspraak, Advocatenblad 1989, p. 685 t/m 690; Ties Prakken, Het OM en de anonieme getuige, NJB 1990, p. 310 1/m 312; J.F. Nijboer, Kostovski en de inquisitoire stijl van procederen, NJB 1990, p. 595. 
zaamheid' waarmee de rechter met dit bewijs dient om te gaan ${ }^{+6}$. Ten tweede is het opvallend, dat het Hof in de Windisch zaak, waarin een soortgelijke problematiek speelde, over compensatie niet meer rept. Weliswaar wordt in de Windisch zaak naar de Kostovski zaak verwezen, maar deze overweging kan heel goed ten overvloede zijn bedoeld ${ }^{47}$.

Maar zelfs al zou van compensatie sprake kunnen zijn, dan nog kan uị de Kostovski zaak niet worden afgeleid waaruit die compensatie dient te bestaan ${ }^{48}$. Een en ander zal afhangen van de bijzondere omstandigheden van het geval, maar dat aan die compensatie dan hoge eisen moeten worden gesteld is duidelijk. Het gaat immers om een compensatie voor wat het Hof bestempelt als een "almost insumountable handicap".

In de Kostovski zaak was in ieder geval géén sprake van een voldoende compensatie - voor de belemmering van het ondervragingsrecht die werd veroorzaakt door de onbekendheid met de identiteit van de getuigen - door het optreden van de rechterlijke autoriteiten, omdat":

a. ook de zittingsrechters de getuigen niet hebben kunnen waarnemen tijdens hun verhoor. Op grond van hun eigen waarneming hadden zij mogelijk enige conclusies kunnen trekken over de betrouwbaarheid van deze getuigen. De verklaringen van een opsporingsambtenaar en beide betrokken rechters-commissarissen over hun betrouwbaarheid die ter zitting werden afgelegd konden niet worden beschouwd als een passende vervanging voor de direkte waarneming van de getuigen door de rechters. Ook de behoedzaamheid waarmee de zittingsrechters het schriftelijke (anonieme) getuigenbewijs op zijn waarde hebben geschat kon niet opwegen tegen de eventuele controle die uitgaat van de direkte waarneming van de getuigen tijdens hun verhoor.

b. ook de rechters-commissarissen, die één van de anonieme getuigen had verhoord niet op de hoogte waren van diens identiteit.

46 Zie ook A.HJ. Swart in zijn annotatie bij de Kostovski uitspraak, AA, 1990, p. 322. Ook volgens Swart is de overweging van het $H$ of over de rechtcrlijke behocdzaam heid een rechtstreekse reactie op de vaste rechtspraak van de Hoge Raad.

47 Zie: Windisch zaak, EHRM 27 september 1990, Series A, vol. 186, \$29: "In addition, the trial court, which was also unaware of the two women's identity, was prevented from observing their demeanour under questioning and thus forming its own impression of their reliability (see the above-mentioned Kostovski judgment, Series $A$, vol. 166, p. 20, $\$ 43$ ). The police officers' evidence on this point at the hearings cannot be regarded as a proper substitute for direct observation."

48 Zie anders: E.P. Von Brucken Fock (1990), a.w., p. $301 \mathrm{t} / \mathrm{m} 309 \mathrm{cn}$ T.M. Schalken (1990), a.w., p. $8 \mathrm{t} / \mathrm{m}$ 13. Zic ook de reactic daarop van Ties Prakken (1990), a.w., p. 311: "Het is nooit erg sterk om conclusies te verbinden aan wat in een rechterlijke uitspraak niet staat, maar tegen het licht van deze vaste rechtspraaktechniek van het Europese Hof is het zeker onverantwoord iets af te leiden uit het achterwege gebleven zijn van een uitspraak over het gebruik voor het bewijs van anonieme getuigenverklaringen in het algemeen."

49 Zie Kostovski zaak, EHRM 20 november 1989, Series A, vol. 166, \$ 43. 
Bekendheid van de verdediging met de identiteit van de getuige vormt een belangrijke voorwaarde voor een adequate en gepaste gelegenheid die de verdachte moet worden geboden om de hem belastende getuige te ondervragen gedurende enige fase van het onderzoek. Onder omstandigheden echter kan de bekendheid van de verdediging met een aangenomen identiteit voldoende zijn voor een deugdelijke uitoefening van zijn ondervragingsrecht.

Dat de belemmering van het ondervragingsrecht die wordt veroorzaakt door de onbekendheid van de verdediging met de identiteit van de getuige onder omstandigheiden gecompenseerd kan worden door het optreden van de rechterlijke autoriteiten, is onwaarschijnlijk. Maar al zou worden aangenomen dat compensatie mogelijk is, dan kan uit de Kostovski en Windisch zaak niet worden afgeleid waanit die compensatie moet bestaan. Dat daaraan hoge eisen moeten worden gesteld is duidelijk, nu deze compensatie moet opwegen tegen "an almost insurmountable handicap".

\subsubsection{Aanwezigheid van de raadsman}

Eist een adequate en passende gelegenheid om de belastende getuige in enige fase van het proces te kunnen ondervragen, dat de verdachte daarbij steeds wordt bijgestaan door zijn raadsman? In de Isgrò zaak heeft het EHRM uitgemaakt dat de aanwezigheid van de raadsman bij de confrontatie tussen de verdachte en de hem belastende getuige onder omstandigheden niet onontbeerlijk behoeft te zijn om de garanties die art. 6 lid $3(\mathrm{~d})$ de verdachte biedt, in voldoende mate te genieten ${ }^{5}$ In deze zaak kwam het Hof tot het oordeel dat de verdachte wel een eerlijk proces had gehad. Diverse bijzondere omstandigheden hebben bij dit oordeel een rol gespeeld ${ }^{51}$.

Zo ging het hier om door de rechter-commissaris opgetekende verklaringen van een getuige die niet anoniem was. Verder was de verdachte zonder zijn raadsman bij de rechter-commissaris tijdens het vooronderzoek met deze getuige geconfronteerd. De verdachte heeft toen aan de getuige rechtstreeks vragen kunnen stellen, zijn verklaringen ter discussie kunnen stellen en zijn geloofwaardigheid in twijfel kunnen trekken. Bovendien was de raadsman in de gelegenheid om ter zitting zijn bezwaren te uiten tegen deze getuige, waarvan hij de identiteit en de verklaringen kende. Daarnaast overwoog het Hof dat de zittingsrechters zich voldoende moeite hadden getroost om de getuige alsnog op de zitting te laten verschijnen, echter zonder resultaat. De getuige bleek onvindbaar. Met deze laatste overweging benadrukt het Hof wederom de hoofdregel, dat alle bewijs in beginsel op zitting geproduceerd dient te worden.

50 Isgro zaak, EHRM 19 februari 1991, Series A, vol. 194-A, \$36. Zie ook: C.J.C.F. Fijnaut, Officicr van Justitie versus Bende van de Miljardair, Arnhem 1993, p. 65.

51 Zie Isgrd zaak, EHRM 19 februari 1991, Series A, vol. 194-A, \$\$ 35 en 36. 
In de Isgrò zaak was voor het oordeel van het Hof tevens van belang dat de verdachte niet enkel was veroordeeld op basis van de betreffende gereproduceerde getuigenverklaring. De beslissing was mede gebaseerd op andere getuigenverklaringen en het gedrag van de verdachte tijdens het vooronderzoek en de zitting ${ }^{22}$.

De rol die het bewijs voor de bewezenverklaring heeft gespeeld, is voor het Hof van belang bij de beantwoording van de vraag of de verdedigingsrechten van de verdachte in voldoende mate in acht zijn genomen, wanneer dit bewijs niet ter zitting werd geproduceerd. Al in de Unterpertinger zaak, de eerste belangrijke uitspraak van het Hof over het ondervragingsrecht van de verdachte, besteedde het Hof hieraan uitdrukkelijk aandacht ${ }^{5}$. In die zaak vormden de door de politie opgetekende verklaringen van de getuigen, ten aanzien waarvan de verdachte niet in de gelegenheid was geweest deze te (doen) ondervragen, weliswaar niet het enige bewijs maar wel het belangrijkste bewijs voor de veroordeling van de verdachte ${ }^{54}$.

In de Kostovski zaak overwoog het Hof dat de veroordeling van de verdachte "to a decisive extent" was gebaseerd op anonieme verklaringen, dat wil zeggen door de politie dan wel de rechter-commissaris opgetekende verklaringen van getuigen ten aanzien waarvan de verdachte geen adequate en passende gelegenheid heeft gehad deze te ondervragen ${ }^{3 s}$.

In de Windisch zaak oordeelde het Hof dat de rechter "to a lange extent" vertrouwde op het anonieme getuigenbewijs, dus gereproduceerde verklaringen van getuigen ten aanzien waarvan de verdachte geen adequate en passende gelegenheid was geboden deze te ondervragen ${ }^{\$}$.

Ook de veroordeling van de verdachte in de Delta zaak werd "decisively at first instance and on appeal, as the file contained no other evidence" gebaseerd op de door de politie opgetekende verklaringen van twee getuigen, ten aanzien waarvan de verdachte niet in de gelegenheid was deze te ondervragen. Deze omstandigheid leidde tot de slotsom dat "Mr Delta did not receive a fair trial"s.

Belangrijk is in dit verband ook de uitspraak van het Hof in de Asch zaak. De casus in deze zaak vertoont gelijkenis met de situatie in de Unterpertinger zaak. Het ging hier om het gebruik van een door de politie tijdens het vooronderzoek opgetekende getuigenverklaring. De getuige die deze verklaring had afgelegd deed ter terechtzitting een beroep op het haar toekomende verschoningsrecht. De verdachte was in geen enkele fase van het proces in de gelegenheid gesteld deze belastende

52 Isgrò zaak, EHRM 19 februari 1991, Series A, vol. 194-A, § 35.

53 Zie hierover G.J.M. Corstens, Van cri de justice naar anonieme getuigenverklaring; 75 jaar de-auditujurisprudentic, In: NJ 1913-1988, Annotatoren kijken terug, Zwolle 1988, p. 39.

54 Unterpertinger zaak, EHRM 24 november 1986, Series A, vol. 110, 33 .

55 Kostovski zaak, EHRM 20 november 1989, Scries A, vol. 166, §44.

56 Windisch zaak, EHRM 27 september 1990, Series A, vol. 186, §31.

57 Delta zaak, EHRM 19 december 1990, Scries A, vol. 191, $\$ 37$. 
getuige te (doen) ondervragen. Toch heeft de nationale rechter volgens het Hof de veroordeling (mede) mogen baseren op haar door de politie opgetekende verkla-

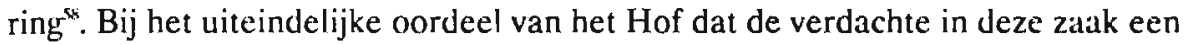
'fair trial' had gehad, speelde een aantal bijzondere omstandigheden mee. Zo werd de betreffende gereproduceerde getuigenverklaring bijvoorbeeld hevestigd door ander bewijs ${ }^{*}$. Daaronder bevond zich een wel ter terechtzitting in aanwezigheid van de verdachte afgelegde getuigenverklaring. Bovendien had de verdachte het hlijkbaar niet nodig gevonden zijn ondervragingsrecht uit te oefenen ten aanzien van deze wel ter zitting verschenen getuige ${ }^{60}$. Maar tenslotte overweegt het Hof ook nog dat: "Above all it is clear from the file that Mrs J.L. 's statements, as related by officer B., did not constitute the only item of evidence on which the first-instance court hased its decision. ${ }^{* 1}$ Er was voldoende ander bewijs ${ }^{* 2}$.

Ten slotte dient hier nog de uitspraak van het Hof in de Artner zaak te worden besproken. In deze zaak was ook sprake van door de politie dan wel de rechtercommissaris gedurende het vooronderzoek opgetekende verklaringen van een getuige die voor het bewijs werden gebruikt. De verdachte was niet in de gelegenheid geweest de betreffende getuige in enige fase van het proces te (doen) ondervragen. Dit was deels te wijten aan zijn eigen schuld, doordat hij tot drie maal toe geen gehoor had gegeven aan de uitnodiging zich te melden in verband met de vervolging die tegen hem was ingesteld ${ }^{63}$. Tegen de tijd dat hij was uitgeleverd en er een confrontatie tussen de getuige en de verdachte kon worden georganiseerd was inmiddels de getuige onvindbaar. De terechtzitting werd tweemaal aangehouden met de bedoeling de getuige op te sporen en ter zitting te horen. Deze pogingen leverden echter niets $\mathrm{op}^{64}$. Het Hof overwoog het volgende: "As it was impossible to secure Miss L.'s attendance at the hearing, it was open to the national court, subject to the rights of the defence being respected, to have regard to the statements obtained by the police and the investigating judge, in particular in view of the fact that it could consider those statements to

Asch zaak, EHRM 26 april 1991, Scries A, vol. 203, $\$ 28$.

59 Asch zaak, EHRM 26 april 1991, Series A, vol. 203, $\$ 28:(.$.$) , in particular in view of the fact that$ it could consider it to be corroborated by other evidence before it, (..)."

60 Asch zaak, EHRM 26 april 1991, Series A, vol. 203, $\S 29$.

61 Asch zaak, EHRM 26 april 1991, Scries A, vol. 203, $\$ 30$.

62 De rol die het bewijs speclt bij de veroordeling vormt een belangrijk aspect voor het antwoord op de vraag of de rechten en vrijheden van de verdachte in voldoende mate in acht zijn genomen. Dit blijkt ook uit de 'joint dissenting opinion' van de rechters Sir Vincent Evansi en Bernhardt in deze zaak. Zij zijn van mening dat de veroordeling van de klager hoofdzakelijk werd gebaseerd op de verklaring van de getuige, ten aanzien waarvan de verdachte niet in de gelegenheid was deze te (doen) ondervragen. De klager werd aldus veroordeeld op basis van getuigenbewijs ten aanzien waarvan zijn verdedigingsrechten op zodanige wijze waren beperkt dat hem geen eerlijk proces ten deel viel.

63 Artner 7aak, EHRM 28 augustus 1992, Seires A, vol. 242-A, \$§ 9 en 20.

64 Artner zaak, EHRM 28 augustus 1992, Series A, vol. 242-A, § 21. 
be corroborated by other evidence before it." ${ }^{\text {"ss }}$ (..) "It follows that Miss L.'s statements were not the only evidence on which the Regional Court based its finding. Accordingly, the fact that it was impossible to examine her at the hearing did not, in the circumstances of the case, infringe the rights of the defence to such an extent that it constituted a breach of paragrafhs 1 and 3(d) of Article 6, taken together.

Uit de aangehaalde zaken kan geen duidelijk antwoord worden afgeleid op de vraag wanneer een door de politie dan wel door de rechter-commissaris opgetekende verklaring van een getuige ten aanzien waarvan de verdachte niet in de gelegenheid is geweest deze te (doen) ondervragen, voor het bewijs mag worden gebruikt, zonder dat de verdedigingsrechten van de verdachte te zeer worden beperkt. In de Unterpertinger zaak was de veroordeling van de verdachte "mainly based on" dit soort verklaringen. In de Kostovski zaak berustte de veroordeling "to a decisive extent" op dergelijke verklaringen. In de Windisch zaak vertrouwde de rechter "to a lange extent" op dit soort verklaringen. In de Delta zaak gebruikt het Hof de term "decisively". In de Asch zaak was er sprake van dat dit bewijs "was not the only item of evidence" waarop de veroordeling werd gebaseerd. En ook in de Artner zaak ging het erom dat dit bewijs "was not the only evidence" waarop de veroordeling berustte. Lijkt het Hof in de eerste vier genoemde zaken een kwalitatieve norm te hanteren; in de laatste twee zaken lijkt eerder sprake van een kwantitatieve norm. De norm die het Hof stelt, lijkt gaandeweg te versoepelen: het feit dat er meer bewijs is, sluit niet uit dat het gereproduceerde bewijs het belangrijkste bewijs vormt. Betekent dit dat een door de politie dan wel de rechter-commissaris opgetekende verklaring van een getuige, ten aanzien van wie de verdachte niet in de gelegenheid is geweest deze te (doen) ondervragen, gewoon voor het bewijs mag worden gebruikt, indien deze verklaring maar bevestigd wordt door ander bewijs ten aanzien waarvan de verdedigingsrechten van de verdachte wel in acht zijn genomen? Afgezien nog van de omstandigheid dat niet duidelijk is wat wordt bedoeld met de vereiste bevestiging door ander bewijs is zo'n verstrekkende conclusie is niet zonder gevaar. Welke invloed de overige bijzondere omstandigheden van het geval op de uitspraken van de Asch en Artner zaak hebben gespeeld is onduidelijk.

\subsubsection{Conclusie}

Volgens de rechtspraak van het EHRM en de ECRM is het gebruik van gereproduceerd getuigenbewijs niet per definitie in strijd met art. 6 EVRM. Wil strijd met art. 6 EVRM worden voorkomen dan betekent dit dat in beginsel aan de verdachte

65 Artner zaak, EHRM 28 augustus 1992, Series A, vol. 242-A, $\$ 22$.

66 Artner zaak, EHRM 28 augustus 1992, Series A, vol. 242-A, $\$ 24$. Zie cok de dissenting opinions van vier rechters in deze zalak. Zij zijn van mening dat de schriftelijke getuigenverklaringen van de aangeefster misschien niet het enige bewijs voor de veroordeling vormde, maar toch zonder twijfel het belangrijkste bewijs. 
een adequate en passende gelegenheid moet zijn geboden om de betreffende getuige te (doen) ondervragen. Voor een adequate en passende gelegenheid om de getuige te ondervragen is in zijn algemeenheid vereist dat de verdediging op de hoogte is van de identiteit van de getuige. Onder omstandigheden is voor een adequate en passende gelegenheid tot ondervraging voldoende dat de verdediging op de hoogte is van een aangenomen identiteit van de getuige. Voor een adequate en passende gelegenheid tot ondervraging is daarentegen niet onontbeerlijk dat de verdachte door een raadsman wordt bijgestaan.

Onder omstandigheden vormt het ontbreken van een adequate en passende gelegenheid tot ondervraging van de getuige, waarvan de verklaring - in de door een opsporingsambtenaar of rechter-commissaris opgetekende vorm - voor het bewijs wordt gebruikt, toch geen inbreuk op art. 6 EVRM. Daarvoor is in ieder geval vereist dat het gereproduceerde getuigenbewijs niet het enige bewijs vormt en dat dit gereproduceerde getuigenbewijs wordt bevestigd door ander bewijs ten aanzien waarvan de verdedigingsrechten van de verdachte wel in acht zijn genomen. Wat dit precies betekent, is echter niet duidelijk.

\subsection{Ontvankelijkheid van de klager en verdeling van verantwoordelijkheden}

De hoofdregel die uit de Europese jurisprudentie inzake het horen van getuigen à charge kan worden afgeleid, luidt dat alle bewijs in beginsel ten overstaan van de rechter en in aanwezigheid van de verdachte ter terechtzitting dient te worden geproduceerd. Op deze regel zijn weliswaar uitzonderingen mogelijk maar daarbij dienen de rechten van de verdediging in voldoende mate gerespecteerd te worden. Daaruit vloeit in beginsel voort dat de verdachte gedurende enige fase van het onderzoek een adequate en gepaste mogelijkheid moet zijn geboden om de hem belastende getuige te (doen) ondervragen.

Maar betekent deze hoofdregel, inclusief de nuanceringen die daarop zijn aangebracht, dat de rechter zijn oordeel enkel mag baseren op direkt bewijs, wanneer er geen rechtvaardigende omstandigheden aanwezig zijn om van de hoofdregel af te wijken? Dit is een interessante vraag, waarop het antwoord enige uitweiding vereist. Strikt genomen betreft de aangesneden kwestie namelijk het probleem bij wie de verantwoordelijkheid ligt voor de 'fairness' van de geboden procedure. In dit verband is de uitspraak van het EHRM in de Cardot zaak ${ }^{\text {77 }}$ van belang. Uit deze zaak wordt wel afgeleid dat wanneer de verdachte noch zijn raadsman verzoekt om getuigen ter zitting te horen, terwijl er evenmin een verweer wordt gevoerd dat in redelijkheid had moeten worden opgevat als een verzoek daartoe, het achterwege blijven van een ambtshalve beslissing van de rechter om ter zitting de getuigen te horen, waarvan de gereproduceerde verklaringen voor het bewijs worden gebruikt, geen strijd oplevert

67 Cardot zaak, EHRM 3 april 1990, Series A, vol. 200. 
met het recht van de verdachte op een fair trial ${ }^{\text {se }}$. Het is echter maar de vraag of deze conclusie gerechtvaardigd is. Strikt genomen heeft het Hof zich in de Cardot zaak niet uitgelaten over eventuele schending van het recht op een 'fair trial'. De klager in deze zaak werd niet-ontvankelijk verklaard, omdat hij op nationaal niveau had nagelaten ten overstaan van de rechter zich voldoende duidelijk te beroepen op de hem volgens het verdrag toekomende rechten. Het Hof kwam aan een inhoudelijke beoordeling van de klacht niet toe.

Mag uit deze uitspraak worden afgeleid dat de verantwoordelijkheid voor de 'fairness' van de procedure, zoals Meijers van mening lijkt te zijn, primair ligt bij de verdachte en zijn raadsman? Deze interpretatie zou betekenen dat het EHRM de opvatting huldigt dat aan de verdachte geen 'fair trial' hoeft te worden geboden wanneer hij daar via zijn raadsman of zelf niet voldoende duidelijk om vraagt. Zou het Hof dat hebben bedoeld? Erg waarschijnlijk is dat niet ${ }^{\oplus}$. Waarom zou een verdachte die zich nadrukkelijk beroept op wat hem toekomt méér recht hebben op een 'fair trial' dan een verdachte die ervan uit gaat dat hij krijgt wat hem toekomt? Veel aannemelijker is, dat het Hof met zijn uitspraak in de Cardot zaak heeft willen aangeven dat de toepassing van het verdrag primair een nationale aangelegenheid $\mathrm{is}^{x}$. Van de verdachte mag worden geeist dat ook hij stappen onderneemt om te krijgen waar hij recht op heeft. Is hij daarin nalatig dan kan hij over schending van zijn recht op 'fair trial' niet meer klagen in Straatsburg. Die klager wordt niet-ontvankelijk verklaard. Het Hof voorkomt daarmee dat verdachten hun recht op een 'fair trial' misbruiken voor doeleinden waarvoor het niet is bedoeld. De 'fairness' van de procedure mag geen doel worden op zich zelf, maar moet in het teken blijven staan van een zo deugdelijk mogelijk rechterlijke uitspraak. Het recht op het ondervragen van belastende getuigen is bedoeld ter controle van de betrouwbaarheid en kwaliteit van het bewijs en niet als een ontsnappingsmogelijkheid voor een gerechtvaardigde veroordeling.

Deze eigen verantwoordelijkheid van de verdachte voor de 'fairness' van de procedure betekent echter niet dat niet ook aan de nationale rechterlijke autoriteiten

Zo G.P.M.F. Mols (1991), a.w., p. 172 en 173. Zie ook L.C.M. Meijers, Verdrag en strafproces; gedachten over een methode van werken, Zwolle 1993, p. 12.

69 Zie in dit verband ook: J. de Hullu, De afstand tot de gemiddelde verdachte; Over het recht ter zitting afstand te doen van rechtsmiddelen en de moderne benadering van 'de verdachte', In: Een rariteitenkabinet; Opvallende bepalingen in de strafwetgeving, o.r.v. A.A. Franken en A.M. van Woensel, Nijmegen 1993, p. 47: "Uiteindelijk worden uit het EVRM (dat van karakter eenzijdig is omdat het strekt ter bevordering van de rechtspositie van onder meer de verdachte burger) plichten afgeleid voor de verdachte. Niet-naleving van deze plichten leidt tot voor hem nadelige consequenties. Per saldo betekent dit dat het verdrag soms in een verslechtering van de rechtspositie van de verdachte lijkt te resulteren. Is dat de bedoeling van het verdrag. past zoiets wel bij de strekking van het verdrag, zo vraag ik me af."

70 Zie ook L.C.M. Meijers (1993), a.w., p. 11: "Het hof legt in Cardot vast dat de toepassing van het verdrag primair de taak van de nationale rechter is en dat, als het over een strafzaak gaat, verdragsaanspraken dáár eersı aan de orde moeten zijn gesteld." 
eisen mogen worden gesteld aangaande de zorg voor een eerlijke behandeling. Het kan nooit de bedoeling van het Hof zijn geweest om de nationale rechter te ontslaan van zijn plicht te waken voor een 'fair trial"? . Dit betekent dat ook de rechter er voor dient zorg te dragen dat met het oog op een contradictoire procesvoering in beginsel alle bewijs in aanwezigheid van de verdachte ter terechtzitting wordt geproduceerd.

Ik ben het dan ook maar ten dele eens met Meijers, die mijns inziens te ver gaat in zijn opvatting betreffende de uit het verdrag voortvloeiende verantwoordelijkheid van de verdediging voor de 'faimess' van de procedure. Hij schrijft: "Het EVRM neemt de verdachte serieus; het haalt hem in zijn kwaliteit van procespartij uit de kring van de personae miserabiles. Anders gezegd: het EVRM rekent, als het op de verwezenlijking van verdragsgarantie aankomt, op een alerte proceshouding. ${ }^{172} \mathrm{Ja}$, maar niet alleen op een alerte proceshouding van de verdachte en zijn raadsman. Het verdrag ontslaat de nationale rechter niet van zijn eigen verantwoordelijkheid. Men neemt de verdachte immers niet serieus, wanneer men de gebrekkige kwaliteit van het rechterlijk oordeel tracht toe te schrijven aan de laksheid van de verdediging ${ }^{73}$.

\subsubsection{Conclusie}

De uitspraak van het EHRM in de Cardot zaak kan gezien worden als een uitspraak over de verdeling van de verantwoordelijkheden betreffende de 'fairness' van de procedure. De naleving van de minimumeisen die het EVRM aan een 'fair trial' stelt, is primair een nationale aangelegenheid. De verdachte die voor de nationale rechter niet - via zijn raadsman of zelf - verzoekt om getuigen op zitting te horen, noch een verweer voert dat in redelijkheid had moeten worden opgevat als een

71 Zo ook: J. de Hullu (1993), a.w., p. 48: "Dat de verdachte burger in het EVRM als volwaardige procespartij centraal staat, impliceert geenszins dat hij aan keuzen moet worden gehouden of dat de Nederlandse strafrechter zich minder ambtshalve aan een materieel correcte afdoening gelegen most laten liggen."

72 L.C.M. Meijers (1993), a.w., p. 2.

73 Zie hierover ook A.C. 't Hart, Inquisitoir of accusatoir; Een maatstaf voor de positie van de bekennende verdachte, In: Een afzonderlijke procedure voor de bekennende verdachte?, Arnhem 1993, p. 43: "(..) Dit inzicht brengt mee dat, bij een ontwikkeling naar een meer accusatoire strafproces waarbij cen deel van de rechterlijke verantwoordelijkheid voor de bepaling van de waarheid wordt verschoven naar $O M$ en verdachte als gelijke procespartijen, niet mag worden volstaan met te poneren dat een verdachte voortaan maar in staat moct worden geacht zijn eigen boontjes te doppen'. Dan zou het mondig burgersehap beschouwd worden als een feitelijkheid, een natuurlijke eigenschap van icder mens, en zou het constructieve, normatieve en reproduktieve karakter daarvan worden vergeten. Accusatoire vormen dienen dan ook om in het strafproces de processuele voorwaarden te scheppen om de verdachte burger zo veel mogelijk in de positie van een mondige en gelijke procespartij te brengen." 
verzoek daartoe ${ }^{74}$, kan er in Straatsburg niet meer over klagen dat hem geen 'fair trial' ten deel is gevallen. Het EVRM vraagt met het oog op de toegang tot de Strautshurgse organen van de verdachte en zijn raadsman een zekere alertheid ten aanzien van de naleving van de verdedigingsgaranties die het verdrag de verdachte biedt. Dit doet er echter niet aan af, dat de rechter een eigen verantwoordelijkheid behoudt waar het gaat om de naleving van de minimumeisen die het verdag aan een 'fair trial' stelt. Dit betekent dat de rechter met het oog op een zo betrouwbaar mogelijk oordeel gehouden is ambtshalve tot het horen van getuigen over te gaan, wanneer er geen rechtvaardigende omstandigheden aanwezig zijn om daarvan af te zien ${ }^{\text {s. }}$.

\section{Onmiddellijkheidsbeginsel en een 'fair trial'}

In dit hoofdstuk werd een antwoord gezocht op de vraag in hoeverre het onmiddellijkheidsbeginsel ten grondslag ligt aan een 'fair trial'. Die vraag werd onderzocht aan de hand van de Europese jurisprudentie over het recht van de verdachte op het (doen) ondervragen van getuigen à charge. De reikwijdte van de Europese jurisprudentie is niet altijd even duidelijk doordat de uitspraken van de ECRM en het EHRM steeds zijn toegesneden op het individuele geval. Toch kan, zoals de weergegeven analyse heeft aangetoond, een duidelijke lijn worden ondekt wanneer de vele uitspraken in hun onderlinge verband worden bekeken.

Met Mols ben ik van mening dat het Hof met de formulering van de hoofdregel onomwonden heeft gekozen voor de realisering van het onmiddellijkheidsbeginsel

74 Zie hierover de Săidi zaak, EHRM 20 september 1993, Series A, vol. 261-C, §39, waaruit blijkt hoezeer de vraag of de verdachte voldoende duidelijk is geweest, afhangt van de omstandigheden van het concrete geval.

75 Zie in dit verband ook de concurring opinion van rechter Pettiti in de Saidi zaak, EHRM 20 september 1993, Series A, vol. 261-C: "Even though some of the depositions of the witnesses did not have a decisive influence on the Court of Appcal's assessment of the applicant's guilt, it would have been prudent in proceedings involving serious offences and heavy sentences to organise a confrontation with the prosecution witnesses, even if this was not expressly requested by the defence in that it did not call witnesses in the Criminal Court or seek to invoke Article 513 of the Code of Criminal Procedure in the Court of Appeal." Zie ook de annotatie van E.A. Alkema onder de Lüdi zaak in de NJ 1993, 711, p. $2944 \mathrm{t} / \mathrm{m} 2947 \mathrm{en} \mathrm{C.J.C.F.} \mathrm{Fijnaut} \mathrm{(1993),} \mathrm{a.w.,} \mathrm{p.} \mathrm{69:} \mathrm{"Als} \mathrm{tweede} \mathrm{conclusie}$ kan worden gesteld dat de effectuering van het onderhavige recht niet enkel een punt van zorg voor de justitiële autoriteiten is. Op hen rust beslist een zekere plicht om de aanwezigheid van belastende getuigen op de terechtzitting te bewerkstelligen, maar zij zijn niet gehouden tot het onmogelijkc. (..) Omgekeerd mag ook van de verdachte resp. de verdediging worden verlangd dat $x$ in in de opeenwolgende fasen van de procedure actief waken over de uitoefening van het omstreden recht en hun andere rechten. Volstrekte passiviteit hunnerzijds op dit punt kan later nog moeilijk worden gehonoreerd met het discrediteren van de eventueel voor hen ongunstige uitkomst van de gehele procedure. De rechten van de beschuldigde verdachte dienen met het oog op een eerlijk proces dus door alle partijen in het oog te worden gehouden." 
ten behoeve van een zo betrouwbaar mogelijk rechterlijk oordeel. Een 'fair trial' eist in beginsel dat alle bewijs in aanwezigheid van de verdachte en ten overstaan van de rechter wordt geproduceerd. Het Hof hecht kennelijk aan de eigen waarneming van de rechter; dit is de reden waarom de contradictoire procesvoering niet zonder meer naar het vooronderzoek kan worden verschoven. Daarvoor moeten gerechtvaardigde redenen zijn. De te rechtvaardigen uitzondering op de regel geeft tegelijkertijd aan dat het Hof het onmiddellijkheidsbeginsel niet zo absoluut heeft geformuleerd dat elke schending daarvan strijd oplevert met een 'fair trial" ${ }^{376}$. Slechts wanneer het onmiddellijkheidsbeginsel niet kan worden nageleefd, zoekt het Hof de waarborgen voor deugdelijke controle van het bewijs in de verschuiving van het contradictoire element van het onderzoek ter terechtzitting naar het vooronderzoek. De zittingsrechter mag er dan op vertrouwen dat de bespreking van het gereproduceerde getuigenbewijs, dat werd verzameld in aanwezigheid van de verdachte en/of zijn raadsman, voldoende garanties biedt voor een deugdelijk oordeel. Ter terechtzitting kan de verdediging immers nog alles aanvoeren wat zij van belang acht.

Heeft de confrontatie van de verdachte en/of zijn raadsman met de belastende getuige(n) op de een of andere manier niet kunnen plaatsvinden, dan is de controle van het bewijs noodzakelijkerwijs beperkt tot de bespreking van de gereproduceerde getuigenverklaring(en) ter zitting in aanwezigheid van de verdediging. In dergelijke situaties mag de rechter het ongecontroleerde bewijs alleen aan zijn oordeel ten grondslag leggen indien dit bewijs bevestigd wordt door voldoende ander bewijs, ten aanzien waarvan de verdachte zijn rechten wel in voldoende mate heeft kunnen uitoefenen.

\section{De invloed van de Europese jurisprudentie op het onderzoek ter terechtzitting}

De invloed van de Europese jurisprudentie over het recht op het horen van getuigen à charge op het in verre mate schriftelijke en soms geheime karakter van het strafrechtelijke onderzoek ter terechtzitting in Nederland is tot nog toe beperkt gebleven. De medeverantwoordelijkheid van de verdediging voor de 'fairness' van de procedure en het gebrek aan duidelijkheid over de eisen die het EHRM stelt aan een gerechtvaardigde uitzondering op de hoofdregel dat alle bewijs ter zitting dient te worden geproduceerd, worden door de Hoge Raad aangegrepen om de gevolgen van de gebondenheid aan het EVRM voor de inrichting van ons strafproces te beperken. Bovendien wordt door de Hoge Raad uit de Europese jurisprudentie afgeleid dat wanneer het gebruikte bewijs ten aanzien waarvan de verdedigingsrechten van de verdachte ex art. 6 EVRM onvoldoende in acht zijn genomen, voldoende steun vindt in ander bewijs, aan het gebruik daarvan voor de bewezenverklaring niets in de weg staat. 
Overigens dient bij het lezen van de relevante jurisprudentie van de Hoge Raad bedacht te worden dat op nationaal niveau de vraag of de rechter op verzoek van de verdediging dient over te gaan tot het dagvaarden of oproepen en horen van voor de verdachte belastende getuigen, wordt beantwoord aan de hand van een tweetal criteria ${ }^{\pi}$.

Ex art. 280 lid 4 Sv en lid 6 luidt dat criterium: of de verdediging door het achterwege blijven van de dagvaarding of de oproeping (lid 4) dan wel het horen (lid 6) van de gewenste getuige redelijkerwijs niet in zijn verdediging kan worden geschaad. Aan dit criterium is voldaan indien het dagvaarden of oproepen als nutteloos dan wel het horen van die getuige als overbodig kan worden aangemerkt ${ }^{78}$. Het dagvaarden of ofroepen van een getuige is nutteloos wanneer met grote waarschijnlijkheid te voorspellen valt dat een dergelijk bevel geen effect zal sorteren omdat de betrokkene niet binnen een redelijke termijn op de terechtzitting zal verschijnen ${ }^{x}$. Overbodig is een verhoor wanneer de rechter ervan overtuigd is dat een verhoor van de getuige niet meer kan bijdragen tot opheldering van de $\mathrm{zaak}^{\mathrm{k}}$. Ook in art. $282 \mathrm{~Sv}$ lid $2 \mathrm{~Sv}$ is bepaald dat de rechter van het hernieuwd oproepen dan wel dagvaarden van nietverschenen maar wel op de lijst geplaatste getuigen om dezelfde redenen kan afzien. Ex art. 328 jo. $315 \mathrm{~Sv}$ wordt de vraag of de rechter op verzoek van de verdachte dient over te gaan tot het dagvaarden of oproepen en horen van bepaalde getuigen beantwoord aan de hand van het criterium: of aan de rechter de noodzakelijkheid van een dergelijk verhoor is gebleken ${ }^{\mathrm{si}}$. Dit criterium biedt de rechter meer beoordelingsvrijheid dan het criterium ex. art. 280 lid 4 en lid $6 \mathrm{~Sv}^{28}$.

Los echter van de vraag of de rechter bij zijn beslissing op het verzoek van de verdediging om een belastende getuige ter zitting te dagvaarden of op te roepen en te horen, de juiste maatstaf heeft aangelegd, staat de vraag of de gereproduceerde verklaring van de getuige uit het vooronderzoek voor het bewijs mag worden gebruikt als die getuige door welke oorzaak ook niet ter zitting is verschenen om daar door de verdediging ondervraagd te kunnen worden. Het door toepassing van het nationale recht verkregen resultaat moet namelijk ook nog de toets aan art. 6 EVRM kunnen

77 Zie over het onderscheid van deze criteria en cen beknopte historische uilleg daarvan, de annotatic van Knigge onder HR 13 oktober 1992, NJ 1993, 143.

78 Zic over de ontwikkeling van dit in de wet neergelegde systeem onder andere: C.F. Rüter, Ongehoord - Over getuigen en deskundigen ter terechtzitting, In: Ad Personam Ch.J. Enschedé, Zwolle 1981, p. $237 \mathrm{t} / \mathrm{m}$ 263; Th.W. van Veen, Het nieuwe art. 280 Sv: doen alsof onze neus bloedt?, NJB 1984, p. 1420 1/m 1422; G.P.M.F. Mols, De niet verschenen getuige: enkele gedachten n.a.v. recente jurisprudentie, Advocatenblad 1987, p. 237 t/m 241 en G.J.M. Corstens, Getuigen op de zitting, D\&D 1992, p. $205 \mathrm{t} / \mathrm{m} 211$.

79 HR 13 maart 1979, NJ 1979, 268; HR 18 november 1980, NJ 1981, 135.

80 HR 10 januari 1978, NJ 1978, 595.

81 HR 19 maart 1985, NJ 1985, 702; HR 3 juni 1986, NJ 1987214.

82 Zie ook G.J.M. Corstens (1992), a.w., p. 528 t/m 543, m.n. p. 533. 
doorstaan ${ }^{8}$. De volgende bespreking van een selectie uit de meest recente jurisprudentie van de Hoge Raad spitst zich toe op die toets.

\subsection{Medeverantwoordelijkheid van de verdachte}

De uitspraak van het EHRM in de Cardot zaak wordt door de Hoge Raad zo geïnterpreteerd dat wanneer de verdediging daarom niet verzoekt, de rechter niet ambtshalve behoeft over te gaan tot het horen van getuigen waarvan de gereproduceerde verklaringen voor het bewijs worden gebruikt.

In een arrest van 1 oktober 1992 overwoog de Hoge Raad:

"Zowel de politierechter als het hof hebben het bewijs van het ten laste gelegde doen steunen op o.m. een proces-verbaal behelzende een door $\mathrm{H}$. jegens de politie afgelegde verklaring, (..). Voor zover het middel erover beoogt te klagen dat de verdachte niet in de gelegenheid is gesteld vragen te (doen) stellen aan meergenoemde $\mathrm{H}$. stuit het af om de omstandigheid dat uit geen der stukken blijkt dat de verdachte of zijn raadsman daartoe de wens te kennen heeft gegeven, terwijl de voorts in het middel verdedigde stelling dat het hof ambtshalve $\mathrm{H}$. als getuige had moeten dagvaarden geen steun vindt in het recht."."4

In HR 21 januari 1992, NJ 1992, 263 werd uitgemaakt dat het hof zonder schending van art. 6 lid 3 onder d EVRM de door de 4 medeverdachten tegenover de politie afgelegde, en door de verdachte betwiste, verklaringen tot het bewijs kon bezigen, omdat door of namens de verdachte niet was verzocht deze personen ter zitting te (doen) horen, bij welke gelegenheid een rechtstreekse confrontatie met de verdachte had kunnen plaatsvinden.

Ook uit HR 17 november 1992, NJ 1993, 617 blijkt dat wanneer de verdachte niet uitdrukkelijk de gelegenheid is gegeven om vragen te (doen) stellen aan de getuigen, dit volgens de Hoge Raad niet in strijd is met art. 6 lid 3 onder d EVRM, wanneer niet blijkt dat door of namens de verdachte de wens kenbaar is gemaakt tot het (doen) stellen van vragen aan de getuigen.

Tenslotte kan hier nog gewezen worden op een uitspraak van de Hoge Raad van 25 mei 1993. Daarin overwoog de cassatierechter:

"Blijkens de processen-verbaal van de terechtzittingen in eerste aanleg en in hoger beroep heeft de raadsman aldaar onder meer aangevoerd dat de verdediging, in strijd met het bepaalde in art. 6 eerste lid onder d EVRM niet in de gelegenheid is geweest het verhoor van de getuige Rodriguez in de VS bij te wonen en de getuige te (doen) ondervragen. (..) In het midden kan blijven of het hof heeft kunnen oordelen dat de rechter-commissaris het verzoek van de raadsman de getuige Rodriguez te (doen) horen terecht heeft afgewezen. 's Hofs in cassatie niet bestreden vaststelling dat de verdachte geen gebruik heeft gemaakt

83 Zic Knigge in zijn annotatic bij HR 9 juni 1992, NJ 1992, 772.

84 Zie HR 1 oktober 1991, NJ 1922, 198, rechtsoverwegingen 5.1 en 5.2. 
van de in art. 263 tweede lid in verbinding met art. 414 tweede lid Sv gegeven mogelijkheid om de getuige Rodriguez aan het Openbaar Ministerie op te geven als te dagvaarden of op te roepen getuige draagt zijn verwerping van het verweer zelfstandig."

Ook de eisen die de Hoge Raad in navolging van de Kostovski uitspraak stelde aan een anonieme getuigenverklaring wil deze voor het bewijs kunnen worden gebruikt, leidden uitzondering wanneer door of namens de verdachte niet de wens kenbaar wordt gemaakt de anoniem gebleven persoon te kunnen ondervragen of te doen ondervragen ${ }^{*}$.

In het 'Vrouwenhandelarrest' overwoog de Hoge Raad':

"Het bij pleidooi voorgedragen middel gaat er terecht van uit dat in het licht van de uitspraak van het EHRM van 20 november 1989 (serie A vol. 166; NJ 1990, 245) moet worden aangenomen dat aan het gebruik van anonieme verklaringen voor de bewijslevering meer eisen moeten worden gesteld dan tot nu toe in de rechtspraak van de Hoge Raad tot uiting zijn gekomen. Daarbij kan als uitgangspunt gelden dat in een proces-verbaal neergelegde verklaringen van anoniem gebleven personen in beginsel slechts bruikbaar zijn voor het bewijs indien is voldaan aan bepaalde voorwaarden, waarvan de belangrijkste zijn dat de verklaring is afgenomen door een rechter die zelf de identiteit van de getuige kent, die in het van het verhoor opgemaakte proces-verbaal, gemotiveerd heeft doen blijken van zijn oordeel omtrent de betrouwbaarheid van de getuige en omtrent de door deze opgegeven redenen voor zijn wens anoniem te blijven, en die de verdediging in de gelegenheid heeft gesteld op enigerlei wijze aan de getuige vragen te stellen of te doen stellen. Deze regel lijdt echter uitzondering in een geval als het onderhavige, dat hierdoor wordt gekenmerkt dat:

- uit de stukken van het geding niet blijkt dat door of namens de verdachte - die in beide instanties door een raadsman werd bijgestaan - op enig moment in het geding de wens te kennen is gegeven in de gelegenheid te worden gesteld de anoniem gebleven persoon wiens verklaring voor het bewijs is gebezigd, te ondervagens.;

- de bewezenverklaring in belangrijke mate steunt op bewijs uit andere, niet-anonieme, bron;

- de rechter heeft doen blijken dat hij de betrokken verklaring behoedzaam en terughoudend heeft gebezigd".

In latere arresten heeft de Hoge Raad de omstandigheden die een uitzondering op de in het Vrouwenhandel-arrest geformuleerde uitgangspunt rechtvaardigen, verruimd in zoverre dat verdachte niet enkel dient kenbaar te maken dat hij de anoniem

85 Zie HR 25 mei 1993, NJ 1993, 784.

86 Bij deze jurisprudentie over het gebruik van anoniem getuigenbewijs moet worden bedacht dat sinds 1 februari 1994 de Wet Getuigenbescherming in werking is getreden, zodat deze 'oude' jurisprudentie aan waarde zal inboeten. Zie over de Wet Getuigenbescherming hoofdstuk 5 \$ 3 e.v.

87 Zie HR 2 juli 1990, NJ 1990, 692, rechtsoverwegingen 5.2 en 5.3.

88 Cursivering door de auteur. 
gebleven persoon wenst de (doen) ondervragen, maar ook dat hij de betrouwbaarheid van de verklaring van de desbetreffende anoniem gebleven persoon dient te betwisten".

\subsection{Onduidelijkheid over de hardheid van de hoofdregel}

In een arrest van 1 oktober 1991 oordeelde de Hoge Raad:

"De afwijzing van het verzoek met betrekking tot B., T. en H. (dit waren voor de verdachte belastende getuigen, DG), die zoals het hof heeft vastgesteld door de rechter-commissaris zijn gehoord in tegenwoordigheid van de raadsman die in de gelegenheid is gesteld vragen te stellen ${ }^{\circ}$, berust op het oordeel van het hof dat de verdachte door het achterwege blijven van het verhoor ter terechtzitting redelijkerwijs niet in zijn verdediging kan worden geschaad. Deze overweging moet - (..) - aldus worden verstaan dat het hof daarin tevens tot uitdrukking heeft gebracht dat het horen van die personen niet noodzakelijk of wenselijk was te achten. Dit oordeel van het hof is niet onbegrijpelijk, (..), in aanmerking genomen dat het aangevoerde slechts inhoudt de op geen enkele wijze nader gespecificeerde stelling dat aangeefsters geconfronteerd zouden moeten worden met de verklaringen van "een groot aantal andere getuigen" die zijn afgelegd nadat zij bij de rechter-commissaris gehoord waren." ${ }^{\text {PI }}$

In een uitspraak van 22 september 1992 komt de Hoge Raad tot een soortgelijk oordeel. Hoewel in feitelijke aanleg bij het hof door de verdediging met een beroep op art. 6 lid 3(d) EVRM was verzocht om een voor de verdachte belastende getuige op zitting te horen, weigert het hof dit verzoek te honoreren. In cassatie overweegt de Hoge Raad:

89 Zie HR 2 oktober 1990, NJ 1991, 130, HR 16 oktober 1990, NJ 1991, 203 en HR 26 maart 1991, NJ 1991, 614. Zie hierover ook A-G Leijten in zij conclusie bij HR 11 februari 1992, NJ 1992, 516 en J.L.M. Boek en J.F. Nijboer, Ongehoorde getuigen, D\&D 1992, p. 1006 t/m 1014. Zie in dit verband ook nog: HR 1 oktober 1991, NJ 1992, 139.

90 Cursivering door de auteur.

91 HR 1 oktober 1991, NJ 1992, 197, onder 6.3. Zie ook Schalken in zijn annotatie onder dit arrest: "Het verzoek van de raadsman om alle getuigen die aangifte hadden gedaan ter terechtzitting op te roepen, is door het hof tot tweemaal toe afgewezen. Niettemin zijn de verklaringen van alle vier getuigen tot het bewijs gebezigd. In hoeverre is deze gang van zaken, vooral tegen de achtergrond van recente Straatsburgse jurisprudentie, toelaatbaar? Het verzock de getuigen (slachtoffers/aangeefsters) ter zitting op te roepen die tevens door de rechter-commissaris waren gehoord, werd door het hof afgewezen met als reden dat de verdachte door het achterwege laten van hun verhoor redelijkerwijze niet in zijn verdediging kan worden geschaad. Zij waren immers, aldus het hof, door de rechter-commissaris gehoord in tegenwoordigheid van de raadsman die in de gelegenheid is geweest de vragen te stellen die hij in het belang van de verdediging achtte. Derhalve, concludeert de Hoge Raad, heeft het hof tot uitdrukking gebracht dat het horen van die getuigen niet noodzakelijk of wenselijk werd geacht. Het hof had tot dit oordecl kunnen komen, omdat hetgeen de raadsman ter ondersteuning van zijn verzock had aangevoerd, als vaag wordt aangemerkt (r.o. 6.3.). 
"Bij de afwijzing van een verzoek tot het ter zitting horen van een getuige, heeft het hof een juiste maatstaf gehanteerd. 's Hofs oordeel dat van de noodzaak tot het ter terechtzitting horen van getuige P. niet is gebleken, is niet onbegrijpelijk nu het hof kennelijk heeft geoordeeld, zoals het heeft kunnen doen, dat de door deze getuige (..) aan de rechter-commissaris afgelegde verklaring niet wezenlijk verschilt van diens reeds eerder aan de rechter-commissaris afgelegde verklaring - welke door het hof als bewijsmiddel onder 3 is gebruikt - en de verdachte en diens raadsvrouwe bij het afleggen van de tweede verklaring aanwezig zijn geweest en de getuige vragen hebben kunnen stellen. ${ }^{\text {992 }}$

Uit deze en andere ${ }^{03}$ jurisprudentie kan worden afgeleid dat de HR van mening is dat wanneer de verdachte gedurende het vooronderzoek reeds in de gelegenheid is geweest om de hem belastende getuige te (doen) ondervragen, de wens om deze getuige nogmaals ter zitting ten overstaan van de rechter te (doen) ondervragen, kan worden afgewezen zonder in strijd te komen met art. 6 EVRM. De rechter mag de in het bijzijn van de verdachte en/of zijn raadsman bij de rechter-commissaris afgelegde verklaring van de desbetreffende getuige zonder meer aan zijn oordeel ten grondslag leggen. De Hoge Raad interpreteert de Straatsburgse jurisprudentie betreffende het recht op het horen van getuigen zo dat van de door het EHRM geformuleerde hoofdregel mag worden afgeweken, mits maar de rechten van de verdediging in acht zijn genomen. In de ogen van de Hoge Raad stelt het EHRM geen zelfstandige eisen aan de noodzakelijkheid om van de hoofdregel af te wijken.

92 HR 22 september 1992, NJ 1993, 85, onder 5.2.

93 Zie ook HR 12 januari 1993, NJ 1993, 511 waarin de Hoge Raad zich aansluit bij de conclusie van de A-G Meijers: "Badia Lofti was in deze zaak een belangrijke, zells de belangrijkste, getuige, zodat ook een beslissing haar voor de vierde kecr, maar voor het eérst in appel, te horen niet onbegrijpelijk was geweest. Ik meen evenwel dat het hof in de omstandigheden van dit geval waaronder ik ook betrek de omstandigheid dat de getuige het slachtoffer was dat al drie keer een in de kern van de zaak gelijkluidende verklaring heeft afgelegd, waarbij de laatste keer voor de rechtbank in aanwezigheid van verzoeker en zijn raadsman, én de omstandigheid dat haar verklaringen door die van andere getuigen worden bevestigd -, zonder met enige rechtsregel in strijd tc komen, van oordeel mocht zijn dat door het achterwege blijven van een vierde verhoor van Lofti verzoeker redelijkerwijze niet in zijn verdediging kon worden geschaad." Zie verder HR 29 juni 1993, NJ 1993, 717; HR 30 november 1993, NJ 1994, 247.

Zie ook HR 1 februari 1994, NJB-katern 1994, p. 158, nr. 67: "(i) In het licht van het EVRM is het gebruik voor het bewijs van een ambtsedig proces-verbaal voor zover inhoudende een niet ter terechtzitting afgelegde de verdachte belastende verklaring niet zonder meer ongeoorloofd en in het bijzonder niet onverenigbaar met art. 6 lid 1, en lid 3, aanhef en onder d, EVRM; (ii) Van onverenigbaarheid als onder (i) bedoeld is in icder geval geen sprake indien de verdediging in enig stadium van het geding, hetzij op de terechtzitting hetzij daarvoor, de gelegenheid heeft gehad om een dergelijke verklaring op haar betrouwbaarheid te toetsen en aan te vechten door de persoon die de verklaring heeft afgelegd als getuige te (doen) ondervragen." 
In een arrest van 2 maart 1993 oordeelt de Hoge Raad: "In het middel wordt voorts de vraag aan de orde gesteld of de processen-verbaal van de politie, voor zover verklaringen van de getuige Van Lent bevattende, als bewijsmiddel konden worden gebruikt, nu de verdachte geen gelegenheid heeft gehad deze getuige te ondervragen. Deze vraag dient bevestigend te worden beantwoord, daar de bewezenverklaring niet in overwegende mate berust op voormelde verklaring", zoals kan blijken uit de hiervoor onder 4.2. weergegeven bewijsmiddelen. ${ }^{\text {nos }}$ In een uitspraak van 12 mei 1992, acht de Hoge Raad een verweer omtrent schending van art. 6 lid 3 onder d EVRM door het hof toereikend weerlegt, mede in aanmerking genomen dat de voor het bewijs gebruikte getuigenverklaringen voldoende steun vinden in het de andere gebezigde bewijsmiddelen ${ }^{*}$. Bij de omstandigheden die een uitzondering rechtvaardigden die normaliter door de Hoge Raad werden gesteld aan het gebruik van anonieme getuigenverklaringen voor het bewijs, hoort ook de omstandigheid dat de bewezenverklaring in belangrijke mate steunt op bewijs uit andere, niet anonieme bron ${ }^{97}$.

De Hoge Raad leidt uit de Straatsburgse jurisprudentie af dat het gebruik van getuigenbewijs ten aanzien waarvan de verdediging niet in de gelegenheid is geweest zijn recht op ondervraging uit te oefenen, zonder schending van art. 6 EVRM voor het bewijs mag worden gebruikt, mits dit bewijs maar voldoende steun vindt in ander bewijs ${ }^{\text {s. }}$.

\subsection{Conclusie}

Uit het oogpunt van het onmiddellijkheidsbeginsel heeft ons strafproces onder invloed van de Europese jurisprudentie weinig verandering ondergaan. Het onderzoek ter

94 Cursivering door de auteur.

95 Zic HR 2 maart 1993, NJ 1993, 672, r.o. 5.2.

96 Zic HR 12 mei 1992, NJ 1992, 660. Zie ook HR 29 maart 1994, NJB-katern 1994, p. 232, nr. 92.

97 Zie HR 2 oktober 1990, NJ 1991, 130; HR 26 maart 1991, NJ 1991, 614; HR 11 februari 1992, NJ 1992 516; HR 9 juni 1992, NJ 1992, 772; HR 9 juni 1992, NJ 1992, 773.

98 Zie ook HR 1 februari 1994, NJB-katern 1994, p. 158, nr. 67:

"(i) In het licht van het EVRM is het gebruik voor het bewijs van een ambtsedig proces-verbaal voor zover inhoudende cen nict ter terchtzitting afgelegde de verdachte belastende verklaring niet zonder meer ongeoorloofd en in het bijzonder niet onverenigbaar met art. 6, lid 1, en lid 3, aanhef en onder d, EVRM;

(ii) Van onverenigbaarheid als onder (i) bedoeld is in ieder geval geen sprake indien de verdediging in enig stadium van het geding, hetzij op de terechtzitting hetzij daarvoor, de gelegenheid heeft gehad om een dergelijke verklaring op haar betrouwbaarheid te toetsen en aan te vechten door de persoon die de verklaring heeft afgelegd als getuige te (doen) ondervragen. (..) Voorts is van ongeoorloofdheid als onder (i) bedoeld geen sprake indien genoemde gelegenheid heeft ontbroken, doch die verklaring in belangrijke mate steun vindt in andere bewijsmiddelen." 
terechtzitting wordt in het algemeen nog steeds gekenmerkt door zijn schriftelijke karakter. De Hoge Raad is van mening dat wanneer de verdachte niet uitdrukkelijk verzoekt om getuigen ter zitting te horen, de rechter daartoe in beginsel ${ }^{\infty}$ niet ambtshalve behoeft over te gaan. De gereproduceerde getuigenverklaringen uit het vooronderzoek kunnen voor het bewijs worden gebruikt. Daarnaast meent de Hoge Raad dat wanneer de verdachte gedurende het vooronderzoek de gelegenheid heeft gehad de hem belastende getuige te (doen) ondervragen, er geen noodzaak meer bestaat deze getuige nogmaals ter zitting te horen, wil zijn gereproduceerde verklaring voor het bewijs kunnen worden gebruikt. Dit heeft tot gevolg dat wanneer de zittingsrechter het wel nodig acht dat een getuige op verzoek van de verdediging wordt gehoord, de zaak meestal wordt terugverwezen naar de rechter-commissaris, met de opdracht de betreffende getuige te horen in het bijzijn van de verdachte en/of zijn raadsman. Tenslotte behoeft, volgens onze cassatierechter, de verdachte niet het recht te worden geboden de hem belastende getuige te ondervragen, indien de bewezenverklaring voldoende steun vindt in ander bewijs.

Deze praktijken worden door de Hoge Raad in overeenstemming geacht met de jurisprudentie van het EHRM inzake het horen van getuigen à charge.

Aan het schriftelijke karakter van het onderzoek ter terechtzitting (zie hoofdstuk drie) is dientengevolge weinig afbreuk gedaan. Wat betreft de geheime aspecten van ons onderzoek ter terechtzitting, kan worden vastgesteld dat de Europese jurisprudentie evenmin een einde heeft gemaakt aan het gebruik van anonieme getuigenverklaringen voor het bewijs.

In de visie van de Hoge Raad dwingt de rechtspraak van de ECRM en het EHRM de nationale zittingsrechter in zijn algemeenheid niet om over te gaan tot een zelfstandige toetsing van het door de officier van justitie aangedragen bewijs, zelfs niet wanneer de verdediging nadrukkelijk een beroep doet om het hem toekomende recht om de hem belastende getuige ter terechtzitting te (doen) ondervragen.

\section{Samenvatting}

Iedere verdachte heeft recht op een 'fair trial'. Dit betekent dat iedere verdachte het recht heeft om de hem belastende getuigen te (doen) ondervragen. Omdat de verdachte in het kader van een 'fair trial' eveneens het recht toekomt op een contradictoire procesvoering en berechting door een onafhankelijk en onpartijdiggerecht, betekent dit in beginsel dat alle (getuigen)bewijs op de terechtzitting in aanwezigheid van de verdachte moet worden geproduceerd. Onder omstandigheden mag de rechter

99 Zie voor een aantal zeer specifieke - die daarom hier buiten beschouwing blijven - gevallen waarin de Hoge Raad van mening is dat rechter wél ambtshalve tot het dagvaarden of oproepen van getuigen dient over te gaan bij gebreke waarvan processen-verbaal voor zover inhoudende de door de desbetrefiende personen in het opsporingsonderzoek afgelegde verklaringen niet tot het bewijs kunnen worden gebezigd: HR 1 februari 1994, NJB-katern 1994, p. 158 en 159, nr. 67. 
zijn oordeel baseren op gereproduceerd getuigenbewijs. In dat geval moet het voor de rechter noodzakelijk zijn om gebruik te maken van dit gereproduceerde bewijs en moeten de rechten van de verdediging in acht zijn genomen.

Dat laatste betekent dat de rechter in beginsel alleen gereproduceerd getuigenbewijs aan zijn oordeel ten grondslag mag leggen als de verdachte gedurende enige fase van het vooronderzoek een adequate en gepaste gelegenheid heeft gehad de betreffende getuige te (doen) ondervragen. Daarvoor is in beginsel noodzakelijk dat de verdediging op de hoogte is van de identiteit van deze getuige. Onder omstandigheden is de bekendheid van de verdediging met een aangenomen identiteit van de getuige voldoende. Aanwezigheid van de raadsman bij de confrontatie tussen de verdachte en de getuige tijdens het vooronderzoek is daartoe niet onontbeerlijk. Soms mag de rechter ook gereproduceerd getuigenbewijs aan zijn oordeel ten grondslag leggen wanneer de verdachte gén gelegenheid heeft gehad de betreffende getuige te (doen) ondervragen, maar dan mag het gereproduceerde getuigenbewijs niet het enige bewijs vormen waarop de rechter zijn veroordeling baseert en moet dit bewijs gesteund worden door ander bewijs ten aanzien waarvan de verdedigingsrechten van de verdachte wel in acht zijn genomen.

Het voorgaande gaat niet alleen op, wanneer de verdachte of zijn raadsman voldoende duidelijk te kennen geeft de helastende getuigen ter zitting te willen horen. Het feit dat het EHRM aan de ontvankelijkheid van de klager eisen stelt, betekent immers niet dat de rechter is ontslagen van zijn zorg voor een eerlijke en openbare behandeling van een ieders strafzaak. De rechter behoudt zijn eigen verantwoordelijkheid en dat wil zeggen dat hij in beginsel ${ }^{1, i \mid}$ gehouden blijft om ambtshalve tot het ter zitting dagvaarden dan wel oproepen van getuigen over te gaan, wanneer er geen rechtvaardigende omstandigheden aanwezig zijn om van de hoofdregel af te wijken. Dit alles leidt tot de slotsom dat het onmiddellijkheidsbeginsel inderdaad aan het recht op een 'fair trial' ten grondslag ligt, maar dat niet elke schending daarvan strijd oplevert met het recht op een 'fair trial'.

Tegelijkertijd moet worden vastgesteld, dat het onderzoek ter terechtzitting in Nederland onder invloed van de Straatsburgse jurisprudentie wat beteft de erkenning

100 Dit is mogelijk anders, wanneer de verdachte afstand van recht hecft gedaan. Het EHRM hanteert ten aanzicn van art. 6 EVRM het uilgangspunt dat op busis van toestemming van de verdachte een inbreuk mag worden gemaakt op dc, door de daarin neergelegde rechten, beschermde rechtsbelangen. Aan een rechtsgcldige afstand van recht worden door het Hof echter wcl voorwaarden gesteld, waarvan wel de belangrijkste is dat deze afstand blijkt uit een duidclijke verklaring van de verdachte. Bovendien houdt het Hof een slag om de arm: er kunnen zich omstandigheden voordoen waarin de afstand van recht onvoldoende basis biedt om een inbrcuk te mogen maken op ến van de door art. 6 EVRM beschermde rechtsbelangen. Er bestaan dienaangaande nog veel onduidelijkheden. De Straatsburgse instanties hebben zich namelijk nog niet uitgesproken over alle in art. 6 EVRM genoemde rechten en bovendien niet aangegeven in welke gevallen zich een uitzondering kan voordoen op het uitgangspunt dat op basis van afstand van recht de rechtsbelangen van de verdachte kunnen worden aangetast. Zie J.D. den Hartog (1992), a.w., p. $156 \mathrm{t} / \mathrm{m}$ 178 , met name p. 160 . 
van het onmiddellijkheidsbeginsel niet veel verandering heeft ondergaan. Dat is een rechtstreeks gevolg van de uitleg die de Hoge Raad aan de Straatsburgse rechtspraak geeft. Wanneer de verdachte gedurende het vooronderzoek de gelegenheid heeft gehad de hem belastende getuige te (doen) ondervragen, of bij gebreke daarvan de bewezenverklaring steun vindt in ander bewijs, is het volgens de Hoge Raad zonder meer in overeenstemming met art. 6 EVRM om de gereproduceerde verklaring van de desbetreffende getuige uit het vooronderzoek voor het bewijs te gebruiken. Verder blijkt de Hoge Raad van mening dat de verdachte geen 'fair trial' behoeft te worden geboden, wanneer deze daar zelf niet om vraagt. Afgezien van het feit dat deze conclusie door de Europese jurisprudentie niet wordt gerechtvaardigd, getuigt deze opvatting van weinig zelfbewustzijn. Het gevolg is dat het onderzoek ter terechtzitting nog steeds wordt gekenmerkt door zijn schriftelijke en soms geheime karakter. 


\section{Enkele plannen tot partiële herziening van het Wetboek van Strafvordering getoetst aan het onmiddellijkheidsbeginsel}

\section{Inleiding}

Uit de hoofdstukken drie en vier kwam naar voren dat in het Nederlandse strafproces sinds het 'De auditu'-arrest nauwelijks wordt recht gedaan aan het onmiddellijkheidsbeginsel en dat de invloed van de Europese jurisprudentie over het recht op het horen van getuigen daaraan tot nog toe weinig heeft veranderd. Deze conclusie was mede het resultaat van een analyse van de rechtspraak van de Hoge Raad. In dit laatste hoofdstuk gaat het niet langer over uitspraken van de cassatierechter, maar staan de opvattingen van onze tegenwoordige wetgever centraal. Aan de hand van een drietal (deels verwezenlijkte) plannen om te komen tot een partiële herziening van het Wetboek van Strafvordering wordt bekeken hoe onze huidige wetgever ${ }^{i}$ denkt over het belang van het onmiddellijkheidsbeginsel voor een goed ingericht onderzoek ter terechtzitting. Die plannen betreffen allereerst de herziening van het gerechtelijk vooronderzoek, ten tweede de vergroting van de bescherming van bedreigde getuigen en ten derde de creatie van een verkorte procedure voor bekennende verdachten. Ik heb gekozen voor de bespreking van deze plannen omdat zij gevolgen hebben voor de wijze van bewijsvoering in ons strafproces.

Er wordt niet alleen ingegaan op de vraag welke consequenties de genoemde plannen hebben voor de realisering van het onmiddellijkheidsbeginsel, maar ook wordt stilgestaan bij de vraag hoe deze consequenties mijns inziens moeten worden gewaardeerd.

1 Ruim een week voordat het manuscript van dit boek naar de drukker ging. werd minister van justitie Hirsch Ballin 'gedwongen' tot aftreden naar aanleiding van de 'IRT-affaire'. Waar in dit hoofdstuk wordt gesproken van 'de minister' dan wel 'de minister van justitie' wordt daanmee bedoeld de voormalige minister van justitie van het derde kabinet Lubbers, de heer Hirsch Ballin. 


\section{Herziening van het gerechtelijk vooronderzoek}

Momenteel is er bij de Tweede Kamer een wetsvoorstel aanhangig betreffende de herziening van het gerechtelijk vooronderzoek ${ }^{2}$. Dit wetsvoorstel werd vooraf gegaan door een rapport van de Commissie Herijking Wetboek van Strafvordering, die naar haar voorzitter Ch.M.J.A. Moons beter bekend is geworden als de Commissie Moons. Deze Commissie werd ingesteld bij besluit van 13 september 1988 en kreeg als taak de minister van justitie van advies te dienen over onder meer de vraag of de regeling in het Wetboek van Strafvordering inzake het gerechtelijk vooronderzoek wijziging behoeft'. Voor zover dit uit het oogpunt van het onmiddellijkheidsbeginsel van belang is, zal eerst het Commissierapport over de herziening van het gerechtelijk vooronderzoek worden besproken. Daarna zal worden ingegaan op het wetsvoorstel inzake de herziening van het gerechtelijk vooronderzoek.

\subsection{Het rapport van de Commissie Moons}

De Commissie Moons heeft zich getuige haar rapport afgevraagd of het gerechtelijk vooronderzoek al dan niet moet worden gehandhaafd. $\mathrm{Zij}$ is van oordeel dat het gerechtelijk vooronderzoek moet worden behouden. Het zijn met name de overwegingen van de Commissie die tot dit oordeel hebben geleid, die hier bespreking behoeven. Uit een oogpunt van het onmiddellijkheidsbeginsel zijn er immers goede argumenten voorhanden die pleiten vóór de afschaffing van het gerechtelijk vooronder$z^{2} k^{5}$. Het galat hier om dezelfde argumenten als die in 1974 in Duitsland hebben geleid tot afschaffing van het gerechtelijk vooronderzoek $k^{6}$. Alvorens deze nader te

2 Wetsvoorstel Partiële wijziging van het Wetboek van Strafvordering; (herziening van het gerechtelijk vooronderzoek), (TK 23251 ).

3 Herziening van het gerechtelijk vooronderzock: een rapport van de Commissic herijking Wetbock van Strafvordering / (voorzitter Ch.M.J.A. Moons), Arnhem 1990.

4 Commissie rapport (1990), a.w., p. 3.

5 Zie in dit verband ook: T. Prakken, Naar een tweesporig strafproces?, NJB 1992, p. 1208: "Het onmiddellijkheidsbeginsel zots in ere hersteld moetern worden en dat betekent dat het GVO beter zou kunnen verdwijnen."

6 De Commissie Moons was van mening dat de regeling; van het strafproces in het Duitse recht op belangrijke punten zo zeer afwijkt van die in het Nederlandse recht, dat de argumenten voor afschaffing wan het gerechtelijk wooronderzoek niet zonder meer gelding hebben in de Nederlandse; situatie. Zie het Cornmissie rapport (1990), a.w., p. 24. Helaas heeft de Commissie zich voaral laten voorlichten over de regeling van het Duitse strafproces en niet zo zeer over de argumenten voor de afschafling van het gerechtelijk vooronderzoek in Duitsland. Dit blijkt uit het rapport dat door P.J.P. Tak en J.A.W. Lensing op verzoek van de Commissie wercl vervaardigd. Dit rapport is later uitgegeven onder de titet: Het voorbereidend onderzoek rechtsvergelijkend onderzocht, Arnhem 1990. Anders dan de Commissie meent, ben ik varı mening dat de uit de Duitse literatuur te halen argumenten vóor afschaffing van het gerechielijk vooronderzoek in hun gelding niet noxdzakelijk zijn beperkt tot het Duitse strafprocesrecht. 
bekijken, wordt eerst uit de doeken gedaan waarom de Commissie Moons van mening is dat het gerechtelijk vooronderzoek moet blijven bestaan'.

\subsubsection{Argumenten van de Commissie Moons voor het behoud van het gerechtelijk vooronderzoek}

Afschaffing van het gerechtelijk vooronderzoek kan ertoe leiden dat de officier van justitie leider wordt van het voorbereidend onderzoek en dat de rechter-commissaris een lijdelijke, controlerende en toetsende rol krijgt toebedeeld. In dat geval beschikt de rechter-commissaris niet meer over de bevoegdheid om ambtshalve dwangmiddelen toe te passen, maar kan hij slechts beslissen op vordering van de officier van justitie over de uitoefening van bepaalde onderzoekshandelingen.

De Commissie wijst een dergelijke opzet van het voorbereidend onderzoek van de hand, hoewel zij deze opzet theoretisch gezien de meest zuivere acht, in die zin dat de rechter-commissaris en de officier van justitie hun eigenlijke taken uitoefenen zonder dat er sprake is van functievermenging. De argumenten die ten tijde van de invoering van het Wetboek van Strafvordering voor dezelfde stellingname naar voren werden gebracht, acht de Commissie onverminderd van kracht: "De rechtercommissaris wordt als onderzoeksrechter nu eenmaal tegenover de verdachte en de verdediging minder dan de officier van justitie als partij evaren en wordt daarom gemakkelijker als zodanig erkend en geaccepteerd. Bovendien is de rechter-commissaris in ons rechtsstelsel ingeleefd en valt daaruit (..) moeilijk weg te denken."

Naast deze twee vooral praktische bezwaren heeft de Commissie ook een tweetal argumenten van meer principiële aard tegen de afschaffing van het gerechtelijk vooronderzoek.

Allereerst vreest de Commissie dat de exclusieve overdracht van de leiding van het voorbereidend onderzoek aan de officier van justitie ten koste zal galan van de rechtsbescherming van de verdachte. $Z i j$ acht het voor de evenwichtigheid van het voorbereidend onderzoek van groot belang dat tijdens dat onderzoek getuigen en deskundigen ook door een rechter kunnen worden gehoord. Daarnaast ziet zij in de betrokkenheid van de rechter-commissaris niet alleen bij de toepassing doch vooral bij de uitvoering van ingrijpende dwangmiddelen een belangrijke waarborg voor een rechtmatig verloop daarvan?.

Voorts is de Commissie bevreesd voor twee mogelijke gevolgen van een opzet van het voorbereidend onderzoek waarbij aan de officier van justitie de leiding daarvan is opgedragen. Het zwaartepunt van het onderzoek wordt of verschoven naar

7 Zie in dit verband ook M.S. Groenhuijsen, De herziening van het GVO als onderdeel van de taakverdeling tussen politie, justitie en het rechter-commissariaat, In: Afschaffing of herziening van het gerechtelijk vooronderzoek, o.r.v. C. Fijnaut en E. Kolthoff, Arnhem 1991, p. 25 t/m 32.

Commissie rapport (1990), a.w., p. 28

9 Commissie rapport (1990), a.w., p. 31. 
de terechtzitting, of naar de fase van de opsporing. In het eerste geval gaat dat ten koste van de relatief efficiënte behandeling ter terechtzitting, terwijl in het tweede geval er de facto een verschuiving van bevoegdheden plaatsvindt van de rechtercommissaris naar de politie. Beide ontwikkelingen acht de Commissie ongewenst ${ }^{10}$.

Betwijfeld kan worden of de vrees van de Commissie terecht is. Uit een oogpunt van onmiddellijkheid is het eerder zo dat het gerechtelijk vooronderzoek voor een deugdelijke rechtsbescherming van de verdachte een potentieel gevaar vormt. Bovendien is het maar de vraag of verschuiving van het zwaartepunt van het onderzoek naar de terechtzitting ten koste gaat van de effectiviteit van het strafproces in de zin van een zo kort mogelijke procedure en of het gerechtelijk vooronderzoek een buffer vormt tegen de feitelijke macht van de politie. Het zijn, zoals gezegd, met name de argumenten uit de Duitse literatuur over de discussie rond het gerechtelijk vooronderzoek die een inspiratiebron hebben gevormd bij de navolgende beantwoording van de hier gestelde vragen.

\subsubsection{Bedreiging van het onmiddellijkheidsbeginsel}

Een belangrijk argument voor de afschaffing van het gerechtelijk vooronderzoek en dat in het kader van deze studie als het belangrijkste argument kan worden gezien - werd in Duitsland gevonden in de omstandigheid dat het gerechtelijk vooronderzoek een permanent gevaar oplevert voor de realisering van het onmiddellijkheidsbeginsel. "Gerade weil die Voruntersuchung von allen Zeugenvernehmungen Protokolle eines Richters liefert, fördert sie die Gefahren, die in den gesetzlichen Ausnahmen vom Grundsatz der Unmittelbarkeit liegen. ${ }^{m 1}$ Met name het idee dat het in het belang van de rechtsbescherming van de verdachte is dat getuigen en deskundigen in het vooronderzoek door een rechter worden gehoord, is in zekere zin misleidend. Voor de verdachte gaat het er in het vooronderzoek vooral om invloed op de richting van het onderzoek te kunnen uitoefenen ${ }^{12}$. Door de wijze waarop dat onderzoek wordt uitgeoefend,

10 Commissie rapport (1990), a.w., p. 32.

11 Klaus Manke, Die gerichtliche Voruntersuchung in Frankreich, Österreich, Italien und der Schweiz; ein Vergleich im Hinblick auf dic Deutsche Strafprozessreform, München 1966, p. 275.

12 Zie hierover bijwoorbeeld Th.A. de Roos, Naar een contradictoir vooronderzoek?; Mini-instructie op verzoek van de verdachte, D\&D 1991, p. 601 en 602 . Hij wijst erop dat het perspectief van waaruit het bewijsmateriaal tijdens het voorondersoek wordt samengesteld in hoge mate de vorm en daarmee ook de inhoud daarvan bepaalt. Het opsporingsperspecticf van de opsporingsambienaar is eenzijdig en daardoor vervormend, stilerend. Als leidinggevend orgaan ontkomt het Openbaar Ministerie niet aan het f́enomeen van, wat deze auteur noemt, dubbele selectiviteit. Het onderzoek naar hetgeen heeft plaatsgevonden wordt allereerst in belangrijke mate bepaald door de wettelijke delictsomschrijvingen op grond waarvan in een zeer vroeg stadium relevante van irrelcvante informatic wordt geschift. De schaarse tijd en middelen brengen in de tweede plaats met zich dat voortdurend, zolang het onderzoek voorlduurt, keuzes moeten worden gemaakt en beperkingen mocten worden aangelegd, dic opnicuw cen selectic van informatie inhouden. 
wordt hij alleen ${ }^{i 3}$ getroffen wanneer de daarvan opgemaakte processen-verbaal ter zitting zonder meer voor het bewijs kunnen worden gebruikt ${ }^{4}$. Paradoxaal genoeg, wordt dat gevaar groter naar mate er in het vooronderzoek meer waarborgen worden geschapen voor een onpartijdig, objectief en zo mogelijk zelfs contadictoir onderzoek. Omdat effectiviteit en doelmatigheid - in de zin van een zo kort mogelijk durend proces - eveneens na te streven doelen vormen bij de inrichting van het strafproces, bestaat immers steeds de neiging om dat wat al is verricht - het horen van getuigen niet nog eens over te doen. Zeker niet, wanneer daarbij reeds de rechten van de verdediging in acht werden genomen.

\subsubsection{Contradictoir vooronderzoek versus onmiddellijk eindonderzoek}

Het is weliswaar in het belang van de rechtsbescherming van de verdachte dat getuigen en deskundigen in het vooronderzoek door een rechter worden gehoord, maar wanneer dat ten koste gaat van een onmiddellijk onderzoek ter terechtzitting, keert de in het vooronderzoek geschapen waarborg zich uiteindelijk tegen de verdachte. De verdachte is meer gebaat bij een deugdelijke controle van het bewijs door de zittingsrechter dan bij een contradictoir verhoor van getuigen en deskundigen door de rechter-commissaris tijdens het gerechtelijk vooronderzoek. Voor deze bewering zijn meerdere argumenten aan te dragen.

Zo kan worden gewezen op het feit dat de rechter ter terechtzitting het oordeel velt en het voor de verdediging dus zaak is op die oordeelsvelling invloed te kunnen uitoefenen. Staat een getuigenverklaring eenmaal op papier dan valt de geringe kwaliteit van die verklaring moeilijk aannemelijk te maken, wanneer de oorspronkelijke zegsman daarvan met die tegenspraak niet kan worden geconfronteerd. Wanneer later in het vooronderzoek andere met deze verklaring tegenstrijdige verklaringen worden afgelegd, dan heeft de verdediging de getuige daarmee niet meer kunnen confronteren.

Ook de kwestie tijd speelt hier een rol. Wanneer de gelegenheid om de getuige te (doen) ondervragen gedurende het vooronderzoek allesbepalend kan zijn, dient de verdediging voldoende tijd te worden geboden zich op de confrontatie voor te bereiden. Deze tijd is er in de meeste gevallen niet gedurende het vooronderzoe $\mathbf{k}^{15}$.

13 Dit is niet helemaal waar. Bcdacht moet worden dat nict alleen de richting waarin maar $66 \mathrm{k}$ đe wijze waarop het vooronderzoek wordt verricht wel degelijk van invloed kan zijn op de verdedigingspositie van de verdachte in ecn onmiddellijk onderzoek ter terechtzitting. Immers, de stukken van het vooronderzoek vormen het uitgangspunt van het onderzoek ter terechtzitting. De gedetailleerdheid en waarheidsgetrouwheid zijn van groot belang, voor de mate van controle die de rechter en de verdediging ter zitting kunnen uitoefenen. Hun kritische attitude wordt in belangrijke mate gevoed door wat er in de stukken staat en niet door wat er niet in de stukken staat.

14 Zie ook Klaus Manke (1966), a.w., p. 253.

15 Zic Klaus Manke (1966) a.w., p. 277. 
Daarnaast is in tegenstelling tot het gerechtelijk vooronderzoek, het onderzoek ter terechtzitting in de regel openbaar. Deze openbaarheid strekt ook tot waarborg van de verdachte, omdat van de publieke controle een stimulerende werking kan uitgaan op het nauwgezet handelen van de rechter. De getuige wordt door de openbaarheid mogelijk aangezet tot voorzichtiger en meer wararheidsgetrouwe uitspraken. In het gerechtelijk vooronderzoek worden deze waarborgen van de openbaarheid ${ }^{\text {lt }}$ gemist.

Ook de verschillen in positie en talak van de rechter-commissaris en de zittingsrechter ${ }^{17}$ pleiten uit een oogpunt van rechtsbescherming voor de verdachte uiteindelijk vớri afschaffing van het gerechtelijk vooronderzoek, wanneer handhaving daarvan betekent dat aan het onmiddellijkheidsbeginsel afbreuk wordt gedaan.

De positie van de rechter-commissaris is namelijk meer gebonden dan die van de zittingsrechter ${ }^{18}$. De rechter-commissaris oefent zijn bevoegdheden uit in het kader van het vooronderzoek. Het gerechtelijk vooronderzoek dat onder zijn leiding staat, maakt deel uit van een totale opsporing en vervolging waarvan de leiding echter berust bij de officier van justitie die onder gezag staat van de minister van justitie. De rechter-commissaris moet zich houden aan de grenzen van het onderzoek die door de vordering van de officier van justitie worden hepalald. Hij heeft geen apparaat tot zijn beschikking, maar wordt alleen hijgestaan door een griffier. Wel kan hij de politie opdrachten geven, maar daar moet men zich volgens $V$ on Meyenfeldt niet te veel van voorstellen. In de praktijk blijkt, volgens deze auteur, vaak dat de rechtercommissaris weinig contact heeft met de politie, wat mede een gevolg is van het feit dat hij zijn functie maar twee of drie jaar uitoefent. Er ontbreekt bovendien cen reguliere gezagsrelatic tot de opsporingsambtenaren, hetgeen zijn bevelshevoegdheid op voorhand problematisch maakt ${ }^{19}$. De rechter ter terechtzitting daarentegen is onathankelijk en zeltstandig.

Wat de vergelijking van hun taken betreft, kan worden opgemerkt dat de rechtercommissaris naast een rechterlijke, controlerende taak ook duidelijk een opsporings-

16 Hier moet worden toegegeven dat voor sommige verdachten de openbaarhcid meer een kwelling betekent dan een zegen. Dit laat echter onverlet dat het onderzoek ter terechtzitting om witeenlopende reden kan platstinden achter gesloten deuren (zie art. 273 Sv) terwijl hol gerechitelijk vooronderzoek per definitie niet openbaar is, ook al zou de verdachte daarop prijs stellen.

17 Zie hicrover ook: J.F. Nijboer, Kanttekeningen bij het rapport 'De bedreigde getuige', Recht en Kritick 1984, p. $901 / \mathrm{m} 93$.

18 Zie hierover A.C. 't Hart, De positic van de Rechter-Commissaris in strafzaken tussen rechtspraak en beleid, In: Strafrecht in balans, Arnhem 1983, p. $81 \mathrm{t} / \mathrm{m}$ 94; C. van Meyenfeldt, Het gerechtelijk vooronderzoek, NJB 1988, p. $1131 \mathrm{t} / \mathrm{m}$ 1134. Zie met name p. 1133 waar Von Meyenfeldt de afhankelijkheid van de rechter-commissaris ten opzichte van de officier van justitie als volgt schetst: "Uit tijdgebrek of om te voorkomen dat mensen nodeloos lang vastzitten (de OvJ kan immers niel dagvaarden gedurende een g.v.o.) worden heel wat g.v.o.'s gesloten dan wel worden verdachten weggedagvaard, hoewel de R-C best nog activiteiten had willen ondernemen."

19 C. Von Meyenfeldı (1988), a.w., p. 1133; U. Van der Pol, Schending van vormvoorschriften tijdens het gerechtelijk vooronderzoek, In: In zijn verdediging geschaad, Arnhem 1989, p. 64. 
taak heeft. De vraag is wat deze hybridische positie van de rechter-commissaris ${ }^{\infty}$ betekent voor diens onpartijdigheid en kritische distantie ${ }^{21}$.

De rechter ter terechtzitting heeft daarentegen veel duidelijker een controlerende $\operatorname{taak}^{22}$. Hij is weliswaar op zoek naar de materiële waarheid, echter binnen het kader van de door de officier van justitie opgestelde telastelegging. De rechter mag niet veroordelen voor hetgeen niet is telastegelegd $\mathrm{d}^{23}$ en dient in eerste instantie te controleren of het bewijs dat de officier van justitie voor zijn bewering dat de verdachte het hem telastegelegde feit heeft begaan, een veroordeling rechtvaardigt. Dreigt die controle voor de officier van justitie negatief uit te vallen, dan mag de rechter de officier een herkansing geven door hem in de gelegenheid te stellen bepaalde aspecten van de zaak nader te onderzoeken. Hij mag bovendien op eigen initiatief over gaan tot het horen van getuigen en deskundigen ${ }^{24}$. De rechter heeft niet alleen de taak de verdachte te beschermen, maar ook een algemeen belang te behartigen. Toch dient de rechter ervoor te waken de bewijsvoering van de officier van justitie over te nemen; dat zou leiden tot een onwenselijke rolvervaging ${ }^{25}$. Zijn taak blijft primair van controlerende aard.

20 Zie A.C. 't Hart (1983), p. 81 t/m 94; J.M. van de Laar, De rechter-commissaris: speler of scheidsrechter in het voorbereidende onderzock?, D\&D 1989, p. $379 \mathrm{t} / \mathrm{m} 390$.

21 Zic bijvoorbecld U. van der Pol (1989), a.w., p. 64: "Voor wat betreft de objectiviteit is mijn ervaring - als R-C in Amsterdam - dat de vermenging van taken niet bevorderlijk is voor de door de wetgever veronderstelde distantie en onafhankelijkheid van de $\mathrm{R}-\mathrm{C}$ ten opzichte van procespartijen. Zijn aanwezigheid bij een huiszocking en zijn vaak bestaande voorwetenschap op grond van bijvoorbeeld journaalbladen van telefoontaps kunnen cen onbevangen oordeelsvorming bij de voorgeleiding van een verdachte in de weg staan." Dat dit bij het verhoor van getuigen anders zou zijn, lijkt onwaarschijnlijk.

22 Zie nok Klaus Manke (1966), a.w., p. 227 en 228: "Das wirfl die Frage auí, ob sich die Richtereigenschaft des Untersuchungsrichters in der ihm zugewiesenen Aufgabe überhaupt voll auswirken kann. Unzählige Male ist bereitserörtert worden, obeine objektive Untersuchungsführung psychologisch eigentlich denkbar ist. (.) Wolltc man allgemein davon ausgehen, da B derienige Richter, der aktiv in die Ermittlungen eingreift, damit sogleich seine Objektivität einbüßt, so müßte dies daza führen, auch das Hauptverfahren nach den Grundsätzen desanglo-amerikanischen Akkusationsprozesses umzugestalten. Da eine solche Reform aber überwiegend abgelchnt wird, kann man bei der in Deutschland augenscheinlich herrschenden Grundauffassung auch dem Untersuchungsrichter nicht von vornherein die Objektivität absprechen. Frcilich muß man berücksichtigen, daß der Untersuchungsrichter seine Tätigkeit im Rahmen des Vorverfahrens entfaltet, in dem weniger eine bedächtige Kontrolle als ein energisches und phantasievolles Ermitteln vonnöten sind. (..) Wer aber wie der Untersuchungsrichter eine Straftat aufzuklären hat, wird von einem gewissen Zeitpunkt ab seiner Arbeit eine bestimmte Hypothese zugrunde legen, deren Richtigkeit durch das weitere Vorgehen überprüft wird. Das der Richter damit des über der Sache Stehenden aufgibt, läßt sich nicht leugnen."

23 Zie D.H. de Jong, De macht van de telastelegging in het strafproces, Arnhem 1981, p. 281.

24 A.L. Melai, Het Wetboek van Strafvordering, losbladig commentaar, Arnhem z.j., Artt. 338-344, suppl. 68 (november 1988), § 7, p. 21; J.M. Reijntjes, Strafrechtelijk bewijs in wet en praktijk, Arnhem 1980 , p. 9.

25 J.M. Reijntjes (1980), a.w., p. 80. 
Aldus kan worden vastgesteld dat ook het verschil in positie en taak van de rechtercommissaris en de zittingsrechter met zich brengt dat uit een oogpunt van rechtsbescherming, de verdachte beter gediend is bij een deugdelijke controle van het bewijs door de zittingsrechter die mogelijk ten koste gaat van een contradictoir getuigenverhoor door de rechter-commissaris tijdens het gerechtelijk vooronderzoek dan andersom.

Maar niet alleen uit een oogpunt van rechtsbescherming voor de verdachte, ook uit een oogpunt van het algemeen belang verdient een strafproces waarbij het zwaartepunt van het bewijsonderzoek ligt bij het onderzoek ter terechtzitting de voorkeur boven een strafproces waarbij dat zwaartepunt is verschoven naar het vooronderzoek. Dit om de enkele reden dat het onderzoek ter terechtzitting in beginsel openbaar is en het vooronderzoek niet. Immers, "justice must not only be done, it must also be seen to be done $e^{m .6}$. De strafrechtspleging is gebaat bij het vertrouwen van het publiek in de rechtspraak, omdat alleen met dat vertrouwen de idealen van de strafrechtspleging kunnen worden verwezenlijkt. Aan dat vertrouwen van het publiek zitten twee kanten, die op het eerste gezicht misschien tegenstrijdig lijken. Enerzijds is dat het vertrouwen van het publiek dat de schuldige zijn verdiende straf niet ontloopt. Anderzijds is dat het vertrouwen dat de verdachte en daarmee de burger niet is overgeleverd aan het willekeurige optreden van de overheid". Malar publiek vertrouwen in de rechtspralak vereist de mogelijkheid tot eigen beuordeling. En eigen beoordeling vereist openbaarheid. Echter openbaarheil krijgt pas werkelijk inhoud door middel van de onmiddellijkheid van het onderzoek ter terechtzitting ${ }^{22}$.

\subsubsection{Effectiviteit van het strafproces}

De Commissie Moons is bevreesd dat wanneer het gerechtelijk vooronderzoek wordt afgeschaft, het zwaartepunt van het bewijsonderzoek naar de terechtzitting wordt verschoven, hetgeen ten koste gaat van de relatief efficiënte behandeling ter terechtzitting. Deze vrees van de Commissie is terecht, maar zij verliest uit het oog dat het tijdverlies dat wordt geleden gedurende de fase van het eindonderzoek, (deels) kan worden teruggewonnen gedurende de fase van het voorbereidende onderzoek.

26 P. van Dijk en G.J.H. van Hoof, De Europese conventie in theorie en praktijk, 3e druk, Nijmegen 1990 , p. 360.

27 Zie A.A.G. Peters, Het rechtskarakter van het strafrecht, Deventer 1972, p. 7, die het in dit kader heeft over "policing society" en "policing the police".

28 Over de nadelen van de externe openbaarheid in het vooronderzoek schrijft Klaus Manke (1966), a.w., p. 276: "Es geht nicht an, die Beibehaltung der Voruntersuchung deshalb zu fordern, weil durch sie unter Umständen der Angeschuldigte vor der öffentlichen Hauptverhandlung bewahrt werden kann, und anderseits den Angeschuldigten schon in der Voruntersuchung einer öffentlichen Verhandlung auszusetzen." 
In Duitsland is de tijdwinst het doorslaggevende argument geweest voor de afschaffing van het gerechtelijk vooronderzoek in 1974, nadat uit onderzoek was gebleken dat uit rechtsbeschermingsoogpunt van de verdachte aan de meerwaarde van het gerechtelijk vooronderzoek onder leiding van de onderzoeksrechter ten opzichte van het opsporingsonderzoek in handen van de officier van justitie kon worden getwijfeld. De maatregel stond vooral in het kader van de "Beschleunigung des Verfahrens" Overigens dient hier niet vergeten te worden dat het gerechtelijk vooronderzoek in Duitsland altijd een louter voorbereidend karakter heeft gehad, dat aan het zwaartepunt van het bewijsonderzoek ter zitting niets afdeed. Dit feit en twijfel aan de waarde van het gerechtelijk vooronderzoek vormden het oordeel dat deze procesfase enkel leidde tot vertraging en onnodige herhaling van politieonderzoek door de onderzoeksrechter.

Maar ook in ons land, waar de 'de auditu'-rechtspraak tot gevolg heeft gehad dat ter zitting nauwelijks meer getuigen worden gehoord, wordt de klacht van dubbel werk gehoord ${ }^{30}$. Volgens Von Meyenfeldt heeft de 'de auditu'-jurisprudentie tot gevolg gehad dat zowel de officier van justitie als de verdachte zich anders op de terechtzitting voorbereiden. Vorderingen tot een gerechtelijk vooronderzoek met het verzoek om getuigen te horen zijn daarvan het gevolg. Dit kost extra tijd en betekent in veel gevallen dat de rechter-commissaris tijdens zo'n gerechtelijk vooronderzoek het opsporingsonderzoek van de politie nog een dunnetjes overdoet dan wel krachtig samenvat. Er wordt aldus volgens deze auteur ook in het Nederlandse strafproces veel dubbel werk gedaan". Dit dubhel werk zou achterwege kunnen blijven wanneer het gerechtelijk vooronderzoek wordt afgeschaft. Daarmee zou aan het tijdsverlies ten gevolge van een minder efficiënt onderzoek ter terechtzitting tegemoet kunnen worden gekomen.

Het is bovendien maar de vraag of het efficiënte onderzoek ter terechtzitting met het oog op de Europese jurisprudentie inzake het recht op het horen van getuigen, gehandhaafd kan blijven. De Commissie Moons is van oordeel dat uit deze jurisprudentie valt op te maken dat het aan de nationale autoriteiten is overgelaten te bepalen of in het strafproces het zwaartepunt ligt bij het voorbereidend onderzoek dan wel bij het onderzoek ter terechtzitting ${ }^{32}$. Gebreken in het voorbereidend onderzoek kunnen door het onderzoek ter terechtzitting worden gecompenseerd en vice versa $^{33}$. Wanneer de verdachte gedurende het gerechtelijk vooronderzoek de hem

29 Zie M. Kohlhaas, Gedanken zar Reform des Ermittlungsverfahren der StPO, Zeitschrift für Rechtspolitik 1974, p. 7 t/m 10. Zie ook A.J.M. Machiclse, Een requiem voor het gerechtelijk vooronderzock, Arnhem 1989, p. 38.

30 Zie ook Frits Abrahams, Achter gesloten deuren; De wereld van de rechter-commissaris, NRC Handelsblad van 15 januari 1994.

31 C. Von Meyenfeldt (1988), a.w., p. 1133 en 1134 . Zie ook Ch. Haffmans en C.F. Rüter, De raadsman op zijn retour, AA 1984, p. 627: "Al zal dc RC ook eigen onderzoek doen, het gvo is toch in belangrijke mate de reflexie van èn op de resultaten van het opsporingsonderzoek."

32 Commissic rapport (1990), a.w., p. 43 cn 44.

33 Commissie rapport (1990), a.w., p. 44. 
belastende getuige heeft kunnen (doen) ondervragen, is er met het oog op het EVRM geen noodzaak deze getuigen opnieuw ter zitting te horen. Volgens de Commissie dwingt art. 6 EVRM niet tot een wijziging van de wettelijke regeling van het gerechtelijk vooronderzoek.

Zoals uit hoofdstuk vier naar voren kwam, ben ik het met de Commissie niet eens. Het heeft er alle schijn van dat het door het EHRM geformuleerde uitgangspunt dat alle bewijs ter zitting in aanwezigheid van de verdachte en ten overstaan van de rechter moet worden geproduceerd, met het oog op een 'fair trial' steeds moet worden nageleefd, wanneer geen rechtvaardigende omstandigheden aanwezig zijn om dat niet te doen.

Uit oogpunt van efficiëntie ligt het meer voor de hand het zekere voor het onzekere te nemen en te kiezen voor een onmiddellijk eindonderzoek ten koste van een contradictoir vooronderzoek dan andersom.

\subsubsection{Rol van de politie in het voorbereidend onderzoek}

Over de vrees van de Commissie dat afschaffing van het gerechtelijk vooronderzoek ertoe zou leiden dat er de facto een verschuiving van bevoegdheden plaatsvindt van de rechter-commissaris naar de politie, wil ik verder kort zijn.

Valstgesteld kan worden dat ook het gerechtelijk vooronderzoek en het optreden van de rechter-commissaris in het vonronderzuek deze tendens blijkbaar niet heeft kunnen voorkomen ${ }^{35}$. Reeds herhaaldelijk is er door verschillende auteurs op gewezen, dat de rechter-commissaris de specitieke onderzoeksdeskundigheid van de politie mist en (ook) dienaangalande in een athankelijke positie verkeer ${ }^{37}$.

34 Commissie rapport (1990), a.w., p. 50. Zie ook de opmerking van de Commissie op p. 51, die uit een oogpunt van efficiēntie bevreemding wekt: "Het in de wet ter zake van de uitoefening van rechten van de verdediging, zoals het recht op ondervraging van get vigen en deskundigen à charge, opnemen van de bevoegdheid van de RC om die rechten "in het belang van het onderzoek" te beperken, leidt op zich zelf niet tot strijdigheid met enige bepaling van het EVRM. Een inbreuk op die rechten kan immers nog tijdens het onderzoek ter terechtzilting worden gecompenseerd." Zie ook Ch. Haffmans en C.F. Rüter (1984), a.w., p. 627: "Het gvo is (..) veel minder een door de RC zelf verricht gedeelte van het vooronderzoek geworden dan de makers van ons wetboek voor ogen stond. Zij wilden voorkomen, dat het gehele vooronderzoek door de OvJ en - vooral door de politic zou worden verricht (Rapport van de Commissie voor de herriening van het W.vSv., Den Haag 1913, II, p. 32). In de praktijk is het gvo, meer de door de commissie niet gewenste kant opgegaan, waarbij het onderzoek in verregaande mate door de politie wordt verricht en de resultaten aan de $\mathrm{RC}$ worden voorgelegd."

36 Zie hetgeen ik in \$2.1.2.1 opmerkte over de gebondenheid van de rechter-commissaris aan de grenzen van het gerechtelijk vooronderzoek, die door de vordering van de officier van justitie worden bepaald.

37 Zie Ch. Haffmans en C.F. Rüter (1984), a.w., p. 630: "Achtten de ontwerpers van ons wetbock zo'n 70 jaar geleden de deskundigheid van de RC nog aanmerkelijk groter dan die van de politie, thans moet men erkennen, dat in menige zaak de rollen zijn omgekeerd. Dat is niet alleen het 
Verder kan op het verschijnsel worden gewezen dat reeds nu al in vele bijzondere wetten aan opsporingsambtenaren bevoegdheden zijn toegekend die het Wetboek van Strafvordering voor de rechter-commissaris reserveert ${ }^{3 *}$.

Tenslotte kan hier nog worden gewezen op het moderne verschijnsel van de politionele bestrijding van georganiseerde criminaliteit. Het betreft hier een wijziging in de strategie van opsporen in het algemeen en meer in het bijzonder als het gaat om ernstige criminaliteit. Centraal element in dit moderne concept van upsporen is het zogenaamd pro-actief rechercheren. Het politie-apparaat functioneert daarbij in hoge mate zelfstandig. Dat roept vragen op naar de controleerbaarheid van het politieoptreden op dit terrejn*".

\subsubsection{Conclusie}

De argumentatie die de Commissie Moons aandraagt voor behoud van het gerechtelijk vooronderzoek is aanvechtbaar. Uit een oogpunt van rechtsbescherming van

gevolg van de specialisatic en toegenomen vakbekwaamheid van onze politie, maar cok van het feit, dat de RC bij zijn normale werklast - (..) - als regel de tijd niet heeft zich met dezelfde grondigheid in een ornvangrijke, wijd vertakte en complexe zaak te verdiepen als de opsporingsambtenaar, die enige maanden met de zaak bezig is."

Zie ook A.Dijkstra en A.E. Harteveld, De rechter-commissaris in het voorbereidend onderzoek; Voorstel voor een nieuwe plaatsbepaling, In: Liber Amicorum Th.W. van Veen, Arnhem 1985, p. 24 en 25; T.M. Schalken, Strafrecht als systeem van rechtsbetrekkingen; Een ontwikkeling naar evenwicht?, Arnhem 1987, p. 24 en 25; A.E. Harteveld, De rechter-commissaris in strafzaken, Arnhem 1990, p. $75 \mathrm{t} / \mathrm{m} 82$.

38 Zie A. Dijkstra en A.E. Harteveld (1985), a.w., p. 23 en 24; A.E. Hartcveld (1990), a.w., p. 94 $1 / \mathrm{m} 97$.

39 Zie G.P.M.F. Mols, Politionele bestrijding van georganiseerde criminaliteil; Enkele (kritische) kanttekeningen bij een modern verschijnsel, NJCM-bulletin 1993, p. $521 \mathrm{t} / \mathrm{m} 533$. Zie ook H.L.C. Hermans, De herriening van het gerechtelijk vooronderzoek: een visic vanuit het rechter-commissariaat, In: Afschaffing of herziening van het gerechtelijk vooronderzock?, o.r.v. C. Fijnaut $\mathrm{cn}$ E. Kolthoff, Arnhem 1991, p. 54: "Zo acht ik het onjuist dat telefoontaps en andere dwangmiddelen worden aangevraagd op basis van informatie die door inlichtingendiensten is verzameld, terwijl de precieze inhoud daarvan niet aan de $\mathrm{R}-\mathrm{C}$ wordt bekend gemaakt. Als daarmee genoegen wordt. genomen, betekent dat immers dat niet de R-C, maar de CID-chef matericel beslist of dergelijke ingrijpende dwangmiddelen worden toegepast." Zo ook Frits Abrahams, Achter gesloten deuren; De wereld van de rechter-commissaris, NRC Handelsblad van 15 januari 1994: "Een zorgelijke ontwikkeling is dat de politie steeds meer geheime-dienst-achtige activiteiten ontwikkelt, zoals het werken met infiltranten. De 'geheime politic' heeft cen grote omvang aangenomen. Wij moeten als rechter-commissaris goed controleren of de opsporing in die fase correct verloopt." In dit kader kan ook worden gedacht aan de IRT-affaire. "Het mede door gebrekkig toezicht en leiding van het openbaar ministerie op gang gebrachte proces van verzelfstandiging van het politie-apparaat leidt in combinatie met een toenemende anonimisering binnen het strafproces tot een situatie waarin het opsporingsapparaat op veel fronten vrij spel heef", aldus $\mathrm{G}$. Mols naar aanleiding daarvan in de Volkskrant van 28 maart 1994. 
de verdachte is het beter het gerechtelijk vooronderzoek af te schaffen, wanneer handhaving daarvan ten koste gaat van een onmiddellijke behandeling van het onderzoek ter terechtzitting. Ook uit een oogpunt van effeciëntie ligt het met het oog op de Europese jurisprudentie meer voor de hand te kiezen voor een onmiddellijk eindonderzoek ten koste van een contradictoir vooronderzoek dan andersom. Bovendien kan met de afschaffing van het gerechtelijk vooronderzoek een zekere tijdwinst worden geboekt in de fase van het vooronderzoek, waarmee tegemoet kan worden gekomen aan het tijdsverlies in de fase van het eindonderzoek ten gevolge van de verplaatsing van het zwaartepunt van het bewijsonderzoek. Tenslotte kan worden geconstateerd dat het gerechtelijk vooronderzoek een verschuiving van bevoegdheden en feitelijke macht van de rechter-commissaris naar de politie niet heeft kunnen tegenhouden.

Contradictoire bewijsverzameling gedurende het vooronderzoek is uit een oogpunt van rechtsbescherming zeker behartigenswaardig ${ }^{\text {to }}$, maar wanneer dit betekent dat daarmee wordt afgezien van een onmiddellijk bewijsonderzoek ter terechtzitting dan kan het gerechtelijk vooronderzoek beter worden afgeschaft.

\subsection{Het wetsvoorstel betreffende de herziening van het gerechtelijk vooronderzoek}

In navolging van het rapport van de Commissie Moons heeft de minister van justitie in zijn wetsvoorstel ervoor gekozen de opzet van het gerechtelijk vooronderzoek ongewijzigd te laten ${ }^{n}$. Het zwaartepunt van het bewijsonderzoek dient te blijven liggen waar het ligt: bij het gerechtelijk vooronderzoek.

Globaal komt het wetsvoorstel erop neer dat er allereerst, in aansluiting op de vele bijzondere wetten, ook wat betreft het algemene Wetboek van Strafvordering een overheveling plaatsvindt van bevoegdheden van de rechter-commissaris naar

40 Toch moet hierbij in acht worden genomen hetgeen KJaus Manke (1960), a.w., p. 277 en 278 schrijt: "Von größerer Bedcutung ist der Einwand, daß mit der Parteiöffentlichkeit aller Ermittlungen eine Verzögerung des Verfahrens verbunden sein werde und da $B$ die Teilnahme für alle Beteiligten eine Zeitfrage sei, Einerseits würde nämlich cine derartige Umgestaltung durch die Benachrichtigungsfristen das Verfahren in der Tat verzögern, ohne daB die Parteien anderseits wirklich die Zeit hätten, von ihren Rechten wenigstens überwiegend Gebrauch zu machen. Entscheidend spricht schließlich gegen diese Vorschläge, daß bei ihrer Verwirklichung die Hauptverhandlung vervielfältigt würde. Die eigentliche Haupt-Verhandlung würde mehr und mehr in der Voruntersuchung vorweggenommen, so daß der erste Schritt getan wäre, den Verfahrensabschnitt "Hauptverhandlung" zum endlichen Rechtstag werden zu lassen. Aus diesen Gründen scheidet eine grundlegenden Umgestaltung der Voruntersuchung in Richtung auf ein parteiöffentliches, kontradiktorisches Verfahren auf alle Fälle aus. Eine Verbesserung ist viclmehr nur im Wege einzelner Änderungen zu suchen, wie sie an andere Stelle vorgeschlagen wurden." MvT, TK 1992-1993, 23 251, nr. 3, p. 2. 
de politie ${ }^{42}$. Daarnaast wordt er een aantal bevoegdheden van de (hulp)officier van justitie losgekoppeld van het gerechtelijk vooronderzoe $k^{43}$. Verder komt het vereiste verlof of de voorafgaande machtiging van de rechtbank voor de uitoefening van een aantal door de rechter-commissaris uit te oefenen dwangmiddelen te vervallen" Tenslotte wordt de rol van de rechter-commissaris voor wat betreft het horen van getuigen versterkt. Kortom, het wetsvoorstel beoogt de wettelijke regeling in overeenstemming te brengen met de reeds bestaande praktijk, waarin de rechter-commissaris met betrekking tot zijn controle-taak steeds lijdelijker, daarentegen wat zijn opsporingstaak betreft, steeds actiever wordt. De onverenigbaarheid van de hem toebedeelde taken wordt daarmee pregnanter dan ooit. Hierdoor winnen de bovengenoemde argumenten die in Duitsland tot de afschaffing van het gerechtelijk vooronderzoek hebben geleid meer en meer aan betekenis ${ }^{45}$. In het kader van het onderzoek naar het onmiddellijkheidsbeginsel zal verder alleen op de voorgestelde wijzigingen van de regeling betreffende het horen van getuigen door de rechter-commissaris gedurende het gerechtelijk vooronderzoek worden ingegaan.

2.2.1 De wijziging van de regeling betreffende het verhoor van getuigen in het gerechtelijk vooronderzoek

De voorgestelde wijzigingen van de regeling betreffende het verhoor van getuigen (en deskundigen) in het gerechtelijk vooronderzoek, ademen allemaal de sfeer van de bedoeling het gerechtelijk vooronderzoek overeenkomstig de reeds gegroeide praktijk ook wettelijk tot zwaartepunt van het bewijsonderzoek van de procedure te maken. Het contradictoire element van het onderzoek ter zitting wordt naar voren gehaald.

42 Zie MvT TK 1992-1993, 23 251, nr. 3, \$6, p. 11. Hierbij moet gedacht worden aan de bevoegdheden ter inbeslagneming en ter betreding van plaatsen (zic voorgestelde wijziging van art. $\mathscr{6} \mathrm{Sv}$ ).

43 Zie MrT TK 1992-1993 23251 , nr. 3, $\$ 7$, p. 11 t/m 13. Hierbij moet gedacht worden aan de uitoefening van aan de rechter-commissaris tockomende bevoegdheden in spoedeisende situaties, zoals huiszoeking, schouw, beslaglegging, betreden van plaatsen en het benoemen van een of meer deskundigen. Voor deze bevoegdheden komt een verlofstelsel (zic de voorgestelde artt. 55a, 96c, 97 en 125a Sv).

44 Zie MvT TK 1992-1993, 23 251, nr. 3, \$ 8, p. 13. Denk aan de huiszoeking en het onderrock aan de persoon bij berwaar van de betrokkenen (artt. 111 lid $1 \mathrm{~Sv}, 113$ lid 1 Sv en 195 lid 2 Sv).

45 Zie ook nog het rapport van P.J.P. Lensing en J.A.W. Tak, Het vooronderzock rechisvergelijkend onderzocht, Nijmegen 1989, p. 20 over de afschaffing van het gerechtelijk vooronderzoek in Duitsland in 1974: "Vooral in de meer recente literatuur overhecrste de opvat ling dat het gerechtelijk vooronderzock als zelfstandig onderdeel van het voorbereidend onderzock zeer wel gemist kon worden en dat een rechter-commissaris met de status van rechter maar met de functie van een opsporingsorgaan niet paste in de ideeēn over de scheiding der machten." 
Hoofdregel wordt dat de raadsman hevoegd is de getuigen- en deskundigenverhoren door de rechter-commissaris bij te wonen ${ }^{\text {th }}$. Dit is slechts anders indien het belang van het onderzoek dit verbiedt (voorgesteld art. 186a lid $1 \mathrm{~Sv}$ ). De rechter-commissaris kan bovendien, wanneer hij dit in het belang van het onderzoek wenselijk acht, de verdachte in de gelegenheid stellen bij dit verhoor aanwezig te zijn (voorgesteld art. 186a lid $2 \mathrm{~Sv}$ ). De verdachte en zijn raadsman kunnen aan de rechter-commissaris vragen opgeven die zij gesteld wensen te zien (voorgesteld art. 186a lid $3 \mathrm{~Sv}$ ).

De rechter-commissaris krijgt verder alle bevoegdheden die ook de zittingsrechter heeft, zoals de bevoegdheid de getuige buiten aanwezigheid van de verdachte te ondervragen en de bevoegdheid om te beletten dat aan een bepaalde vraag door de getuige gevolg wordt gegeven (voorgesteld art. 187 lid 2 Sv respectievelijk art. $187 \mathrm{~b} \mathrm{~Sv}$ ). Hij krijgt bovendien de mogelijkheid om bij het verhoor aan een vertrouwenspersoon van een slachtoffer die als getuige wordt gehoord, dan wel aan opsporingsambtenaren toegang te verlenen (voorgesteld art. 187c Sv).

Het huidige art. 216 eerste lid Sv wordt gewijzigd in die zin dat niet enkel getuigen ten aanzien van wie de rechter-commissaris het vermoeden heeft dat deze niet ter zitting kunnen verschijnen, maar ook die getuigen ten aanzien waarvan de rechtercommissaris van mening is dat hun gezondheidstoestand door het afleggen van een verklaring ter zitting ernstig in gevaar wordt gebracht, door de rechter-commissaris dienen te worden beëdigd. Ingevolge het dienovereenkomstig te wijzigen art. 295 Sv kunnen deze beëdigde getuigenverklaringen worden beschouwd als ter zitting afgelegd en dus als geldige getuigenverklaringen ex art. 342 lid I Sv. Om de voorgestelde regeling in overeenstemming te houden met het EVRM waarschuwt de Memoric van Toelichting de rechter-commissaris dat hij ervoor zal dienen te waken, dat de verdediging haar ondervragingsrecht tijdens het verhoor ten volle kan uitoefenen, wil de beëedigde verklaring als doorslaggevend bewijs kunnen worden gebruikt. Daartoe kan hij zich zo nodig bedienen van nieuwe technische middelen zoals videoapparatuur waarmee kan worden voorkomen dat er oogcontact mogelijk is tussen de getuige en de verdachte ${ }^{47}$.

Ingevolge het voorgestelde vierde lid van art. $216 \mathrm{~Sv}$ vindt een beëdiging eveneens plaats ingeval de rechter-commissaris deze in verband met de betrouwbaarheid van de getuige nodig acht. Deze beëdiging zal niet alleen de getuige er beter van doordringen dat hij de waarheid dient te vertellen, maar zal daarnaast onder omstandigheden een verschijning van de getuige ter terechtzitting kunnen "voorkomen", aldus de Memorie van Toelichting ${ }^{48}$.

46 MvT TK 1992-1993, 23251 , nr. 3, \$ 9.13, p. 40.

47 MvT TK 1992-1993 23 251, nr. 3, §9.13., p. 41.

48 MvT TK 1992-1993, 23 251, nr. 3, \$ 9.13., p. 42. Er wordt lettelijk gesproken van "voorkomen". 
De herziening van het gerechtelijk vooronderzoek overeenkomstig het hier besproken wetsvoorstel zal tot gevolg hebben dat het zwaartepunt van het bewijsvoering in de strafrechtelijke procedure nog nadrukkelijker dan tot op heden in de praktijk reeds het geval is, komt te liggen bij het gerechtelijk vooronderzoek. Het voorgestelde vierde lid van het gewijzigde art. 216 Sv maakt maar al te duidelijk hoe de minister van justitie erover denkt: het horen van getuigen ter zitting dient zo veel mogelijk te worden voorkomen. Het EVRM biedt daar in zijn ogen ook de mogelijkheden toe. Indien de verdachte zijn verdedigingsrechten gedurende het gerechtelijk vooronderzoek voldoende heeft kunnen uitoefenen, hoeft die gelegenheid hem ter zitting niet nogmaals te worden geboden.

De rechter-commissaris draagt niet langer - zoals in de oorspronkelijke opzet van het gerechtelijk vooronderzoek - de zorg voor de wijze waarop en de richting waarin het bewijs vanwege de officier van justitie wordt verzameld, opdat deze bewijsverzameling zich leent voor een deugdelijk controle door de rechter ter terechtzitting. In de voorstellen verzamelt en controleert de rechter-commissaris het bewijs zelf. Anders en beter geformuleerd: waar in de oorspronkelijk opzet van het gerechtelijk vooronderzoek de risico's van de functievermenging voor de controlerende taak van de rechter-commissaris aanvaardbaar waren tegen de achtergrond van de uiteindelijke controle van die bewijsverzameling door de rechter ter terechtzitting, is dit nu niet meer het geval. Nu controle van het door de rechter-commissaris op vordering van de officier van justitie verzamelde getuigenbewijs door de zittingsrechter achterwege blijft, wordt ook de hybridische positie van de rechter-commissaris problematisch. Daar komt nog een complicerende factor bij. Naast zijn opsporende en controlerende taak krijgt de rechter-commissaris ook nog een verdedigende rol, wanneer de bescherming van de gezondheidstoestand van een getuige er naar zijn mening aan in de weg staat dat de verdachte zijn verdedigingsrechten onbelemmerd uitoefent. In dat geval dient het optreden van de rechter-commissaris deze tekortkoming te compenseren.

Kortom, onder omstandigheden belichaamt de rechter-commissaris drie functies in één. Dan is hij zowel vervolger - in de zin van bewijsverzamelaar -, rechter als verdediger. Ten bate van de effectiviteit van ons strafproces worden daarmee de drie vormen van controle die liggen opgesloten in het onmiddellijkheidsbeginsel prijsgegeven: openbaarheid, scheiding der machten en contradictoire procesvoering. De vraag is of het één het ander wel waard is. De geschiedenis - en met name de Duitse strafprocesgeschiedenis - lijkt te leren van niet".

49 Zie Hoofdstuk 1, \$ 6.2.3. Het onmiddellijkheidsbeginsel is mede ontstaan als een reactic op de. onverenigbaarheid van meerdere functies in handen van de inquirent (de onderzoeksrechter). 


\section{De Wet Getuigenbescherming}

In nauw verband met de plannen tot wijziging van de regeling van het gerechtelijk vooronderzoek op het gebied van het getuigenverhoor door de rechter-commissaris staat de inmiddels ingevoerde 'Wet Getuigenbescherming ${ }^{\text {'s0 }}$. Deze wet kent een lange voorgeschiedenis en is voortgekomen uit het probleem dat getuigen zich steeds vaker beroepen op vrees voor wraakneming van de zijde van de verdachte en dat niet zelden die bedreiging van de kant van de verdachte of de vrees voor represailles serieus moet worden genomen ${ }^{5}$. Om aan dit probleem het hoofd te kunnen bieden, is een wettelijke regeling gecreëerd die bedreigde getuigen bescherming beoogt te bieden. Allereerst wordt uiteengezet hoe de nieuwe wettelijke regeling inzake de bedreigde getuige er in grote lijnen uitziet en daarmee de oude wettelijke regeling in het Wetboek van Strafvordering heeft gewijzigd dan wel aangevuld. Vervolgens wordt de nieuwe regeling getoetst aan het EVRM en het onmiddellijkheidsbeginsel.

\subsection{De nieuwe regeling in grote lijnen geschetst}

Zowel de regeling van het horen van getuigen ter zitting als het horen van getuigen tijdens het gerechtelijk vooronderzoek heeft als gevolg van de wet getuigenbescherming verandering ondergaan. Daarbij wordt onderscheid gemaakt tussen het toekennen van 'beperkte' en van 'volledige' anonimiteit. In het licht van het onmiddellijkheidsbeginsel ligt het voor de hand steeds met de bespreking van de regeling betreffende het onderzoek ter terechtzitting te beginnen.

Art. $284 \mathrm{~Sv}$ is aangevuld met de mogelijkheid om aan getuigen 'beperkte anonimiteit' toe te kennen. De rechter kan bepalen dat het vragen naar een bepaald gegeven, zoals naam, voornamen, beroep of woon- en verblijfplaats, achterwege zal worden gelaten wanneer er een gegrond vermoeden bestaat dat de getuige in verband met het afleggen van zijn verklaring overlast zal ondervinden of in de uitoefening van zijn beroep belemmerd zal worden. Ingevolge het aangevulde art. $190 \mathrm{~Sv}$ komt aan de rechter-commissaris bij het getuigenverhoor tijdens het gerechtelijk vooronderzoek eenzelfde bevoegdheid toe.

50 Wet van 11 november 1993 tot wijziging van het Wetbock van Strafvordering, het Wetboek van Strafrecht en enige andere wetten (getuigenbescherming), Stb. 1993, nr. 603, ingevoerd per 1 fcbruari 1994.

51 Zie: De bedreigde getuige; Rapport van de Werkgroep 'de bedreigde getuige' van de afdeling strafrechtspraak van de Nederlandse Vereniging voor Rechtspraak / (voorzitter S. Slagter), Trema Exclusief 7, 1983 en het Rapport van de Commissie Bedreigde Getuigen / (voorritter J. Remmelink), Den Haag 1986. Zie n.a.v. dit laatste rapport J.F. Nijboer, Kanttekeningen bij het rapport 'De bedreigde getuige', Recht en Kritick 1984, p. 80 I/m 93; T.M. Schalken, Bedreigde getuige en bedrcigde rechtsstaat, Trema 1986, p. 291 t/m 303. 
Voor de toekenning van 'volledige' anonimiteit aàn bedreigde getuigen heeft de wetgever een wettelijke basis gecreëerd in (onder meer) het nieuwe art. 264 Sv. Daarin wordt bepaald dat de officier van justitie de door de verdachte opgegeven getuige kan weigeren ter zitting te dagvaarden, indien hij aan de getuige de toezegging heeft gedaan dat hij niet anders zal worden verhoord dan onder geheimhouding van zijn identiteit. Deze weigering wordt de verdachte en de rechtbank schriftelijk ter kennis gebracht. De rechter ter terechtzitting kan op deze beslissing van de officier van justitie ingevolge het gewijzigde art. $280 \mathrm{~Sv}$ slechts op twee manieren reageren. Of hij neemt een met redenen omklede beslissing dat door het achterwege blijven van het verhoor van de betreffende getuige de verdachte niet in zijn verdediging is geschaad, of hij stelt de stukken in handen van de rechter-commissaris ten einde door hem te laten bepalen of er sprake is van een bedreigde getuige. Ingevolge het nieuwe art. $136 \mathrm{c}$ Sv wordt onder een bedreigde getuige verstaan een getuige ten aanzien van wie door de rechter (lees: de rechter-commissaris in eerste instantie, dan wel de raadkamer in beroep, art. 226b Sv) bevel is gegeven dat ter gelegenheid van het verhoor zijn identiteit verborgen wordt gehouden.

De procedure volgens welke wordt vastgesteld of een getuige als hedreigde getuige kan worden aangemerkt, is geregeld in de nieuwe afdeling Vier $A$ van Titel III van het Tweede Boek, die handelt over het gerechtelijk vooronderzoek. Deze nieuwe afdeling draagt als opschrift: 'Bedreigde getuige', en bestaat uit zes artikelen (artt. $226 \mathrm{a} \mathrm{t} / \mathrm{m} 226 \mathrm{f} \mathrm{Sv}$ ).

Volgens art. 226a Sv dient de rechter-commissaris ambtshalve, op vordering van de officier van justitie dan wel op verzoek van de verdachte, diens raladsman of de getuige zelf, het bevel te geven dat ter gelegenheid van het verhoor van een getuige diens identiteit verborgen wordt gehouden indien:

a. de getuige of een andere persoon, met het oog op de door de getuige af te leggen verklaring, zich zodanig bedreigd kan achten dat, naar redelijkerwijze moet worden aangenomen, voor het leven, de gezondheid of de veiligheid dan wel de ontwrichting van het gezinsleven of het sociaal-economische bestaan van die getuige of die andere persoon moet worden gevreesd, en

b. de getuige te kennen heeft gegeven wegens deze bedreiging geen verklaring te willen afleggen.

In het andere geval wijst de rechter-commissaris de vordering of het verzoek af ${ }^{2}$. Wordt de getuige als bedreigde getuige aangemerkt dan gaat de rechter-commissaris over tot het horen van deze getuige. Daaraan voorafgaand stelt de rechter-commissaris zich op de hoogte van diens identiteit en vermeldt in het proces-verbaal dit te hebben gedaan (art. 226c Sv). Tijdens het verhoor onderzoekt de rechter-commissaris de betrouwbaarheid van de bedreigde getuige en legt daaromtrent in het proces-

52 Tegen de op basis van art. 226a Sv genomen beschikking van de rechter-tommissaris staat voor de betrokkenen ingevolge art. 226b Sv beroep open. 
verbaal rekenschap af (art. 226e Sv). De verdachte en zijn raadsman krijgen de gelegenheid de getuige te ondervragen door middel van telecommunicatie of anders door middel van het stellen van schriftelijke vragen (art. 226d Sv).

De officier van justitie die tijdens het gerechtelijk vooronderzoek van de rechtercommissaris ex art. 210 Sv het bevel krijgt om een bepaalde getuige te dagvaarden, mag weigeren dit bevel ten uitvoer te leggen indien hij van mening is dat het om een bedreigde getuige gaat en indien hij de toezegging heeft gedaan dat deze getuige niet anders dan met toekenning van volledige anonimiteit zal worden verhoord. De officier van justitie dient na schriftelijke weigering tot tenuitvoerlegging van het eerder bedoelde bevel een vordering ex art. 226a Sv in te dienen (aangevuld art. $210 \mathrm{~Sv}$ ). De verklaring van de bedreigde getuige die door de rechter-commissaris volgens de nieuwe procedure is verhoord, wordt ter zitting aangemerkt als zijnde daar afgelegd en dus voor wat betreft de bewijsregeling als een geldige getuigenverklaring ex art. 342 lid $1 \mathrm{~Sv}$ beschouwd (aangevuld art. $295 \mathrm{~Sv}$ ). Deze verklaring kan echter ingevolge het gewijzigde art. $342 \mathrm{~Sv}$ alleen tot het bewijs meewerken indien het telastegelegde feit, voor zover bewezen, betreft een misdrijf als omschreven in art. 67 , eerste lid Sv, dat gezien zijn aard, het georganiseerd verband waarin het is begaan of de samenhang met andere door de verdachte begane misdrijven een ernstige inbreuk op de rechtsorde oplevert. Volgens het nieuwe art. 344a Sv mag de rechter het bewijs dat de verdachte het telastegelegde feit heeft begaan, niet uitsluitend alannemen op grond van verklaringen van bedreigde getuigen of schriftelijke verklaringen houdende verklaringen van personen wier identiteit niet blijkt.

Wordt de getuige uiteindelijk niet als bedreigde getuige aangemerkt dan kian de rechter ter terechtzitting de officier van justitie het bevel geven deze getuige ter zitting alsnog te dagvaarden of op te roepen. Weigert de officier van justitie dit, hijvorbeeld wegens de door hem met deze getuige gemaakte afspraken, dan spreekt de rechter de niet-ontvankelijkheid uit van de officier van justitie in zijn vervolging (aangevuld art. $349 \mathrm{~Sv}$ ).

\subsection{De Wet Getuigenbescherming getoetst aan het recht op een 'fair trial'}

De vraag of Wet Getuigenbescherming in overeenstemming is met de eisen die het EVRM stelt aan een 'fair trial' valt uiteen in twee deelvragen. De eerste vraag betreft de vraag naar de toelaatbaarheid van anoniem getuigenbewijs en de tweede vraag betreft de vraag naar de rol van dit bewijs bij de bewezenverklaring. Ik behandel hier eerst - wederom en daarom kort ${ }^{30}$ - de vraag naar de toelaatbaarheid van anoniem getuigenbewijs. De vraag naar de rol van dit bewijs voor de bewezenverklaring komt daarna aan de orde. 
Iedere verdachte heeft ingevolge art. 6 EVRM recht op een 'fair trial'. Dit betekent dat iedere verdachte recht heeft op een contradictoire procesvoering en herechting door een onafhankelijk en onpartijdig gerecht. Dit betekent bovendien dat iederc verdachte het recht heeft om de hem belastende getuige te (doen) ondervragen. Eén en ander brengt met zich dat in beginsel alle (getuigen)bewijs op de terechtzitting in aanwezigheid van de verdachte moet worden geproduceerd. Onder omstandigheden echter mag de rechter zijn oordeel baseren op gereproduceerd getuigenbewijs, zonder dat daarmee in strijd wordt gehandeld met een 'fair trial'. Daarvoor gelden twee voorwaarden.

De eerste voorwarde is dat het voor de rechter noodzakelijk moet zijn om van het gereproduceerde bewijs gebruik te maken. Het ziet er naar uit dat, wat deze eerste voorwaarde betreft, de Wet Getuigenbescherming in beginsel in overeenstemming kan worden geacht met art. 6 EVRM. Wanneer getuigen weigeren ter zitting te verschijnen om daar hun belastende verklaringen af te leggen omdat zij zich bedreigd voelen, zit er voor de rechter onder omstandigheden ${ }^{54}$ niets anders op dan hun gereproduceerde verklaringen voor het bewijs te gebruiken. Maar ook anderszins is het waarschijnlijk dat het EHRM, overeenkomstig zijn oordeel in de Unterpertinger zaak ten aanzien van het verschoningsrecht ${ }^{55}$, een bepaling waarbij aan getuigen onder omstandigheden aanspraak op anonimiteit wordt toegekend als zodanig niet in strijd zal achten met art. 6 lid 1 en 3(d) van het EVRM ${ }^{56}$.

De tweede voorwaarde die echter met het oog op een 'fair trial' aan het gebruik van gereproduceerd getuigenbewijs moet worden gesteld, is dat de rechten van de verdediging in voldoende mate in acht zijn genomen. Dit betekent volgens constante jurisprudentie van het EHRM dat de verdachte gedurende enige fase van het onderzoek een adequate en passende gelegenheid moet zijn geboden de betreffende getuigen te (doen) ondervragen. Er zijn drie uitspraken van het EHRM die inzicht kunnen bieden over de vraag in hoeverre de bekendheid van de verdediging met de identiteit van de getuige noodzakelijk is voor een adequate en gepaste gelegenheid om deze

54 Omdat de getuige bijwoorbeeld is ondergedoken en dientengevolge onvindbaar is.

55 Zic Unterpertinger zaak, EHRM 24 november 1986, Series A, vol. 110, § 30: "When called by the Innsbruck Regional Court, Mrs. Unterpertinger and Miss Tappeiner refused to give evidence, as they were entitled to do by virtue of Article 152(1)(1) of the Austrian Code of Criminal Procedure. (..) As such, the provision manifcstly is not incompatible with Article $6 \$ \$ 1$ and 3(d) of the Convention: it makes allowance for the special problems that may be entailed by a confrontation between someone "charged with a criminal offence" and a witness from his own family and is calculated to protect such a witness by avoiding his being put in a moral dilemma; (..)"

56 Blijkbaar denkt de wetgever er net zo over; Zic: MvT TK 1991-1992, 22 483, nr. 3, § 5, p. 8: "In beginsel moeten alle bewijsmiddelen worden geproduceerd ten overstaan van de verdachte tijdens een openbare behandeling, waarbij de verdachte de gelegenheid moet worden geboden deze bewijsmiddelen aan te vechten. (..) Bijzondere omstandigheden, zoals de noodzaak om de anonimiteit van een bedreigde getuige te handhaven, kunnen een uitzondering op deze regel rechtvaardigen." 
te kunnen (doen) ondervragen. Dit zijn de uitspraken van het EHRM in de Kostovski zaak, de Windisch zaak en de Lüdi zaak'.

In de Kostovski zaak overwoog het EHRM: "If the defence is unaware of the person it seeks to question, it may be deprived of the very particulars enabling it to demonstrate that he or she is prejudiced, hostile or unreliable. ${ }^{15 \mathrm{I}}$ In de Windisch zaak drukt het Hof zich nog stelliger uit: "Being unaware of their identity, the defence was confronted with an almost insurmountable handicap: it was deprived of the necessary information permitting it to test the witnesse's' reliability or cast doubt on their credibility. ${ }^{130}$ In de Lüdi zaak doet het Hof aan deze stelligheid niets af ${ }^{\text {to }}$.

De minister van justitie is echter van mening dat uit de Kostovski zaak kan worden afgeleid dat de belemmering van het ondervragingsrecht van de verdediging die veroorzaakt wordt duor de onbekendheid met de identiteit van de getuige, kan worden gecompenseerd door het optreden van de rechter-commissaris. Hierover lezen we in de Memorie van Toelichting:

"Blijkens paragraaf 43 van het Kostovski-arrest kan op de hoofdregel dat een verdachte een adequate en behoorlijke gelegenheid moet worden geboden om een getuige op enig moment tijdens het strafproces te ondervragen, alleen een uitzondering worden gemaakt als er sprake is van een rechterlijke procedure en deze procedure met zodanige waarborgen is omkleed dat gezegd kan worden dat deze voldoende tegenwicht biedt. Indien de verdediging de desbetreffende getuige in verband met het verborgen houden van diens identiteit slechts in beperkte mate heeft kunnen ondervragen, kan deze taak worden overgenomen door de onafhankelijke (onderzoeks)-rechter, in dier voege dat deze in plaats van de verdediging ${ }^{11}$ de getuige rechtstreeks en onbeperkt ondervraagt. (..) Een dergelijke procedure brengt weliswaar niet mede dat er geen sprake meer is van een beperking van het recht van de verdediging op ondervraging van de getuige, doch die beperking is, juist door toedoen van de gevolgde procedure, niet meer van dien aard dat zij een schending van het bepaalde in art. 6 EVRM oplevert. Ook uit het feit dat het EHRM na te hebben vastgesteld dat de rechter ter terechtzitting geen deugdelijk onderzoek naar de betrouwbaarheid van de anonieme getuige heeft ingesteld, nagaat of de rechter-commissaris een dergelijk onderzoek heeft verricht, kan naar mijn oordeel worden afgeleid dat het EHRM in beginsel een deugdelijk onderzoek van de rechter-commissaris als een compensabele procedure aanmerkt. ${ }^{\mathrm{M2}}$

57 Zie Kostovki zaak, EHRM 21) november 1989, Series A, vol. 166; Windisch zaak, EHRM 27 september 1990, Series A, vol. 186; Ludi zaak, EHRM 15 juni 1992, Series A, vol. 238. Zie ook Hoofdstuk 4, § 3.2.4.1.

58 Kostovski zaak, EHRM 20 november 1989, Series A, vol. 166, § 42.

59 Windisch zaak, EHRM 27 seplember 1900 , Series A, vol. 186, $\$ 28$.

60) De Lüdi zaak kan hier verder buiten beschouwing blijven. In deze zaak was de verdediging immers wel op de hoogte van de identiteit van de getuige, zij het niet van diens ware identiteit. Het ging in deze zaak om het specifieke geval van de undercover-agent als getuige. Zie Hoofdstuk 4, \$ 3.2.4.1.

61 Cursivering door de auteur.

62 MvT TK 1991-1992, 22483, nr. 3, §5, p. 10. 
Eerder heb ik aangegeven dat de Kostovski uitspraak evenzeer een basis biedt voor de opvatting dat de belemmering van het ondervragingsrecht die wordt veroorzaakt door de onbekendheid van de verdediging met de identiteit van de belastende getuige, niet door het optreden van de rechterlijke autoriteiten gecompenseerd kan worden ${ }^{6}$. Het is heel goed mogelijk dat het gebruik van anonieme getuigenverklaringen als substantieel bewijs per definitie strijdig is met het recht op een 'fair trial', wegens de onmogelijkheid om in zo'n situatie de rechten van de verdediging in voldoende mate te respecteren ${ }^{64}$. Een dergelijke conclusie ligt met het oog op het recht op een 'fair trial', waarvan het beginsel van hoor en wederhoor de basis vormt, veel meer voor de hand. Als de rechter-commissaris dan wel de zittingsrechter het gebrek aan verdedigingrecht op het (doen) ondervragen van getuigen in voldoende mate zouden kunnen compenseren, waarom zou men dit recht aan de verdediging nog toekennen? Met dit argument wil ik niet ontkennen, dat ook het EHRM erkent dat een effectieve criminaliteitsbestrijding onder omstandigheden een relativering met zich brengt van uitgangspunten die aan een 'fair trial' ten grondslag liggen. Maar het Hof stelt aan die relativering duidelijk grenzen, zoals blijkt uit de volgende overweging, die eveneens afkomstig is uit de Kostovski uitspraak:

"Although the growth in organised crime doubtless demands the introduction of appropriate measures, the Government's submissions ${ }^{45}$ appear to the Court to lay insufficient weight on what the applicant's counsel described as "the interest of everybody in a civilised society in a controllable and fair judicial procedure". The right to a fair administration of justice holds so prominent a place in a democratic society, that it cannot be sacrificed to expediency. The Convention does not preclude reliance, at the investigation stage of criminal proceedings, on sources such as anonymous informants. However, the subsequent use of anonymous statements as sufficient evidence to found a conviction, as in the present case, is a different matter. It involved limitations on the rights of the defence which were irreconcilable with the guarantees contained in Article 6.".tos

Uit deze overweging van het Hof volgt mijns inziens dat de onbekendheid van de verdediging met de identiteit van de hem belastende getuige een belemmering vormt voor het aan de verdachte toekomende ondervragingsrecht, die zich niet leent voor

63 Zie Hoofdstuk 4, § 3.2.4.1.1.

64 Zie ook: A. Beyer, Kostovski treft anonicme getuige in het hart, Recht en Kritiek 1990, p. 254 t/m 256; P.M. Frielink, De anonieme getuige na Kostovski, D\&D 1990, p. $450 \mathrm{t} / \mathrm{m}$ 459; G.P.M.F. Mols, Annotatie Kostovski uitspraak, Advocatenblad 1989, p. 685t/m 690; Ties Prakken, Het OM en de anonieme getuige, NJB 1990, p. $310 \mathrm{t} / \mathrm{m}$ 312; J.F. Nijboer, Kostovski en de inquisitoire stijl van procederen, NJB 1990 . p. $593 \mathrm{t} / \mathrm{m} 595$.

65 Kostovski zaak, EHRM 20 november 1989, Series A, vol. 166, \$ 44: "The Government stressed the fact that case-law and practice in the Netherlands in the matter of anonymous evidence stemmed from an increase in the intimidation of witnesses and were based on a balancing of the interests of society, the accused and the witnesses. They pointed out that in the present case it had been established that the authors of the statements in question had good reason to fear reprisals (..)."

Kostovski zaak, EHRM 20 november 1989, Series A, vol. 166, $\$ 44$. 
compensatie door de rechterlijke autoriteiten. Daardoor is het gebruik van anonieme getuigenverklaringen als substantieel bewijs in principe in strijd met het recht op een eerlijke behandeling ex art. 6 EVRM.

\subsubsection{De rol van het bewijs voor de bewezenverklaring}

Hoewel daartoe in de opvatting van de minister tegen het licht van de Straatsburgse jurisprudentie geen noodzaak bestaat, nu in de ogen van de bewindsman het gebruik van anoniem getuigenbewijs dat wordt verzameld overeenkomstig de artt. 226a t/m e Sv geen strijd oplevert met art. 6 EVRM, is in art. 344a Sv toch bepaald dat de rechter het bewijs dat de verdachte het hem telastegelegde feit heeft begaan niet uitsluitend mag baseren op anonieme getuigenverklaringen. Heeft de minister hier op 'safe' gespeeld, of getuigt deze nieuwe bewijsminimumregel van eigen verantwoordelijkheidsbesef voor een deugdelijke strafrechtspleging? Belangrijker dan het antwoord op deze vraag is de vaststelling van het resultaat van deze bepaling. Art. 344a Sv geeft immers niet aan welke verhouding er dient te bestaan tussen het anonieme en ander bewijs. Daardoor blijft het in theorie mogelijk dat iemand wordt veroordeeld op basis van één gevonden schroevendraaier en een aantal anonieme getuigenverkla-

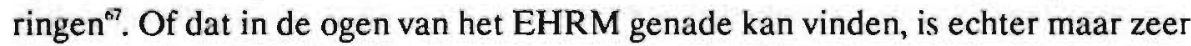
de vraag. Over de verhouding tussen het recht op een 'adequate en passende gelegenheid' tot het (doen) ondervragen van getuigen à charge en de rol die de verklaringen van de desbetreffende getuigen bij de bewezenverklaring hebben gespeeld, bestaat zoals in paragraaf 3.2.4.3 van hoofdstuk 4 werd uiteengezet ${ }^{28}$, nog veel onduidelijkheid. Het is heel goed mogelijk dat hierbij bijvoorbeeld onderscheid moet worden gemaakt tussen anonieme en niet anonieme getuigenverklaringen. Wanneer daar gemakshalve even van wordt uitgegaan, blijkt dat met betrekking tot anoniem getuigenbewijs tot op heden slechts drie - eigenlijk maar twee - uitspraken van het EHRM bestaan. In de Kostovski zaak beoordeelde het Hof een veroordeling die "in beslissen-

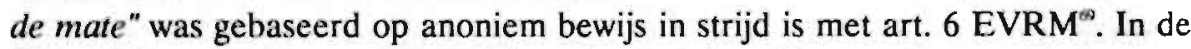
Windisch zaak was een veroordeling die "in belangrijke mate" was gebaseerd op

67 Zie Anne-Marie Wolf, Wie let er op de anonieme infiltrant?, Recht en Kritick 1993, p. 394. Zie ook MvA TK 1902-1993, 22 483, nr. 6, p. 17: "Het uitdrukkelijk stellen van de cis van substanticel andersoortig bewijs is ten aanzien van het gebruik van de anonieme getuigenverklaring die volgens de procedure van art. 226 a-e tot stand is gekomen, niet nodig geacht, omdat aan de verdediging in een eerder stadium dan het onderzock ter terechtzitting de kans op tegenspraak is geboden en in dat opzicht voldoende compensatic heeft plaatsgevonden."

68 Zo bleek dat het ontbreken van een adequate en passende gelegenheid tot ondervaging van een belastende getuige, waarvan de verklaring in de door cen opsporingsamblenaar of rechter-commissaris opgetekende vorm voor het bewijs wordı gebruikı, onder omstandigheden toch geen inbreuk vormt op art. 6 EVRM.

69 Kostovski zaak, EHRM 20 november 1989 , Series A, vol. 166, $\$ 44$. 
anonieme getuigenbewijs, hetzelfde lot beschoren ${ }^{\text {}}$. Uit deze twee zaken vloeit reeds voort dat de eis die art. $344 \mathrm{a}$ Sv aan het gebruik van anoniem getuigenbewijs stelt tegen het licht van het recht van iedere verdachte op een 'fair trial' wel eens onvoldoende zou kunnen zijn. In dit verband is ook de Lüdi zaak van belang, hoewel het in deze zaak strikt genomen niet over anoniem getuigenbewijs ging ${ }^{11}$. Daarin overweegt het EHRM namelijk: "The court notes in addition that while the Swiss courts did not reach their decisions solely on the basis of Toni's written statements, these played a part in establishing the facts which led to the conviction. ${ }^{\text {.m }}$ Het doet er blijkbaar niet toe welke rol (belangrijk dan wel ondergeschikt) het 'anonieme' getuigenbewijs voor de bewezenverklaring heeft gespeeeld. Het feit dát dit bewijs een rol heeft gespeeld, is reeds voldoende voor het stellen van de eis dat dan aan de verdediging de mogelijk moet zijn geboden tot een 'adequate en passende gelegenheid' tot ondervraging. In het licht van de Lüdi zaak krijgen de eerdervermelde overwegingen van het Hof in de Kostovski zaak en de Windisch zaak het karakter van louter feitelijke vaststellingen.

\subsubsection{Conclusie}

De Wet Getuigenbescherming is in strijd met het recht van iedere verdachte op een 'fair trial'. De onbekendheid van de verdediging met de identiteit van de hem belastende getuige vormt een belemmering voor het aan de verdachte toekomende ondervragingsrecht, die zich naar alle waarschijnlijkheid niet leent voor compensatie door de rechterlijke autoriteiten. Daardoor is het gebruik van anonieme getuigenverklaringen in ieder geval als substantieel bewijs maar misschien zelfs als bewijs 'zonder meer' in strijd met het recht op een eerlijke behandeling ex art. 6 EVRM. De Wet Getuigenbescherming legaliseert echter ex art. 344a Sv de mogelijkheid tot veroordeling op basis van hoofdzakelijk anoniem getuigenbewijs.

\subsection{De Wet Getuigenbescherming en het onmiddellijkheidsheginsel}

Zoals reeds eerder opgemerkt, sluit de Wet Getuigenbescherming nauw aan bij de voorgestelde wijzigingen van de regeling van het gerechtelijk vooronderzoek voor wat betreft het horen van getuigen door de rechter-commissaris. Ook bij die voorstellen werd duidelijk dat de rechter-commissaris onder omstandigheden bevoegd wordt de rol van de verdediging over te nemen, namelijk wanneer hij van mening is dat de gezondheidstoestand van de getuige door het afleggen van een verklaring ter

70 Windisch raak, EHRM 27 september 1990, Sreis A, vol. 1\$, \$ 31.

71 Zie hoofdstuk 4, $\$ 3.2 .4 .1$ : De undercover-agent Toni kon niet worden beschouwd als ecn anonicme getuige in de strikte $z$ in des woords.

72 Lüdi zaak, EHRM 15 juni 1992, Series A, vol. 238, § 47. 
zitting ernstig in gevaar wordt gebracht (voorgestelde wijziging van art. $216 \mathrm{~Sv})^{3}$. Het betreft dan geen anonieme getuigen, maar bijvoorbeeld slachtoffer/getuigen ${ }^{74}$.

Als gevolg van de Wet Getuigenbescherming wordt die rol van de rechter-commissaris verder uitgebreid ${ }^{7}$. De situaties waarin de rechter-commissaris zal gaan optreden als bewijsverzamelaar, verdediger en rechter tegelijk, worden aanzienlijk verruimd. De bescherming van getuigen gaat ten koste van het onmiddellijkheidsbeginsel en daarmee ten koste van de drie vormen van controle die liggen opgesloten in het onmiddellijkheidsbeginsel: openbaarheid, scheiding der machten en contradictoire procesvoering. Op het punt van de controle van de zittingsrechter op de bewijsverzameling gaat de Wet Getuigenbescherming in vergelijking tot de voorgestelde wijziging van de regeling van het gerechtelijk vooronderzoek voor wat betreft het horen van getuigen door de rechter-commissaris zelfs nog verder. Waar de zittingrechter niet gebonden is aan het oordeel van de rechter-commissaris dat de gezondheidstoestand van de niet-anonieme getuige door het afleggen van een verklaring ter zitting ernstig in gevaar gebracht wordt (voorgestelde wijziging van art. $216 \mathrm{~Sv}$ ), is hij dat in geval van een bedreigde getuige wel. Met andere woorden, behoudt de zittingrechter de mogelijkheid om in geval van niet-anonieme getuigen recht te doen aan het onmiddellijkheidsbeginsel, in geval van een anonieme getuige is hem iedere mogelijkheid onhouden de getuige zelf te horen (aangevuld art. $315 \mathrm{~Sv})^{7 \mathrm{t}}$. De autonoom rechterlijke functie komt nu eerst goed onder druk te staln". Het enige dat de rechter overblijft, is te beslissen of hij zijn overtuiging mede wenst te baseren op de door de rechter-commissaris onvolledig gereproduceerde verklaringen ${ }^{\text {is }}$ van een anonieme

73 Zie Voorstel van wet, TK 1992-1993, 23 251, nrs. 1-2, p. 17.

74 Zie CJ. van Bavel en R.P.G.L.M. Verbunt, Slachtoffer/getuige in zedenzaken en verhoor ter zitting, NJB 1990, p. 1399 I/m 1404; H.J. Donker en A.C. Maan, Slachtoffers van zware criminaliteit als getuige ter terechtzitting. NJB 1991, p. 141 l/m 142; H.J. Donker en G. Smit, Slachtoffers vrouwenhandel verdienen meer bescherming, APB 1900, p. $344 \mathrm{t} / \mathrm{m} 348$.

Zie in dit verband ook: J.F. Nijboer, De anonieme informant als getuige in het strafprocesrecht, Recht en Kritick 1980, p. 428 dic erop wijst dat de beleidsvrijhcid van de rechter-commissaris om uit te maken of cen bepaalde getuige anoniem blijft op gespannen voet staat met de taak en positic van de rechter-commissaris in het gerechtelijk vooronderzock.

Zie ook de opmerking van het kamerlid Van den Berg (SGP) tijdens de parlementaire behandeling van het wetsvoorstel getuigenbescherming in de Tweede Kamer, vergadering van 9 juni 1993, TK 76, p. 76-5524: "Gevolg van het voorstel is, dat de zittingsrechter iedere mogelijkheid wordt onthouden, de getuigen zelf te horen. Nu schort het bij ons niet bij voorbaat aan vertrouwen in de rechtercommissaris. De vraag is echter wel, hoe hij zijn bevoegdheden gaat uitocfenen. Hij geeft volgens de wet weliswaar leiding aan het onderzock, maar hoe: vaak doct hij zelf dat onderzoek? Is de praktijk nict zo, dat hij steeds vaker slechts een decl van dat onderzock zelf doet."

77 Vgl. Minderheidsrapport van A.H.J. Swart bij het Rapport van de Commissie bedreigde getuigen / (voorz: J. Remmelink), Den Hāag 1986, p. 92.

78 Namelijk zodanig en slechts voor zover weergegeven dat daaruit de identiteit van de getuige nict blijkt. Zie art. $226 i$ Sv. 
getuige $^{x}$. Wanneer het gaat om zeer ernstige vormen van criminaliteit wordt het voor de rechter wel erg moeilijk om principieel te blijven.

\subsubsection{De belangenafweging door de minister van justitie}

Volgens de minister is het onmiddellijkheidsbeginsel geen beginsel met absolute gelding. Tijdens de parlementaire behandeling van het wetsontwerp getuigenbescherming liet hij zich hierover als volgt uit:

"Natuurlijk, zou het mooi zijn als iedere getuige bereid zou zijn op de openbare terechtzitting. een belastende verklaring af te leggen. Niettemin moet worden vastgesteld dat van een dergelijke bereidheid in het kadervan de vervolging van zware georganiseerde criminaliteit niet zonder meer kan worden uitgegaan. Dat geldt ook voor de andere vormen van criminaljteit, waarover ik eerder heb gesproken. Ook dient als ervaringsgegeven teworden aanvaard dat voor het afdwingen van de aanwezigheid en van het afleggen van een verklaring aan het justitieel apparaat slechts beperkte middelen ten dienste staan. Tegen een getuige die zich onvindbaar houdt of die op het beslissende moment door vergeetachtigheid of vaagheid van herinnering wordt geplaagd, kunnen geen effectieve maatregelen worden genomen. Ook het uiterste middel, het instellen van een vervolging tegen degene die zich opzettelijk aan zijn verschijningsplicht onttrekt op de voet van art. 192 van het Wetboek van Strafrecht, of het in gijzeling nemen van degene die zonder wettige grond weigert een verklaring af te leggen - op grond van art. 289 van het Wetboek van Strafvordering - kan niet bevverkstelligen dat de belastende verklaring uiteindelijk in de oorspronkelijke strafzaak wordt afgelegd. Wie uitgaat van het onmiddellijkheidsbeginsel gaat uit van de irreële situatie dat de get uige alleen oog heeft voor het belang van de waarheidsvinding en bereid is daarvoor bedreigingen te trotseren. Zo werkt dat niet. Het is duidelijk dat politiebescherming aan zo'n getuige ook niet onbeperkt kan worden gegeven en dat bedreigingen uit het criminele milieu nu eenmaal niet zullen worden genegeerd door iedereen onder alle omstandigheden."

\subsubsection{Verkeerde methode}

De minister van justitie heeft gelijk dat het onmiddellijkheidsbeginsel uiteindelijk valt of staat met de bereidheid van getuigen om op zitting te verschijnen en daar

79 En zelfs dat ging sommigen te ver. Zie bijvcorbeeld hetgeen het kamerlid Soutendijk-van Appeldoorn (CDA) opmerkte tijdens de parlementaire behandeling van het wetsvoorstel get uigenbeschèrming, vergadering van 9 juni 1993, TK 76, p. 76-5525: "In het voorstel krijgt de rechter een grote marge om de anoniem afgelegde verklaring als bewijs al dan nict te aceepteren. Dat vergroot onzes inziens de onzekerheid voor het openbaar ministerie over de mogelijkheid om de zaak met zo'n anonieme getuige bewijsrechtelijk rond te krijgen. Het risico bestaat dat de zaak om die reden niet wordt aangebracht dan wel dat hij mislukt, omdat de rechter uiteindelijk het bewijsmateriaal dat cruciaal is voor de veroordeling niet accepteert. Daarom vinden wij en is hel ook zaak dat de marge van de rechter zo zorgvuldig mogelijk is omlijnd." 
an belastende verklaring af te leggen. En het is waar dat de algemene bereidheid om dat te doen, afneemt. De gedachte dat het een burgerplicht is om aan de warheidsvinding mee te werken, spreekt steeds minder aan. Dat is zeer zeker een niet te onderschatten probleem. De norzaak van dat probleem ligt volgens de minister in de toenemende bedreiging van potentiële getuigen. De vraag is of dat wel zo is ${ }^{*}$. Maar zelfs al wordt er van uit gegaan dat bedreiging inderdaad de oorzaak is van de afname van de bereidheid van getuigen om ter zitting te verschijnen en te verklaren, dan nog moet worden afgevraagd of de oplossing die de minister voor het probleem aandraagt niet erger is dan de kwaal. Eén en ander komt er immers op neer dat de weigering om te voldoen aan zijn burgerplicht bestreden wordt met het onder omstandigheden afschaffen van die burgerplicht. Anders gezegd, de minister bejegent het probleem om in de praktijk recht te doen aan het onmiddellijkheidsbeginsel met het voorstel om dan maar géén recht te doen aan dat beginsel. Het is, aldus de bewindsman, onacceptabel dat een verdachte vrijuit gaat als gevolg van het feit dat getuigen niet ter zitting durven te verschijnen omdat zij zich bedreigd voelen ${ }^{* 1}$. De filosofie van de minister is juist, maar zijn methode deugt niet. Door namelijk de bescherming van getuigen te bewerkstelligen ten koste van het onmiddellijkheidsbeginsel, verliest de minister uit het oog dat de zelfstandige controle van het bewijs door de zittingsrechter in een contradictoire 'setting' nu net bedoeld is om de werkelijk schuldige te straffen maar tegelijkertijd beoogt te voorkomen dat niet schuldigen veroordeeld worden" $n^{4}$. Liteindelijk is dat het doel van het strafproces en de bescherming van getuigen dient daarom overeenkomstig dat doel te geschieden. Dat zou bijvoorbeeld allereerst kunnen geschieden door middel van de strafhaarstelling van getuigenbedreiging voorzien van zware sancties en gecombineerd met een streng vervolgingsbeleid ${ }^{\mathrm{k}}$. Het gaat immers om zeer laakbare gedragingen die een ernstig

80 Opvallend is dat de minister ondanks herhaald verzock van de Kamer niet in staat was een inventarisatie te overhandigen van de mate waarin het verschijnsel van de bedreigde getuige zich voordoet. Zie MvT TK 1992-1993, 22 483, nr. 6, p. 4; Parlementaire beraadslaging van het wetsvoorstel getuigenbescherming, vergadering van 10 juni 1993 , TK 77, p. 77-5604. Men kan zich afvragen of het gesignaleerde probleem geen dicperc oorzaken heeft zoals het verdwijnen van de onderlinge solidariteit in de samenleving. Maar ook de door de media en politiek zelf gestimuleerde gevoelens van onveiligheid en angst moeten mijns inziens als belangrijke bewecgredenen nict worden onderschat.

81 Zie parlementaire behandeling van het wetsvoorstel getuigenbescherming in de Tweede Kamer, vergadering van 10 juni 1993 , TK 77 , p. $77-5604$.

82. Dit werd ook opgemerkt door het kamerlid Brouwer (Groen Links) tijdens de parlementaire behandeling van het wetsvoorstel getuigenbescherming in de Tweede Kamer, vergadering van 9 juni 1993 , TK 76, p. 76-5526 en 76-5527; vergadering van 10 juni 1993 , TK 77, p. 77-5604.

83 Ook de wet getuigenbescherming voorziet in een strafbaarstelling. Zie het nieuwe art. $285 \mathrm{Sr}$ : "Hij die opzettelijk mondeling, door gebaren, bij geschrift of afbeelding zich jegens een persoon uit, kennelijk om diens vrijheid om naar waarheid of geweten ten overstaan van een rechter of ambtenaar een verklaring af te leggen te beïnvloeden, terwijl hij weet of ernstig reden heeft te vermoeden dat die verklaring zal worden afgelegd, wordt gestraft met gevangenisstraf van ten hoogste vier jaren of geldboete van de vierde categorie." 
gevaar voor de rechtsstaat opleveren en om die reden niet kunnen worden getolereerd. Met name een vervolgingsheleid waaruit blijkt dat dit soort gedragingen worden gezien als een ernstiger bedreiging van de rechtsstaat dan de strafbare gedraging zelf waarvoor vervolgd wordt, zou mogelijk kunnen bijdragen aan het terugwinnen van het publieke vertrouwen in het justitiële apparaat als bescherming tegen de criminaliteit. Daarnaast zou bijvoorbeeld ook iets kunnen worden gedaan aan de rechtspositie van getuigen onder meer in de vorm van rechtsbijstand ${ }^{s}$.

\subsubsection{Ongewenste gevolgen}

De bestrijding van bedreiging van getuigen als één van de oorzaken van het gebrek aan bereidheid van getuigen om ter zitting te verschijnen en te verklaren, moet zeker ter hand worden genomen, maar niet op de wijze van de Wet Getuigenbescherming. Afgezien van de meer principiële kritiek bestaat namelijk bovendien het gevaar dat de Wet Getuigenbescherming gevolgen zal kennen, die zelfs de minister niet heeft gewild.

Buiten kijf staat immers dat het gebruik van anonieme getuigenverklaringen voor het bewijs uitzondering dient te blijven. "Van belang is dat we het gebnik onder bepaalde voorwaarden - ik onderstreep dat nogmaals - onvermijdelijk achten, en slechts dan, en onder die voorwaarden, de mogelijkheid daartoe willen openen", zo verklaarde de minister in de Tweede Kamer ${ }^{85}$. Onzeker is of aan de in de wet opgesloten belofte dat het gebruik van anonieme getuigenverklaringen voor het bewijs zoveel mogelijk wordt vermeden, gestand kan worden gedaan ${ }^{8}$.

Geconstateerd moet worden dat het criterium aan de hand waarvan de rechtercommissaris moet vaststellen of er sprake is van een bedreigde getuige nogal vaag is: "dat naar redelijkerwijze moet worden aangenomen, voor het leven, de gezondheid of de veiligheid dan wel de ontwrichting van het gezinsleven of het sociaal-economische bestaan van die getuige of een andere persoon moet worden gevreesd" (art. 226a Sv). De Memorie van Toelichting noemt hierbij als voorbeelden: gijzeling, vrijheidsberoving, vernieling of beschadiging van gezinswoning, bedrijf, kantoor of winkel, stelselmatige intimidatie van clientèle dan wel openbaarmaking van gegevens die een ontslag uit de dienstbetrekking tot gevolg kunnen hebben of openbaarmaking van gegevens

84 Zie hierover bijvoorbeeld de suggesties die Mols in verschillende publicaties heef gedaan: G.P.M.F. Mols, Getuigen in het voorbereidend onderzoek in strafzaken, In: Schaduwen vooruit, Arnhem 1992, p. 47 t/m 78; G.P.M.F. Mols, Heren, zien en verklaren; Over getuigen en hun verhoor in het Nederlandse strafproces, In: Goed gezien?; Problemen bij identificatiemethoden in strafzaken, Arnhem 1993, p. 17 t/m 32; G.P.M.F. Mols, Getuigen en strafzaken, Nieuwenhoflezing Vl, Deventer 1993.

85 Parlementaire behandeling van het wetsontwerp getuigenbescherming, vergadering van 10 juni 1993, TK, p. 77-5603.

86 Zie ook het NJCM-commentaar op het wetsontwerp getuigenbescherming, NJCM-bulletin 1992, p. $836 \mathrm{t} / \mathrm{m} 846$. 
zoals homoseksuele gerichtheid, biologische afstamming dan wel incestueuze of buitenechtelijke relaties ${ }^{k}$. Deze voorbeelden lijken weliswaar concreet en toetsbaar, maar het probleem is dat de vrees voor de genoemde gebeurtenissen vooral zal worden bepaald door de getuige zelf. Het gevaar hestaat dat uiteindelijk de kans op beschadiging van de psychische gezondheid van de getuige allesbepalend gaat worden. Dit kan een aanzuigende werking tot gevolg hebben van getuigen die verklaren zich hedreigd te voelen ${ }^{88}$.

Daarbij dient tevens bedacht te worden dat de vraag of sprake is van een bedreigde getuige los staat van de vraag of de verklaring van een bedreigde getuige overeenkomstig het gewijzigde art. 342 Sv voor het bewijs mag worden gebruikt. Immers, de vraag of een getuige zich zodanig bedreigd kan achten dat, naar redelijkerwijs moet worden aangenomen, voor aantasting van zijn functioneren moet worden gevreesd, is niet gerelateerd aan de ernst van het strafbare feit waarover de getuige een verklaring zou kunnen afleggen. Dit kan ertoe leiden dat het getuigenbewijs voor een veroordeling van strafbare feiten die, voor zover bewezen, niet vallen onder die genoemd in art. 67 lid 1 Sv voor een belangrijk deel onbruikbaar wordt. In dat geval mogen de anonieme getuigenverklaringen, die door de rechter-commissaris conform de nieuwe procedure ex artt. 226a $\mathrm{t} / \mathrm{m} 226 \mathrm{f} \mathrm{Sv}$ zijn verzameld en opgetekend in een proces-verbaal, immers alleen tot het bewijs meewerken indien de bewijsbeslissing in belangrijke mate steun vindt in andersoortig bewijsmateriaal én de verdachte 'vergeten' is op enig moment in het geding de wens te kennen te geven om de betreffende getuige te (doen) ondervragen'.

\subsection{Conclusie}

De Wet Getuigenbescherming heeft tot gevolg dat de rechter-commissaris onder omstandigheden dient op te treden als bewijsverzamelaar, verdediger en rechter tegelijk. De zittingrechter wordt, voor zover het bedreigde getuigen betreft, buiten spel gezet. De wet biedt hem geen mogelijkheid de bedreigde getuige zelf te horen. De bescherming van getuigen gaat ten koste van het onmiddellijkheidsbeginsel en daarmee ten koste van de drie vormen van controle die liggen opgesloten in het

87 MvT TK 1991-1992, 22483 , nr. 3, \$ 7.4., p. 19.

88 Zie ook hetgeen Korthals (VVD) opmerkte tijdens de parlementaire behandeling in de Tweede Kamer, HTK vergadering van 10 juni 1993, TK 77, p. 77-5610.

89 Zie het gewijzigde art. 344 lid 3 Sv dat luidt: "Een schriltelijk bescheid houdende de verklaring van een persoon wiens identiteit niet blijkt, kan alleen medewerken tot het bewijs dat de verdachtc het telastegelegde feit heeft begaan, indien ten minste aan de volgende voorwaarden is voldaan: a. de bevijsbeslissing vindt in belangrijke mate steun in andersoortig bewijsmateriaal, en b. door of namens de verdachte is niet op enig moment in het geding de wens te kennen gegeven om de in de aanhef bedoelde persoon te ondervragen of te doen ondervragen." 
onmiddellijkheidsbeginsel: openbaarheid, scheiding der machten en de contradictoire procesvoering.

De nieuwe regeling in strijd met art. 6 EVRM. Bovendien is de invoering daarvan te betreuren wegens de dreigende aanzuigende werking op getuigen, die anders waarschijnlijk wel ter zitting zouden zijn verschenen. Daarnaast bestaat het gevaar dat in minder ernstige zaken het getuigenbewijs verloren gaat.

Bescherming van bedreigde getuigen is zeker een zaak waarvoor de overheid zich dient in te spannen, maar niet op de wijze waarop dit via de Wet Getuigenbescherming gebeurt.

\section{De verkorte procedure voor bekennende verdachten}

Het laatste plan dat in dit hoofdstuk besproken wordt op zoek naar de opvattingen van onze huidige wetgever over het belang van het onmiddellijkheidsbeginsel voor een goed ingericht onderzoek ter terechtzitting, is het plan om te komen tot een verkorte procedure voor bekennende verdachten ${ }^{\infty}$. Dit plan verkeert momenteel in het stadium van een herzien concept wetsvoorstel dat is vervaardigd namens de minister van justitie". Aan dit herziene concept ging een eerder concept vooraf evenals een rapport van de Commissie Moons, die door de minister was verzocht advies uit te brengen over de functie van vormvoorschriften uit het Wetboek van Strafvordering en de sanctionering bij overtreding daarvan. In het kader van die taakopdracht werd door een subcommissie van de Commissie Moons een rapport opgesteld waarin werd voorgesteld een verkorte procedure voor bekennende verdachten in het wetboek op te nemen ${ }^{92}$. Aan dit rapport van de Commissie Moons en ook aan het eerste concept wetsvoorstel van de minister is van uiteenlopende kanten uit de wetenschap en praktijk kritische aandacht besteed". Het laatste concept van

90 Verkorte strafprocedures zijn in de continentaal Europese systemen van strafiechtspleging nict onbekend. Zie C.F. Mulder en P.J.P. Tak, De bekennende verdachte; Een onderzock naar de procedure voor de bekennende verdachte in het Deense en Noorse (straf-)procesrecht, Arnhem 1993.

91 De ministerraad heeft op 18 maart 1994 ingesternd met een voorstel van deze strekking. Zie NJB 1994, p. 491.

92 Zie het Rapport van de Commissie Herijking Wetbeek van Strafvordering tot aanvulling van het Wetbock van Strafvordering met voorzicningen ten behoeve van een vereenvoudigde procedure in strafzaken, november 1992, In: Rapporten herijking strafvordering 1989-1992, o.r.v. G.J.M. Corstens, Arnhem 1993, p. $183 \mathrm{t} / \mathrm{m}$ 205. Zie ook p. 6 en 7.

93 Zie in dit verband H. de Doelder, A.C. " 1 Hart, Aparte procedure voor bekennende verdachten?, NJB 1992, p. 629 t/m 630; D.M.H.R. Garé, De enkele bekentenis als uiisluitend bewijs in strafzaken, NJB 1992, p. 631 t/m 633; T. Prakken, Naar een tweesporig strafproces?, NJB 1992, p. $12941 / \mathrm{m}$ 1300. Deze drie artikelen verschenen reeds voor het uitkomen van het rapport van de Commissie Moons, maar reageerden op geruchten over de strekking van het komende rapport. Zie verder: N. Jörg, Een vereenvoudigde procedure in strafzaken; Accusatoire tendenties, NJB 1993, p. 199 t/m 205; D.M.H.R. Garé, Bekennende verdachten; De plannen rond de vereenvoudigde procedure 
het wetsvoorstel van de minister sluit nauw aan hij de voorstellen van Commissie Moons in haar rapport. Alleen dit laatste concept wetsvoorstel zal hier behandeld worden.

Wederom is ailereerst in beeld gebracht hoe de voorgestelde verkorte procedure eruit ziet. Vervolgens worden de argumenten besproken die zijn aangedragen om een verkorte procedure voor bekennende verdachten te creëren. Dan wordt kort stil gestaan bij de overeenstemming van de nieuwe procedure met de eisen die het EHRM stelt aan een 'fair trial'. Ten slotte komen de gevolgen van het vereenvoudigde proces voor het onmiduellijkheidsbeginsel en de wadrdering van die gevolgen aan de orde.

\subsection{De voorgestelde regeling}

In het Tweede Boek van het Wetboek van Strafvordering wordt een nieuwe Titel VI A ingevoegd, die luidt: 'Bijzondere hepalingen houdende een vereenvoudigde procedure'. Deze Titel zal bestaan uit vijf nieuwe artikelen (artt. 366a t/m 366e Sv). Uit die artikelen en in samenhang met de Memorie van Toelichting komt globaal ${ }^{\text {at }}$ het volgende beeld naar voren:

Voor de aanvang van de terechtzitting dient de zittingsrechter na te gaan welke zaken geschikt zijn voor een berechting volgens de vereenvoudigde procedure. Dat zijn die zaken waiarbij de rechter uit de processtukken heeft kunnen opmaken dat de verdachte het feit bekent en hijzelf bovendien van mening is dat aan de voorwaarden voor strafoplegging - in het bijzonder de bewezenverklaring - is voldaan. Acht de rechter een zaak geschikt voor vereenvoudigde afdoening dan dient hij, nadat de officier van jusitie cle zaak heeft voorgedragen, de verdachte te vragen of hetgeen hem door de officier van jusitie is verweten, klopt. Beantwoordt de verdachte deze

in strafzaken, NJB 1993, p. 409 t/m 414; A.A. Franken, De inzet van het geding; Een vereenvoudigde procedure in strafzaken voor bekennende verdachten, D\&D 1993, p. $202 \mathrm{t} / \mathrm{m}$ 224. Zie ook de gebundelde bijdragen, In: Een afzonderlijke procedure voor bckennende verdachte?, o.r.v. M. Hildebrandt e.a., Arnhem 1993.

94 De eveneens op de vereenvoudigde procedure van toepassing zijnde voorgestelde regeling inzake het verkorte proces-verbaal van de zitling en het verkorte vonnis blijven hier buiten beschouwing. Niet omdat deze voorstellen in het licht van het onmiddellijkheidsbeginsel niet relevant zouden zijn. Bedenk dat de kennisneming vanaf de publicke tribune van een strafproces dat gevoerd wordt overeenkomstig de eisen van het onmiddellijkheidsbeginsel, nog geen inzicht gecft in de waardering van het bewijs door de rechter. Publicke controle op het functioneren van de rechter vereist daarom dat deze zijn beslissing uitvoerig motiveert en openbaar maakt. De eerder bedoelde voorstellen blijven buiten beschouwing uit een oogpunt van noodzakelijke beperking en omdat ook zonder de bespreking daarvan voldoende aan het licht komt hoe onze huidige wetgever denkt over het belang van het onmiddellijkheidsbeginsel voor een goed ingericht onderzoek ter terechtzitting. Zie over de voorgestelde regeling inzake het verkorte proces-verbaal van de zitting en het verkorte vonnis: H.C. Wiersinga, Gēheimzinnig of zinvol?, In: Een afzonderlijke procedure voor de bekennende verdachte?, o.r.v. M. Hildebrandt e.a., p. $117 \mathrm{t} / \mathrm{m} 121$. 
vraag bevestigend dan zal de rechter de verdachte uitleggen dat als hij volhardt in zijn bekentenis en voornemens is geen verweer of geen ander verweer vour te dragen dan een verweer dat betrekking heeft op de op te leggen straf of maatregel, het onderzoek ter terechtzitting zal worden gericht op de vraag welke straf of maatregel moet worden opgelegd (voorgesteld art. 336a lid 2 en $3 \mathrm{~Sv}$ ). Door te verklaren dat hij het telastegelegde feit heeft begaan en geen verweer of geen ander verweer dan een strafmaatverweer zal voeren, bepaalt de verdachte in belangrijke mate zijn procespositie. Hij ziet daarmee af van een onderzoek ter terechtzitting naar de vraag of het feit bewezen is, strafhaar is en of hijzelf strafbaar is. De rechter volstaat met een mededeling van de korte inhoud van de stukken en bespreekt de stukken die van belang zijn voor de op te leggen straf of maatregel (voorgesteld art. 366 b Sv). Eventueel hoort hij getuigen en deskundigen wier verklaring voor bepaling van de juiste sanctie of maatregel van belang kunnen zijn.

De rechter kan ambtshalve of op vordering van de officier van justitie bepalen dat de vereenvoudigde procedure buiten toepassing blijft. Hij is hiertoe verplicht indien de verdachte in de loop van het onderzoek terugkomt op zijn bekentenis of alsnog andere verweren gaat voordragen dan die met betrekking tot de op te leggen straf of maatregel (voorgesteld art. 366c Sv).

Aan het Derde Boek van het Wetboek van Strafvordering wordt eveneens een nieuwe Titel toegevoegd. Deze Titel II A draagt als opschrift: 'Hoger beroep volgens de vereenvoudigde procedure'. Daarin wordt bepaald dat de bepalingen van de vereenvoudigde procedure in hoger beroep van overeenkomstige toepatsing zijn, indien die procedure ook al in eerste aanleg werd gevoerd of wanneer de verdachte. dat als zijn wens te kennen geeft (voorgesteld art. $426 \mathrm{~g} \mathrm{~Sv}$ ).

Indien berechting heeft plaatsgevonden volgens de vereenvoudigde procedure kan alleen beroep in cassatie worden ingesteld tegen de heslissing omtrent de opgelegde straf of maatregel (voorgesteld gewijzigd art. $429 \mathrm{~Sv}$ ).

\subsection{De argumenten om te komen tot een verkorte procedure}

De minister van justitie sluit zich in het herziene concept wetsvoorstel geheel aan bij de argumenten die door de Commissie Moons zijn aangedragen om te komen tot een vereenvoudigde procedure voor bekennende verdachten.

Het eerste en belangrijkste argument van de Commissie is dat een hoogwaardig procesrecht moet zijn gericht op de inzet van het geding. Het Wetboek van Strafvordering gaat er van uit dat de inzet van het strafproces wordt bepaald door de vraag of de verdachte het strafbare feit heeft begaan en of het feit en de dader strafbaar zijn. Dit is volgens de Commissie niet meer in overeenstemming met de praktijk. Die laat immers zien dat de grote meerderheid van de verdachten deze vragen zonder meer bevestigend beantwoordt. Dit heeft feitelijk tot gevolg gehad dat in die gevallen de inzet van het geding wordt gevormd door de vraag welke straf of maatregel moet 
worden opgelegd. Met het oog op de rechtszekerheid (art. $1 \mathrm{~Sv})^{\text {os }}$ dient de wettelijke regeling met deze praktijk in overeenstemming gebracht te worden, aldus de Commis$\operatorname{sic}^{\infty}$.

1)e hier weergegeven redeneertrant van de Commissie is kenmerkend en opvallend. De Commissie constateert een discrepantie tussen de theorie en de praktijk en verbindt daaraan de conclusie dat met het oog op het legaliteitsbeginsel de theorie dan maar moet worden aangepast aan de praktijk. Was het niet eerder zo dat het legaliteitsbeginsel tot doel had het overheidsoptreden te normeren en dus te waarborgen dat de praktijk in overeenstemming blijft met de theorie? De Commissie ontkent de strijdigheid van de door haar gesignaleerde rechtspraktijk met het legaliteitsbeginsel en pretendeert daarmee ten onrechte dat aan deze praktijk juridische legitimiteit toekomt ${ }^{43}$.

Het tweede argument van de Commissie voor de invoering van een vereenvoudigde procedure is dat door te onderscheiden tussen procedures voor bekennende en ontkennende verdachten, heide doelmatiger kunnen verlopen. Dit is zowel in het belang van de kwaliteit van de rechtspleging als in het belang van de procesdeelnemers. Veel verdachten stellen prijs op een vlotte behandeling van hun strafzaak omdat $z i j$ willen weten waar zij aan toe zijn $n^{\text {v8 }}$.

Dit argument van de Commissie wekt verwondering. Gezien de constatering dat de strafrechtspraktijk reeds overeenkomstig de voorgestelde regeling functioneert. valt niet in te zien dat de invoering van een vereenvoudigde procedure de doelmatigheid van de strafrechtspleging verder zal verhogen"'. Verder doet dit argument van de Commissie veronderstellen dat de inzet van het geding bij ontkennende verdachten wel zill worden bepaald door de vraag of het feit bewezen is en of feit en dader strafbaar zijn. Gezien de huidige strafrechtspraktijk en de voorstellen over de herziening van het gerechtelijk vooronderzoek en de bescherming van getuigen, verdient

95 Zie ook A.A. Franken, Vocging ad infomandum in strafzaken, Arnhem 1993, p. 214: "Op basis van art. $1 \mathrm{~Sv}$ is de regeling van de wijze waarop strafbare fẹter worden berecht in eerste instantie cen aangelegenheid van de wetgever, hetgeen om meer vraagt dan een cenvoudigweg stilzitten en de rechtsontwikkeling aan de rechter overlaten. Vanuit dat perspecticf kan codificatie van een reeds bestaande praktijk dan ook niet achterwege worden gelaten met het argument dat het in de praktijk toch al zo gaat."

T6 Zie herziene concept wetsvoorstel betreffende de vereenvoudigde procedure in strafzaken, p. 11. Zie ook Het Commissie rapport, In: Rapporten herijking strafvordering (1993), a.w., p. 187.

97 Reeds A.A.G. Peters waarschuwde in zijn beroemde oratic 'Het rechtskarakter van het strafrecht', Deventer 1972 voor de verleiding van deze en andere strategieèn om strijdigheid van rechtspraktijken en rechtsbeginselen te ontkennen in het geval dat staatsbelang en ordehandhaving het parool zijn. Dan verliezen beginselen hun regulerende kracht en het recht zijn autonome werking. Hierin schuilt het precaire karakter van rechtsbeginselen. Zie p. 10.

98 Het herziene concept wetsvoorstel, p. 11 en Commissic rapport (1993), a.w., p. 187 en 188.

99 Zie ook de minderheidsrapporten van Van Veen, Koster en Baauw bij het rapport van de Commissic Moons, In: Rapporten herijking strafvordering 1989-1992 (1993), a.w., p. 1971/m 205, in het bijzonder de p. 197, $199 \mathrm{cn} 204$. Zie ook: N. Jörg, Waarom bekennen?, In: Een afzonderlijke procedure voor de bekennende verdachte?, o.r.v. M. Hildebrandt e.a., Arnhem 1993, p. 87 t/m 92. 
deze voorstelling van zaken de nodige nuancering. De vraag of het feit bewezen is, wordt als gevolg van de verwaarlozing van het onmiddellijkheidsbeginsel ook in het geval van ontkennende verdachten feitelijk vaak al beantwoord tijdens het vooronderzoek. Over het algemeen wordt tijdens het onderzoek ter terechtzitting het gedurende het vooronderzoek verzamelde bewijs immers door de rechter nauwelijks meer opnieuw op zijn kwaliteit en betrouwbaarheid getoetst. De Commissie heeft in haar rapport over de herziening van het gerechtelijk vooronderzoek duidelijk te kennen gegeven dat het zwaartepunt van het bewijsonderzoek niet dient te verschuiven van het gerechtelijk vooronderzoek naar het onderzoek ter terechtzitting. Het hier besproken argument is in dat licht enigszins misleidend omdat het de indruk wekt dat de Commissie daar anders over zou denken ${ }^{100}$.

Het derde argument waarvan de Commissie zich bedient, betreft de omstandigheid dat in het strafproces reeds uiteenlopende procedures kunnen worden onderscheiden: de (economische) politierechter, kinderrechter en kantonrechter. Het onderscheidend criterium is steeds de zwaarte/soort van het delict of de leeftijd van de verdachte. Daarnaast wijst de Commissie op het feit dat ook de transactie kan worden gezien als een soort bijzondere procedure voor 'bekennende' verdachten. Volgens haar kan niet worden ingezien waarom de gedachtengang die hieraan ten grondslag ligt niet kan worden doorgetrokken naar het onderzoek terechtzitting door daar procedureel te onderscheiden tussen be- en ontkennende verdachten.

Tegen dit argument kan worden aangevoerd dat de vereenvoudigde procedure voor bekennende verdachten niet zonder meer op één lijn kan wordien gesteld met de politierechter, de kinderrechter en de kantonrechter, omdat het onderscheid in procedures voor bekennende en ontkennende verdachten dwars door de reeds gemaakte onderscheidingen heen loopt. De voorgestelde vereenvoudigingen hebben namelijk betrekking op de behandeling van het onderzoek ter terechtzitting bij de meervoudige kamer, de politierechter, de kinderrechter en de kantonrechter. Anders gezegd: de voorgestelde procedure heeft in beginsel betrekking op alle verdachten van alle misdrijven en overtredingen. Dit maakt dat uitsluitend aan het argument dat ook de transactie als een soort bijzondere procedure voor 'bekennende' verdachten kan worden aangemerkt, betekenis tockomt. Van dit argument kan echter worden gezegd, dat aan de transactie uit een oogpunt van controle (openbaarheid, scheiding der machten en contradictoire procesvoering) wel degelijk problematische kanten kleven $^{101}$. Dat de transactie wegens een beperkte vervolgingscapaciteit uit onze

100 Zie ook T. Prakken, Naar een tweesporig strafproces (1992), a.w., p. 1298: "Het meest in het oog springende voordeel van een tweesporig strafproces (..), is dat het in principe de mogelijkheid binnen praktisch bereik brengt om belangrijke strafzaken eindelijk weer eens op een behoorlijke manier conform de strekking van het Wetboek van Strafvordering behandeld te krijgen, zonder daarvoor afhankelijk te zijn van de welwillendheid van de officier van Justitic en rechtbank."

101 Zie hierover bijvoorbeeld: G.J.M. Corstens, Deverhouding rechter-openbaar ministerie, Arnhem 1983 , p. 10. 
strafrechtspleging niet meer valt weg te denken, betekent nog niet dat men deze. als uitzondering bedoelde rechtsfiguur dan maar tot regel moet verheffen ${ }^{102}$.

Als vierde argument vóór invoering van een vereenvoudigde procedure noemt de Commissie dat daarmee tevens de mogelijkheid kan worden geopend om ook in hoger beroep met een vereenvoudigde behandeling te volstaan. Aansluitend is ook de behandeling in cassatie beperkt tot de beslissing omtrent de opgelegde straf of maatregel. Voor zover de Commissie hiermee wil aangeven dat de vereenvoudigde procedure ten goede komt aan de effectiviteit van het strafproces, in de zin van een zo kort mogelijk durende procedure, valt dit argument samen met het door haar afzonderlijk genoemde vijfde argument: werkbesparing. Daarvan heeft reeds menig schrijver de houdbaarheid in twijfel getrokken ${ }^{103}$. Met name de verplichting van de rechter om alsnog de normale procedure te volgen wanneer de verdachte ter zitting weigert om opnieuw een bekentenis af te leggen of ondanks andersluidende verklaring toch overgaat tot het voeren van een bewijsverweer, kan ertoe leiden dat een strafzaak per saldo meer tijd en werk kost dan wanneer meteen de normale procedure zou zijn gevolgd. Het Openbaar Ministerie zal immers bij de appointering van zaken rekening gaan houden met de omstandigheid dat een strafzaak voor een vereenvoudigde procedure in aanmerking komt $^{104}$, zodat wanneer bij nader inzien toch de normale procedure gevolgd dient te worden, de zaak zal moeten worden aangehouden.

\subsection{De vereenvoudigde procedure getoetst aan het recht op een 'fair trial'}

Volgens het herziene concept wetsvoorstel is de minister van mening dat de voorgestelde regeling van de vereenvoudigde procedure voldoet aan de eisen die art. 6 EVRM stelt aan een 'fair trial'. De verdachte die ter zitting een bekentenis aflegt en verklaart geen verweer of geen ander verweer te voeren dan een strafmaatverweer, kiest daarmee voor de vereenvoudigde procedure en komt hierdoor niet meer in aanmerking voor de gewone procedure. Hij gaat akkoord met een beperkte voorlezing van de stukken en met een beperkte behandeling van zijn zaak in hoger beroep. Dit afzien van rechten verdraagt zich volgens de minister met de jurisprudentie van het EHRM op grond van art. 6 EVRM. Wel is hiertoe vereist dat de verdachte goed

102 De Commissie wijst er in haar rapport op dat uit verschillende WODC-onderzoeken is gebleken dat in $85.95 \%$ van de onderzochte gevallen de verdachte bekent en een verweer voert dat geen betrekking heeft op het bewijs. Zie Commissie rapport (1993), a.w., p. 186, voctnoot nr. 1.

103 Zie bijvoorbeeld: N. Jörg, Een vereenvoudigde procedure in strafzaken, NJB 1993, p. 202; J. Naeyé, De opsoringsrisico's van een vereenvoudigde procedure voor de bekennende verdachte, In: Een aparte procedure voor de bekennende verdachte, o.r.v. M. Hildebrandt, Arnhem 1993, p. $45 \mathrm{t} / \mathrm{m}$ 57 , in het bijzonder p. 56 en 57 . Zie ook het minderheidsrapport van Th.W. van Veen en dat van F.H. Koster, Rapporten herijking strafvordering 1989-1992 (1993), a.w., p. 197 en 200.

104 Doet het Openbaar Ministerie dat niet, dan is de werkbesparing in ieder geval zinloos, omdat de gewonnen capaciteit niet effecticf kan worden besteed. 
is geïnformeerd en handelt uit vrije wil. Dat betekent dat de verdachte moet worden gewezen op de artikelen betreffende de verkorte procedure en in de gelegenheid moet zijn geweest met zijn raadsman te overleggen alvorens hij ter zitting overgaat tot een bekentenis. De minister is van mening dat de voorgestelde procedure aan deze voorwaarden voldoet ${ }^{105}$.

Afgewacht moet worden of de minister in zijn conclusie niet te voorbarig is. Den Hartog waarschuwt dat het EHRM in zijn jurisprudentie op basis van art. 6 EVRM een slag om de arm houdt ${ }^{106}$ : er kunnen zich omstandigheden voordoen waarin afstand van recht onvoldoende basis biedt om een inbreuk te mogen maken op één van de door art. 6 EVRM beschermde rechtsbelangen. Er bestaan daarover nog veel onduidelijkheden. De Straatsburgse instanties hebben zich namelijk nog niet uitgesproken over alle in art. 6 EVRM genoemde rechten en bovendien niet aangegeven in welke gevallen zich een uitzondering kan voordoen op het uitgangspunt dat op basis van afstand van recht de rechtsbelangen van de verdachte kunnen worden aangetast ${ }^{101}$.

Wat betreft het in art. 6 EVRM neergelegde recht op het (doen) ondervragen van getuigen nog dit. Uit de Cardot zaak kan worden afgeleid dat wanneer de verdachte niet reeds ten overstaan van de nationale rechter te kennen heeft gegeven een hem belastende getuigen te willen (doen) ondervragen, hij over schending van dit recht in Straatsburg niet meer kan klagen. Zoals in Hoofdstuk vier werd betoogd, volgt uit de zaak Cardot niet dat de nationale rechter daarmee is ontslagen van zijn plicht om te waken voor een 'fair trial' (lees: een in beginsel onmiddellijk onderzoek ter terechtzitting). Maar dit doet er niet alan af, dat de vereenvoudigde procedure niet via het recht op het horen van belastende getuigen kan worden getoetst aan een 'fair trial', omdat een verdachte die 'instemt' met een verkorte procedure en inderdaad geen verweer of geen ander verweer voert dan een strafmaatverweer in Straatsburg niet ontvankelijk wordt verklaard.

\subsection{De vereenvoudigde procedure en het onmiddellijkheidsbeginsel}

De zittingsrechter dient aan de hand van processtukken voor de aanvang van de terechtzitting na te gaan welke zaken geschikt zijn voor berechting volgens de vereen-

$105 \mathrm{Zic}$ het herziene concept wetsvoorstel, p. 18.

106 Zie ook de Pfeifer and Plankl zaak, EHRM 25 fcbruari 1992, Series A, vol. 227, § 37: "According to the Court's case-law, the waiver of a right guaranteed by the Convention-insofar as it is pemissible - must be established in an unequivocal manner. Moreover, the Court agrees with the Cornmission that in the case of procedural rights a waiver, in order to be effective for Convention puposes, requires minimum guarantees commensurate to its importance.", en $\$ 39$ : "Thus even supposing that the rights in question can be waived by a defendant, the circumstances surrounding the applicant's decision deprived it of any validity from the point of view of the Convention."

107 Zie J.D. den Hartog, Artikel 6 EVRM: Grenzen aan het streven de straf eerder op de daad te doen volgen, Antwerpen 1992, p. $156 \mathrm{l} / \mathrm{m}$ 178, met name p. 160. 
voudigde procedure. Indien de rechter uit de processtukken heeft kunnen opmaken dat de verdachte het feit bekent en de rechter van mening is dat op basis van de processtukken aan de voorwaarden voor strafoplegging is voldaan, dient hij nadat de officier van justitie de zaak heeft voorgedragen, de verdachte te vragen of hij hetgeen hem ten laste is gelegd, heeft begaan en voornemens is om geen verweer of geen ander verweer dan een strafmaatverweer voor te dragen. Beantwoordt de verdachte deze vragen bevestigend, dan mag de rechter het telastegelegde feit als bewezen beschouwen en wordt het onderzoek ter terechtzitting verder beperkt tot het bepalen van een gepaste straf of maatregel.

Het is duidelijk dat de hier geschetste procedure zich niet verdraagt met het onmiddellijkheidsbeginsel. Het onmiddellijkheidsbeginsel verzet zich tegen het gebruik van gereproduceerd bewijs omdat de reproduktie van bewijs de rechter dwarsboomt bij zijn controle van de kwaliteit en betrouwbaarheid van dat bewijs. In de voorgestelde procedure is het de bedoeling dat de rechter zijn oordeel baseert op de stukken van het vooronderzoek - dat wil zeggen gereproduceerd bewijs - en de bekentenis van de verdachte ter zitting.

Hoewel het erop lijkt dat met de eis dat de verdachte zijn bekentenis ter terechtzitting herhaalt, wordt tegemoet gekomen aan het onmiddellijkheidsbeginsel, moet de waarde daarvan niet worden overschat ${ }^{\text {ias }}$. De controle die de rechter op dit bewijs kan uitoefenen blijft beperkt. De rechter mist immers de aanknopingspunten voor een zelfstandige controle. Ter zitting worden voor het bewijs geen getuigen meer gehoord, zodat de rechter het moet stellen met hetgeen uit de stukken blijkt. Op de betrouwbaarheid en kwaliteit van dit gereproduceerde bewijs kan de rechter geen zelfstandige controle uitoefenen. Maar het lijkt ook niet de bedoeling van de voorgestelde regeling te zijn dat de rechter het gereproduceerde bewijs uit de stukken ter zitting uitgebreid gaat toetsen aan hetgeen bijvoorbeeld de verdachte daarop te zeggen heeft. Wanneer de rechter reeds bij het lezen van de stukken aan de houdbaarheid van een bewezenverklaring twijfelt, dient hij immers de bepalingen van de normale procedure toe te passen (voorgesteld art. $366 \mathrm{c} \mathrm{Sv}$ ). Bovendien zou een dergelijke toetsing van het bewijs door de rechter aan de voorgestelde regeling zijn doel ontnemen ${ }^{\text {105 }}$.

108 Zie ook mijn bijdrage: Bekennende verdachte; De plannen rond de vereenvoudigde procedure in strafzaken, NJB 1993, p. 411 en 412 . Zie anders: A.A. Franken, Vocging ad informandum in strafzaken, Arnhem 1993, p. 211, 221 en 222.

109 In dat licht moest ook de volgende opmerking van mij wordt begrepen: "Onduidelijk is vervolgens ook wat van de rechter verlangd wordt, wanneer wordt voorgesteld dat de rechtbank ter zitting ambtshalve kan bepalen dat de verkorte procedure ondanks bekentenis van de verdachte, niet gevolgd zal worden (..). Mijns inziens zijn er slechts twee mogelijkheden: 6 fe rechter is op grond van zijn eigen verantwoordelijkheid (..) van mening dat steeds de normale procedure gevolgd moel worden omdat hij zich niet klakkeloos wenst neer te leggen bij het gepresenteerde verhaal van de officier van Jusitie, of hij accepteert het verhaal van de officier van Justitie uit de stukken. Immers, afgezien van louter technische vragen rond de bestanddelen van de telastelegging en de aanwezigheid van voldoende ongecontroleerd bewijs voor al deze onderdelen, heeft de rechier 
De strijdigheid van de voorgestelde procedure met het onmiddellijkheidsbeginsel heeft als gevolg hiervan vergaande consequenties voor de autonoom rechterlijke functie die voortvloeit uit de scheiding der machten. In de vereenvoudigde procedure is de rechter niet langer gehouden om in volstrekte onafhankelijkheid een zelfstandig oordeel te geven over de kwaliteit en betrouwbaarheid van het vanwege de officier van justitie aangedragen bewijs. Het uitgangspunt dat de executieve wordt gecontroleerd door een onafhankelijke rechter wordt afhankelijk gemaakt van de procespositiekeuze van de verdachte. Ik ben van mening dat de verdachte een dergelijke 'macht' niet toekomt, omdat zijn concrete belangen in het strafproces geheel verschillend kunnen zijn van de meer abstracte belangen die gediend zijn bij de 'checks and balances' die aan een goed ingericht strafproces ten grondslag liggen ${ }^{110}$.

De strijdigheid van de voorgestelde procedure met het onmiddellijkheidsbeginsel heeft ook gevolgen voor de openbaarheid van het strafproces"'. Ter zitting wordt volstaan met een mededeling van de korte inhoud van de stukken voor zover die voor het bewijs van belang zijn ${ }^{112}$. In de verkorte procedure is het gebrek aan openbaarheid als gevolg van het gemis aan onmiddellijkheid zelfs nog groter dan in de normale procedure, waarin de rechter ten gevolge van de 'de auditu'-rechtspraak in de meeste gevallen ook op basis van gereproduceerd bewijs tot zijn oordeel komt. In de normale procedure vindt er ter zitting nog een evaluatie plaats van het gereproduceerde bewijs uit het vooronderzoek ${ }^{113}$. In de vereenvoudigde procedure is zelfs daarvan geen sprake. De rechter in de vereenvoudigde procedure moet zijn oordeel in feite al hebben gevormd voordat het onderzoek ter terechtzitting aanvangt. Hij

geen argumenten voorhanden waaraan hij zijn beslissing omtrent het al dan niet volgen van de verkorte procedure kan toetsen." Zie mijn bijdrage: Bekennende verdachten (1993), a.w., p. 411 en 412.

110 Zie ook J.F. Nijboer, Het streven naar de materiële waarheid in het strafproces, In: Een afzonderlijke procedure voor de bckennende verdachte?, Arnhem 1993, p. 22.

111 Zie ook mijn bijdrage: "De overtuiging van de rechter op basis van de stukken uit het vooronderzock; waarom moeilijk doen als ook de verdachte vindt dat het makkelijk kan?, In: Een afzonderlijke procedure voor bekennende verdachte?, o.r.v. M. Hildebrandt, Arnhem 1993, p. $651 / \mathrm{m} 70$

112 Hier zij nogmaals opgemerkt dat de eveneens op de vereenvoudigde procedure van toepassing zijnde voorgestelde regeling inzake het verkorte proces-verbaal en het verkorte vonnis buiten beschouwing zijn gebleven. Voor de mate van openbaarheid van het strafproces zijn deze plannen zo mogelijk nog ingrijpender dan het gebrek aan onmiddellijkheid. Zie ook noot 78.

113 Daarbij dienen echter de woorden van Nijboer niet vergeten te worden: "Daar in de rechtspleging sinds 1926 via de auditu-constructies het onderzoek ter zitting veelal slechts in hoofdzaak het bespreken van het in het vooronderzoek verzamelde materiaal inhoudt, waaronder verklaringen van verdachten en getuigen, in de vorm waarin ze toen zijn vastgesteld in dat proces-verbaal, leidt deze praktijk methodologisch gezien tot een merkwaardig resultaat: de hypothese wordt naderhand geverifieerd met behulp van dezelfde gegevens - in dezclfde vorm gepresenteerd - als waarmec hij is opgesteld. Wanneer er geen nicuwe gegevens worden gebruikt in het eindonderzoek, zou men kunnen zeggen dat het neerkomt op een min of meer formele herhaling van het eerder onderzochte en de daarop gebaseerde hypothese." Zic J.F. Nijboer, Strafrechtelijk bewijs in de jaren 90: meer dan een papieren werkelijkheid?, D\&D 1990, p. 146 en 147. 
moet immers weten of de zaak voor de vereenvoudigde procedure in aanmerking komt. Het bevestigende antwoord van de verdachte op de vraag of hij hetgeen hem ten laste is gelegd heeft begaan en of hij voornemens is geen verweer of ander verweer dan een strafmaatverweer te voeren, vormt in die zin dan ook geen noodzakelijk bewijsmiddel, maar een vorm van goedkeuring achteraf voor de door de rechter gevolgde werkwijze.

\subsection{Conclusie}

Het voorstel tot invoering van een vereenvoudige procedure voor bekennende verdachte is wederom een voorstel tot verdere aantasting van het onmiddelijkheidsbeginsel. De rechterlijke controle op de kwaliteit en betrouwbaarheid van het bewijs en de daarachter schuilgaande toetsing van het optreden van de overheid door de onafhankelijke rechterlijke macht ${ }^{i 4}$ wordt - weliswaar niet formeel maar dan toch wel materieel - afhankelijk gemaakt van de procespositiekeuze van de verdachte. Ook de mate van openbaarheid van het onderzoek ter terechtzitting wordt op die manier in handen gelegd van de verdachte.

\section{Samenvatting en conclusie}

In dit hoofdstuk werd aan de hand van een drietal plannen om te komen tot een partiële herziening van het Wetboek van Strafvordering onderzocht hoe onze huidige wetgever denkt over het belang van het onmiddellijkheidsbeginsel voor een goed ingericht onderzoek ter terechtzitting. Die (deels gerealiseerde) plannen betroffen de herziening van het gerechtelijk vooronderzoek, de vergroting van bescherming van bedreigde getuigen en de creatie van een vereenvoudigde procedure voor bekennende verdachten.

Uit het wetsvoorstel tot herziening van het gerechtelijk vooronderzoek blijkt dat de minister van mening is dat het zwaartepunt van het bewijsonderzoek dat ten gevolge van de 'de auditu'-rechtspraak is komen te liggen bij het gerechtelijk vooronderzoek, niet moet worden verplaatst naar het onderzoek ter terechtzitting. Het horen van getuigen ter zitting dient zoveel mogelijk te worden voorkomen. De rechtercommissaris wordt de centrale figuur in het strafproces. Hij hoort de getuigen, toetst hun betrouwbaarheid en bepaalt of de verdediging al dan niet bij dit verhoor moet worden toegelaten, alles met de bedoeling de zittingsrechter zoveel mogelijk werk uit handen te nemen. Hoewel door het gebrek aan onmiddellijkheid de controle van het bewijs door de rechter ter terechtzitting achterwege blijft, wordt de hybridische positie van de rechter-commissaris in het gerechtelijk vooronderzoek kennelijk

114 Zie ook J.M. Reijntjes, Strafrechtelijk bewijs in wet en praktijk, Arnhem 1980, p. 6 en 7. 
niet problematisch geacht. Dit is op zijn minst opvallend tegen de achtergrond van de wetenschap dat in Duitsland het gerechtelijk vooronderzoek werd afgeschaft onder meer om de reden dat het instituut van de rechter-commissaris - met de status van rechter maar met de functie van een opsporingsambtenaar - zich niet goed verdraagt met de ideeën over de scheiding der machten, terwijl het Duitse onderzoek ter terechtzitting wel gekenmerkt werd (en wordt) door een sterke werking van het onmiddellijkheidsbeginsel. In tegenstelling tot de situatie in Duitsland lijken in Nederland vooral de praktische argumenten gewicht in de schaal te leggen. Het belang van het onmiddellijkheidsbeginsel moet het afleggen tegen het belang van een zo kort mogelijk durende behandeling van het onderzoek ter terechtzitting.

Uit de Wet Getuigenbescherming blijkt dat de wetgever het onmiddellijkheidsbeginsel opoffert ter bescherming van bedreigde getuigen. Het probleem dat getuigen steeds minder bereid zijn om ter zitting te verschijnen om daar een belastende verklaring af te leggen en het gebrek aan machtsmiddelen om deze burgerplicht af te dwingen wordt bestreden door onder omstandigheden die burgerplicht op te heffen en aan getuigen anonimiteit te verlenen. Dit gaat zo zeer ten koste van het contradictoire element van het proces, dat ernstig moet worden betwijfeld of de wet getuigenbescherming in overeenstemming is met art. 6 EVRM. Een probleem is verder dat de omstandigheden wataronder iemand kan worden aangemerkt als een bedreigde getuige uiteindelijk dreigen te worden bepaald door de getuige zelf, zodat het gevaar bestaat dat de wet een grotere inbreuk op het onmiddellijkheidsbeginsel zal betekenen dan oorspronkelijk de bedoeling was.

Uit het herziene concept wetsvoorstel betreffende de vereenvoudigde procedure voor bekennende verdachte tenslotte blijkt ook weer dat met het oog op werk- en tijusbesparing wordt gekozen voor een nieuwe procedure waarin voor het onmiddellijkheidsbeginsel geen plaats is. De bekennende verdachte mag kiezen tussen de verkorte dan wel de normale procedure en krijgt daarmee de beschikking over de mate van controle die door de rechter wordt uitgeoefend op het optreden van politie en justitie en de mate van openbaarheid van het onderzoek ter terechtzitting. Wanneer bedacht wordt dat in de grote meerderheid van strafzaken de verdachte brekent, dan moet worden afgevraagd of een dergelijke concessie aan het machtsevenwicht van de strafrechtspleging ten bate van een hoogst onzekere werk- en tijdsbesparing, wel verantwoord is.

De conclusie wairtoe de analyse van de weergegeven plannen tot partiële herziening van het Wetboek van Strafvordering leidt, kan verder kort zijn. Het staat er met het onmiddellijkheidsbeginsel in het Nederlandse strafproces niet best voor; nu naast de rechter ook onze wetgever niet erg veel waarde hecht aan de waarborgen die voortvioeien uit het onmiddellijkheidsbeginsel voor een goed ingericht onderzoek ter terechtzitting. Deze constatering is zorgwekkend omdat verwaarlozing van het onmiddellijkheidsbeginsel gevolgen heeft voor de gehele structuur van het strafproces en ten koste gaat van de kwaliteit van de strafrechtspleging. Wanneer openbaarheid, scheiding der machten en contradictoire procesbehandeling, kortom onmiddellijkheid voor de wetgever geen serieuze uitgangspunten meer vormt, zijn de grenzen zoek 
en wordt de deur opengezet voor een steeds verdere ondergraving van het machtsevenwicht dat aan het strafproces ten grondslag ligt. 


\section{Conclusie}

\section{Oorsprong van het onmiddellijkheidsbeginsel}

Het onmiddellijkheidsbeginsel vindt zijn oorsprong in het strafproces van de Code d'Instruction Criminelle. Dit strafproces kenmerkte zich door de openbaarheid en de mondelinge behandeling van het onderzoek ter terechtzitting. Deze uitgangspunten werden na de Franse overheersing als belangrijke voorwaarden voor een deugdelijke strafrechtspleging uit het Franse recht overgenomen en aan onze strafrechtspleging ten grondslag gelegd. Aanvankelijk beschouwd als garanties tegen het geheime en schriftelijke strafproces van weleer, ontpopten deze uitgangspunten zich als de middelen tot een verder gelegen doel: onmiddellijkheid. Via de eis van mondelinge procesvoering werd bewerkstelligd dat getuigen zelf ter zitting verschenen om daar rechtstreeks hun verklaringen af te leggen. Daarmee werd het onderzoek ter terechtzitting openbaar, naar het publiek toe, naar de verdachte toe en naar de rechter toe.

\section{Ratio en betekenis van het onmiddellijkheidsbeginsel}

Het onmiddellijkheidsbeginsel is ontstaan uit het streven naar betere waarheidsvinding. Vanuit de idee dat iedere reproduktie van bewijs een kans op vertekening daarvan met zich brengt, eiste het onmiddellijkheidsbeginsel dat de rechter zijn kennis van de feiten niet langer baseerde op hetgeen door derden mondeling dan wel schriftelijk was overgeleverd. De relatie tussen het bewijs en de rechter diende onmiddellijk: te zijn. Toch moet de ratio van het onmiddellijkheidsbeginsel niet worden gezocht in de grotere betrouwbaarheid van het onmiddellijke bewijs, omdat dan de kans op vertekening van de informatie is teruggebracht tot nul, maar in de betere controleerbaarheid van die informatie. Het meest onmiddellijke bewijs is niet per definitie het meest betrouwbare bewijs. Omdat hetgeen in de verleden tijd is voorgevalien nooit meer met absolute zekerheid kan worden vastgesteld, is de waarheidsvraag in het strafrecht uiteindelijk afhankelijk van de waarde die de rechter aan het voorhanden zijnde bewijs toekent. Het gaat aldus om de optimalisering van de bewijswaardering door de rechter. Wanneer de oorspronkelijke bronnen van het bewijs ter zitting worden gepresenteerd in aanwezigheid van de verdachte, heeft de rechter bij de vaststelling van de betrouwbaarheid en kwaliteit van het hewijs drie voordelen, die 
worden gemist wanneer hij slechts de reproducerende bronnen van dat bewijs onder ogen krijgt. Die voordelen zijn: Ten eerste dat hij de oorspronkelijke bronnen zelf waarneemt. Ten tweede dat hij aan de oorspronkelijke bronnen (zo mogelijk) vragen kan stellen over onduidelijkheden of tegenstrijdigheden. Ten derde dat hij de oorspronkelijke bronnen kan confronteren met elkaar en met de verdachte en zijn verdediging. Reproducerende bronnen beschikken niet over de wetenschap of informatie van de oorspronkelijke bron.

Het onmiddellijkheidsbeginsel is aldus een bewijsbeginsel dat eist dat de oorspronke lijk bronnen van bewijs ter zitting worden gepresenteerd, opdat de rechter alleen dat bewijs aan zijn oordeel ten grondslag legt, dat hij zelfstandig op zijn kwaliteit en betrouwbaarheid heeft kunnen controleren door middel van zijn eigen waarneming, (zo mogelijk) ondervraging en de confrontatie met ander bewijs en/of de verdediging. Maar het onmiddellijkheidsbeginsel is tevens een structuurbeginsel waarvan de naleving consequenties heeft voor de inrichting van het hele strafproces. Immers, een strafproces dat niet of onvoldoende tegemoet komt aan het onmiddellijkheidsbeginsel doet daarmee in dezelfde mate afbreuk aan de openbaarheid, de autonoom rechterlijke functie (scheiding der machten) en het contradictoire karakter van het strafproces. De vormen van controle die achter deze uitgangspunten van ons strafproces schuilgaan, bepalen het kwetsbaar evenwicht van 'checks and balances' waarop de strafrechtspleging rust.

\section{Het onmiddellijkheidsbeginsel in ons strafproces sinds 1926}

De ontwerpers van het Wetboek van Strafvordering 1926 hebben de bedoeling gehad, in navolging van het Wetboek van Strafvordering 1838, het onderzoek ter terechtzitting vooral een openbaar en mondeling karakter te geven. Getuigen dienden in beginsel ter zitting te verschijnen om daar hun verklaringen af te leggen. Alleen de getuigenverklaring van de (opsporings)ambtenaar werd in schriftelijke vorm voor het bewijs toegestaan. De schriftelijke verklaring van horen zeggen was voor het bewijs uitgesloten. Over de toelaatbararheid van de mondelinge verklaring van horen zeggen dalarentegen heeft de wetgever geen duidelijkheid kunnen verschaffen. In het licht van het doel van een openbaar en mondeling onderzoek ter terechtzitting is deze tekortkoming invoelbaar.

Geconfronteerd met de vraag naar de toelaatbaarheid van de verklaring van horen zeggen, besloot de Hoge Ralad onder leiding van Taverne de kwestie te beslissen ain de hand van de grammaticale interpretatie van art. 342 lid 1 Sv. Taverne was voor toelating van de verklaring van horen zeggen voor het bewijs omdat een verbod daartoe in de praktijk zinloos is; de rechter is niet in staat uit te sluiten hetgeen hij toch al weet. Achter deze mening van Taverne gaat echter een taakopvatting van de rechter schuil die niet strookt met de achterliggende structuur van het strafproces waarbij het onderzoek ter terechtzitting fungeert ter legitimatie van het overheidsoptreden. 
In het 'De auditu'-arrest oordeelde de cassatierechter dat hetgeen iemand hoort van een ander een zuivere gehoorsindruk vormt, die 'zelf wordt waargenomen of ondervonden'. De mondelinge verklaring van horen zeggen is daarmee niet in strijd met de wet. Met deze interpretatie introduceerde de Hoge Raad via de schriftelijk getuigenverklaring van de opsporingsambtenaar tegen de bedoeling van de wetgever ook de schriftelijke verklaring van horen zeggen. Van het mondelinge en openbare karakter van het onderzoek ter terechtzitting is dientengevolge niet veel terechtgekomen, te meer niet doordat de Hoge Raad ook het gebruik van de anonieme getuigenverklaring accepteerde.

\section{De relatie tussen het onmiddellijkheidsbeginsel en een 'fair trial'}

Het onmiddellijkheidsbeginsel ligt ten grondslag aan het recht van iedere verdachte op een 'fair trial', met deze aantekening dat niet elke relativering van het onmiddellijkheidsbeginsel schending van een 'fair trial' betekent.

Een 'fair trial' veronderstelt in beginsel dat alle bewijs ter zitting ten overstaan van de rechter en in aanwezigheid van de verdachte wordt geproduceerd. Op deze regel bestaan uitzonderingen die rechtvaardiging behoeven. Die rechtvaardiging kan worden gevonden in de onmogelijkheid om het bewijs ter zitting te produceren, bijvoorbeeld omdat een getuige onvindbaar is of gebruik wenst te maken van zijn of haar verschoningsrecht. Bovendien dienen in dergelijke uitzonderingssituaties de rechten van de verdediging in voldoende mate te zijn gerespecteerd. Dit betekent dat de verdachte gedurende enige fase van de procedure een passende en adequate gelegenheid moet hebben gehad om de hem belastende getuige te (doen) ondervragen. Daartoe dient de verdediging op de hoogte te zijn van de identiteit van de getuige. Onder omstandigheden is de bekendheid met een aangenomen identiteit van de getuige voldoende. Aanwezigheid van een raadsman is hiervoor geen absoluut vereiste. Heeft de verdachte geen passende en adequate gelegenheid gehad de hem belastende getuige te (doen) ondervragen dan mag de betreffende gereproduceerde getuigenverklaring toch voor het bewijs meewerken zonder dat dit een schending van een 'fair trial' oplevert, mits dit bewijs bevestigd wordt door ander bewijs en niet het enige bewijs vormt dat voorhanden is.

Het feit dat het EHRM aangeeft dat de verantwoordelijkheid voor naleving van de minimumeisen die het EVRM stelt aan een eerlijke behandeling van een ieders strafzaak primair een nationale aangelegenheid is, betekent niet dat alleen de verdachte en zijn raadsman er alert op dienen te zijn dat zij krijgen wat hen toekomt. De rechter behoudt zijn eigen verantwoordelijkheid voor de 'fairness' van de procedure.

Helaas heeft de invloed van Europese jurisprudentie tot op heden niet kunnen bewerkstelligen dat het onderzoek ter terechtzitting in het Nederlandse strafproces zijn schriftelijke en geheime karakter heeft moeten prijsgeven. De oorzaak hiervan is gelegen in de, ten opzichte van de in Nederland gebnuikelijke wijze van behandeling 
van strafzaken, welwillende interpretatie van deze jurisprudentie door de Hoge Raad. Wanneer de verdediging nalaat een gemotiveerd verzoek te doen om een getuige ter zitting te kunnen ondervragen, dan behoeft de rechter daartoe niet ambtshalve over te gaan. Heeft de verdachte gedurende het vooronderzoek de gelegenheid gehad de hem belastende getuige te (doen) ondervragen dan behoeft een verzoek tot het horen van deze getuige ter zitting niet gehonoreerd te worden, wil zijn verklaring uit het vooronderzoek door de rechter voor het bewijs worden gebruikt. Daarnaast behoeft de verdachte niet het recht te worden geboden de hem belastende getuige te kunnen ondervragen, indien de bewezenverklaring voldoende steun vindt in ander bewijs. Ook het gebruik van anonieme getuigenverklaringen is in de ogen van de Hoge Raad onder omstandigheden niet in strijd met de Europese jurisprudentie, omdat de belemmeringen van het ondervragingsrecht van de verdachte door het optreden van de rechter-commissaris kunnen worden gecompenseerd.

5 De opvatting van de huidige wetgever over het belang van het onmiddellijkheidsbeginsel voor een deugdelijke stralrechtspleging en de waardering daarvan

Gezien de plannen tot partiële herziening van het Wetboek van Strafvordering heeft onze huidige wetgever geen hoge dunk van het belang van het onmiddellijkheidsbeginsel voor een deugdelijke strafrechtspleging. Sinds het 'De auditu'-arrest kent het onmiddellijkheidsbeginsel een moeilijk bestaan in het Nederlandse strafproces. Dat hestaan zal er in de toekomst niet makkelijker op worden. De plannen van de wetgever beogen de wet in overeenstemming te brengen met de bestaande praktijk en op onderdelen zelfs een grotere relativering van het onmiddellijkheidsheginsel te hewerkstelligen dan reeds voor het Nederlandse strafproces kenmerkend is. Deze relativeringen worden verdedigd met een beroep op de omvang en aard van de hedendaagse criminaliteit. Het gevaar is echter dat het middel erger blijkt te zijn dan de kwaal. In een iets ander verband schreef Schalken onlangs:

"Het rechtsstaatgehalte van de strafrechtspleging staat onder druk omdat het doel belangrijker is dan de waarden die worden vertegenwoordigd. Het curieuze is dat hierdoor een tegengesteld effect wordt opgeroepen. De toenemende commercialisering van politie en justitie makt de overheid extra vatbaar voor de corrumperende invloeden die zij in de georganiseerde criminaliteit wil bestrijden. Door aan te vallen verzwakt zij haar eigen verdediging. (..) Bij de bestrijding van misdaadorganisaties is het zaak dat de overheid trouw blijft aan zich zelf, onvatbaar voor corruptie, onkreukbaar in haar idealen. Dat moet ertoe leiden dat zij de aanval niet te ver van huis zoekt, maar de verdediging vanuit het eigen bastion opbouwt. Want het beste wapen van de overheid tegen de onverzadigbare belangen van de georganiseerde misdaad is de integriteit. In het debat over de moraliteit van de 
samenleving ligt daar de voorbeeldfunctie van de overheid. Integriteit is geen normatieve luxe, maar een voorwaarde om te overleven. Soms is verdediging de beste aanval."

Hoewel ik het in dit proefschrift niet expliciet heb gehad over corruptie bij de politie en dit citaat om die reden misschien vergezocht lijkt, denk ik dat het hier toch niet misplaatst is. Het geeft weer dat de overheid belang heeft bij een krachtige controle van politie en openbaar ministerie door een onafhankelijke strafrechter. Dat de overheid baat heeft bij een sterke verdediging van belangen van strafrechtelijk vervolgden ${ }^{2}$. En dat de overheid gediend wordt door de openbaarheid van haar strafrechtspleging. Want uiteindelijk gaat het om de legitimatieverwerving voor het overheidsoptreden dat door middel van de strafrechtelijke procedure wordt nagestreefd. Dat is de reden waarom bij de inrichting van het strafproces de oriëntatie op het onmiddellijkheidsbeginsel als noodzakelijke voorwaarde voor de openbaarheid, de autonoom rechterlijke functie en het contradictoire karakter daarvan, zo belangrijk is. Immers, door die openbaarheid, de contradictoire procesvoering en rechterlijke onafhankelijkheid krijgt de democratie extra gestalte omdat de afstand tussen burger en overheid wordt verkleind doordat de wet kan worden getoetst aan de onderliggende norm en aan concurrerende belangen'. De wet die, en het daarop gebaseerde overheidsoptreden dat, deze toets kan doorstaan wint daarmee aan gezag. Dat gezag is mijns inziens noodzakelijk, omdat op de lange duur alleen dat de basis vormt voor normconform handelen.

Tot slot nog dit. Aan het onmiddellijkheidsbeginsel komt geen absolute gelding toe, dat is zonder meer waar. Daar is het ook een beginsel voor. Maar als uitgangspunt voor een deugdelijke inrichting van ons strafproces is het, zoals gezegd, onontbeerlijk. Daarom moet een onmiddellijk onderzoek ter terechtzitting regel blijven en de uitzondering daarop als zodanig worden erkend. Voor het antwoord op de vraag waar het beginsel der onmiddellijkheid zijn grenzen vindt, biedt mijns inziens

1 Zic Tom Schalken, Moderne misdaadhestrijding, Volkskrant van 4 januari 1994.

2 Zie Th. A. de Roos, Verdediging van belangen: het belang van de verdediging, Arnhem 1991, p. 6: "(.) Men kan uit dit voorbecld dus leren, dat er een bepaalde positieve relatie bestaat tussen de verdediging van de belangen van strafrechtelijk vervolgden in een tegen hen aangespannen procedure, en de bevordering van het belang van de gevestigde macht dic uit is op instemming en onderstcuning door de (nationale en internationale) gemeenschap."

3 Zic in dit verband ook A.A.G. Peters, Het rechtskarakter van het strafrecht, Deventer 1972, p. 19: "Het toetsen van de wet aan de onderliggende norm en aan concurrerende bclangen lcidt tot cen legitimatie van het zich in de stralrechtspleging manilesterende gezag, die rijkcr aan inhoud is, en meer beantwoordt aan het idcaal van behoorlijke procedure, dan een legitimatie welke volktant met terug te verwijzen naar de wil van de wetgever of die, zoals in het geciteerde vers van Auden, afhankelijk is van het traditionele gezag van de rechter. Het is een vorm van legitimeren waarin motivering van daden van gezag, en van interpretaties in deze of gene richting van de wet, niet wordt geschuwd, maar waarin beweringen van feiten en recht worden onderworpen aan een regiem van kritische, op tegenspraak ingestclde discussic." 
de Straatsburgse jurisprudentie, zoals geanalyseerd in dit proefschrift, goede aanknopingspunten. 


\section{Conclusion}

\section{The origins of the principle of immediacy}

The principle of immediacy finds its origins in the penal procedure laid down in the Code d'Instruction Criminelle. A predominant feature of this procedure was the public and oral character of the investigation at trial. After the occupation of the Netherlands by the French in 1811 , these starting points were adopted by the Dutch criminal law from French law, because they were seen as important conditions for a proper administration of criminal justice. Originally considered as safeguards against the secret and written criminal proceedings that existed at the time, these points of departure manifested themselves as a means to another end, namely the prohibition against derivative evidence. The requirement for oral proceedings ensured that witnesses appeared before the judge in person to give testimony. And thus criminal proceedings lost their secret character for the public. the defendant and the judge.

\section{Ratio behind and meaning of the principle of immediacy}

The principle of immediacy is the result of an effort to improve fact finding. Based on the idea that any reproduction of evidence bears the risk of distortion, the principle of immediacy required that the judge no longer based his knowledge of the facts on what was conveyed, either by word of mouth or in written form, by secondary sources of information. There was to be a direct link between the evidence and the judge. Nevertheless, the ratio behind the principle of immediacy cannot be found in the greater reliability of immediate evidence, -the risk of distortion being reduced to zero-, but in an enhanced possibility of verifying information, since the most immediate evidence is not necessarily the most reliable. Inasmuch as what happened in the past can never be established with absolute certainty, the question of fact ('the truth') in criminal law is ultimately contingent on the weight the judge attaches to the evidence before him. The issue, therefore, is to optimize the judge's appreciation of evidence. In establishing the reliability and quality of the evidence, the production of the primary sources of evidence in court in the presence of the defendant has advantages over presenting the judge with evidence which is reproduced. The first advantage is that the judge takes cognizance of the original 
sources. The second is that he may examine primary sources in case of ambiguities or conflicting matters. And thirdly, he is able to confront the primary sources with each other and with the defense, i.e. the defendant and his/her counsel. Derivative sources of evidence do not contain the knowledge or information that is contained in the original source.

The principle of immediacy is therefore an evidential principle necessitating that the primary sources of evidence be produced in court, so that the judge will base his judgement solely on evidence he was able to examine independently as to its quality and reliability through his own observation, examination and confrontation with other evidence and/or the defense. However, the principle of immediacy is also a structural principle. Compliance with this principle has consequences for the systematic organization of criminal procedure itself; if in criminal procedure either no room or insufficient room is allowed for the principle of immediacy, this constitutes to a similar degree a violation of the principle of public hearings, the autonomy of the judiciary (separation of powers) and the contradictory character of criminal proceedings. The forms of control underlying these principles of Dutch criminal procedure determine the delicate system of 'checks and balances' that lies at the root of the Dutch criminal justice system.

\section{The principle of immediacy in Dutch criminal procedure since 1926}

The framers of the 1926 Dutch Code of Criminal Procedure (CCP) had the special intention of making the investigation at trial an open court procedure, as under the 1838 Code of Criminal Procedure. In principle, witnesses had to appear in court to give their testimony. The only written form of evidence that was permitted was testimony by investigating officers. Written hearsay evidence was excluded as a means of evidence. However, the legislator was not conclusive about the admissibility of oral hearsay evidence. This shortcoming must be appreciated in the light the public and oral character of the investigation at trial.

Confronted with the question whether oral hearsay was admissible, in 1927 the Netherlands Supreme Court, inspired by Justice Taverne, ruled that a grammatical interpretation of articles 342 , section 1 CCP should decide the issue. Taverne favoured admission of oral hearsay, because its prohibition was of no practical effect; judges are unable to exclude what they already know. Taverne's view, however, represents a sense of judicial duty that does not accord with the underlying system of criminal procedure, in which the investigation at trial serves to legitimize the acts of the administration. In their 'de auditu' judgment, the Netherlands Supreme Court held that what a person hears from another person is a mere aural impression, that is 'perceived or experienced' by him/her. On the basis of this interpretation, oral hearsay is not contrary to the law. Against the intention of the legislator, the Supreme Court thus introduced the written hearsay statement via the written testimony of investigating officers. As a result, not much has come of the oral and public character of the 
investigation at trial, even more so because the Supreme Court also has allowed evidence by anonymous witnesses.

\section{The relation between the principle of immediacy and the right to a 'fair trial'}

The principle of immediacy lies at the root of the right of every defendant to a fair trial. However, not every restriction of the principle of immediacy constitutes a violation of the right to a fair trial.

In principle, 'fair trial' presupposes that all evidence is produced in court before the judge in the presence of the defendant. There are exceptions to this rule, but these require justification, which may be found in the impossibility of producing evidence in court, for instance, because a witness cannot be traced or wishes to invoke witness' privilege. Furthermore, there must be due respect for the rights of the defense in those exceptional cases. This means that, at some stage of the proceedings, the defense must be given proper and adequate opportunity to question witnesses against them. For this purpose, the defense must be informed of the identity of the witness. In some cases, having been informed of the assumed identity of the witness will suffice. The presence of counsel at the confrontation is not absolutely required. Even if the defendant was not given proper and adequate opportunity to question a witness against him/her, the relevant reproduced evidence may be validly considered in establishing proof. Providing the evidence is corroborated by another source of evidence and does not form the only proof available, this does not constitute a violation of the right to a fair trial.

The fact that the European Court of Human Rights stipulates that the responsibility for adhering to the minimum requirements under the ECHR for a fair disposition of criminal cases is a national matter, not only calls for alertness on the part of the defendant and his/her counsel to ensure that they receive the treatment they are entitled to; the judge also remains responsible for ensuring that proceedings are conducted fairly.

Unfortunately, hitherto the influence of European case law has not caused Dutch criminal proceedings to give up their written and secret character. This can be explained by the Netherlands Supreme Court's interpretation of European case law, which is charitable with regard to the current practice in the Netherlands. If the defense omits to make a reasoned application to examine a witness in court, the judge is not obliged to examine that witness of his own volition. If the defense had the opportunity to question the witness during the preliminary stage of the investigation, the request to hear this witness in court does not need to be honoured for the statement the witness made during the preliminary investigation to be used in evidence. Moreover, the defendant need not be given the opportunity to challenge the witness against him/her in case the establishment of proof is sufficiently corroborated by other evidence. Equally, the Netherlands Supreme Court does not regard the use of anonymous witnesses as being in violation of European case law, 
because the restrictions of the defendant's right to examine a witness may be counterbalanced by the procedure followed by the examining magistrate in the preliminary stage of the criminal investigation.

\section{The present legislator's view on the importance of the principle of immediacy for a proper administration of criminal justice and the author's assessment of this view}

Judging from the plans for a partial review of the Dutch Code of Criminal Procedure, the author concludes that the present Dutch legislator fails to appreciate the importance of the principle of immediacy for a proper administration of criminal justice. Since the Supreme Court's 'de auditu' judgment, the position of the principle of immediacy has become precarious in Dutch criminal procedure and is not likely to improve. The legislator aims at adapting the law to the existing practice, and, in some respects, to weaken the principle of immediacy even beyond what is now current in Dutch criminal procedure. This weakening is being defended by pointing at the extent and nature of criminality today. There is a danger, however, that the cure will be worse than the disease. In a somewhat different context, Schalken recently wrote:

"The legitimacy of the criminal justice system has come under pressure, because the aim is more important than the values it represents. The curious point here is that this creates the opposite effect to what had been intended. As a result of an increasing commercialization of the police force and the criminal justice department, the authorities have become especially vulnerable to precisely the corrupting influence of organized crime they try to curb. By their attack they weaken their defense. (..) In fighting criminal organizations it is essential that the authorities remain loyal to themselves, incorruptible, and unyielding in their ideals. In consequence, they should organize their defense from within their own bastion and not attempt to carry out an attack on the battleground. The best weapon against the insatiable interests of organized crime is administrative integrity. This is the example the authorities should set for the debate on society's moral values. Integrity is no normative luxury, but a condition for survival. Sometimes, defense is the best attack."'

Although the author has not explicitly dealt with police corruption in her dissertation, and the quotation might therefore seem somewhat far-fetched, it is to the point. It states, in so many words, that the authorities have a stake in a vigorous control of the police and the criminal justice department by independent criminal courts; that the authorities benefit from a strong defense of the interests of those under

1 Seč Tom Schalken, Moderne misdaadbestrijding, Volkskranl 4 January 1994. 
criminal prosecution; ${ }^{2}$ and that the public character of criminal proceedings is to the administration's advantage, since, ultimately, public administrators want their acts to be legitimized by these proceedings. This is the reason why, when organizing a system of criminal procedure, it is important to focus on the principle of immediacy as a necessary prior condition for public criminal proceedings, the autonomy of the judiciary and the contradictory character of criminal proceedings. This open court procedure, contradictory proceedings and an independent judiciary give democracy a clearer profile, because the distance between citizens and the administration is reduced by the fact that the law can be tested against the underlying legal norm and against competing interests. ${ }^{3}$ The law and the administrative action based on it that pass this test, gain in authority. Such authority, the author argues, is necessary, because, in the end, it forms the only basis for citizens to act in conformity with the law.

And lastly this. It is conceded that the principle of immediacy has no absolute validity. It is, after all, a principle. But as a basic starting point for a proper and appropriate organization of Dutch criminal procedure it is, as was said before, indispensable. That is why examination of primary sources of evidence at trial should continue to be the rule and exceptions to this rule should be just that. In the author's view, the limits to the principle of immediacy can be found in the case law of the Strasbourg Court as analyzed in this dissertation.

Translated by Louise Rayar

2 Sce Th. A. de Roos, Verdediging van belangen: het belang van de verdediging, Arnhem (1991), p. $6:{ }^{n}[.$.$] This example teaches us that there is a specific positive relationship between defending$ the interests of the accused in proceedings against them and promoting the interests of cstablished powers that are secking the consent and backing of the (national and international) community."

3 See in this context also A.A.G. Peters, Het rechtskarakter van het strafrecht, Deventer (1972), p. 17: "Tcsting the law against the underlying norms and competing interests results in a legitimization of the authority manifested in a criminal justice administration, that is richer in content and does more justice to the ideal of proper procedure than a legitimization that merely refers to the legislator's intent, or one, as in Auden's poem quoted earlier, that is dependent on the traditional authority of the judiciary. $\mathrm{It}$ is a process which does not eschew reasons for acts of authority and for interpretations of the law in one direction or another, but in which statements of facts and law are rather subjected to a regime of critical discussion that is familiar with contradiction." 



\section{Schlußfolgerung}

\section{Der Ursprung des Unmittelbarkeitsprinzips}

Das Unmittelbarkeitsprinzip findet seinen Ursprung im StratprozeB des Code $\mathbf{A}^{\prime} \boldsymbol{n}^{-}$ stnuction Criminc'll', der sich durch eine öffentliche und mündliche Gerichtsw 'rhandlung auszeichnete. Diese Ausgangspunkte wurden nach der Iranzösischen Herrschaft als wichtige Voraussetzungen für eine angemessene Strafrechtspflege aus dem framzösischen Recht übernommen und bildeten die Grundlage des niederländischen Strafprozesses. Anfänglich als Absicherung gegen den geheimen und schriftlichen Strafprozeß früherer Zeiten gedacht, entpuppten sich diese Ausgangspunkte als Wegbereiter für ein weiter entfernt gelegenes Ziel: das Prinzip der Unmittelharkeit. Durch das Erfordernis einer mündlichen Prozeßführung wurde erreicht, daß Zeugen selbst zur Verhandlung erschienen, um dort unmittelbar auszusagen. Damit wurde dic: Beweisaufnahme öffentlich, und zwar öffentlich im Hinblick auf dic Zuhörer, den Beschuldigten und das Gericht.

\section{Ratio und Bedeutung des Unmittelbarkeitsprinzips}

Das Unmittelbarkeitsprinzip ist aus dem Bestreben nach einer besseren Wahrheitsfindung entstanden. Aus dem Gedanken heraus, daß jede Reproduktion von Beweisen die Gefahr der Verzerrung in sich birgt, forderte der Unmittelbarkeitsgrundsatz, daß das Gericht seine Kenntnisse der Sachlage nicht länger auf Aussagen stützte, die von Dritten entweder mündlich oder schriftlich überliefert wurden. Die Beziehung zwischen Beweismittel und Gericht sollte durch Unmittelbarkeit gekennzeichnet sein. Das Motiv für das Unmittelbarkeitsprinzip liegt jedoch nicht in dem Streben nach einer so großen Zuverlässigkeit des unmittelbaren Beweises, daß die Gefahr einer Verzerrung von Informationen völlig ausgeschlossen wäre, vielmehr geht es um die bessere Überprüfbarkeit dieser Informationen. Der unmittelbarste Beweis ist nicht immer auch der zuverlässigste Beweis. Da Geschehnisse aus der Vergangenheit nie mehr mit absoluter Sicherheit nachvollzogen werden können, ist die Frage nach der Wahrheit im Strafrecht letztendlich abhängig von dem Wert, den das Gericht dem erbrachten Beweis zumißt. Es geht hierbei demnach um die Optimalisierung der Beweiswürdigung durch das Gericht. Wenn die ursprünglichen Beweisquellen 
in der Sitzung in Anwesenheit des Beschuldigten präsentiert werden, hat das Gericht bei der Feststellung der Zuverlässigkeit und Qualität des Beweises drei Vorteile, die verlorengehen, wenn es nur reproduzierende Beweisquellen heranziehen kann. Diese Vorteile liegen darin, daß das Gericht die ursprünglichen Quellen selbst wahrnimmt. Zweitens kann das Gericht den ursprünglichen Quellen (wenn möglich) im Falle von Undeutlichkeiten oder Widersprüchen selbst Fragen stellen. Drittens kann das Gericht die ursprünglichen Quellen miteinander sowie mit dem Beschuldigten und seiner Verteidigung konfrontieren. Reproduzierende Quellen verfügen nicht über das Wissen oder die Informationen der ursprünglichen Quellen.

Das Unmittelbarkeitsprinzip ist demnach ein Beweisgrundsatz, der fordert, daß die ursprünglichen Beweisquellen in der Sitzung präsentiert werden, damit das Gericht nur denjenigen Beweis seiner Entscheidung zugrundelegt, den es selbständig auf seine Qualität und Zuverlässigkeit hin durch eigene Wahrnehmung und, wenn möglich, durch die Vernehmung und die Konfrontation mit anderen Beweisen und/oder der Verteidigung hat überprüfen können. Aber das Unmittelbarkeitsprinzip ist gleichzeitig auch ein Strukturprinzip, dessen Berücksichtigung Auswirkungen auf den gesamten Aufbau des Strafprozesses hat. Schließlich beeinträchtigt ein Strafverfahren, das dem Unmittelbarkeitsprinzip nicht oder nur unzureichend entspricht, in gleichem Maße das Öffentlichkeitsprinzip, die unabhängige Rechtsstellung der Richter (Gewaltenteilung) und den kontradiktorischen Charakter des Strafprozesses. Die Formen der Kontrolle, die sich hinter diesen Ausgangspunkten des niederländischen Strafprozesses verbergen, bestimmen das verwundbare Gleichgewicht von checks and balances, auf dem die Strafrechtspflege beruht.

\section{Das Unmittelbarkeitsprinzip in unserem Strafprozeß seit 1926}

Die Begründer der niederländischen Strafprozeßordnung von 1926 (Wetboek van Strafvordering 1926) hatten die Absicht, der Hauptverhandlung nach dem Vorbild des Wetboek van Strafvordering 1838 vor allem einen öffentlichen und mündlichen Charakter zu geben. Zeugen mußten grundsätzlich zur Sitzung erscheinen, um dort ihre Erklärungen abzugeben. Nur die Zeugenaussage des (Ermittlungs-)Beamten wurde in schriftlicher Form als Beweis zugelassen. Das schriftliche Zeugnis vom Hörensagen war als Beweismittel ausgeschlossen. In bezug auf die Zulässigkeit des mündlichen Zeugnisses vom Hörensagen hat der Gesetzgeber dagegen keine Klarheit schaffen können. Im Lichte des Zieles einer öffentlichen und mündlichen Hauptverhandlung ist dieser Mangel nachvollziehbar.

Konfrontiert mit der Frage nach der Zulässigkeit des Zeugnisses vom Hörensagen beschloß der Hoge Raad in 1927 unter dem Vorsitz von Richter Taverne, die Frage anhand der grammatikalischen Auslegung von Artikel 342 Abs. 1 Wetboek van Strafvordering zu entscheiden. Taverne war für die Zulassung des Zeugnisses vom Hörensagen als Beweis, weil ein diesbezügliches Verbot seiner Meinung nach in der Praxis sinnlos sei; der Richter sei nicht in der Lage, Informationen auszuschließen, die er 
ohnehin schon kennen würde. Hinter dieser Haltung von Taverne verbirgt sich jedoch ein Aufgabenverständnis des Richters, das nicht mit der zugrundeliegenden Struktur des Strafprozesses übereinstimmt, bei der die Hauptverhandlung als Legitimation des staatlichen Auftretens fungiert.

In der De auditu-Entscheidung urteilte das Kassationsgericht, daß dasjenige, was jemand von einem anderen hört, einen bloßen Gehöreindruck darstelle, der "selbst wahrgenommen oder erfahren wird". Das mündliche Zeugnis vom Hörensagen widerspreche damit nicht dem Gesetz. Mit dieser Auslegung führte der Hoge Raad über die schriftliche Zeugenerklärung des Ermittlungsbeamten gegen den Willen des Gesetzgebers auch das schriftliche Zeugnis vom Hörensagen ein. Von dem mündlichen und öffentlichen Charakter der Hauptverhandlung ist demnach nicht viel übriggeblieben, zumal der Hoge Raad auch die Verwendung der anonymen Zeugenaussage akzeptierte.

\section{Das Verhältnis von Unmittelbarkeitsprinzip und fair trial}

Das Unmittelbarkeitsprinzip liegt dem Anspruch eines jeden Beschuldigten auf ein gerechtes Verfahren zugrunde, wobei anzumerken ist, daß nicht jede Relativierung des Unmittelbarkeitsprinzips eine Verletzung des fair trial-Prinzips bedeutet.

Ein fair trial unterstellt im Prinzip, daß alle Beweise in der Sitzung gegenüber dem Richter und in Anwesenheit des Beschuldigten vorgebracht werden. Zu dieser Regel gibt es Ausnahmen, die einer Rechtfertigung bedürfen. Diese Rechtfertigung kann z.B. vorliegen, wenn es unmöglich ist, einen Beweis in der Sitzung zu erbringen, etwa weil ein Zeuge unauffindbar ist oder sein Zeugnisverweigerungsrecht in Anspruch nehmen möchte. Außerdem müssen in derartigen Ausnahmesituationen die Rechte der Verteidigung in ausreichendem Maße respektiert werden. Dies bedeutet, $\mathrm{da} ß$ der Beschuldigte während jeder Phase des Verfahrens eine geeignete und adäquate Möglichkeit zur Befragung des ihn belastenden Zeugen haben muß. Dazu muß die Verteidigung die Identität des Zeugen kennen. Unter bestimmten Umstainden ist die Kenntnis einer angenommenen Identität des Zeugen ausreichend. Die Anwesenheit eines Rechtsbeistands ist dafuir nicht absolut notwendig. Hat der Beschuldigte keine geeignete und adäquate Gelegenheit erhalten, den ihn belastenden Zeugen zu befragen oder durch seinen Anwalt befragen zu lassen, darf die so reproduzierte Zeugenaussage dennoch als Beweis herangezogen werden, ohne daß es zur Verletzung des fair trial kommt, sofern dieser Beweis durch andere Beweise bestätigt wird und nicht der einzige vorhandene Beweis ist.

Die Aussage des EuGHMR, die Verantwortlichkeit für die Beachtung der von der EMRK an eine ehrliche Behandlung innerhalb jeder Strafsache gestellten Mindestanforderungen sei primär eine nationale Angelegenheit, bedeutet nicht, da $B$ nur der Beschuldigte und sein Rechtsbeistand darauf achten müssen, daß sie bekommen, was ihnen zusteht. Der Richter behält seine eigene Verantwortlichkeit für die "Fairness" des Verfahrens. 
Leider hat der Einfluß der europäischen Jurisprudenz bislang nicht bewirken können, daß̊ die Beweisaufnahme im niederländischen Strafprozeß $B$ ihren schriftlichen und geheimen Charakter preisgeben mußte. Die Ursache hierfür liegt in der - im Hinblick auf die in den Niederlanden übliche Weise der Behandlung von Strafsachen - wohlwollenden Auslegung dieser Rechtsprechung durch den Hoge Raad. Wenn die Verteidigung es versäumt, einen begründeten Antrag für eine Zeugenvernehmung in der Verhandlung zu stellen, muß das Gericht dazu nicht von Amts wegen übergehen. Hat der Beschuldigte während des Vorverfahrens die Möglichkeit gehabt, den ihn belastenden Zeugen zu befragen oder befragen zu lassen, so muß einem Antrag auf Vernehmung dieses Zeugen in der Verhandlung nicht entsprochen werden, soll seine Erklärung aus der Vorverhandlung von dem Gericht als Beweis benutzt werden. Außerdem braucht dem Beschuldigten nicht das Recht gewährt zu werden den ihn belastenden Zeugen zu befragen wenn die Feststellung des tatsächlichen Sachverhalts ausreichtend durch andere Beweismittel getragen wird. Auch die Verwertung anonymer Zeugenaussagen widerspricht nach Ansicht des Hoge Raad unter bestimmten Umständen nicht der europäischen Rechtsprechung, weil die Einschränkungen des Befragungsrechts des Beschuldigten durch die kommissarische Vernehmung (durch den rechter-commissaris) kompensiert werden können.

\section{Die Auffassung des heutigen Gesetzgebers zur Bedeutung des Unmittelbarkeits- prinzips für eine angemessene Strafrechtspflege und deren Bewertung}

Angesichts der Pläne für eine teilweise Änderung des Wetboek van Strafvordering hat der heutige Gesetzgeber keine hohe Meinung von der Bedeutung des Unmittelbarkeitsprinzips für eine angemessene Strafrechtspflege. Seit der De auditu-Entscheidung hat das Unmittelbarkeitsprinzip im niederländischen Strafprozeß einen schweren Stand, und sein Stellenwert wird sich auch in Zukunft nicht erhöhen. Nach den Plänen des Gesetzgebers soll das Gesetz der bestehenden Praxis angepaßt werden und teilweise sogar zu einer größeren Relativierung des Unmittelbarkeitsprinzips führen als dies ohnehin bereits für den niederländischen Strafprozeß bezeichnend ist. Diese Relativierungen werden mit dem Hinweis auf den Umfang und die Art der heutigen Kriminalität verteidigt. Die Gefahr besteht allerdings, daß hier der Teufel mit dem Beelzebub ausgetrieben wird. In einem etwas anderen Zusammenhang schrieb Schalken unlängst:

"Der Rechtsstaatsgehalt des Strafverfahrens steht unter Druck, weil das Ziel wichtiger ist, als die Werte, die vertreten werden. Eigenartigerweise wird hierdurch das entgegengesetzte Ergebnis erzielt. Die zunehmende Kommerzialisierung von Polizei und Justiz macht den Staat anfïlliger für die korrumpierenden Einflüsse, die er in der organisierten Kriminalität gerade bekümpfen will. Durch seinen Angriff schwächt der Staat seine eigene Verteidigung. (..) Bei der Bekämpfung krimineller Vereinigungen ist es erforderlich, da B der Staat sich selbst treu bleibt, nicht anfällig ist für Korruption und unerschütterlich bleibt in seinen 
Idealen. Dies muß dazu führen, daß er den Angriff nicht in allzu weiter Ferne sucht, sondern die Verteidigung von seinen eigenen Bastionen aus aufbaut. Denn die beste Waffe des Staates gegen die unersättlichen Belange der organisierten Kriminalität ist die Integrität. In der Debatte über die Moralität der Gesellschaft liegt dort die Vorbildfunktion des Staates. Integrität ist kein normativer Luxus, sondern eine Voraussetzung für das Überleben. Und manchmal ist Verteidigung eben der beste Angriff."

Obwohl in dieser Dissertation nicht explizit auf die Korruption bei der Polizei eingegangen wurde und dieses Zitat daher vielleicht etwas weit hergeholt erscheint, zeigt diese Aussage doch, daß der Staat ein gewisses Interesse an einer wirksamen Überwachung von Polizei und Staatsanwaltschaft durch einen unabhängigen Strafrichter hat und Nutzen aus einer starken Verteidigung der Interessen strafrechtlich Verfolgter zieht. ${ }^{2}$ Und auch, daß dem Staat mit der Öffentlichkeit seiner Strafrechtspflege gedient ist. Denn letztlich geht es um die Legitimation für staatliches Auftreten, das durch das Strafverfahren angestrebt wird. Dies ist der Grund dafür, daß bei der Gestaltung des Strafverfahrens die Orientierung am Unmittelbarkeitsprinzip als notwendige Voraussetzung für die Öffentlichkeit des Verfahrens, die unabhängige Rechtsstellung des Richters und den kontradiktorischen Verfahrenscharakter so wichtig ist. Mit der Öffentlichkeit, der kontradiktorischen Prozeßführung und der richterlichen Unabhängigkeit gewinnt die Demokratie an Gestalt, weil der Abstand zwischen Bürger und Staat durch die Überprüfung des Gesetzes anhand der zugrundeliegenden Norm und konkurrierender Interessen verringert wird ${ }^{3}$. Das Gesetz und damit auch das darauf basierende staatliche Auftreten, das diese Prüfung besteht, gewinnt an Macht. Diese Macht ist meiner Ansicht nach notwendig, weil auf lange Sicht nur so dic Grundlage für normkonformes Handeln sichergestellt wird.

Abschließend bleibt festzustellen, daß dem Unmittelbarkeitsprinzip, wie jedem anderen Prinzip auch, keine absolute Geltung zukommt. Doch als Ausgangspunkt für eine angemessene Ausgestaltung unseres Strafverfahrens ist dieser Grundsatz.

1 Siche Tom Schalken, Moderne misdaadbestrijding, Volkskrant, 4. Januar 1994.

2 Siche Th.A. de Roos, Verdediging van belangen: het belang van de verdediging, Arnheim 1991, S. 6: "(..) Mann kann an diesem Beispicl also einc bestimmte positive Bezichung erkennen zwischen der Verteidigung der Interessen strafrechtlich Verfolgter in einem gegen sie angestrengten Verfahren und der Forderung der Interessen der etablierten Ordnung dic aul Zustimmung und die Unterstützung der (nationalen und internationalen) Gemeinschaft aus ist."

3 Siehe in diesem Zusammenhang auch A.A.G. Peters, Het rechtskarakter van het strafrecht, Deventer 1972, S. 19: "Die Überprüfung des Gesetzes anhand der zugrundeliegenden Norm und konkurricrender Interessen führt zu einer Legitimation der sich in der Strafrechtspllege manifestierenden Macht, die reicher an Inhalten ist und mehr dem Ideal eines angemessenen Verfahrens entspricht, als cine Lcgitimation, die sich mit einem Verweis auf den Willen des Gesetzgebers begnügt oder die, wie in dem zitierten Vers von Auden, von der traditionellen Macht des Gerichts abhängig ist. Es handelt sich um eine Form des Legitimierens, bei der die Begründung der Machthandlungen und die Interpretationen in dicse oder jenc Richtung nicht gescheut werden, sondern bei der Bchauptungen von Tatsachen und Recht einem System kritischer, auf Widerrede eingestellter Diskussion unterworfen werden." 
unentbehrlich. Deshalb muß die unmittelbare Beweisaufnahme in der Hauptverhandlung die Regel bleiben und die entsprechende Ausnahme auch als solche erkannt werden. Für die Antwort auf die Frage, wo der Grundsatz der Unmittelbarkeit seine Grenzen findet, bietet meines Erachtens die in dieser Dissertation analysierte Straßburger Rechtsprechung gute Anknüpfungspunkte. 


\section{Lijst van aangehaalde literatuur}

Abrahams, F., Achter gesloten deuren; De wereld van de rechter-commissaris, NRC Handelsblad van 15 januari 1994.

Alkema, A.E., De betekenis van het EVRM voor de Nederlandse Constitutie, In: 40 jaar Europese conventie voor de rechten van de mens en de Nederlandse rechtsorde, L.eiden 1990, p. 3-35.

Alkema, A.E., Annotatie onder EHRM 15 juni 1992, NJ 1993, 711.

Beccaria, C, Over misdaden en straffen, ingeleid, van aantekeningen voorzien en vertaald door J.M. Michiels, tweede uitgave, Antwerpen/Zwolle 1982.

Beyer, A., Kostovski treft anonieme getuige in het hart, Recht en Kritiek 1990, p. 243-258.

Blok, A.J. en L.Ch. Besier, Het Nederlandse strafproces, Haarlem 1925.

Boek, J.L.M. en J.F. Nijboer, Ongehoorde getuigen, Delikt en Delinkwent 1992, p. 1006-1014.

Boek, J.L.M. en J.F. Nijboer, De bekentenis als de koningin van het bewijs, Delikt en Delinkwent 1994, p. 41-58.

Borst, W.L., De bewijsmiddelen in strafzaken, Arnhem 1985.

Bossers, G.F.M., "Welk eene natie, die de jurij gehad heeft, en ze weder afschaft!", Delft 1987.

Bossers, G.F.M. en J.F. Nijboer, De actualiteit van de Carolina, Delikt en Delinkwent 1989, p. $7-18$.

Bromberg, R., Nogmaals "het testimonium de auditu", Nederlands Juristenblad 1928, p. 269-274. 
Bromberg, R., Het "de-auditu-arrest", Nederlands Juristenblad 1928, p. 350-351.

Corstens, G.J.M., De verhouding rechter - openbaar ministerie, Arnhem 1983.

Corstens, G.J.M., Van Cri de justice naar anonieme getuigenverklaring: 75 jaar deauditu-jurisprudentie, In: NJ 1913-1988, Annotatoren kijken terug, Zwolle 1988, p. $34-44$.

Corstens, G.J.M., Getuigen op de zitting, Delikt en Delinkwent 1992, p. 205-211.

Corstens, G.J.M.. Het Nederlandse strafprocesrecht, Arnhem 1993.

Crombag, H.F.M., J.P. van Koppen en W.A. Wagenaar, Dubieuze zaken; De psychologie van strafrechtelijk bewijs, Amsterdam 1992.

Damaška, M., Of hearsay and its Analogues, In: Minnesota Law Revieuw 1992, vol. 76, p. 434-444.

De Bosch Kemper, J., Wetboek van Strafvordering, naar deszelfs beginselen ontwikkeld, en in verband gebragt met de algemeene regtsgeleerdheid, Amsterdam 1838 (eerste deel), 1940 (derde deel).

De Doelder, H. en A.C. 't Hart, Aparte procedure voor bekennende verdachten?, Nederlands Juristenblad 1992, p. 629-6.30.

De Hullu, J., De afstand tot de gemiddelde verdachte; Over het recht ter zitting afstand te doen van rechtsmiddelen en de moderne benadering van 'de verdachte'. In: Een rariteitenkabinet; Opvallende bepalingen in de strafwetgeving, A.A. Franken en A.M. van Woensel (red.), Nijmegen 1993, p. 43-49.

De Jong, D.H., De macht van de telastelegging in het strafproces, Arnhem 1981.

De Monté Verloren, J.P.H. en J.E. Spruit, Hoofdlijnen uit de ontwikkeling der rechterlijke organisatie in de noordelijke Nederlanden tot de Bataafse omwenteling, Deventer 1982 (zesde druk).

De Roos, Th.A., Verdediging van belangen: het belang van de verdediging, Arnhem 1991.

De Roos, Th.A., Naar een contradictoir vooronderzoek?; Mini-instructie op verzoek van de verdachte, Delikt en Delinkwent 1991, p. 599-611. 
De Vries, K., Bijdrage tot de kennis van het strafprocesrecht in de Nederlandse steden benoorden Maas en Schelde; voor de vestiging van het Bourgondisch gezag, Groningen 1955.

Den Hartog, J.D., Artikel 6 EVRM: Grenzen aan het streven de straf eerder op de daad te doen volgen, Antwerpen 1992.

Dijkstra, A. en A.E. Harteveld, De rechter-commissaris in het voorbereidend onderzoek; Voorstel voor een nieuwe plaatsbepaling, In: Liber Amicorum Th. W. van Veen, Arnhem 1985, p. 17-31.

Donker, H.J. en G. Smit, Slachtoffers vrouwenhandel verdienen meer bescherming, Algemeen Politieblad 1990, p. 344-348.

Donker, H.J. en A.C. Maan, Slachtoffers van zware criminaliteit als getuige ter terechtzitting, Nederlands Juristenblad 1991, p. 141-142.

Drenth, J.H., Bijdrage tot de kennis der historische ontwikkeling van het accusatoire tot het inquisitoire strafproces, Amsterdam 1939.

Enschedé, Ch.J., Bewijzen in het strafrecht, Rechterlijk Magazijn Themis 1966, p. $488-518$.

Feith, Rh., De regeling van het bewijs in het ontwerp Wetboek van Strafvordering, Weekblad van het Recht 1914, no. 9666, p. 3-4.

Feith, Rh., Nogmaals "De regeling van het bewijs in het ontwerp Wetboek van Strafvordering", Weekblad van het Recht 1914 , no. 9684 , p. 3-4.

Fijnaut, C.J.C.F., Officier van Justitie versus Bende van de Miljardair, Arnhem 1993.

Fockema Andreae, S.J., Het bewijs in strafzaken hier te lande in de middeleeuwen, Tijdschrift voor Strafrecht 1897, p. 46-88.

Franken, A.A., De inzet van het geding; Een vereenvoudigde procedure in strafzaken voor bekennende verdachten, Delikt en Delinkwent 1993, p. 202-224.

Franken, A.A., Voeging ad informandum in strafzaken, Arnhem 1993.

Frielink, P.M., De anonieme getuige na Kostovski, Delikt en Delinkwent 1990, p. 450-459. 
Garé, D.M.H.R., Het zwaartepunt in het strafproces, In: Schaduwen vooruit; Rechtsgeleerde opstellen over het voorbereidend onderzoek in strafzaken, G.P.M.F. Mols (red.), Arnhem 1992, p. 1-10.

Garé, D.M.H.R., De enkele bekentenis als uitsluitend bewijs in strafzaken, Nederlands Juristenblad 1992, p. 631-633.

Garé, D.M.H.R., Bekennende verdachten; De plannen rond de vereenvoudigde procedure in strafzaken, Nederlands Juristenblad 1993, p. 409-414.

Garé, D.M.H.R., De overtuiging van de rechter op basis van de stukken uit het vooronderzoek; waarom moeilijk doen als ook de verdachte vindt dat het makkelijk kan?, In: Een afzonderlijk procedure voor de bekennende verdachte?, M. Hildebrandt, P.T.C. van Kampen, J.F. Nijboer, H. Wiersinga (red.), Arnhem 1993, p. 65-70.

Geppert, K., Der Grundsatz der Unmittelbarkeit im deutschen Strafverfahren, Berlin 1979.

Gratema, S., Artikelen 331-337, over "Het Bewijs" in het ontworpen Wetboek van Strafvordering, Weekblad van het Recht 1914, no. 9654, p. 7-8.

Gratema, S., Nog eens het bewijs in het ontworpen Wetboek van Strafvordering, Weekblad van het Recht 1914, no. 9675, p. 3-4.

Groenhuijsen, M.S., De herziening van het GVO als onderdeel van de titikverdeling tussen politie, justitie en het rechter-commissariaat, In: Afschaffing of herziening van het gerechtelijk vooronderzoek, C. Fijnaut en E. Kolthofr (red.), Arnhem 1991, p. 25-32.

Haffmans, Ch. en C.F. Rüter, De raadsman op zijn retour, Ars Aequi 1984, p. 625631.

Handelingen der Nederlandsche Juristen-Vereeniging 1882, Den Haag 1882, deel II, p. 143-234.

Handelingen der Nederlandsche Juristen-Vereeniging 1910, Den Haag 1910, deel I, p. 1-95 en deel II, p. 107-220.

Harteveld, A.F., De rechter-commiswaris in strafzaken, Arnhem 1990.

Harteveld, A.E., B.F. Keulen en H.G.M. Krabbe, Het EVRM en het Nederlandse strafprocesrecht, Groningen 1992. 
Hermans, H.L.C., De herziening van het gerechtelijk vooronderzoek: een visie vanuit het rechter-commissariaat, In: Afschaffing of herziening van het gerechtelijk vooronderzoek?, C. Fijnaut en E.Kolthoff (red.), Arnhem 1991, p. 47-58.

Herziening van het gerechtelijk vooronderzoek: een rapport van de Commissie herijking Wetboek van Strafvordering / (voorzitter Ch.M.J.A. Moons), Arnhem 1990.

Jesserun d'Oliveira-Prakken, E., Bewijs als toetssteen van strafrecht, In: Recht, macht en manipulatie, Utrecht 1976, p. 13-46.

Jörg, N. en C. Kelk, Strafrecht met mate, Alphen a/d Rijn 1990) (zevende druk).

Jörg, N., Een vereenvoudigde procedure in strafzaken; Accusatoire tendenties, Nederlands Juristenblad 1993, p. 199-205.

Jörg, N., Waarom bekennen?, In: Fen afzonderlijke procedure voor de bekennende verdachte?, M. Hildebrandt, P.C.T. van Kampen, J.F. Nijhoer, H. Wiersingal (red.), p. $87-92$.

Kirberger, G., Het bewijs in het ontwerp van Strafvordering en de motiveering valn strafvonnissen, Tijdschrift voor Strafrecht 1914, p. 441-452.

Kohlhaas, M., Gedanken zur Reform des Ermittlungsverfahren der StPO, Zeitschrift für Rechtspolitik 1974, p. 7-10.

Langemeijer, F.F., Het onmiddellijkheidsbeginsel in het militaire strafproces, Delikt en Delinkwent 1976, p. 97-100.

Leijten, J.C.M., Overpeinzingen van een andersdenkende, Nederlands Juristenblad 1987, p. 1451-1456.

Leijten, J., De verschrikkelijke eenzaamheid van de inbreker, Nijmegen 1992.

Léon's rechtspraak, literatuur en korte aantekeningen, tweede gedeelte - (art. 258 398), Leiden 1935 (vierde druk).

Löhr, H.E., Der Grundsatz der Unmittelbarkeit im deutschen Strafprozeßrecht, Berlin 1972 .

Maas, S., Der Grundsatz der Unmittelbarkeit in der Reichsstrafprozeßordnung, Breslau 1907. 
Machielse, A.J.M., Een requiem voor het gerechtelijk vooronderzoek, Arnhem 1989.

Manke, K., Die gerichtliche Voruntersuchung in Frankreich, Österreich, Italien und der Schweiz; ein Vergleich im Hinblick auf die Deutsche Strafprozessreform, München 1966.

Meijers, L.C.M., Verdrag en strafproces; Gedachten over een methode van werken, Zwolle 1993.

Meijers, L.C.M. Over Lüdi tegen Zwitserland, EHRM 15 juni 1992, Delikt en Delinkwent 1994, p. $272-277$.

Melai, A.L., Het waarheidsprobleem in het strafproces, In: Handelingen van de vereniging voor Wijsbegeerte des Rechts 1961, Zwolle 1961, p. 43-69.

Melai, A.L., De onbevangen strafrechter, Delikt en Delinkwent 1975, p. 124-127.

Melai, A.L., Het Wethoek van Strafvordering, verklaard en van aantekeningen voorzien (loshladig), M.S. Groenhuijsen, Th.A. de Roos en A.H.J. Swart (red.), Arnhem (z.j.).

Minkenhof, A., De Nederlandse strafvordering, Alphen a/d Rijn, 1981 (vierde herziene druk).

Mittermaier, C.J.A., Die Mündlichkeit, das Anklageprinzip, die Oeffentlichkeit und das Geschworenengericht in ihrer Durchführung in den verschiedenen Gesetzgebungen dargestellt und nach Forderungen des Rechts und der Zweckmäßigkeit mit Rücksicht auf die Erfahrungen der verschiedenen Länder, Stuttgart und Tübingen 1845.

Modderman, W., De wettelijke bewijsleer in strafzaken, Utrecht 1867.

Mols, G.P.M.F., De niet verschenen getuige: enkele gedachten n.a.v. recente jurisprudentie, Advocatenblad 1987, p. 237-241.

Mols, G.P.M.F., Staande de zitting; Een beschouwing over het onmiddellijkheidsbeginsel, Arnhem 1989.

Mols, G.P.M.F., Annotatie Kostovski uitspraak, Advocatenblad 1989, p. 685-690.

Mols, G.P.M.F., Over het onmiddellijkheidsbeginsel in strafzaken, In: Rechtsbeginselen, themanummer van Ars Aequi 1991, p. 160-173. 
Mols, G.P.M.F., Getuigen in het voorbereidend onderzoek in strafzaken, In: Schaduwen vooruit; Rechtsgeleerde opstellen over het voorbereidend onderzoek in strafzaken, G.P.M.F. Mols (red.), Arnhem 1992, p. 47-78.

Mols, G.P.M.F., De zaak Bruinsma, In: Crimineel jaarboek 1992 van de Coornhertliga, Nijmegen 1992, p. 133-135.

Mols, G.P.M.F., Horen, zien en verklaren; Over getuigen en hun verhoor in het Nederlandse strafproces, In: Goed gezien?; Problemen bij identificatiemethoden in strafzaken, H. de Doelder en J. Hielkema (red.), Arnhem 1993, p. 17-32.

Mols, G.P.M.F., Getuigen en strafzaken, Nieuwenhoflezing VI, Deventer 1993.

Mols, G.P.M.F., Politionele bestrijding van georganiseerde criminaliteit; Enkele (kritische) kanttekeningen bij een modern verschijnsel, NJCM-bulletin 1993, p.521533.

Mols, G., Politie lapt wet steeds vaker aan haar laars, NRC Handelsblad van 28 maart 1994.

Monballyu, J., Het onderscheid tussen de civiele en de criminele en de ordinaire en de extraordinaire strafrechtspleging in het Vlaamse recht van de 16e eeuw, In: Misdaad, zoen en straf; aspecten van de middeleeuwse strafrechtsgeschiedenis in de Nederlanden, H.A. Diederiks en H.W. Roodenburg (red.), Hilversum 1991, p. 120-132.

Moorman van Kappen, O., Die Kriminalordonnanzen Philipps II. für die Niederlande im Vergleich zur Carolina, In: Strafrecht, Strafprozess und Rezeption, Frankfurt am Main 1984, p. 227-252.

Mulder, C.F., Het onmiddellijkheidsbeginsel en de structuur van het vooronderzoek in het strafprocesrecht van Denemarken en Noorwegen. Delikt en Delinkwent 1992, p. 1029-1040.

Mulder, C.F. en P.J.P. Tak, De bekennende verdachte; Een onderzoek naar de procedurevoor de bekennende verdachtein het Deense en Noorse (straf-)procesrecht, Monografieën strafrecht deel 17, T.M. Schalken (red.), Arnhem 1993.

Myjer, E., Hoe ver draagt het verdrag?, In: 40 jaar Europese conventie voor de rechten van de mens en de Nederlandse rechtsorde, Leiden 1990, p. 117-126.

Myjer, E., De raadsman en de afwezige verdachte, NJCM-bulletin 1993, p. 811-822. 
Naeyé, J., De opsporingsrisico's van een vereenvoudigde procedure voor de bekennende verdachte, In: Een aparte procedure voor de bekennende verdachte?, M. Hildebrandt, P.T.C. van Kampen, J.F. Nijboer, H. Wiersinga (red.), Arnhem 1993, p. 45-57.

Nederburgh, I.A., Hoofdstukken over strafvordering voor Nederlandsch Indië, deel II: Het Bewijs, Den Haag 1911.

Nijboer, J.F., Enkele opmerkingen over de betekenis van het onmiddellijkheidsbeginsel in het strafprocesrecht, Nederlands Juristenblad 1979, p. 821-824.

Nijboer, J.F., De anonieme informant als getuige in het strafprocesrecht, Recht en Kritiek 1980, p. 411-430.

Nijboer, J.F., Naar een vrije bewijsregeling?, Delikt en Delinkwent 1982, p. 182-192.

Nijboer, J.F., Algemene grondslagen van de bewijsbeslissing in het Nederlandse strafprocesrecht, Arnhem 1982.

Nijboer, J.F., Kanttekeningen bij het rapport 'De bedreigde getuige', Recht en Kritiek, p. 80-93.

Nijboer, J.F., 'B.M. Taverne: onbescheiden magistraat', Delikt en Delinkwent 1985, p. $716-731$.

Nijboer, J.F., Strafrechtelijk bewijs in de jaren '90: meer dan een papieren werkelijkheid?, Delikt en Delinkwent 1940, p. 138-152.

Nijboer, J.F., Kostovski en de inquisitoire stijl van procederen; EHRM 20 november 1989, Nederlands Juristenblad 1990, p. 593-595.

Nijhoer, J.F., Inleiding tot het strafrechtelijk bewijsrecht, Nijmegen 1992 (vierde druk).

Nijboer, J.F., Het streven naar de materiële waarheid in het strafproces, In: Een afzonderlijke procedure voor de bekennende verdachte?, M. Hildebrandt, P.T.C. van Kampen, J.F. Nijboer, H. Wiersinga (red.), Arnhem 1993, p. 11-22.

NJCM-commentaur op het wetsontwerp getuigenbescherming, NJCM-bulletin 1992. p. $8.36-846$.

Peters, A.A.G., Het rechtskarakter van het strafrecht, Deventer 1972. 
Polak, E., De bewijskracht van het proces-verbaal van den opsporingsambtenaar, Tijdschrift voor Strafrecht 1927, p. 151-169.

Pols, M.S., De wettelijke bewijsleer in strafzaken, Rechtelijk Maıalzijn Themis 1882, p. $333-389$.

Pompe, W.P.J., Geschiedenis der Nederlandsche Rechtswetenschap, Deel II, Atlıvering III, Amsterdam 1956.

Prakken, T., Het OM en de anonieme getuige; De zaak Kostovski tegen N., Nederlands Juristenblad 1990, p. 310-312.

Prakken, T., Naar een tweesporig strafproces?, Nederlands Juristenblad 1902, p. 1294-1300.

Rapport van de Werkgroep 'de bedreigde getuige' van de afdeling strafrechtspraak van de Nederlandse Vereniging voor Rechtspralak / (voorzitter S. Slagter), 'Irema Exclusief 7, 1983.

Rapport van de Commissie bedreigde getuigen / (voorzitter: J. Remmelink), Den Hata 1980.

Rapport van de Commissie Herijking Wetboek van Strafvordering tot aanvulling van het Wetboek van Strafvordering met voorzieningen ten behoeve van een vereenvoudigde procedure in strafzaken, november 1992, In: Rapporten herijking strafvordering 1989-1992, G.J.M. Corstens (red.), Arnhem 1993, p. 183-205.

Reijntjes, J.M., Strafrechtelijk bewijs in wet en praktijk, Arnhem 1980.

Rüter, C.F., Ongehoord - Over getuigen en deskundigen ter terechtzitting, In: Ad Personam Ch.J. Enschedé, Zwolle 1981, p. 237-263.

Schalken, T.M., De strafrechter en de anonieme getuige; Enige conflicterende beginselen in het Nederlandse strafproces, In: Beginselen; Opstellen over strafrecht aangeboden aan G.E. Mulder, Arnhem 1981, p. 325-343.

Schalken, T.M., Bedreigde getuige en bedreigde rechtsstaat, Trema 1986, p. 291 $\mathrm{t} / \mathrm{m} 303$.

Schalken, T.M., Strafrecht als systeem van rechtsbetrekkingen; Een ontwikkeling naar evenwicht?, Arnhem 1987. 
Schalken, T.M., Anonieme getuige en strafvorderlijke logistiek, Nederlands Juristenblad 1990, p. 8-13.

Schalken, T.M., Annotatie onder HR 1 oktober 1991, NJ 1992, 197.

Schalken, T.M., Moderne misdaadbestrijding, Volkskrant van 4 januari 1994.

Schild, W., Der 'endliche Rechtstag' als das Theater des Rechts, In: Strafrecht, Strafprozess und Rezeption, Frankfurt am Main 1984, p. 119-144.

Schmidt, E., Fintührung in der Geschichte der deutschen Strafrechtspflege, Göttingen 1965.

Simons, D., Getuigenis van hooren zeggen, Weekblad van het Recht 1927, no. 11604, p. $1-2$.

Simons, D., Beknopte handleiding tot het Wetboek van Strafvordering, Haarlem 1925 (zevende druk).

Spronken, T., Anonieme getuigen: het strafproces op de heling, In: 'Niets dan de waarheid'; Getuigenbewijs in het civiel- en strafrecht, Jonge Balie 1988, Zwolle 1988, p. 25-44.

Stegmaier, H., Die Frage der Unmittelbarkeit bei der Behandlung der Zeugen und Sachverständigen in der Gesetzgebung und im Schriftum des reformierten deutschen Strafprozesses vor der Reichsstrafprozeßordnung, Gießen 1935.

Stolwijk, S.A.M., Het onderzoek ter terechtzitting in strafzaken, Arnhem 1976.

Swart, A.H.J., Minderheidsrapport bij het Rapport van de Commissie Bedreigde Getuigen / (voorzitter: J. Remmelink), Den Haag 1986.

Swart, A.H.J., Rechten van de mens in de strafrechtspleging, Delikt en Delinkwent 1989, p. 554-572.

Swart, A.H.J., Anonieme getuigen, Ars Aequi 1990, p. 315-327.

Tak, P.J.P. en J.A.W. Lensing, Het voorbereidend onderzoek rechtsvergelijkend onderzocht, Arnhem 1990.

Taverne, B.M., Art. 398 van het Wetboek van Strafvordering, Militair Rechtelijk Tijdschrift 1909, p. 105-119. 
Taverne, B.M., Het testimonium de auditu, Tijdschrift voor Strafrecht 1926, p. 115146.

Taverne, B.M., Een nieuw de-auditu-arrest, Nederlands Juristenblad 1928, p. 445-450.

't Hart, A.C., De positie van de Rechter-Commissaris in strafzaken tussen rechtspraak en beleid, In: Strafrecht in balans, Arnhem 1983, p. 81-94.

't Hart, A.C., Inquisitoir of accusatoir; Een maatstaf voor de positie van de bekennende verdachte, In: Een afzonderlijke procedure voor de bekennende verdachte?, M. Hildebrandt, P.T.C. van Kampen, J.F. Nijboer en H.Wiersinga (red.), Arnhem 1993, p. $39-44$.

Traest, P., Het bewijs in strafzaken, (ient 1942.

Undeutsch, U., Vernehmung und non-verbale-Information, In: Wissenschaftliche Kriminalistik, Teilband 1 BKA-Forschungsreihe 16/1, E. Kube, H.U. Störzer und S. Brugger (Hrsgg.). Wiesbaden 1983, p. 389-418.

Van Bavel C.J. en R.P.G.L.M. Verbunt, Slachtoffer/getuige in zedenzaken en verhoor ter zitting, Nederlands Juristenblad 1990, p. 1399-1404.

Van de Laar, J.M., De rechter-commissaris: speler of scheidsrechter in het voorbereidende onderzoek?, Delikt en Delinkwent 1989, p. 379-390.

Van de Pol, U., Openbaar terecht; Een onderzoek van het openbaarheidsbeginsel in de strafrechtspleging, Arnhem 1986.

Van de Pol, U., Schending van vormvoorschriften tijdens het gerechtelijk vooronderzoek, In: In zijn verdediging geschaad; Over vormverzuimen en het belang van de verdachte, T.M. Schalken en E.J. Hofstee (red.), Arnhem 1989, p. 63-79.

Van de Vrugt, M., De Criminele Ordonnantiën van 1570, Zutphen 1978.

Van de Vrugt, M., Aengaende criminele saken, Deventer 1982.

Van den Bergh, L.Ph.C., Verhandeting over de oude wijze van Strafvordering, Leiden 1842.

Van Dijck, J.V., Nieuwe literatuur over een nieuw wetboek, Rechtsgeleerd Magazijn 1926, p. 49-100.

Van Dijck, J.V., Het de auditu-arrest, Nederlands Juristenblad 1927, p. 49-54. 
Van Dijck, J.V., Nog eens het de auditu-arrest, Nederlands Juristenblad 1928, p. 309-313.

Van Dijk, P. en G.J.H. van Hoof, De Europese conventie in theorie en praktijk, Nijmegen 1990 (derde druk).

Van Heijnsbergen, P., Bijdrage tot de geschiedenis van het bewijsrecht, In: Verspreide Opstellen, Amsterdam 1929, p. 227-251.

Van Heijnsbergen, P., Het inquisitoire proces, In: Verspreide Opstellen, Amsterdam 1929 , p. 323-336.

Van Veen, Th.W., Het nieuwe artikel 280 Sv: doen alsof onze neus bloedt?, Nederlands Juristenblad 1984, p. 1420-1422.

Von Brucken Fock. E.P., Anonieme getuige exit?, Nederlands Juristenblad 1990, p. 301-309.

Von Feuerbach, A.R., Betrachtungen über die Oeffentlichtkeit und Mündlichkeit der Gerechtigkeitspflege, Gießen 1821 (Band I), 1825 (Band II).

Von Meyenfeldt, C., Het gerechtelijk vooronderzoek, Nederlands Juristenblad 1988, p. 1131-1134.

Voorduin, J.C., Geschiedenis en beginselen der Nederlandse Wethoeken, Wetboek van Strafvordering. Utrecht 1939 (VI. deel), 1940 (VII. deel).

Wiersinga, H.C., Geheimzinnig of zinvol?, In: Een afzonderlijke procedure voor bekennende verdachten?, M. Hildebrandt, P.T.C. van Kampen, J.F. Nijboer, H. Wiersinga (red.), Arnhem 1993, p. 117-121.

Wolf, A., Wie let er op de anonieme infiltrant, Recht en Kritiek 1993, p. 383-398.

Zeller, H., Über Zeugen und Eideshelfer im deutschen Recht, Berlijn 1898. 


\section{Aangehaalde jurisprudentie}

\section{EHRM}

Tyrer zaak, EHRM 25 april 1978, Series A, vol. 26.

Axen zaak, EHRM 8 december 1983, Series A, vol. 72.

Öztürk zaak, EHRM 21 februari 1984, Series A, vol. 73.

Colozza zaak, EHRM 12 februari 1985, Series A, vol. 89.

Bönisch zaak, EHRM 6 mei 1985, Series A, vol. 92.

Unterpertinger zaak, EHRM 24 november 1986, Series A, vol. 110.

Ekbatani zaak, EHRM 26 mei 1988, Series A, vol. 134.

Schenk zaak, EHRM 12 juli 1988, Series A, vol. 140.

Barberà, Messegué en Jabardo zaak, EHRM 6 december 1988, Series A, vol. 146.

Kostovski zaak, EHRM 20 november 1989, Series A, vol. 166.

Windisch zaak, EHRM 27 september 1990, Series A, vol. 186.

Delta zaak, EHRM 19 december 1990, Series A, vol. 191.

Isgrò zaak, EHRM 19 februari 1991, Series A, vol. 194-A.

Asch zaak, EHRM 26 april 1991, Series A, vol. 203.

Helmers zaak, EHRM 29 oktober 1991, Series A, vol. 212-A.

Jan-Åke Andersson zaak, EHRM 29 oktober 1991, Series A, vol. 212-B.

Fejde zaak, EHRM 29 oktober 1991, Series A, vol. 212-C.

Vidal, EHRM 22 april 1992, Series A, vol. 235-B.

Lüdi zaak, 15 juni 1992, Series A, vol. 238.

Artner zaak, EHRM 28 augustus 1992, Series A, vol. 242-A.

Saïdi zaak, EHRM 20 september 1993, Series A, vol. 261-C.

Poitrimol zaak, EHRM 23 november 1993, Series A, vol. 277-A.

\section{ECRM}

Delta zaak, ECRM 12 oktober 1989, Series A, vol. 191.

Lala zaak, ECRM 4 mei 1993, NJCM-bulletin 1993, p. 811-822.

S.P. zaak, ECRM 4 mei 1993, NJCM-bulletin 1993, p. 811-822. 


\section{HR}

HR 12 april 1898, W 7117.

HR 19 mei 1913, NJ 1913, 1018.

HR 14 juni 1920, NJ 1920, 747.

HR 23 mei 1921, NJ 1921, 564.

HR 20 december 1926, NJ 1927, 85.

HR 27 april 1931, NJ 1931, 1023.

HR 17 januari 1938, NJ 1938, 709.

HR 10 januari 1978, NJ 1978, 595.

HR 13 maart 1979, NJ 1979, 268.

HR 18 november 1980, NJ 1981, 135.

HR 5 februari 1980, NJ 1980, 319.

HR 13 januari 1981, NJ 1981, 79.

HR 4 mei 1981, NJ 1982, 268.

HR 25 september 1984, NJ 1985, 426.

HR 19 maart 1985, NJ 1985, 702.

HR 12 november 1985, NJ 1986, 409.

HR 3 juni 1986, NJ 1987, 214.

HR 2 juli 1990, NJ 1990, 692.

HR 2 oktober 1990, NJ 1991, 130.

HR 16 oktober 1990, NJ 1991, 203.

HR 26 maart 1991, NJ 1991, 614.

HR 1 oktober 1991, NJ 1992, 139.

HR 1 oktober 1991, NJ 1992, 197.

HR 1 oktober 1991, NJ 1992, 198.

HR 29 oktober 1991, NJ 1992, 481.

HR 11 februari 1992, NJ 1992, 516.

HR 12 mei 1992, NJ 1992, 660.

HR 9 juni 1992, NJ 1992, 772.

HR 9 juni 1992, NJ 1992, 773.

HR 22 september 1992, NJ 1993, 85.

HR 13 oktober 1992, NJ 1993, 143.

HR 12 januari 1993, NJ 1993, 511.

HR 2 maart 1993, NJ 1993, 672.

HR 25 mei 1993, NJ 1993, 784.

HR 29 juni 1993, NJ 1993, 717.

HR 30 november 1993, NJ 1994, 247.

HR 1 februari 1994, NJB-katern 1994, p. 158, nr. 67.

HR 29 maart 1994, NJB-katern 1994, p. 232, nr. 92. 


\section{Curriculum Vitae}

Dorothé Garé werd geboren op 14 mei 1965 te Sittard. In 1983 deed zij eindexamen Atheneum A aan de Rijksscholengemeenschap Serviam te Sittard. Van 1983 tot 1988 studeerde zij Nederlands Recht met als specialisatie Strafrecht aan de Universiteit van Amsterdam. In het laatste jaar van haar studie was zij gedurende 20 uur per week als student-assistente verbonden aan het Seminarium van Hamel. Zij solliciteerde met een eigen onderzoeksplan over 'De positie van de rechter-commissaris in strafzaken' bij de Rijksuniversiteit Limburg en werd daar per 1 september 1989 aangesteld als Assistente-in-Opleiding. Ongeveer een jaar later veranderde zij, in overleg met haar promoter Prof. Mr. G.P.M.F. Mols haar dissertatie-onderwerp in 'Het onmiddellijkheidsbeginsel in het Nederlandse strafproces'. Sinds 1 april 1993 werkt zij nog steeds bij de vakgroep Strafrecht \& Criminologie aan dezelfde L'niversiteit, maar nu als universitair docente straf(proces)recht. 
Dit boek gaat over de betekenis en ratio van het onmiddellijkheidsbeginsel en de plaats van dit beginsel in het Nederlandse strafproces.

Het onmiddellijkheidsbeginsel mag zich als gevolg van de wassende stroom Europese jurisprudentie verheugen in een groeiende belangstelling van zowel rechtspraktijk als wetenschap. Tegelijkertijd ontbreekt in de Nederlandse strafprocesrechtelijke literatuur een fundamentele verhandeling over dit beginsel.

Deze studie beoogt in die leemte te voorzien.

Allereerst gaat de auteur op zoek naar de herkomst van het onmiddellijkheidsbeginsel. Aan de hand van rechtshistorisch en rechtsvergelijkend onderzoek tracht zij te komen tot een duidelijke begripsbepaling van het beginsel. Vervolgens verdiept zij zich in de vraag hoe dit uitgangspunt tot uitdrukking kwam in de opzet van het huidige Wetboek van Strafvordering (1926) en gaat zij op zoek naar de oorzaak van de verwaarlozing daarvan in ons huidige strafproces. Ook wordt uitgebreid ingegaan op de relatie tussen het onmiddellijkheidsbeginsel en het recht van iedere verdachte op een 'fair trial' zoals neergelegd in artikel 6 EVRM. Ten slotte mengt de schrijfster zich, als pleitbezorgster voor een bredere erkenning van het belang van het onmiddellijkheidsbeginsel voor een deugdelijke strafrechtspleging, in de actuele discussies rondom handhaving dan wel afschaffing van het gerechtelijk vooronderzoek, de invoering van een verkorte procedure voor bekennende verdachten en de consequenties van de Wet Getuigenbescherming. 